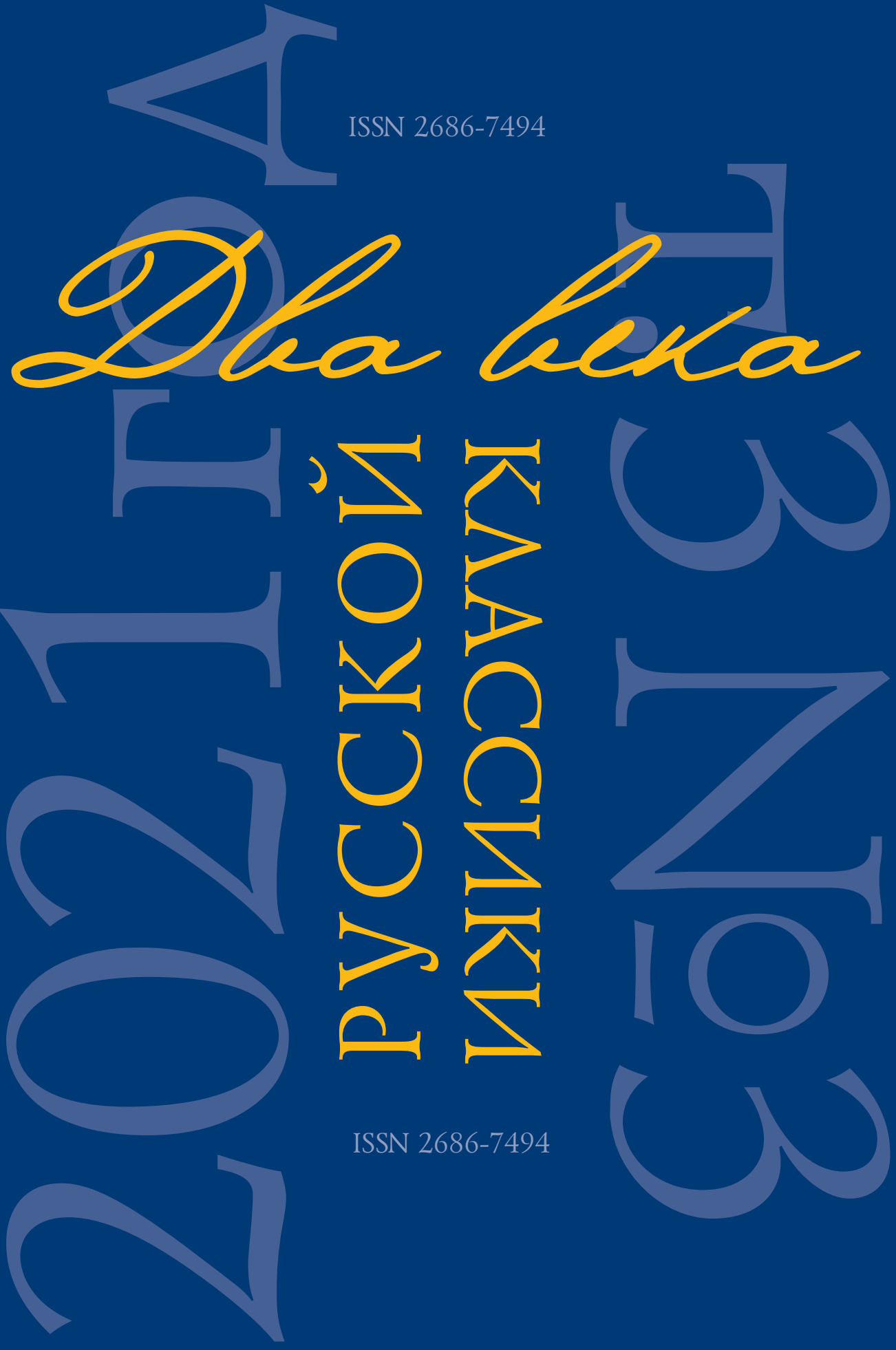


ISSN 2686-7494

\section{Два века Two centuries \\ русской классики of the Russian classics}

[Dva veka russkoi klassiki]

Научный журнал Academic Journal

Выходит с 2019 года Is published since 2019

2021 Том 3 № $3 \quad 2021$ Volume 3 No. 3

Учредитель и издатель: Founder and publisher:

мировой литературы Institute

им. А.М. Горького of World Literature

Российской of the Russian

академии наук Academy of Science

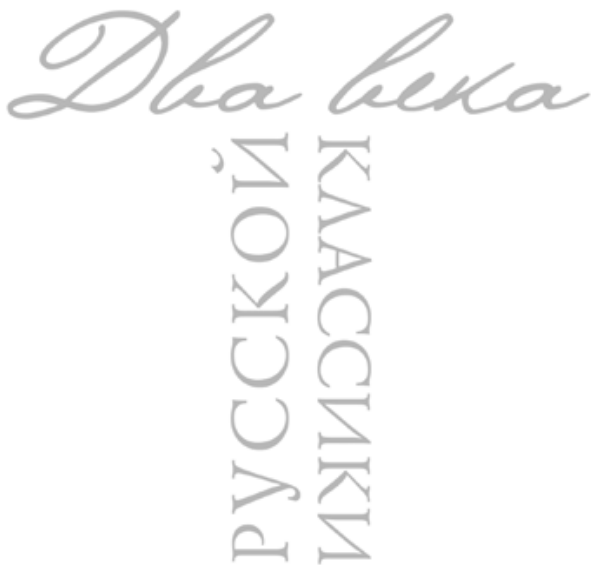




\section{Редакционная коллегия журнала «Два века русской классики»}

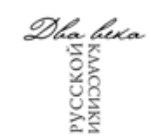

\section{Главный редактор}

Щербакова Марина Ивановна (Институт мировой литературы им. А. М. Горького

Российской академии наук, г. Москва, Россия)

Заместитель главного редактора

Виноградов Игорь Алексеевич (Институт мировой литературы им. А. М. Горького

Российской академии наук, г. Москва, Россия)

Ответственный секретарь

Андреева Валерия Геннадьевна (Институт мировой литературы им. А. М. Горького

Российской академии наук, г. Москва, Россия)

\section{Редакционная коллегия}

Гулин Александр Вадимович (Институт мировой литературы им. А. М. Горького

Российской академии наук, г. Москва, Россия), Гуминский Виктор Мирославович

(Институт мировой литературы им. А. М. Горького Российской академии наук,

г. Москва, Россия), Ивинский Александр Дмитриевич (Институт мировой литературы им. А. М. Горького Российской академии наук, г. Москва, Россия), Троицкий Всеволод Юрьевич Институт мировой литературы им. А. М. Горького Российской академии наук, г. Москва, Россия), Воропаев Владимир Алексеевич (Московский государственный университет им. М. В. Ломоносова, г. Москва, Россия), Генералова Наталья Петровна (Институт русской литературы (Пушкинский Дом) Российской академии наук, г. СанктПетербург, Россия), Захаров Владимир Николаевич (Петрозаводский государственный университет, г. Петрозаводск, Российский фонд фундаментальных исследований, г. Москва, Россия), Коровин Владимир Леонидович (Московский государственный университет им. М. В. Ломоносова, г. Москва, Россия), Лебедев Юрий Владимирович (Костромской государственный университет, г. Кострома, Россия), Михайлова Наталья Ивановна (Государственный музей А. С. Пушкина, г. Москва, Россия), Мосалева Галина Владимировна (Удмуртский государственный университет, г. Ижевск, Россия), Николаева Евгения Васильевна (Московский педагогический государственный университет, г. Москва, Россия), Николаева Светлана Юрьевна (Тверской государственный университет, г. Тверь, Россия), Федоров Алексей Владимирович (издательство «Русское слово», г. Москва, Россия), Чернышева Елена Геннадьевна (Московский педагогический государственный университет, г. Москва, Россия)

\section{Международный редакционный совет}

Авидзба Василий Шамониевич (научно-исследовательский центр «Абхазская энциклопедия», г. Сухум, Абхазия), Гини Джузеппе (Университет им. Карло Бо, г. Урбино,

Италия), Донсков Андрей Александрович (Славянская исследовательская группа при университете Оттавы, г. Оттава, Канада), Кавацца Антонелла (Университет им. Карло Бо, г. Урбино, Италия), Луцевич Людмила Федоровна (Варшавский университет, г. Варшава, Польша), Михед Павел Владимирович (Институт литературы им. Т. Шевченко Национальной академии наук Украины, г. Киев, Украина), Олджай Тюркан (Стамбульский университет, г. Стамбул, Турция), Пиотровска Иоанна (Варшавский университет, г. Варшава, Польша), Саверченко Иван Васильевич («Институт литературоведения им. Янки Купалы»

Национальной академии наук Беларуси, г. Минск, Беларусь), Рафаэль Гусман Тирадо

$$
\text { (г. Гранада, Испания) }
$$




\section{The editorial board of the journal "Two centuries of the Russian classics"}

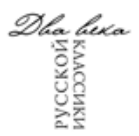

\section{Editor-in-Chief}

Marina I. Shcherbakova (A. M. Gorky Institute of World Literature of the Russian Academy of Sciences, Moscow, Russia)

Deputy Editor-in-Chief

Igor' A. Vinogradov (A. M. Gorky Institute of World Literature of the Russian Academy of Sciences, Moscow, Russia)

Managing Editor

Valeria G. Andreeva (A. M. Gorky Institute of World Literature of the Russian Academy of Sciences, Moscow, Russia)

Editorial Board

Alexander V. Gulin (A. M. Gorky Institute

of World Literature of the Russian Academy of Sciences, Moscow, Russia), Victor M. Guminsky (A. M. Gorky Institute of World Literature of the Russian Academy of Sciences, Moscow, Russia), Alexander D. Ivinsky (A. M. Gorky Institute of World Literature of the Russian Academy of Sciences, Moscow, Russia),

Vsevolod Yu. Troitsky (A. M. Gorky Institute of World Literature of the Russian Academy of Sciences, Moscow, Russia),

Vladimir A. Voropayev (Lomonosov Moscow State University, Moscow, Russia),

Natalya P. Generalova (Institute of Russian Literature (The Pushkin House) of the Russian Academy of Sciences, St. Petersburg, Russia),

Vladimir N. Zakharov (Petrozavodsk State University, Petrozavodsk, Russian Foundation for Basic Research, Moscow, Russia),

Vladimir L. Korovin (Lomonosov Moscow State University, Moscow, Russia), Yuriy V. Lebedev (Kostroma State University, Kostroma, Russia),

Natalya I. Mikhaylova (State Museum of A. S. Pushkin, Moscow, Russia), Galina V. Mosaleva (Udmurt State University, Izhevsk, Russia),

Evgenia V. Nikolaeva (Moscow Pedagogical State University, Moscow, Russia), Svetlana Yu. Nikolaeva (Tver State University, Tver, Russia),

Alexey V. Fedorov (Russian Word publishing house, Moscow, Russia),

Elena G. Chernysheva (Moscow Pedagogical State University, Moscow, Russia)

\section{International Editorial Council}

Vasily Sh. Avidzba (Abkhazian Encyclopedia Research center, Sukhum, Abkhazia), Giuseppe Genya (University of Carlo Bo, Urbino, Italy),

Andrey A. Donskov (Slavic Research Group at the University of Ottawa, Ottawa, Canada), Antonella Kavazza (University of Carlo Bo, Urbino, Italy), Lyudmila F Lutsevich (Warsaw University, Warsaw, Poland),

Pavel V. Mikhed (Institute of literature of T. Shevchenko of National Academy of Sciences of Ukraine, Kiev, Ukraine), Oldzhay Tyurkan (Istanbul University, Istanbul, Turkey), Ioann Piotrovsk (Warsaw University, Warsaw, Poland),

Ivan V. Saverchenko (Institute of Literary Criticism of Janka Kupala of National Academy of Sciences of Belarus, Minsk, Belarus), Raphael G. Tirado (Granada, Spain) 


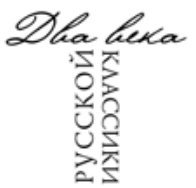

\section{Содержание}

Русская литература XVIII-ХIX столетий

6 Генералова Н. П. Нужна ли была Хорю грамота? (И. С. Тургенев и А. А. Фет: Два взгляда на проблему первоначального образования)

22 Лебедев Ю. В. У истоков диалога эпических романов в журнале «Русский вестник» (И. С. Тургенев и Б. М. Маркевич)

52 Чжу Цзяньган. The Salvation for a Nihilist: N. N. Strakhov's Ideas About A. I. Herzen

70 Едошина И. А. Александр Невский или Александр Свирский: к вопросу о небесном покровителе А. Н. Островского

84 Мосалева Г. В. Храмовая поэтика метаромана И. А. Гончарова

104 Кожевников В. А. Духовные искания Автора в первой главе романа «Евгений Онегин»

\section{Текстология}

124 Симанков В. И. Об авторстве статьи «Поездка в Грузию»

142 Белякова Е. Н. Текстологический комментарий к комедии А. Н. Островского «Богатые невесты»: к вопросу о становлении авторского замысла

160 Смирнова М. A. Autobiographical Heritage and the Fate of the Personal Archive of the Russian Comic Writer Nikolai Alexandrovich Leykin

172 Солодов Н. В. Повесть И. Г. Шадрина «Бурса»: источники и прототипы

Научная жизнь

190 Саверченко И. В. Сотрудничество двух Институтов в изучении гуманитарных взаимосвязей народов Союзного государства в ХІХ и ХХ вв.

206 Федоров А. В. Алексей Константинович Толстой как открытие 


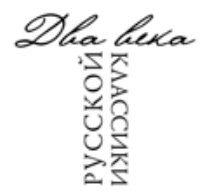

\section{Contents}

Russian Literature of the $18^{\text {th }}-19^{\text {th }}$ Centuries

6 Natalya P. Generalova. Did Khor Need Literacy? (I. S. Turgenev and A. A. Fet: Two Views on Primary Education)

22 Yuriy V. Lebedev. At the Origins of the Dialogue of Epic Novels in the Journal Russian Bulletin (I. S. Turgenev and B. M. Markevich)

52 Zhu Jiangang. The Salvation for a Nihilist: N. N. Strakhov's Ideas About A. I. Herzen

70 Irina A. Yedoshina. Alexander Nevsky or Alexander Svirsky: On A. N. Ostrovsky's Patron Saint

84 Galina V. Mosaleva. Temple-related Poetics of Goncharov's MetaNovel

104 Victor A. Kozhevnikov. Spiritual Quest of the Author in the First Chapter of the Novel Eugene Onegin

Textual Criticism

124 Vitaliy I. Simankov. Upon the Authorship of "Travel to Georgia"

142 Elena N. Belyakova. Textological Commentary to A. N. Ostrovsky's Comedy Rich Brides: on the Formation of the Author's Intention

160 Maria A. Smirnova. Autobiographical Heritage and the Fate of the Personal Archive of the Russian Comic Writer Nikolai Alexandrovich Leykin

172 Nikolay V. Solodov. The Story Bursa by I. G. Shadrin: Sources and Prototypes

Scientific Life

190 Ivan V. Saverchenko. Cooperation of Two Institutes in the Study of Humanitarian Relations of the Peoples of the Union State in the $19^{\text {th }}$ and $20^{\text {th }}$ Centuries

206 Alexey V. Fedorov. Alexey Konstantinovich Tolstoy as a Discovery 


\section{Нужна ли была Хорю грамота? (И. С. Тургенев и А. А. Фет: Два взгляда на проблему первоначального образования)}

Аннотация: В статье рассматриваются две точки зрения на проблему первоначального образования, грамотности - И. С. Тургенева и А. А. Фета. Автор описывает столкновение Тургенева и Фета, настроения и планы обоих литераторов в начале 1860 -х гг. В августе 1860 г., в ожидании отмены крепостного права находясь в Англии, на острове Уайт, Тургенев задумал и составил «Проект программы “Общества для распространения грамотности и первоначального образования”». Фет, вынужденный уйти из литературы вследствие «гонений» на «чистое искусство», приобрел 200 десятин чернозема во Мценском уезде. Не имевший собственного имения и крепостных, поэт оказался накануне отмены крепостного права в положении фермера, которому пришлось пережить бесконечные неурядицы, связанные с введением реформ во все сферы экономической и политической жизни. Его публицистика затрагивала многообразные проблемы, одной из них была проблема грамотности. Мнение Фета по данному вопросу выглядит парадоксальным. Однако он не был одинок, призывая не отождествлять грамотность, образование и воспитание, отдавая в решении проблемы предпочтение нравственному воспитанию народа. Схожую позицию занимал В. И. Даль, чье письмо издателю журнала «Русская беседа» А. И. Кошелеву анализируется в статье.

Ключевье слова: грамотность, образование, просвещение, воспитание, А. А. Фет, И. С. Тургенев, В. И. Даль, «Хорь и Калиныч», деревенские очерки, письма.

Информация об авторе: Наталья Петровна Генералова, доктор филологических наук, ведущий научный сотрудник, заведующая Группой по изданию сочинений И. С. Тургенева и А. А. Фета, Институт русской литературы (Пушкинский Дом) Российской академии наук, наб. Макарова, д. 4, 199034 г. Санкт-Петербург, Россия.

E-mail: generalovanatalia@gmail.com

Дата поступления статьи в редакцию: 08.04.2021

Дата одобрения статьи рецензентами: 16.06 .2021

Дата публикации статьи: 30.09.2021

Для иитирования: Генералова Н. П. Нужна ли была Хорю грамота? (И. С. Тургенев и А. А. Фет: Два взгляда на проблему первоначального образования) // Два века русской классики. 2021. Т. 3, № 3. С. 6-21. https://doi.org/10.22455/2686-7494-2021-33-6-21 


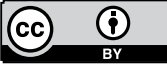

This is an open access article distributed under the Creative Commons Attribution 4.0 International (CC BY 4.0)
Dva veka russkoi klassiki, vol. 3, no. 3, 2021, pp. 6-21. ISSN 2686-7494

Two centuries of the Russian classics, vol. 3, no. 3, 2021, pp. 6-21. ISSN 2686-7494

Research Article

(C) 2021. Natalya P. Generalova

Institute of Russian Literature (Pushkin House) of the Russian Academy of Sciences

St. Petersburg, Russia

\title{
Did Khor Need Literacy? (I. S. Turgenev and A. A. Fet: Two Views on Primary Education)
}

\begin{abstract}
The article discusses two points of view on the primary education, literacy I. S. Turgenev's and A. A. Fet's. The author describes the landmark clash between Turgenev and Fet, and also shows the mood and plans of both writers in the early 1860s. In August 1860, in anticipation of the abolition of serfdom, while in England, on the Isle of Wight, Turgenev conceived and drew up a "Draft Program for the Society for the Promotion of Literacy and Primary Education". And Fet, forced to leave literature as a result of "persecution" of "pure art", acquired 200 acres of black soil in the Mtsensk district. On the eve of the abolition of serfdom, the poet, who did not have his own estate and serfs, found himself in the position of a farmer, who had to endure fully on his own experience the endless troubles associated with the introduction of reforms in all spheres of economic and political life. His journalism touched upon a variety of issues, one of which was literacy. Fet's opinion on this issue looks paradoxical. However, he was not alone, urging not to equate literacy, education and upbringing, giving preference to the moral upbringing of the people in solving the problem. A similar position was taken by V. I. Dal, whose letter to the publisher of the journal "Russkaya Beseda" A. I. Koshelev is analyzed in the article.

Keywords: literacy, education, enlightenment, upbringing, A. A. Fet, I. S. Turgenev, V. I. Dal, "Khor and Kalinych", village essays, letters.
\end{abstract}

Information about the author: Natalya P. Generalova, DSc in Philology, Leading Research Fellow, Head of the Group for the publication of works by I. S. Turgenev and A. A. Fet, Institute of Russian Literature (Pushkin House) of the Russian Academy of Sciences, nab. Makarova St. 4, 199034 St. Petersburg, Russia.

E-mail: generalovanatalia@gmail.com

Received: April 08, 2021

Approved after reviewing: June 16, 2021

Published: September 30, 2021

For citation: Generalova, N. P. "Did Khor Need Literacy? (I. S. Turgenev and A. A. Fet: Two Views on Primary Education).” Dva veka russkoi klassiki, vol. 3, no. 3, 2021, pp. 6-21. (In Russ.) https://doi.org/10.22455/2686-7494-2021-3-3-6-21 
В нашумевших в свое время очерках А. А. Фета, названных поначалу «Жизнь Степановки, или Лирическое хозяйство», а впоследствии переименованных в «Заметки о вольнонаемном труде», содержится один любопытный фрагмент, который наверняка привлек внимание И. С. Тургенева:

В запрошлом году, в сезон тетеревиной охоты, мне привелось побывать у одного из героев тургеневского рассказа «Хорь и Калиныч». Я ночевал у самого Хоря. Заинтересованный мастерским очерком поэта, я с большим вниманием всматривался в личность и домашний быт моего хозяина. Хорю теперь за восемьдесят лет, но его колоссальной фигуре и геркулесовскому сложению лета нипочем. Он сам был моим вожатым в лесу, и, следуя за ним, я устал до изнеможения; он ничего. Попал я в эту глушь как раз на Петров день. Хорь сам quasi-грамотный, хотя не научил ни детей, ни внучат тому же. У него какая-то старопечатная славянская книга, и подле нее медные круглые очки, которыми он ущемляет нос перед чтением. Надо было видеть, с каким таинственно-торжественным видом Хорь принялся за чтение вслух по складам. Очевидно, книга выводила его из обычной жизненной колеи. Это уже было не занятие, а колдовство. Старшие разошлись из избы по соседям. Оставались только ребятишки, возившиеся на грязном полу, да старуха сидела на сундуке и перебирала какие-то тряпки близ дверей в занятую мною душную, грязную, кишащую мухами и тараканами каморку.

Старуха, верно, для праздника приневолилась над пирогами и потому громогласно икала, приговаривая: «Господи Исусе Христе!» И посреди этого раздавались носовые звуки: «сту-жда-ю-ще-му-ся». Часа в три после обеда втащили буро-зеленый самовар, и Хорь прошел в мою каморку к шкапу с разбитыми стеклами. Там стояли разные бутылки с маслами и прокислыми ягодами, разнокалиберные чашки, помадная банка со скипидаром, а рядом с нею из замазанной синей бумаги выглядывали крупные 
листья чаю. Тут же, на другой бумажке, лежал кусок сахару, до невероятия засиженный мухами.

- Не хочешь ли, старик, я тебе отсыплю свеженького чайку?

- Пожалуйте. Да ведь нам чай надолго, - прибавил Хорь. - Пьем мы его по праздникам. Попьем, попьем да опять на бумаге высушим. Вот он и надолго хватит [Фет 2007: 159-160].

Можно гадать, какую старопечатную книгу читал Хорь, скорее всего, это было Евангелие на старославянском языке. Ср.: «Во всем скорбяще, не стужающе си» (2 Кор. 4: 8), т. е. «Мы отовсюду притесняемы, но не стеснены». Правда, в слове, которое произносит Хорь, есть ошибка, поскольку буквы «д» в «стужающе» нет, как нет возвратной формы глагола «стужати» (теснить, стеснять, досаждать). Возможно, Фет воспроизвел неграмотное чтение Хоря, но не исключено, что в текст вкралась опечатка.

Любопытно отметить, что тургеневский Хорь грамотой не владел, в отличие от Калиныча, которому «грамота далась» легко, к тому же «у него и пчелы отродясь не мерли», как парадоксально выразился сам Хорь. На вопрос, выучил ли он детей грамоте, тургеневский Хорь признался, что только один из его сыновей, Федя, знает грамоте. Выходит, за то время, что прошло ко времени визита к нему Фета, Хорь все же кое-как овладел грамотой, хотя и читал по складам. А по свидетельству И. А. Баталина, как увидим далее, он читал не только Евангелие, но и рассказ Тургенева «Хорь и Калиныч» [Баталин].

Сюжет с посещением тургеневского Хоря, конечно, появился в очерках Фета не случайно. Попробуем разобраться, что хотел сказать своим рассказом автор. Но прежде отметим, что само по себе описание этого визита дает много фактических сведений о судьбе знаменитого тургеневского героя. Его выразительный портрет представляет нам человека, по-прежнему уверенного в себе, обладающего недюжинной силой, несмотря на солидный возраст. Он по мере возможностей гостеприимен и, отселившись от общины, не изменил своим привычкам. Уже следующие поколения подрастают в большой семье.

Напомним, что вошедший в историю Хорь стал героем еще одного очерка, принадлежавшего перу Ивана Андреевича Баталина (1844-1918), довольно известного в свое время журналиста, сотруд- 
ничавшего в нескольких столичных периодических изданиях. В издававшейся им газете «Утро», где он вел ежедневную рубрику «Утренние беседы», Баталин, сам уроженец Калужской губернии, в 1897 г. опубликовал очерк «50-летие “Хоря и Калиныча"» и сообщил, что был знаком с Хорем, которого представил как «мощного, умного, высокого роста и необыкновенно радушного» старика. «Так как он был грамотный, - писал Баталин, - то Тургенев прислал ему свой рассказ; старик с гордостью перечитывал его каждому гостю» [Баталин]. К сожалению, Баталин не указал точное время своего знакомства с Хорем, но учитывая, что в 1859 г., когда тургеневского героя посетил Фет, журналисту было всего 15 лет, знакомство это состоялось еще позднее, по крайней мере лет через пять или более того.

Однако картина, нарисованная Баталиным, разительно отличается от той, что представил в своем очерке Фет. Впрочем, радушие присуще и фетовскому Хорю. Другое дело - результат его хозяйственной деятельности, которой так восхищался Тургенев в рассказе «Хорь и Калиныч». Напомним всем известные тургеневские строки:

Мы вошли в избу. Ни одна суздальская картина не залепляла чистых бревенчатых стен; в углу, перед тяжелым образом в серебряном окладе, теплилась лампадка; липовый стол недавно был выскоблен и вымыт; между бревнами и по косякам окон не скиталось резвых прусаков, не скрывалось задумчивых тараканов [Тургенев. Соч. 3: 9].

И дети у Хоря были все как на подбор, и квас хорош, и ломоть пшеничного хлеба огромен, и пегий жеребец сыт и силен. Даже отсутствующие прусаки были всего лишь резвы, а тараканы так и вовсе задумчивы. Недаром у чуткого В. П. Боткина с языка сорвалось слово «идиллия». Сколько было в этой идиллии правды, а сколько художественного вымысла, сказать теперь сложно, однако что-то должно было произойти в семье Хоря, если через пятнадцать-двадцать лет после Тургенева оказалось, что его благополучие было скорее мнимым, чем подлинным. Как надо было страдать за свой народ, как сильно желать ему добра, чтобы нарисовать картину, которая вошла не только в сознание читателей, но и сделала имена героев рассказа нарицательными! Попутно заметим, что упомянутые Тургеневым «суздальские картины», очень разнообразные по тематике, 
были в действительности лубками, широко распространившимися по всей России. Наряду с иконами они встречались почти в каждой крестьянской избе $\mathrm{e}^{1}$. По-видимому, Тургеневу такая «живопись» была не по вкусу.

Кто-то может спросить: а не перегнул ли палку Фет, будто нарочно выбрав самые неприглядные стороны житья-бытья легендарного Хоря? Почему столь идиллически описанное Тургеневым хозяйство оказалось спустя два десятка лет в подобном запустении? На эти вопросы мы пока не можем ответить. Возможно, Хорю все же пришлось откупиться от своего помещика и попасть, чего он так опасался, в беспощадные лапы чиновников. Нас больше интересует другое.

История с визитом к Хорю включена Фетом в главу IX «Заметок о вольнонаемном труде», напечатанную в мартовском номере «Русского вестника» за 1862 г., написана же она была в конце 1861 г. и называлась «Песня». В ней Фет действительно рассуждал о русской народной песне и о проникновении в крестьянскую среду городского романса. Здесь вновь незримо появляются герои еще одного тургеневского рассказа из «Записок охотника».

Всем известна привычка русского ремесленника петь во время работы. Пахарь не поет, зато плотники, каменщики, штукатуры - почти неумолкающие певцы. Последнее слово напоминает очаровательный рассказ Тургенева: но я не был так счастлив, чтобы встретить что-нибудь похожее на описанных им певцов. Много переслушал я русских песен, но никогда не слыхал ничего сколько-нибудь похожего на музыку [Фет 2007: 156].

Заключалось главка следующим рассуждением:

Дай Бог, чтобы русские крестьяне поскорее $<\ldots>$ почувствовали потребность затянуть новую песню. Эта потребность сделает им трубы,

1 Правда, к 1850-м гг. мода на лубок стала уходить из крестьянского быта. «Картинки суздальской гравировки украшают стены в горницах $<\ldots>$, писал сибирский литератор и краевед В. П. Паршин. - Суздальские картинки ныне стали в Сибири очень редки и только на Барабинской степи еще можно полюбоваться - гисториями в лицах: о носе и сильном морозе, о Фоме музыканте и Еремее плясуне, козе в сарафане и проч.» [Паршин: 103]. 
вычистит избу, даст человеческие постели, облагородит семейные отношения, облегчит горькую судьбу бабы <..> явятся новые потребности, явится и возможность удовлетворить их. <..> Нравственное развитие не гвоздь какой-нибудь, который можно произвольно забить в народ, как в стену. Оно уживается только с материяльным довольством. А нельзя отрицать заметного стремления русского крестьянина к прогрессу в последние 25 или 30 лет <...> [Фет 2007: 157].

После довольно подробных рассуждений о проникновении в крестьянский быт новых веяний, даже по части одежды, Фет заключал: «Выше я радовался возникающим в народе потребностям некоторых удобств. Но эти факты действительно отрадны только там, где они являются выражением более высокого уровня жизни» [Фет 2007: 159]. Значит, последующее затем описание житья грамотея Хоря должно было продемонстрировать противоположный пример. Не случайно оно завершалось безотрадным выводом: «Кто после этого скажет, чтобы грамотность и чай были в семье Хоря действительными потребностями?» [Фет 2007: 160].

Комическое чаепитие одних и тех же подсушенных листов чая оставим в стороне. Но неужели Фет в самом деле считал грамотность излишней в крестьянской среде? Ответ на этот вопрос не так прост, как может показаться на первый взгляд.

Это был первый год самостоятельного хозяйствования Фета в приобретенной летом 1860 г. Степановке. Вынужденный уйти из литературы вследствие «гонений» на «чистое искусство», Фет решил вопрос со своим «трудоустройством» с присущей ему прямотой: он приобрел 200 десятин чернозема во Мценском уезде с недостроенным домом и активно взялся за обустройство своего нового жилища. Не имевший собственного имения и крепостных, поэт оказался накануне отмены крепостного права в положении фермера, которому в полной мере пришлось пережить на собственном опыте бесконечные неурядицы, связанные с введением реформ во все сферы экономической и политической жизни. Его обширная по объему публицистика затрагивала многообразные проблемы, возникавшие в ходе реформ. Одной из них была проблема грамотности.

Напомним, что в августе 1860 г., в ожидании долгожданного события - отмены крепостного права - находясь в Англии, на острове Уайт, 
Тургенев задумал и составил «Проект программы “Общества для распространения грамотности и первоначального образования”». К этому проекту прилагалось циркулярное письмо, разосланное ряду адресатов. Объявляя Общество помощником правительства в деле освобождения людей от «другого рабства - рабства невежества», Тургенев предлагал широкую программу обустройства школ, кабинетов для чтения, выпуска учебной литературы и т. д. [Тургенев. Соч. 12: 359-366]. Активное участие в подготовке этих документов принял верный друг Тургенева П. В. Анненков. Предполагалось широкое обсуждение Проекта, причем свои замечания и добавления следовало направлять по двум адресам - Тургеневу (в Париж, до востребования) и Анненкову (в Петербург). Работа по распространению Проекта и циркулярного письма закипела. Тургенев привлекал к переписыванию всех своих знакомых - от графини Елизаветы Егоровны Ламберт до Марии Александровны Маркович (Марко Вовчок). Результат этой деятельности был, однако, не слишком значителен. Идея, что называется, витала в воздухе: в апреле 1861 г. состоялось первое заседание Комитета грамотности, учрежденного при Вольном экономическом обществе. Задачи этого Комитета в основном совпали с теми, что выдвигал Тургенев. Не было ничего удивительного и в том, что через год, 12 октября 1861 г., Тургенев стал членом этого Комитета [Летопись: 310].

Знал ли Фет о замысле Тургенева? Конечно, знал, ведь в это время оба страстных спорщика активно общались и переписывались. 31 августа (12 октября) 1860 г. Тургенев писал Фету из Парижа по поводу своего проекта: «Я послал несколько копий этого проекта в Россию и буду продолжать посылать. Пошлю и Вам. Прочтите и скажите свое мнение. Дело, кажется, хорошее - и практически задумано. <..> Напишите Ваше мнение - и, буде случится, возражения» [Тургенев, Письма 4: 234].

Комментируя это письмо, А. И. Батюто отметил: «Мнение Фета об этом документе неизвестно» [Тургенев. Письма 4: 581]. Для такого заключения были, казалось, все основания. Действительно, ответ Фета (а он, разумеется, был) до нас не дошел. Публикуя письмо в первом томе «Моих воспоминаний», Фет также не оставил никаких комментариев. Нет упоминаний об этом сюжете и в последующих сохранившихся письмах Тургенева. И все же, на наш взгляд, можно с уверенностью утверждать, что Фет отказался читать составленный Тургеневым 
проект или очевидным образом высказался не в его пользу. Появление Хоря на страницах «Записок о вольнонаемном труде» является несомненным тому подтверждением.

Но есть еще одно доказательство сказанного. Это письмо Фета к М. М. Ледерле, написанное за год до смерти и не так давно введенное в научный оборот [Генералова: 62-64]. В первых числах июня 1891 г. известный в свое время издатель и книгопродавец Михаил Михайлович Ледерле, задумавший, по примеру европейских авторов, составить своеобразный опросник, призванный представить список рекомендованных книг для чтения, разослал 2000 экземпляров циркулярного письма, в котором обратился к известным представителям культуры и науки с просьбой ответить на ряд вопросов. И хотя из 2000 предполагаемых ответных писем Ледерле получил лишь 86 «отрицательных и положительных ответов», книга все-таки вышла в свет, хотя и гораздо позже, чем рассчитывал издатель. Называлась она «Мнения русских людей о лучших книгах для чтения» [Мнения]. Получил такое циркулярное письмо и Фет. Его ответ был частично воспроизведен в книге, однако важнейшие пункты его письма, позволяющие отнести ответ Фета скорее к «отрицательным», нежели к «положительным», были Ледерле опущены. Вот что писал Фет:

Смущают меня понятия с одной стороны грамотности, а с другой образования, из которых первое представляет только самую низшую ступень беспредельной лестницы второго. Так как первое относится ко всей массе народонаселения, то не могу умолчать, что, придерживаясь изречения «primum edere, deinde philosophari» (т. е. «сначала пища, потом философия». - H. Г.), считаю, что надо бы в течение 30 лет со дня освобождения масс заботиться хотя бы о сохранении того нравственного и материального благосостояния, которым они пользовались при прежнем порядке, тем более что сама реформа нашла название: улучшение быта крестьян. Между тем мы сделали все, чтобы внести в народные массы полное неуважение к законному порядку и нравственности: воспользоваться самыми низкими народными инстинктами для близоруких фискальных целей.

Итак, главное, на чем зиждется искомое благо народа, болезненно надломлено, причем упущено из виду, что человек, поднявшийся в материальном отношении над уровнем других, тем самым вынуждается к грамотности и тому роду образования, в котором чует ближайшее нравственное 
благо. Можно допустить предложение со стороны интеллигенции народу умственной пищи на тех же экономических основаниях, на каких в городах предлагается рядом с черным хлебом и белый, но навязывать бедняку, который не в состоянии купить и черного хлеба, во что бы то ни стало белый, хотя и гибельно в экономическом отношении, но далеко не настолько, насколько вредоносно искусственное распространение грамотности, тем более в видах проводника так называемых последних слов науки. <...> Нельзя же в самом деле серьезно говорить о последних словах науки. Наука по своей бесконечности последних слов иметь не может, и нередко вчерашнее последнее слово оказывается сегодня решительным вздором [Генералова: 63].

Далее Фет излагал свои мысли о классическом образовании, не раз высказанные им в разных статьях и частной переписке. Именно этот фрагмент письма Ледерле воспроизвел в своей подборке. Но нас интересует в данном случае другое, а именно отношение Фета к вопросу о первоначальной грамотности.

Таким образом, противопоставляя «беспредельную лестницу» образования его первой ступени - грамотности, распространением которой были озабочены передовые умы, Фет спустя 35 лет возвращался к спору, начатому еще в 1856 г. публикацией письма В. И. Даля к А. И. Кошелеву, в котором утверждалось, что «грамота сама по себе ничему не вразумит крестьянина; она скорее собьет его с толку, а не просветит» [Даль: 3]. Откликаясь на призыв выступить на страницах вновь образованного славянофильского журнала и надеясь, что слова его не будут «выворачивать наизнанку», автор знаменитого Словаря живого великорусского языка, над которым он в это время трудился, подробно объяснил свою позицию. «В противуборстве западному приливу и волнению, кажется, не может быть иного смысла, как требование, во-первых, принимать образованность и просвещение в добром направлении его, а не в дурном - (можно быть умным и ученым негодяем), - и, во-вторых, принимать его не бессознательно, а применяя и приурочивая к своей почве, следовательно, отвергая или изменяя все то, что нам негоже, что не может быть приурочено» [Даль: 1]. В обстановке горячих обсуждений будущей реформы, чрезвычайного оживления русской журналистики Даль счел необходимым предупредить спорящих об опасностях, грозящих всему укладу русской жизни вследствие заимствованных с Запада учений и бездумного перенима- 
ния чужого опыта. В статье Даля рассматривались различные стороны проблемы, но начал он с уточнения, что же следует понимать под просвещением.

Нож и топор - вещи необходимые, - писал Даль, - а между тем сколько было зла от ножа и топора? Пример этот крут; чтобы показать степени в этом деле, примените то же рассуждение к пороху, к пару, к самой грамоте, и вы конечно согласитесь, что для доброго, полезного приложения изобретений этих к делу нужно быть приуготовленным, приспособленным; нужно пройти через низшие ступени к высшим, нужно понять опасность обращения с таким товаром и не только умом и сердцем желать добра, но и не заблуждаться насчет последствий; а заблуждение это именно тогда вероятно, когда мы слепо и бессознательно подражаем [Даль: 2].

«Но разве просвещение и грамотность одно и то же?» - восклицал далее автор письма в «Русскую беседу» и отвечал: «Грамота только средство, которое можно употребить на пользу просвещения, и на противное тому - на затмение» [Даль: 3].

Прошу не принимать слов моих в таком смысле, - писал Даль, - будто я гоню грамоту; нет, я хочу только убедить вас, что грамота не есть просвещение, а относится к одному внешнему образованию, и поэтому не может быть сущностию забот наших для образования простолюдина. Придавать лоск прежде отделки вещи нельзя, разве для того только, чтобы обмануть наружным видом ее. Слово грамотей уже частенько слышится в бранном смысле как равносильное плуту, даже мошеннику, и в этом случае именно подразумевается, что грамотность у этого человека заняла место совести [Даль: 4].

Приводя примеры, когда тот или иной мужик пытался использовать знание законов в свою пользу, будучи не прав, Даль красочно описывает несколько случаев, когда правда восстанавливалась согласно исконным народным обычаям, а не письменным указам. Среди них приведен и такой:

А случалось ли вам когда-нибудь видеть, как веритель, взяв в руки нож и бирку неплательщика, сурово грозит ему: «Эй, срежу, вот ей, ей, срежу», 
и как отчаянный должник кланяется в пояс и, сознавая вину свою, упрашивает заимодавца потерпеть на нем, приговаривая: «Бог не без милости, отдам, не душа лжет, мошна»; а я видел это своими глазами в одной из низовых уральских станиц. Коли безнадежный долг срезан с бирки, то его уже нет; но должник обесчещен навек <...> срезанную бирку такого-то кажут на весь мир, и делу конец. Это мирская опала, от которой и бессовестный сохнет [Даль: 5].

Любопытно, что вторая глава последнего тома мемуаров Фета «Ранние годы моей жизни» начинается с воспоминаний о том, как он учился грамоте. Попутно он рассуждает о том, кто обучал грамоте в русской деревне и кому более пристало этим заниматься:

Во время моего детства Россия, не забывшая векового прошлого, знала один источник наук и грамотности - духовенство; и желающие зажечь свой светильник вынуждены были обращаться туда же [Фет 1893: 15].

Судя по всему, отчим Фета Афанасий Неофитович Шеншин, которого будущий поэт называл отцом, придерживался домостроевских правил в деле образования и не спешил открывать школы в своем имении:

По отношению образования крепостных людей отец всю жизнь неизменно держался правила: всякий крестьянин или дворовый, по достижении сыном соответственных лет, обязан был испросить позволения отдать его в обучение известному ремеслу, и бывший ученик обязан был принести барину на показ собственного изделия: овчину, рукавицы, подкову, полушубок или валенки, и только в случае одобрения работы отцу дозволялось просить о женитьбе малого. И вот одна из главных причин сравнительного благосостояния отцовских крестьян. Что же касается до грамотности, то желающим предоставлялось отдавать мальчика к попу <...> [Фет 1893: 15].

Но далее Фет сообщает о том, что отец «никогда не проверял успехов школьников», и объясняет причину столь странного отношения к учебе: «...так как все счеты в заглазных имениях велись неграмотными старостами по биркам, а общие счеты отец сводил собственноручно, для чего нередко просиживал ночи, чем немало гордился, называя это своими мозолями» [Фет 1893: 15-16]. 
Счет по биркам был своеобразной формой фиксации имущественных отношений еще в средние века, своего рода векселями, применявшейся как в Западной Европе, так и в России. Изначально биркой (от шведск. björk - береза) называли обструганную с одной стороны палочку, плашку из березы или другой мягкой древесины, на которую наносились зарубки, после чего плашка расщеплялась и оставалась на руках тех, кто совершал сделку (должником и кредитором, поставщиком и плательщиком, хозяином и работником и т. п.). В данном случае старосты таким образом учитывали отработанные крестьянами в пользу помещика дни или произведенные мастеровыми изделия. Подробно описал счет «по бирками» орловский историк Г. М. Пясецкий:

Орловское купечество, не учась грамоте, не имело у себя никаких долговых записей или расписок; а если кто у кого делал забор, то метили на бирку. Это была небольшая деревянная палочка, толщиною в палец, с одной стороны обтесанная. На этой палочке, или бирке, поперек плоской стороны делались различные зарубки - прямые, косые и крестовидные; прямые черточки означали единицы, косые - десятки, а кресты - сотни. По начертании таких знаков палочка разделялась на две половинки, из которых одну вместо расписки брал себе кредитор, а другую должник или приемщик. Если должник медлил расчетом, то купец, при свидании, считал себя вправе пристращать его словами: «Отдашь ты мне долг или нет? А то срежу!» - т. е. срежу знаки, которые были на бирке. При этих словах должник падал купцу в ноги и просил повременить еще. Срезание бирки без уплаты долга считалось за великое бесчестье; такому человеку ни у кого более нет доверия. Если же и после этого долг не уплачивался, тогда кредитор дожидал воскресного или праздничного дня, чтобы учинить полный расчет с своим должником. Теперь, по выходе с обедни, кредитор всенародно снимает с него шляпу, и тот остается уже самым негодным человеком в городе [Пясецкий: 67$]^{1}$.

Фет не скрывает своего восхищения надежным способом учета товарно-денежных отношений. Правда, отмечает, что среди молодой дворни новоселковского барина почти все были грамотными, хотя не отказывает себе в удовольствии иронизировать по поводу глубины

${ }^{1}$ За эту ссылку приношу сердечную благодарность Е. Н. Ашихминой. 
приобретенных дворовыми знаний, рассказав о случае с буфетчиком Павлом Тимофеевичем, попавшим «в силу своей грамотности» при распродаже дубового леса в приказчики и собственноручно записывавшим расход дубов и приход денег:

Ему не только хорошо были известны буквы и цифры, но и знаки препинания, постоянно выручавшие его из беды. Так, когда в слове: «получено» - ножка «л» слишком близко подвигалась под брюшко «о», и читающий мог принять это сочетание за «а», - на выручку являлась запятая, указывающая, что это две буквы, а не одна [Фет 1893: 16].

В письме Даля и деревенских очерках Фета встречается немало и других перекличек, о которых следовало бы говорить особо.

Откликаясь на полемику, возникшую по вопросу о первоначальной грамотности, Фет еще в 1863 г. писал в очерке «Из деревни»:

Кого же было бы всего желательнее видеть теперь народным воспитателем? Бесспорно, священника, пока не явятся специальные педагоги, воспитанные в духе христианского смирения и любви [Фет 2007: 252].

И там же:

Христианство является, бесспорно, высшим выражением человеческой нравственности и основано на трех главных деятелях: вере, надежде и любви. Первыми двумя оно обладает наравне с прочими религиями. Нет религии без веры и надежды; зато любовь - исключительный дар христианства, и только ею Галилеянин победил весь мир. Излишне говорить, что вера, надежда и любовь свойственны душе человека. Христианство и не могло бы быть таким могучим двигателем, опираясь на несуществующее. И важна не та любовь, которая, как связующее начало, разлита во всей природе, а то духовное начало, которое составляет исключительный дар христианского воспитания [Фет 2007: 244].

Таким образом, Фет предлагал не отделять вопрос о грамотности от вопросов образования и воспитания, но в то же время не смешивать этих понятий. Думается, что ему, столкнувшемуся в первоначальный период своей хозяйственной деятельности с целым рядом насущных 
вопросов, которые предстояло решать в пореформенное время, идея Тургенева не показалась первоочередной, и он прямо сказал ему об этом.

Следует, пожалуй, добавить, что в упомянутом циркулярном письме Ледерле речь о первоначальной грамоте даже не заходила. К тому же к 1890-м гг. количество начальных школ, в том числе и церковно-приходских, было весьма значительным и вряд ли могло вызвать возражения. Затронутый Ледерле вопрос побудил Фета вернуться к давнему спору и еще раз сформулировать ответ на него. Следует добавить: свое циркулярное письмо Ледерле с гордостью подписал: «Искренне Вас уважающий М. Ледерле, член Совета С.-Пб. Комитета грамотности» (курсив мой. - Н. Г.) [Генералова: 60]. Того самого Комитета грамотности, членом которого в октябре 1861 г. стал Тургенев.

\section{Список литературы \\ Источники}

Баталин И. А. Утро. 1897. № 16. 18 января.

Даль В. И. Письмо к издателю А. И. Кошелеву // Русская беседа. 1856. Т. 3. Отд. V: Смесь. С. 1-16.

Мнения русских людей о лучших книгах для чтения. СПб.: Изд-е М. М. Ледерле и К ${ }^{\circ}, 1895.192$ с.

[Паршин В. П.] Описание пути от Иркутска до Москвы, составленное 1849 г. В. П. М.: Тип. Александра Семена, 1851. 230 с.

Тургенев И. С. Полн. собр. соч.: в 30 т. Соч.: в 12 т. М.: Наука, 1978-1986; Письма: в 18 т. М.: Наука, 1982-.

Фет А. А. Ранние годы моей жизни. М.: Тов-во тип. А. И. Мамонтова, 1893. $548 \mathrm{c}$.

Фет А. А. Собр. соч.: в 20 т. СПб.: Фолио-Пресс - Атон, 2007. Т. 4.558 с.

\section{Исследования}

Генералова Н. П. А. А. Фет о книге и круге чтения (Письмо к М. М. Ледерле от 25 июня 1891 года) // Русская литература. 2020. № 4. C. 55-64. DOI: 10.31860/01316095-2020-4-55-64

Летопись жизни и творчества И. С. Тургенева (1859-1862) / отв. ред. Н. П. Генералова. СПб.: Росток, 2018. 680 с.

Пясеикий Г. М. Забытая история Орла. Орел: Изд-во Орлов. гос. телерадиокомпании, 1993. $251 \mathrm{c}$. 


\section{References}

Generalova, N. P. "A. A. Fet o knige i kruge chteniia (Pis'mo k M. M. Lederle ot 25 iiunia 1891 goda)" ["A. A. Fet on Book and Readership (Letter to M. M. Lederle, June 25, 1891)"]. Russkaia literature, no 4, 2020, pp. 55-64. DOI: 10.31860/0131-6095-20204-55-64 (In Russ.)

Generalova, N. P., editor. Letopis' zhizni i tvorchestva I. S. Turgeneva (1859-1862) [Chronicle of I. S. Turgenev's Life and Works (1859-1862)]. St. Petersburg, Rostok Publ., 2018. 680 p. (In Russ.)

Piasetskii, G. M. Zabytaia istoriia Orla [Forgotten History of Orel]. Orel, Izdatel'stvo Orlovskoi gosudarstvennoi teleradiokompanii Publ., 1993. 251 p. (In Russ.) 


\section{У истоков диалога эпических романов в журнале «Русский вестник» (И. С. Тургенев и Б. М. Маркевич)}

Исследование выполнено при финансовой поддержке РФФИ в рамках научного проекта № 20-012-00102

Аннотация: В статье рассматривается возникновение личных и творческих связей И. С. Тургенева с Б. М. Маркевичем. Доказывается, что романы Маркевича и других членов «плеяды московских писателей», сотрудников «Русского вестника», создавались с установкой на художественную полемичность. Рассматриваются связи и противостояния в мировоззрении Тургенева и Маркевича, разделявшего идеологические установки М. Н. Каткова. Маркевич выступал за государственную целостность страны, в дополнение к тургеневским «нигилистам» и «лишним людям» он избирал в качестве литературных героев патриотически настроенных дворян. В романе «Типы прошлого», вышедшем в свет в «Русском вестнике» через четыре месяца после публикации романа «Дым», Маркевич противопоставил Ирине и Литвинову «добродетельную матрону» и «примерных граждан». Маркевич полемизирует с тургеневским культом любви как стихийной страсти, отстаивая православно-христианские ценности. Отзыв Тургенева на этот роман затерян, но по ответному письму Маркевича видно, что Тургенев подверг его суровой критике. В романе «Новь» в лице Нежданова Тургенев дал полемический ответ Маркевичу, по-своему разрешив этот конфликт в пользу политических убеждений героя.

Ключевые слова: прием «перепева», диалоги художественных миров, мировоззренческие сближения, идейные противостояния, сепаратизм, государственная целостность, нигилизм, «низы» и «верхи» общества.

Информация об авторе: Юрий Владимирович Лебедев, доктор филологических наук, профессор, заслуженный деятель науки РФ, Костромской государственный университет, ул. Дзержинского, д. 17, 156005 г. Кострома, Россия.

E-mail: y.v.lebedev@yandex.ru

Дата поступления статьи в редакиию: 26.04 .2021

Дата одобрения статьи рецензентами: 19.07.2021

Дата публикации статьи: 30.09.2021

Для иитирования: Лебедев Ю. В. У истоков диалога эпических романов в журнале «Русский вестник» (И. С. Тургенев и Б. М. Маркевич) // Два века русской классики. 2021. T. 3, № 3. С. 22-51. https://doi.org/10.22455/2686-7494-2021-3-3-22-51 


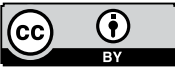

This is an open access article distributed under the Creative Commons Attribution

4.0 International (CC BY 4.0)
Dva veka russkoi klassiki, vol. 3, no. 3, 2021, pp. 22-51. ISSN 2686-7494

Two centuries of the Russian classics, vol. 3, no. 3, 2021, pp. 22-51. ISSN 2686-7494

Research Article

(C) 2021. Yuriy V. Lebedev

Kostroma State University

Kostroma, Russia

\section{At the Origins of the Dialogue of Epic Novels in the Journal Russian Bulletin (I. S. Turgenev and B. M. Markevich)}

Acknowledgments: The reported study was funded by Russian Foundation for Basic Research (RFBR), project number 20-012-00102.

Abstract: The article examines the emergence of personal and then creative ties between I. S. Turgenev and B. M. Markevich. It is proved that the novels of Markevich and other members of the "constellation of Moscow writers", employees of the Russian Bulletin, were created with an attitude towards artistic polemic. The article examines connections and confrontations in the worldview of Turgenev and Markevich, who shared the ideological guidelines of the editor of the "Russian Bulletin" M. N. Katkov. Markevich advocated the state integrity of the country, in addition to Turgenev's "nihilists" and "superfluous people", he chose patriotic nobles as literary heroes. In the novel Types of the Past, published in the Russian Bulletin four months after the publication of the novel Smoke, Markevich contrasted Irina and Litvinov with "a virtuous matron" and "exemplary citizens". Markevich argues with Turgenev's cult of love as a spontaneous passion, defending Orthodox Christian values. Turgenev's response to this novel is lost, but Markevich's reply letter shows that Turgenev subjected him to severe criticism. In the novel Virgin Soil in the person of Nezhdanov, Turgenev gave a polemical answer to Markevich, resolving this conflict in his own way in favor of the hero's political convictions.

Keywords: reception of "rehash", dialogues of artistic worlds, worldview convergence, ideological confrontation, separatism, state integrity, nihilism, "lower classes" and "upper classes" of society.

Information about the author: Yuriy V. Lebedev, DSc in Philology, Professor, Honored Scientist of the Russian Federation, Kostroma State University, Dzerzhinsky St. 17, 156005 Kostroma, Russia.

E-mail: y.v.lebedev@yandex.ru

Received: April 26, 2021

Approved after reviewing: July 19, 2021

Published: September 30, 2021

For citation: Lebedev, Yu. V. "At the Origins of the Dialogue of Epic Novels in the Journal Russian Bulletin (I. S. Turgenev and B. M. Markevich)." Dva veka russkoi klassiki, vol. 3, no. 3, 2021, pp. 22-51. (In Russ.) https://doi.org/10.22455/2686-7494-2021-3-3-22-51 
Б. М. Маркевич вместе с В. Г. Авсеенко, графом Е. А. Салиасом, Д. В. Аверкиевым, К. Ф. Головиным-Орловским принадлежал к «молодой плеяде московских писателей», которых М. Н. Катков специально привлекал к сотрудничеству в журнале «Русский вестник». Их романы вступали в диалог с произведениями И. С. Тургенева, Л. Н. Толстого, Ф. М. Достоевского, Н. С. Лескова и других писателей первого ряда, публиковавшихся в этом журнале.

Э. Г. Гайнцева считала, что «притяжение “плеяды” к этим писателям выражалось, прежде всего, в откровенном и грубом подражании, в прямых заимствованиях $<\ldots>$ композиционных, образных и стилистических форм». «Творческая позиция писателей “плеяды” - позиция эпигонов, обреченных вечно носить одежды с чужого плеча», «эклектичность определяет характерные приметы их творчества - компилятивность, цитатность, стилистическую пестроту» [Гайнцева: 146-149].

Исследовательница подмечала характерные особенности прозы этих писателей, но, как нам кажется, давала им слишком неадекватную оценку. Дело в том, что романы Маркевича и других членов «плеяды» как раз и создавались с установкой на художественную полемичность, которая не связана ни с эпигонством, ни с компилятивностью. Подключаясь эстетически к художественным мирам Тургенева или Толстого, эти писатели вносили с помощью «перепевов» свои штрихи в их осмысление, в чем-то обогащая, в чем-то полемически трансформируя чуждые им художественные миры. Как справедливо отмечает В. Г. Андреева, «в 1860-1880-е годы между русскими романистами разворачивается уникальный полилог, репликами которого являются художественные произведения (романы)...» [Андреева: 382].

Начало спора Маркевича с Тургеневым связано с публикацией в «Русском вестнике» (1867, № 3) романа «Дым». Через четыре месяца в № 8-12 этого журнала появляется полемический по отношению к «Дыму» роман Маркевича «Типы прошлого», подписанный псевдони- 
мом «Б. Лесницкий». Предыстория этой полемики заслуживает особого внимания.

История дружеских и творческих связей Тургенева с Маркевичем достаточно противоречива и драматична. Летом 1862 г. из Лондона в Петербург отправился П. А. Ветошников с большим количеством нелегальных изданий и писем, адресованных Герценом, Бакуниным, Огаревым и В. И. Кельсиевым друзьям-единомышленникам в России. На границе Ветошникова арестовали, и в руках III отделения оказались письма Бакунина, в которых упоминалось имя Тургенева, обещавшего Бакунину денежную помощь. В других письмах и инструкциях Тургенев представал как близкий и доверенный Герцену человек, через которого поддерживались связи «лондонских эмигрантов» с Россией и черпались сведения для обличения правительственных верхов в «Колоколе». Дело принимало неприятный для Тургенева оборот. 22 января 1863 г. ему вручили официальный вызов в Петербург.

Тургенев был в смятении, не зная, что предпринять. «Вызывать меня теперь (в Сенат), после “Отцов и детей”, после бранчивых статей молодого поколения, именно теперь, когда я окончательно - чуть не публично - разошелся с лондонскими изгнанниками, т. е. с их образом мыслей - это совершенно непонятный факт», - писал он П. В. Анненкову [Тургенев 18: 82-83]. Тургенев отправил личное письмо Александру II с просьбой выслать «допросные пункты» за границу. Он вызвал к себе брата Николая, чтобы договориться с ним о своих имущественных делах на случай возможной конфискации имения.

Одновременно Тургенев обратился с просьбой о помощи к А. К. Толстому и Б. М. Маркевичу, которые были тесно связаны с императорским двором. Толстой с детских лет был другом императора, а Маркевич входил в ближайшее окружение императрицы Марии Александровны. В начале 1863 г. Толстой вместе с семейством Маркевича находился в Германии. 3 апреля состоялось его венчание с Софьей Андреевной Миллер в православной церкви Дрездена.

Завязалась переписка. 9 (18) февраля 1863 г. Тургенев сообщал Маркевичу: 
Я не мог вам ответить тотчас же, мой дорогой друг, так как только вчера вернулся в Париж - из маленького путешествия в Брюссель. Позвольте мне сказать вам, прежде всего, насколько ваше письмо, такое теплое и дружеское, меня тронуло. Обычно нам протягивают руку отнюдь не тогда, когда на нас обрушивается несчастье; а вы сделали это с таким великодушием и искренностью, что я могу только сказать вам: благодарю - от глубины сердца.

Я употребил слово: несчастье; надо бы сказать: кирпич, так как то, что случилось со мною, так же глупо и неожиданно, как кирпич, свалившийся на голову. Обвинять меня в сговоре с Герценом в связи с изданием моего последнего романа и посреди оскорблений, которыми осыпает меня партия красных, - это нечто столь чудовищное, что самая эта чудовищность сообщает ему некое правдоподобие. «Должно быть, под этим что-нибудь скрывается, - скажут любопытные, - иначе бы не решились на такую меру». Думаю, не стоит вам и говорить, что под этим нет ничего, совершенно ничего. Я отсюда слышу неудержимый смех Герцена, которого я не видел с мая и с которым мы в начале этой зимы обменялись пятью или шестью письмами, приведшими к окончательному разрыву, потому что наши убеждения никогда не сходились. Я старый либерал, но я также и старый монархист, между тем как он - вы знаете, что он такое.

Вы меня спрашиваете, какое впечатление на меня все это производит: я этим огорчен, но, смею утверждать без ложной гордости, больше за правительство, чем за себя. Если бы дело шло о том, чтобы предстать перед настоящим судом, я бы немедленно явился; но я мало доверяю правосудию нашего Сената - и притом, кто может поручиться, что даже умеренные мнения не будут наказаны? Подвергнуться предварительному заключению, чтобы затем два или три года прозябать в глухой провинции? Я слишком стар для этого. По совету нашего посла, г-на Будберга, я написал письмо государю: я умоляю его приказать выслать мне «допросные пункты» так, кажется, принято их называть - и клянусь честью ответить с совершеннейшей искренностью на каждый вопрос; теперь я ожидаю. Должен прибавить, что г-н Будберг держал себя в этом случае превосходно: он сам написал Долгорукову и т. д.

Скажите Толстому, что я получил его письмо и отвечу ему завтра же: он может поступить с моим письмом так, как сочтет нужным. Вы забыли надписать ваш адрес - пишу на адрес Толстого (кстати, я так и не получил другого вашего письма, о котором вы говорите). Передайте мой почтитель- 
ный привет г-же Маркевич и примите, вместе с пожеланиями скорейшего выздоровления вашему ребенку, уверение в признательности и неизменной дружбе. И. Тургенев [Тургенев 18: 417-418].

Сохранилось ответное письмо Маркевича Тургеневу из Дрездена 21 февраля 1863 г., которое в советский период было принято не цитировать, так как в нем содержалось подробное описание чтения Маркевичем «Отцов и детей» императрице Марии Александровне и государю Александру II. Факты интересные. Поэтому мы приведем это письмо целиком:

Я, право, не знаю - имею ли я право принять благодарность от Вас, милый и добрый друг мой Тургенев. В чувстве моем к Вам гораздо более эгоизма, нежели сколько это кажется с первого раза. Если бы Вы были просто отличный человек, это чувство, вероятно, было бы бескорыстнее, но Вы мне, кроме того, еще дороги всем тем, чем был, например, Пушкин дорог друзьям своим, и поэтому в этом случае я и сам не знаю, что более тянет меня к Вам, - сердце ли мое или моя эпикурейская натура, благодарная за столько доставленных ей наслаждений. Не прогневайтесь, человек даровитый в этом случае, как богач, не имеет права рассчитывать на совершенно бескорыстные к нему привязанности.

Но шутки в сторону, я до сих пор не могу прийти в себя после того оглушительного удара, после письма отца Жемчужникова, которое принесло нам первое известие о предании Вас суду «за намерения произвести переворот в государстве».

Боже мой! Что за нелепости они делают там. Вот уже можно сказать, что нет хуже врагов, как сами они себе. Вчера утром Толстой принес мне прочесть Ваше письмо к нему; но за час перед этим я отправил пространное письмо к M-me Rahden ${ }^{1}$, включив туда же и Ваше письмо ко мне. Логичный вывод из факта Вашего обвинения так ясен, что в письме моем к ней я говорю почти буквально то, что говорится в Вашем письме к Толстому. Между прочим, следующее: «Предположив, что Тургенев явиться в Пе-

\footnotetext{
${ }^{1}$ К. П. Победоносцев, хорошо знавший великую княгиню Елену Павловну и ее гофмейстерину Эдиту Феодоровну Раден, отмечал, что благодаря этим женщинам Михайловский дворец сделался средоточием культурного общества в Петербурге, центром интеллектуального его развития.

2 Закавыченный далее французский текст обращения Маркевича к M-me Rahden мы даем в переводе на русский язык.
} 
тербург, очевидно, не пожелает, надо думать, если не брать середины, что он будет приговорен к ссылке. При такой постановке отдает ли себе отчет правительство в дилемме, которая развертывается перед ним в этом случае: или Тургенев человек мстительный и перейдет в ряды ожесточенных врагов правительства и тогда он будет гораздо опаснее самого Герцена, или же (что представляется весьма возможным для тех, кто знает Тургенева) он не отступит ни на пядь от своих принципов умеренности и от своих убеждений либеральных, но все же монархических, как он мне сказал, и в таком случае позиция правительства не окажется ли нелепой лицом к лицу с произведениями, на которых запечатлелся этот дух ума и сдержанности далекого изгнанника, осужденного как анархист и революционер?»

Я умоляю M-me Rahden показать Ваше письмо, да и мое тоже, великой княгине Елене Павловне. Она умнее всех их там и лучше всех может понять, в какой мере правительство sich furchtbar blamirt hat ${ }^{1}$, как говорят немцы. Тупоумие, юридическое невежество, неведение того, что у нас делается под носом, никогда так сильно, так колоссально глупо не изобличали себя, как в этом деле. Ненавидя нигилизм и красную пропаганду, мне в особенности больно за тот триумф, которым увенчиваются они при сей верной оказии. Сколько людей (я это тоже пишу M-me Rahden), которых «Отцы и дети» заставили оглянуться в недоумении и усомниться в правде крайних убеждений, вернутся к ним опять и возненавидят с возобновленной силой. Все это, особенно за границей, далеко от места действия, где все-таки, думалось, можно было бы самому что-нибудь сделать, растолкать равнодушных, направить неумелых, зайти в кулисы всей этой гнусной шутки - все это страшно меня волнует и мучит. Все это представляется мне одной из тех пагубных свалок, когда ночью в паническом страхе воины одного лагеря режут друг друга, не распознавши себя в темноте. Я, признаюсь Вам откровенно, очень жалею императрицу, к которой питаю весьма благодарное чувство, как за себя лично, так и за те честные благородные убеждения в ней, которые я имел случай заметить именно при чтении моем ей и государю «Отцов и детей» в прошлом году, Вы не получили моего письма, в котором я подробно говорил об этом, и я объясняю себе это тем, что письмо это я отправил Вам с означением, сколько помнится, нумера дома Вашего неверно, и притом перед отъездом моим в деревню в мае, т. е. почти в то же время, когда Вы были в России, как я узнал потом.

${ }^{1}$ Страшно себя скомпрометировало (нем.). 
Дело в том, что императрица (у которой нет той force d imitation ${ }^{1}$, которою отличается Елена Павловна, но зато гораздо более артистического и сердечного понимания) - императрица наслаждалась «Отцами и детьми», как наслаждался я сам (et c'est beaucoup dire 'a mon avis², без самохвальства). Чтение продолжалось целых восемь часов, она два раза отказывалась от концертов, в которых присутствие ее было объявлено, чтоб между чтением не было слишком длинных промежутков. Никакая тонкость, никакой намек, что меня даже удивило, не прошли не замеченными ею. О привычках внезапной глухоты ради важности русских сановников она заставляла меня повторять еще раз для себя, а другой еще раз для государя, причем оба хохотали от души. Мальцова ${ }^{3}$ тут присутствовавшая, хотела было, в видах внешнего благочестия, уязвить П. П. Кирсанова за отношение к Феничке, но императрица объявила, что в слабости его так много нежности, что она чувствует к нему полную симпатию. Все это я передаю Вам словами, которые не в силах передать того хорошего, честного настроения, в котором я видел эту женщину, ту, скажу ли, теплую благодарность, которая, для меня очевидно, просвечивала в ней к писателю, в убеждениях которого она могла до этих пор сомневаться, но который в эту минуту являлся ей красноречивым представителем ее собственных задушевных убеждений. В этом тоне, теплом и искреннем, просила она передать Вам ее благодарность. Мне в эту минуту, я помню, вспомнилось о Барнове 4 .

Из этого Вы можете заключить, какое именно впечатление она произвела на меня. Скажу Вам лучше. Государь, обыкновенно не только равнодушный, но чуть не враждебный всем этим «чтениям», играл со своими приближенными в той же комнате, где читали «Отцы и дети». Чем далее подвигалось чтение, тем ближе подвигался его карточный стол к круглому столу, за которым мы сидели за книгой, - и наконец, в самые последние вечера генералы его играли одни, а он сидел за нашим столом, слушал, смеялся и сочувствовал старикам Базаровым вместе с нами. Я с удовольствием

${ }^{1}$ Силы подражательности (франи.).

2 А это, на мой взгляд, много значит (франи.).

3 Мальцова Анастасия Николаевна - чтица великой княгини Елены Павловны.

${ }^{4}$ Барнов (Барнав) Пьер Антуан (1761-1793) - деятель Великой французской революции, член Национального собрания, выдающийся оратор. Якобинцы обвинили его, сторонника конституционной монархии, в роялизме и гильотинировали. 
вспоминаю об этих чтениях: я Вашими устами говорил им: «Вы видите, что Русская мысль вам не враждебна с той минуты, как вы перестали гнать и давить ее; вы видите, что эта мысль плодотворнее всех ваших административных распорядков, и что честный и независимый Русский писатель служит вам лучше всех ваших Генералов». Не знаю, понял ли он эти не выговоренные речи, но она, видимо, всем сердцем понимала их, и этого я никогда не забуду. Мне поэтому истинно больно думать, что эта отличная женщина может предполагать теперь, что Тургенев враг ее, враг государства, что она может опять заподозрить Русскую мысль, Русскую свободу.

Но я всё еще не верю в серьезность всей этой истории. Much ado about noting ${ }^{1}$, вот что, я уверен, выйдет из всего этого. Они должны одуматься, но, как пишу я M-me Rahden, идя по строгому логическому пути, вся мыслящая Россия, понимающая лучше тупых подлецов Правительства всю нелепость обвинений Тургенева, но, принимая эти основные выводы, не имеет ли полного права предполагать, что все остальные лица, обвиненные вместе с Тургеневым, точно так же виноваты, как и он, в «намерении произвести переворот в государстве»? Какое же может быть после этого доверие к Правительству? Вот уж можно при этом вспомнить известное изречение: спаси меня, Господи, от друзей моих!

До свидания, добрый друг мой. Вооружайтесь терпением в виду этой «последней тучи рассеянной бури». Она должна пройти, не задевая Вас, или Герцен будет прав, обвиняя Россию в несостоятельности.

Обнимаю Вас крепко, как люблю. Б. Маркевич» [И. С. Тургенев. Из неизданной переписки: 290-293].

Вскоре в Париж пришли «допросные пункты», Тургенев ответил на них и несколько успокоился. Однако Сенат не удовлетворился ответами, и вызов в Россию был повторен. Поскольку Тургенев довольно долго откладывал поездку под предлогом болезни, в Петербурге распространился слух, что писатель испугался судебной ответственности и решил остаться в эмиграции. Сочувствующие пострадавшим по этому делу люди упрекали Тургенева в том, что он своей неявкой отягощает положение других обвиняемых. Писатель оказался, таким образом, в весьма щекотливой ситуации как справа, со стороны правительственных верхов, так и слева, со стороны радикальной части русского общества. Пришлось ехать в Россию. Заступничество Б. М. Маркевича и

1 Много шуму из ничего (лат.). 
А. К. Толстого возымело силу. Судьи в Сенате удовольствовались тем, что вручили Тургеневу досье его дела и указали страницы, на которых упоминалось его имя, предложив дать письменные разъяснения.

Хотя в письмах и Тургенев, и Маркевич подчеркивали глубокие дружеские чувства, в действительности между ними существовали противоречия, которые привели в 1870-е гг. к полному разрыву. У Маркевича нигилизм вызывал резко отрицательную реакцию. В письме к Тургеневу он говорит, что «ненавидит нигилизм и красную пропаганду», тогда как автор «Отцов и детей» испытывал по отношению к Базарову очевидное сочувствие. Маркевич знает, как оценил М. Н. Катков рукопись этого романа: «Если и не в апофеозу возведен Базаров, - писал он Тургеневу, - то нельзя не сознаться, что он както случайно попал на очень высокий пьедестал. Он действительно подавляет всё окружающее. Всё перед ним или ветошь, или слабо и зелено. Такого ли впечатления нужно было желать? В повести чувствуется, что автор хотел характеризовать начало, мало ему сочувственное, но как будто колебался в выборе тона и бессознательно покорился ему. Чувствуется что-то несвободное в отношениях автора к герою повести, какая-то неловкость и принужденность. Автор перед ним как будто теряется, и не любит, а еще пуще боится его [Тургенев: 14: 104].

Да и сам Тургенев признавался в симпатии к Базарову. В письме к А. И. Герцену от 16 (28) апреля 1862 г. он писал: «Милый Александр Иванович. Немедленно отвечаю на твое письмо - не для того, чтобы защищаться, а чтобы благодарить тебя - и в то же время заявить, что при сочинении Базарова я не только не сердился на него, но чувствовал к нему “влечение, род недуга”, - так что Катков на первых порах ужаснулся и увидел в нем апофеозу “Современника” и вследствие этого уговорил меня выбросить немало смягчающих черт, в чем я раскаиваюсь. Еще бы он не подавил собою “человека с душистыми усами” и других! Это торжество демократизма над аристократией. Положа руку на сердце, я не чувствую себя виновным перед Базаровым и не мог придать ему ненужной сладости. Если его не полюбят, как он есть, со всем его безобразием - значит я виноват и не сумел сладить с избранным мною типом» [Тургенев 4: 382-383]. 
Неприятие нигилизма Катковым и Маркевичем было связано в первую очередь с их патриотическими убеждениями, оценка которых нуждается ныне в существенных коррективах. События реформы 1861 г. привели страну к глубокому кризису, зашатались коренные основы государственного строя. «С одной стороны, говорили, что надо дать свободу всем угнетенным, в том числе и национальностям, ее добивающимся; с другой стороны, бродили мысли о необходимости расчленения России как слишком большого политического целого наподобие федеративного государства. Герцен благовестил эти мысли в своем “Колоколе" и они разносились с эффектом по Европе. Помимо польских патриотов появились, между прочим, еще украйнофилы; в литературе промелькнуло учение о двух русских народностях и двух русских языках» [Неведенский: 164].

Возникла реальная угроза распада страны. Достоевский писал в романе «Бесы», что на либеральных сходках уже всерьез заговорили тогда «об уничтожении цензуры и буквы ъ, о замене русских букв латинскими, $<\ldots>$ о полезности раздробления России по народностям с вольною федеративною связью, об уничтожении армии и флота, о восстановлении Польши по Днепр...» [Достоевский 10: 22].

Первым симптомом начавшегося кризиса русской государственности стало Польское восстание 1863 г., целью которого было воскрешение Великой Польши от Данцига до Одессы. Катков в статье «Отзывы и заметки. Польский вопрос», замечал, что поляку «недостаточно быть поляком; он хочет, чтоб и русский стал поляком или убрался за Уральский хребет. <...> Что не Польша, то татарство, то должно быть сослано в Сибирь, и на месте нынешней могущественной России должна стать могущественная Польша по Киев, по Смоленск, от Белого до Чёрного моря» [Катков 1863: 477].

О солидарности с восставшими поляками заявили открыто Герцен и Бакунин в Лондоне и значительная часть «нигилистов» в России. «19 февраля, в самый день восшествия на престол ныне царствующего императора и вместе в годовщину освобождения народа от крепостной зависимости», разбрасывалась в Москве прокламация со штемпелем Земля и Воля». Её авторы «от лица русского народа, взывали к нашим офицерам и солдатам в Польше» обратить оружие «против своего отечества» [Катков 1863: 479]. 
Восставших поляков поддержали почти все ведущие страны Запада. «Польская интрига царила в Европе. Пока русские войска сражались с мятежниками в равнинах Вислы и Немана, в Европе происходили многочисленные манифестации с выражением сочувствия полякам. Устраивались митинги, произносились пламенные речи, собирались подписи в пользу повстанцев. Пущены были в ход громкие фразы об угнетении слабого сильным и необходимости даровать политическую свободу и независимость порабощенным, - фразы, которыми наши западноевропейские друзья маскировали свою затаенную ненависть к России и сочувствие ее врагам» [Неведенский: 171].

Маркевич заявлял в письме к А. К. Толстому: «Не надо забывать, что Европа нас ненавидит, но в то же время и боится нас, боится более всего того, чтоб мы не росли и не развивались, так как если мы будем сильны и цивилизованы, то слово наше будет законом для Европы. Поэтому мы должны остерегаться ее похвал - ей будут улыбаться только наши промахи - и не обращать внимания на ее порицания и проклятия, которые будут служить лишь доказательством того, что мы избрали верный путь, долженствующий привести нас к славному и счастливому будущему» [Письма: 98].

Признать за поляками и прибалтийскими немцами право политической автономии - это значило бы, по словам Маркевича, «признавать за этими национальностями право полонизировать и германизировать русских, латышей и финнов; это значило бы допускать зародыш будущих независимых государств, крайне враждебных России, которые, опираясь на туземные населения, онемеченные и ополяченные благодаря нашему рыцарскому великодушию, стали бы живой стеной между нами и Европой и отодвинули бы нас к Азии к вящему удовольствию французских и прочих газет, проповедующих крестовый поход против нашего варварства» [Письма: 112].

Друг Маркевича А. К. Толстой в этом вопросе занимал аналогичную, хотя и более сдержанную позицию. «Он прекрасно понимал, что “союз равных" возможен только как внегосударственное образование и чреват утратой единства внутри империи, ее кризисом и распадом. Солидаризируясь с теми, кто стремился к русификаторству как конечной идеальной цели, он расходился с ними в отношении к методам достижения этой цели, подчеркивая, что нетерпеливость и силовая жесткость могут лишь повредить, ибо вызовут естественное противодействие» [Федоров: 136]. 
Патриотизм Каткова и его сторонников, писателей «московской плеяды», был «в высшей степени полезным для России в тяжелые минуты польского мятежа; под влиянием его слова пробудился в народе и в интеллигентной среде взрыв патриотического негодования против врагов России, столь необходимый для поддержки правительства в виду надвигавшейся опасности» [Неведенский: V].

Как русский патриот, Маркевич подвергал суровой критике позицию «цивилизованного» Запада не только к России, но и к православно-христианским народам Греции, Сербии и Болгарии. Обращаясь к А. К. Толстому, разделявшему западнические убеждения, Маркевич писал: «Вы, несмотря на то, что подсказывает вам ваше сердце, ищите для них извинения во имя той же западной цивилизации - не так ли? Я же, дорогой друг, с гордостью принимаю это прозвище татарина, с презрением брошенное нам просвещенным западом, и проклинаю того из моих предков, который, ослепленный фальшивым блеском этой цивилизации, отрекся от своего восточного варварства, чтобы стать поляком или католиком, т. е. сознательным палачом христиан, на жалованье у турок. Я счастлив сознанием, что я русский в душе, то есть принадлежу сердцем к единственной нации, с негодованием протестующей против отвратительного образа действий просвещенной Европы относительно греков и славян на востоке» [8, с. 138].

Автор исследования «Русский роман и русское общество» К. Головин убедительно говорил о позитивной основе программы Каткова и его соратников: «Прямого сочувствия к крепостному праву и канцелярскому суду, конечно, ими не высказывалось, но в ослаблении власти, в расшатывании общественной иерархии, в чересчур широком применении выборного начала усматривался источник умственной и политической смуты, охватившей Россию. Дерзкая критика нашего государственного строя, громко провозглашаемая благодаря уступчивости и попустительству свыше, отрицание начал, на которых выросло русское государство, то есть православной веры, самодержавия и народности, и, в связи с этим, коварная польская смута, - вот непременная, почти казенная тема большинства романов и повестей этой школы» [Головин: 368].

В романе Маркевича «Марина из Алого Рога» (1873) княгиня Солнцева говорит, «что настоящие на Руси нигилисты - это мы, сливки, наше общество, наш Петербургский монд...» [Маркевич 1873: 202]. 
Ей вторит князь Пужбольский: «Наши Базаровы давно перестали лягушекрезатьинаполовинусидяттеперьвзвездахитолстыхэполетах...<..> И вы себе представьте теперь, как легко независимому мнению выступать с ними в бой, на публичную арену!.. С одной стороны - Базаров в звездах, который, если посмеешь сомневаться в его благонадежности, потребует, чтобы тебе административным порядком глотку зажимали; с другой - вся орда Базаровых без звезд, которая во все водосточные трубы свои начинает поливать гражданские слезы и во все свои вороньи горла каркать, что ты мерзотнейший обскурант, враг реформ...» [Маркевич 1873: 227-228].

Маркевич солидарен с Достоевским, который в романе «Бесы» (1871-1872) показал союз губернатора Лембке и его супруги Юлии Михайловны с нигилистом Петром Верховенским. Этот союз изображался в романе как явление естественное и распространенное. Консервативная дворянская верхушка и бюрократическая администрация смотрели на Россию с позиций, близких к нигилистическим. Крайние «западники», они разделяли германо-романские воззрения, согласно которым православные славяне относятся к числу «пассивных», «женственных» наций, обязанных немцам культурой и цивилизацией.

Именно критическое отношение к современному чиновничеству и правительственной бюрократии сближало Маркевича с Тургеневым и Достоевским. Но либеральное западничество Тургенева, наиболее радикально проявившееся в романе «Дым», а также его сдержанное сочувствие к «нигилистам» шестидесятникам и к «народникам» семидесятникам вызывало у Маркевича и писателей его круга резкое неприятие.

Маркевич критически относился и к славянофилам, которые искали опору русской государственности в православном народе и крестьянской общине. Вслед за Катковым Маркевич видел эту опору не в широких слоях русского православного крестьянства, а в союзе патриотически настроенных дворян. «Его заветной мечтой было положить в основании обновлявшегося строя русской жизни твердый и способный к самоуправлению класс землевладельцев наподобие английского джентри» [Неведенский: 116]. Именно такого положительного героя, бросающего вызов тургеневским «лишним людям» и радикальным «нигилистам», утверждал Маркевич в своих произведениях. 
25 февраля 1867 г. Тургенев привез в Петербург рукопись романа «Дым». 26 и 27 февраля на его чтении были П. В. Анненков, В. П. Боткин, В. А. Соллогуб и Б. М. Маркевич. Чтение прошло с большим успехом. Обращаясь к Каткову, Маркевич так информировал главного редактора журнала: «Два дня не отрываясь прошли в слушании и чтении этой превосходной вещи, по мастерству и магистральности приемов лучшей изо всего, что было до сих пор написано Тургеневым <...> Отношения автора к своему предмету, к участвующим в драме лицам отличаются свободою и откровенностью, в которых чуялся сильный недостаток во многих вещах Тургенева» [Тургенев 9: 520].

Вероятно, под «магистральностью приемов» Маркевич имел в виду иронически сниженное освещение русских нигилистов в кружке Губарёва, действительно отличающееся не свойственной Тургеневу сатирической прямотой. Принял Маркевич и обличительные страницы, посвященные описанию пикника генералов в Баден-Бадене. Вторя Тургеневу, он писал А. К. Толстому 21 декабря 1868 г.: «Хотя я по природе вовсе не склонен к пессимизму, но, судя по тому, как идут у нас дела, я сильно боюсь, чтобы “молодые генералы”, ныне нами правящие, не привели нас, всё под тем же предлогом противодействия нигилизму, обратно, к счастливым временам, когда кулинарное выражение “поставить на вольный дух" возбуждало подозрение в якобинстве» [Письма: 86].

Как принял рукопись «Дыма» Катков? «Новая беда, - писал Тургенев Полине Виардо после свидания с издателем «Русского вестника», - г. Катков создает такие большие затруднения моему злосчастному роману, что я начинаю сомневаться, можно ли будет опубликовать роман в его журнале. Г-н Катков во что бы то ни стало хочет сделать из Ирины добродетельную матрону, а из всех генералов и фигурирующих в моем романе прочих господ - примерных граждан; как видите, мы далеки от того, чтобы столковаться. Я сделал некоторые уступки, но сегодня кончил тем, что сказал: “Стоп!” Посмотрим, уступит ли он» [Письма: 410].

Катков уступил. Пришлось лишь сделать купюры в описании пикника генералов. Но «добродетельную матрону», Надежду Павловну Чемисарову, и «примерных граждан» в лице столбового дворянина Павла Васильевича Чемисарова и героя Крымской войны, моряка Владимира 
Кемского читатель встретил на страницах «Русского вестника» сразу же вслед за «Дымом». Они воскресли и заявили о себе в романе Маркевича «Типы прошлого».

Первая часть этого романа напоминает столь любимые Тургеневым предыстории. Действие ее отнесено к 1849 г., ко времени разгрома кружка Петрашевцев и наступления правительственной реакции. «"Разбейтесь силы, вы не нужны!" говорилось в одном, разумеется, не печатном, стихотворении той эпохи» [Маркевич 1867. 8: 522]. Речь тут шла о стихах И. С. Аксакова:

Пусть гибнет всё, к чему сурово

Так долго дух готовлен был:

Трудилась мысль, дерзало слово,

В запасе много было сил...

Слабейте силы! вы не нужны!

Засни ты, дух! давно пора!

Рассейтесь все, кто были дружны

Во имя правды и добра! [Аксаков: 94].

В это смутное время на «ярмарку невест» съезжается в Москву русское провинциальное дворянство, прибывают столичные искатели, пленяют «красавиц своею ловкостью, звездами или вензелями и увозят их на берега Невы» [Маркевич 1867. 8: 523]. Привозит свою дочь в Москву и Павел Васильевич Чемисаров, потомственный дворянин. В эпоху смуты и междуцарствия его прадед собрал на свой счет рать и вместе с князем Пожарским освобождал Москву от поляков. Характер его полемичен по отношению к тургеневским Осининым, которые были тоже глубоко укоренены в русской истории, но «забеднял, “захудал” их род - не поднялся ни при Петре, ни при Екатерине и, всё мельчая и понижаясь, считал уже частных управляющих, начальников винных контор и квартальных надзирателей в числе своих членов» [Тургенев 9: 179].

Герой Маркевича, напротив, сохранил свое богатое поместье и свое дворянское достоинство. Воспитанник Чемисарова Кемский так характеризует его: «Скажу тебе одно на первый случай: человек он далеко не заурядный, и всё реже и реже попадаются такие в наше время. “Чемисаровы литые родятся", - сказал он мне однажды. И точно, он 
какой-то литой с головы до ног. $<\ldots>$ Он в продолжение всей своей жизни ни разу не усомнился в том, что ему следовало делать, не уступил ничьему чужому мнению и не изменил однажды принятому им намерению, чего бы это ему ни стоило» [Маркевич 1867. 8: 535].

Каковы же идеалы этого дворянина? Они раскрываются в его споре с соседом, помещиком Грайворонским. Об этом споре рассказывает дочь Чемисарова в своем дневнике:

Сила, — перебил его снова батюшка. - У вас вот, например, пять тысяч душ, земли пол уезда, дом в имении - дворец, - а вы катите с вашею силой на поклон к генералу Карягину! Впрок пошла она вам! хвалю! <..> Поглядите-ка на остзейского барона, как он крепко сидит на своем риттерсгуте ${ }^{1 !}$ Попробуйте ссадить его оттуда! Нет, он-то силу свою знает. Зато, спросите, кто к кому у них там забегает: они ли к Карягиным, или Карягины к ним? А у нас? Где она, сила-то ваша? В Петербурге - воду толчет, в передних случайных людей чинов себе вымаливает, в Москве - в карты, на безумные пиры разоряется. Про силу толкуете, - желчно повторил батюшка, - a того до сих пор не поняли, что она у вас под ногами, в той земле, на которой сидите вы... Сверху, наконец, указана вам ваша задача; или, полагаете, призывая к жизни поместное дворянство, великая государыня не знала, что делает? Да нет, где нам! - воскликнул он с глубокою горечью: - не по силам задача! Труд на то нужен, терпение, воля, скуку переносить, с серым мужиком возиться! Воспитать себя к тому нужно, человеком надо быть! Скажите прямо, много ли из нас вглубь себя прияло, что служить царю и земле плугом и бороной, хотя бы собственными руками, в тысячу крат честней и полезней, чем тешить свое презренное тщеславие, жертвуя ему всем: прямым долгом своим, честью, родовыми поместьями с отцовскими могилами, благом подвластных людей и, в конце концов, будущим своей страны... Потому недалеко уедешь там, где, куда ни обернись, всюду чин, а гражданина - нигде!.» [Маркевич 1867. 11: 150-151].

Воспитанник Чемисарова Владимир Кемский, влюбленный в его дочь Надежду, - антипод Литвинова. Выпускник Царскосельского лицея, моряк, Кемский два года назад вернулся из кругосветного путешествия, провел шесть месяцев в родном для него гнезде, признался Наденьке в любви, но помолвка не состоялась. Неожиданно Кемский

1 Риттерсгут - рыцарское поместье. 
получил приказ явиться на службу, и вынужден был отправиться в очередное плавание.

Долг, любовь к отечеству, православная вера для него превыше всего. Вернувшись в Москву, он со своим лицейским другом едет к Кремлевским соборам.

Стой! - закричал Кемский, выскочил из саней, снял кивер и стал набожно креститься. - Год тому назад, в Охотском море, нас прибило штормом к берегу, <..> мы погибали. Три дня и три ночи, под страшным прибоем, стаскивались мы с мели. Ветер не утихал, мы потеряли всякую надежду. Матросы надели белые рубахи. Я утомился страшно, опустился у грот-мачты и заснул как убитый. И в это время мне приснился вот этот сон, - промолвил он, обводя кругом рукой, - Кремль с его святыней, и эта бесконечная даль, и в каждом доме этот огонек лампады перед семейными, старинными иконами... Я помню, я проснулся тогда весь в слезах; чудные, брат, сладкие были эти слезы! Мне не хотелось умирать, а в этом сне я почерпнул какую-то неодолимую надежду в наше спасение. И точно: на заре ветер переменился против всякого чаяния. И вот, как видишь, я живу и... и счастлив, - повторил он опять. - Оторваться не хочется отсюда, - продолжал Кемский, облокачиваясь на решетку, — какая тишь, какая ширь кругом! И, не правда ли, кажется, что какое-то таинственное, от века жданное слово должно сейчас сказаться тебе от этого безмолвия и шири необъятной? Вся наша Русь родная сказалась в этой картине... [Маркевич 1867. 9: 531].

Спустя много лет рассказчик встречается с постаревшим, израненным Кемским в Баден-Бадене. Описание этого курортного города полемический вызов Маркевича автору «Дыма». Рассказчика встречает здесь известный московский «западник» с говорящей фамилией Секкаторов. Этот дворянин отличается «своим тончайшим обращением» и «голосом, имевшим особенное свойство напоминать вам о том, что есть на свете сладкие вещества, в роде патоки и сдобного теста...» [Маркевич 1867. 9: 43]. Произношение Секкаторова - пародия на знаменитые тургеневские «пришепётывания». В письме от 27 февраля 1869 г. к А. К. Толстому Маркевич так имитирует их. Автор «Дыма» в его интерпретации говорит, что стих «Воеводы» Островского «тецёт как какой-то мягкий руцей и что зутко и сладко щекоцет его этот стих, 
словно льётся ему в грудь эта бесконецная и сирокая русская волна...» [Письма: 102].

«Нельзя было ошибиться: эта мягкая речь, этот сдобный баритон могли принадлежать единственно просвещённому г. Секкаторову» [Маркевич 1867. 10: 480]. На вопрос, был ли он в деревне в момент эпохального события 19 февраля, Секкаторов отвечает: «Не был. Признаюсь, рвался в Европу. Вы согласитесь, что лучшего момента нельзя было выбрать, потому, согласитесь, до сих пор что мы были? Варвары, Скифы-рабы, на которых еще Геродот с презрением указывал пальцем. Ведь Скифы мы были, вы согласны? <...> А теперь мы можем с вами смело протянуть руку каждому иностранцу и сказать ему: “Любезный мой, не сердись, мы также сыны свободного народа; полно давить нас под исполинскою пятой твоей гражданственности!”» [Маркевич 1867. 10: 481].

Известно, что Тургенев не был в России в момент подписания Манифеста, за что получил упрек и порицания от многих друзей, даже от Герцена. Секкаторов - иронический отклик на тургеневского Потугина и на самого автора романа «Дым».

Но внимание Маркевича на этих пародийных страницах не задерживается. В центре повествования оказывается другое - диалог Кемского с повествователем. Обращаясь к нему, Кемский говорит:

«Помнишь, в наше последнее свидание в Москве ты мне как-то выразился - слова твои тогда врезались мне в память, - что мне завидовать можно, что для меня нашлось настоящее дело в жизни. Было оно действительно у меня, это дело, и нет его, сгинуло оно на веки веков. Были люди близкие, и никого нет, все там полегли... Остался я <...> одинок, никому не нужен... Пойми, каково это сказать себе: ты, милый мой, хоть выжми, ни на какую потребу негоден, ты лишний человек на этом свете!.. Ведь я в голову ядром контужен», — объяснил он, как бы извиняясь предо мной... <... «Ты своё сделал, тебе не в чём себя упрекать, - перебил я его. - Лишний человек, говоришь ты про себя. Послушали бы тебя те молодцы, - богато было ими наше поколение, надо признаться, - которые в этом гордость свою полагали, женские сердца покоряли именно тем, что лишние они... А ты где свою правую руку оставил?» - «Там, где бы с радостью и голову сложил! - живо воскликнул Кемский, и вдруг остановился, как бы устыдившись своего порыва. - Ты и не поймёшь, может быть, что значило для 
нас, Черноморцев, отдавать его! - продолжал он уже спокойнее; - ты не суди о нас по тому, что тебе пришлось, может быть, почитать об иных защитниках Севастополя, о разных гвардейских моншерах и штабных молодчиках ${ }^{1}$. Мы знали, за что стояли и что отстаивали; не из-за чинов же ведь, в самом деле, и аксельбантов полегло там всё, что у нас было лучшего!..»

Страстный моряк заговорил в Кемском. Он вспомнил о «незабвенном Михаиле Петровиче», о ненавистных Англичанах, «исконных врагах русской морской силы», о корвете, которым он, Кемский, командовал в день Синопского боя, о добродушном герое Нахимове, о слишком мало ведомых подвигах всей этой доблестной семьи людей, <..> для которых так дорога была честь России и о которых «новая Россия», как выражался Кемский, быть может, слишком скоро позабыла [Маркевич 1867. 10: 486-487].

Эти страницы полемичны по отношению к герою тургеневского романа Литвинову, который после разрыва с Ириной потолокся несколько времени без дела, без связей, почти без знакомых; потом дворяне его уезда, считавшие, что своя рубашка к телу ближе, «упекли» его в ополчение, там он «чуть не умер от тифа в Крыму, где, не видав ни одного “союзника”, простоял шесть месяцев в землянке на берегу Гнилого моря; потом послужил по выборам, конечно не без неприятностей, пристрастился к хозяйству» [Тургенев 9: 149].

В романе Маркевича «Перелом» таким тургеневским героям дается невысокая оценка: «Я сын своего века, а люди этого века все, как известно, бесхарактерны... Возьмите хоть все мужские типы у Тургенева <...> Все они в своем роде Гамлеты... или вернее даже Гамлетики...» [Маркевич 1884: 238]. Литвинов, конечно, оказывается в их числе.

Встреча Кемского со своей невестой Надеждой в Москве перекликается с аналогичной встречей Литвинова с Ириной. Маркевич сознательно проводит тут полемические перепевы. Красота их избранниц таит в себе какую-то загадку. Об Ирине Осининой сказано: «Поразительны, истинно поразительны были ее глаза, исчерна-серые, с зеленоватыми отливами, с поволокой <..> Странное выражение было у этих глаз: они как будто глядели, внимательно и задумчиво глядели

1 Полемический намек на рассказ Л. Н. Толстого «Севастополь в мае», посвященный обличению тщеславия военной верхушки и штабных офицеров. 
из какой-то неведомой глубины и дали» [Тургенев 9: 180]. «Литвинов рассыпался в восторженных похвалах. Но Ирина $<\ldots>$ глядела куда-то вдаль своими странными, словно потемневшими и расширенными глазами...» [Тургенев 9: 189]. Загадка этих глаз, устремленных вдаль, заключается в страстном желании героини вырваться из скудного московского быта около Собачьей площадки в столичную жизнь, приобщиться к миру великосветского общества.

Надежда Чемисарова, напротив, в дворянском кругу занимает высокое положение. Один из завсегдатаев бала говорит: «Эта, милый мой, не с родни моим степнушкам. Это, братец мой, Европа! Ты ее сейчас в Петербург, в Зимний дворец вези, так она и там сама себя отрекомендует» [Маркевич 1867. 8: 524]. И загадочные глаза героини Маркевича, в отличие от Ирины Осининой, устремлены далеко не в столичную даль, а в глубину ее смятенной души. Ее «безучастные и безнадежные глаза» скрывают какую-то горькую тайну. По словам рассказчика, «на душе у этой Изиды что-то неладно» [Маркевич 1867. 8: 525].

«Внезапное появление Кемского, казалось, оживило этот мрамор. Губы ее побагровели, легкий румянец проступил сквозь тонкую кожу лица. Даже глаза ее, эти немые глаза, казалось, хотели заговорить; но мне вообразилось почему-то, что если бы точно заговорили они, не радостью, а каким-то сокровенным смущением отвечал бы ее взгляд на живой, говорящий взгляд Кемского. Но загоравшаяся искра погасла, едва сверкнув; глаза ее остались так же равнодушны и безучастны» [Маркевич 1867. 8: 528].

Вспомним, что Катков советовал Тургеневу сделать из Ирины «добродетельную матрону». Тургенев отказался. И вот в романе Маркевича осуществилась прямая художественная реализация этого катковского совета. Какую же тайну берегут от любимого человека глаза героини Маркевича? Почему она отвечает своему жениху решительным отказом?

Дворянин Чемисаров, реализуя свой идеал, создает в имении с символическим названием Рай-Воздвиженское семью, объединяющую самые различные слои русского общества. Эта «малая семья» прообраз будущей России. В нее входят не только властвующие дворяне, не только подвластные им крестьяне, но и демократические слои русского общества. К ним принадлежит, например, Кирилин, воспитанник Чемисарова - сын офицера, из однодворцев, старого 
сослуживца Павла Васильевича. «Мальчик с ранних пор показывал необыкновенные способности к музыке. <...> Павел Васильевич, согласно его желанию, отправил его учиться музыке в Москву. Там он как-то поссорился с учителем, у которого жил, захотел поступить в университет, переехал в Петербург; потом бросил и принялся опять за музыку. В Рай-Воздвиженское он вернулся два года тому назад...» [Маркевич 1867. 9: 32].

Вернулся Кирилин сюда не по своей воле. Он говорит Наденьке: «"Многие из друзей моих попали теперь в изгнание. И я сам, не знаю как здесь, а не за крепкими затворами, или не перестреливаюсь с Черкесами на Кавказе. Я должен был покинуть университет, погубил, может быть, всё мое будущее, если допустить, что оно могло быть у меня", примолвил он с каким-то заносчивым смирением...» [Маркевич 1867. 10: 524]. Смирение его заносчиво, потому что спас воспитанника от кары его опекун, его второй отец Павел Васильевич Чемисаров.

И вот новоявленный нигилист обращается к Надежде Павловне со своей обличительной проповедью. «"Вам трудно понять меня, я знаю, - начал он опять. - Для вас радужным венцом сложилось всё, что дает цену и прелесть жизни! Весь этот безобразный порядок, тяготеющий над нами, он создан лишь для того, чтобы вам было хорошо жить... и, слава Богу, если бы только вам!..” - “О чем говорите вы, я вас не понимаю?” - спрашивала я с удивлением. - “Как о чем? - воскликнул он, и серые глаза его сделались вдруг черными. - Я говорю обо всем этом изгнившем здании давно отжитого феодального строя, который поддерживается разными искусственными подпорками, о бессмысленных предрассудках, о нелепых авторитетах, в силу которых исковерканы все естественные условия жизни, и человеку жить нельзя, если он случаем рождения не попал в известную, привилегированную клеточку, вне которой нет спасения. Вот о чем я говорю, барышня!”» [Маркевич 1867. 10: 527].

Именно Кирилину-петрашевцу, предтече будущих «нигилистов» шестидесятых годов, суждено разрушить «воздвигнутую» Чемисаровым «райскую» идиллию и внести трагическую смуту в благочестивое русское семейство. Вернувшись в имение Чемисарова, он искушает Наденьку призраками европейской свободы. На соблазн он дает Наденьке роман Жорж Санд «Валентина». Юная девушка, воспитанная в православных традициях, вдруг чувствует при чтении этого романа 
жгучую, преступную и соблазнительную власть бесконтрольной, стихийной страсти над ее грешной душой.

«Да и когда же до этого бывали в моих руках подобные книги! Необузданным языком говорила в них любовь, любовь, о какой я не слыхала до этой минуты, какая-то грозная, свирепая любовь, не признающая ничего, кроме одной себя, навязывающаяся как тиран и как тиран попирающая все то, чему до тех пор я верила, пред чем я, без борьбы, без сомнений, преклонялась с детства. Жгучие, околдовывающие страницы, они пробуждали во мне неведомые до тех пор и беззаконные, - я это сознавала, я говорила это себе, - ощущения и помыслы... То леденела я под влиянием невольного и непонятного ужаса, то вся горела и замирала, и краска стыда покрывала мое лицо, и сердце билось, как должно биться оно, казалось мне, у преступника после совершенного им преступления... Но, бессильная уже противиться змеиному ее обаянию, я только лихорадочно жаждала дойти до конца книги, надеясь вырваться, наконец, из этого влекущего, но греховного, но мучительного мира...» [Маркевич 1867. 11: 168].

Заметим, что Кирилин искушает Наденьку созвучным Тургеневу взглядом на любовь как на безудержную страсть. Перед ее стихийной властью беззащитен как слабый, так и сильный человек. Своенравная, роковая, неуправляемая, любовь прихотливо распоряжается человеческой судьбой. Никому не дано предугадать, когда это чувство, как вихрь, налетит и подхватит человека на своих могучих крыльях и когда оно эти крылья сложит.

Кирилин, утверждая такой взгляд на любовь, не может понять поступка Кемского, который, повинуясь государственному долгу, вынужден был оставить на время свою невесту и отправиться в очередное плавание.

«Любит? - глаза Кирилина засверкали. - Любит и уехал отсюда?» И он злобно засмеялся. - «Он не мог, - сказала я, - его долг...» - «Не мог! Долг его! - повторил, прерывая меня, Кирилин. - Да позвольте вас спросить, что такое долг? Эластическая рамка, растяжимая до бесконечности или доводимая до ничтожества, по прихоти каждого, пышное слово без определенного содержания, смысл которого с сотворения мира и до наших времен изменялся миллионы раз и каждою единицей из числа миллионов, 
населяющих вселенную, толкуется разно! И из-за этого слова, из-за этого призрачного понятия человек, который вас любит, говорите вы, решается расстаться с вами, покидает то, что должно быть ему дороже всего на свете!.. Нет-с, так не любят!» [Маркевич 1867. 11: 178].

Наденька попадает во власть далеких от ее христианской души страстных помыслов и порывов. «Какими же сетями опутал меня этот человек? Чем успел он зацепить за все мои живые струны и затянуть их в своей безжалостной руке?.. Боже мой! Неужели это любовь? - с ужасом подумала я. - Эта грызущая боль, этот мятежный строй мыслей и чувств, эта непрерывная, невыносимая тоска, - так это все называется любовью!..» [Маркевич 1867. 12: 616].

И вот итог этого соблазна. Наденька идет ночью на роковое свидание с обольстившим ее Кирилиным:

«Пора мне!..» Я закуталась в бурнус, погасила свечи... и вдруг вся обмерла от невыразимого ужаса: из киота, озарённый светом одинокой лампады, прямо глядел на меня строгий лик Божией Матери, и темные уста ее как будто шевелились, будто говорили: «Куда ты от меня в этот поздний час? Куда? Остановись!..» Я закрыла глаза и с протянутыми вперед руками кинулась в сени; ощупью, придерживаясь к стене, всё еще не смея раскрыть замкнутые глаза, спустилась я с лестницы [Маркевич 1867. 12: 625].

«Добродетельная матрона» пала, но кто из читателей дерзнет бросить в нее камень, учитывая горький финал ее жизни? Конечно, тут содержится явная полемика с Тургеневым о природе любви, о ее неизбывной власти над слабым человеком. Маркевич устами Наденьки вершит приговор тому культу любви, которым пропитаны многие произведения Тургенева:

Я очнулась, и, с сознанием моей погибели, моего неслыханного позора, закипело разом в душе моей чувство невыразимой ненависти к виновнику его... - «О, бездушный, бессовестный человек! - не владея собой, дрожа от негодования, стыда и раскаяния, упрекала я его. - Каким адским обманом довели вы меня до этой пропасти! Я погибла, я пропала в этой жизни и в вечной, - понимаете ли вы, безбожный человек? Вы этой бездной отплатили мне за то, что я, как сестра родная, принимала участие 
в вашей жалкой судьбе, за мои слезы, за мое заступничество, за то, что я с отцом... Отец мой, мой честный отец! Боже мой! Что будет с ним!.. И кто же? Вы! Вы, кого воспитал он как сына, вы обесчестили его дочь!.. Не другом, не братом вернулись вы в этот дом, которому вы всем обязаны, а лютым, заклятым врагом! Вы подругу вашего детства приговорили к вечному сраму, к безвыходной, к бесконечной муке!» [Маркевич 1867. 12: 629-630].

Оправдывает ли Надежда Чемисарова свою миссию «добродетельной матроны»? Кемский так вспоминает о последнем свидании с ней:

Да, я ее видел. После шести лет разлуки, когда все, казалось, должно было быть кончено между нами, - она так просила меня об этом тогда, судьба опять свела нас... но где же, как? По целым дням не отходила она от моей постели, но для меня она была призрак... светлый призрак, - примолвил Кемский, подавляя вздох. - Я лежал в тифе, в госпитале, в том же Симферополе, где за несколько времени до этого умер ее отец. Странная болезнь, этот тиф! Я видел ее, я сознавал ее присутствие, но не сознавал ни моего положения, ни места, в котором я находился. Я жил какою-то своеобразною, необъяснимою, но полною и, поверишь ли, блаженною жизнью. Я понимал, что надо мной парит какой-то ангел в ее образе и хранит меня; глаза ее по часам не отрывались от меня, и я чувствовал, что я весь таю, таю как снег, под лучами этих грустно и ласково сиявших мне глаз. И никогда, может быть, не был я так счастлив, как в то время! Когда я выздоровел, одна старушка сердобольная, свидетельница ее забот обо мне, строго внушала мне всю жизнь мою молиться за «сестрицу». Оказалось, что я был окончательно приговорен и не умер только потому, что «она вымолила меня у Господа», как выражалась эта добрая старушка, заменившая ее у моей койки, когда слегла сама Наденька, и ее полумертвую, увезли из Крыма [Маркевич 1867. 10: 491-492].

Как откликнулся Тургенев на роман Маркевича? Какую оценку он ему дал? На этот счет до нас дошли очень приглушенные сведения. Многое потеряно. Сохранилось одно письмо Маркевича к Тургеневу, в котором он помогает своему «другу» опубликовать его повесть «Несчастная» в очередном номере «Русского вестника». В этом письме 
от 9 декабря 1868 г. Маркевич с какой-то вызывающей интонацией просит Тургенева прояснить его отзыв на роман «Типы прошлого»:

Искренне благодарю Вас за дружески откровенно выраженное Вами мнение о моем романе. Постараюсь последовать Вашим советам, если примусь опять за литературный труд. Хоть едва ли мыслимо выработать себе «оригинальную» физиономию, если по воле Провидения или, говоря более современно, по недостатку известной доли фосфора в мозгу, обречен походить на Петра или Павла, но я, по крайней мере, не буду так тщательно, как первый раз, стушевывать донельзя мою авторскую личность, - а старался я об этом потому, что боязнь навязывания этой личности моему читателю произвести на него такое же впечатление, какое производит на меня кадетски-наглая в невежестве своем фигура Льва Толстого, постоянно выталкивающая рыло из-за его дивно художественного, несознательного таланта. Глубоко сожалею, что не виделся с Вами, и Бог знает, когда и увижусь, - по мне бы очень хотелось попросить у Вас комментария на Ваши же слова. Что именно следует понимать под оригинальной личной физиономией автора: субъективность ли его в воспроизведении задуманных им характеров, или своеобразие его литературных приемов? Я это не совсем понимаю. А затем крепко жму Вашу руку, дорогой Иван Сергеевич, и остаюсь immorto fide ${ }^{1}$ всегда Ваш Б. Маркевич [И. С. Тургенев. Из неизданной переписки: 295-296].

Сохранилось также недавно опубликованное письмо А. К. Толстого Маркевичу от 27 декабря 1869 г. из Красного Рога, в котором есть отклик на тургеневскую оценку романа:

Тургенев Вам пишет: «Читал с интересом». Он не должен был употребить это выражение, он должен был сказать: читал с участием или, по крайней мере, интересовался чтением. Он еще говорит: «недостаточно видна авторская физиономия». Я далеко не разделяю его мнение, моя жена тоже. Я, напротив, упрекаю Вас в том, что в первой части Вы слишком много показали Вашу физиономию, что Вы были недостаточно объективны, недостаток, который полностью искупается во второй части. $<\ldots>$ Ваш нигилист - лицо, которое живет и дышит, и его дуализм - отличный психологический этюд. Моя жена сама написала бы об этом, но она недомогает и

${ }^{1}$ бессмертно верный (лат.). 
не спит по ночам. Я заключаю из Вашей переписки с Тургеневым, что Ваш роман вышел отдельной книгой, и я требую от Вас, чтобы Вы мне послали один экземпляр с собственноручной подписью. Я недавно его снова прочел в «Русском вестнике», но комплект не полный und habe mich ordentlich verärgert, что вдруг меня das Futter unter dem Maule weggezogen ${ }^{1}$. Мне доставит большое удовольствие перечитать всё с начала до конца [Никё: 224].

Из этих писем очевидно отрицательное отношение Тургенева к роману. Именно «Типы прошлого» положили начало его разрыву и с Маркевичем, и с редакцией «Русского вестника». Но спор Тургенева с Маркевичем отнюдь не ограничился широко известным Ladislas'oм, которым он заклеймил своего противника в романе «Новь».

В этой же «Нови», освещая противоречия в характере Нежданова, Тургенев дает свою оценку «нигилисту» Кирилину. Заметим, что Маркевич открывает в душе своего радикала отмеченное А. К. Толстым драматическое противоречие между художественной одаренностью и политическим темпераментом. Обращаясь к Наденьке, Кирилин говорит:

«Я не гожусь в аскеты: мне мало одной отвлеченной идеи человеческого блага, я не могу пожертвовать ей красотой, искусством, всею эстетическою стороной жизни. Я никак не могу признать, чтобы мне было всё равно жить в венецианском дворце, исписанном кистью Веронезе, или в грязном чулане на Песках, лишь бы сытым быть... - «Разве этого от вас требуют?» - спросила я, всё более и более удивляясь. Он небрежно пожал плечами. - «Попадаются и такие! Они последовательны, - примолвил он, и, как бы против его желания, улыбка пренебрежения скользнула по его губам, - это всё более семинаристы, люди избитые, пришибленные с ранних лет, впроголодь помаячившие свое детство и юность; они потом всю жизнь свою не могут уже иначе мыслить, как чрез фокус желудка. <...> Меня, вопреки моему рассудку, моей воле, влекут краски, линии, звуки, весь этот блеск и цвет старого, сознательно осужденного мною строя жизни. Я не умею быть последовательным, как те люди. Я не могу ненавидеть вас, потому что вы барышня, аристократка...» [Маркевич 1867. 101: 160].

Тургенев подхватывает у Маркевича эту тему. В судьбе Нежданова большую роль играют наследственные качества. Нежданов - полупле-

${ }^{1}$ И мне было очень досадно, что у меня вырвали хлеб изо рта (нем.). 
бей, полуаристократ. От дворянина-отца ему достались в наследство эстетизм, художественная созерцательность и слабохарактерность. От крестьянки-матери, напротив, - плебейская кровь, несовместимая с эстетизмом и слабодушием. В натуре Нежданова идет постоянная борьба этих противоположных наследственных стихий, между которыми не может быть примирения.

Но Тургенев придает этому дуализму в душе Нежданова иной, более радикальный поворот. Кирилин предпочитает умереть, удовлетворяя свою любовную страсть. А тургеневский Нежданов убивает себя не от любви к Марианне, не от мешающей его радикализму художественной одаренности, а от невозможности реализовать на практике свой политический идеал. 


\section{Список литературы \\ Источники}

Аксаков И. С. Стихотворения и поэмы. Л.: Сов. писатель, 1960. 298 с.

Достоевский Ф. М. Полн. собр. соч.: в 30 т. Л.: Наука, 1972-1990.

И. С. Тургенев. Из неизданной переписки с Б. М. Маркевичем и А. П. Философовой // Звенья. Сборник материалов и документов по истории литературы, искусства и общественной мысли XIX века. М.; Л.: ACADEMIA, 1935. Вып. 5. С. 282-303.

Катков М. Н. Отзывы и заметки. Польский вопрос // Русский вестник. 1863. № 3. C. 469-506.

Маркевич Б. М. <Лесницкий Б.> Типы прошлого // Русский вестник. 1867. № 8-12.

Маркевич Б. М. Марина из Алого Рога // Русский вестник. 1873. № 3. С. 200-274.

Маркевич Б. М. Перелом // Русский вестник. 1884. № 5.

Письма Б. М. Маркевича к графу А. К. Толстому, П. К. Щебальскому и др. СПб.: Тип. т-ва «Общественная польза», 1888. 370 с.

Тургенев И. С. Полн. собр. соч. и писем: в 30 т. М.: Наука, 1978-2018.

\section{Исследования}

Андреева В. Г. О национальном своеобразии русского романа второй половины XIX века. Кострома: КГУ, 2016. 492 с.

Гайнцева Э. Г. И. С. Тургенев и «молодая плеяда» писателей «Русского вестника» 1870 - начала 1880-х годов // И. С. Тургенев. Вопросы биографии и творчества. Л.: Наука, 1990. С. 122-150

Головин К. Ф. Русский роман и русское общество. СПб.: Изд. А. Ф. Маркса, 1897. 472 c.

Неведенский С. Катков и его время. СПб.: Тип. А. С. Суворина, 1888. 570 с.

Никё Мишель. Из неизданных писем А. К. Толстого к Б. М. Маркевичу // Известия Самарского научного центра Российской академии наук. Социальные, гуманитарные, медико-биологические науки. 2016. Т. 18. № 1 (2). С. 223-226.

Фёдоров А. В. Алексей Константинович Толстой и русская литература его времени. М.: Русское слово, 2017. 752 с. 


\section{References}

Andreeva, V. G. O natsional'nom svoeobrazii russkogo romana vtoroi poloviny XIX veka [On the National Identity of the Russian Novel of the Second Half of the $19^{\text {th }}$ Century]. Kostroma, KGU Publ., 2016. 492 p. (In Russ.)

Gaintseva, E. G. 'I. S. Turgenev i 'molodaia pleiada' pisatelei 'Russkogo vestnika' 1870 - nachala 1880-kh godov" ["I. S. Turgenev and the 'young constellation' of Writers of the 'Russian Bulletin' of 1870 - early 1880s"]. I. S. Turgenev. Voprosy biografii i tvorchestva [I. S. Turgenev. Issuues of Biography and Creativity]. Leningrad, Nauka Publ., 1990, pp. 122-150. (In Russ.)

Golovin, K. F. Russkii roman i russkoe obshchestvo [Russian Novel and Russian Society]. St. Petersburg, Izdanie A. F. Marksa Publ., 1897. 472 p. (In Russ.)

Nevedenskii, S. Katkov i ego vremia [Katkov and His Time]. St. Petersburg, Tipografiia A. S. Suvorina Publ., 1888. 570 p. (In Russ.)

Nike, Mishel. "Iz neizdannykh pisem A. K. Tolstogo k B. M. Markevichu" ["From Unpublished Letters of A. K. Tolstoy to B. M. Markevich"]. Izvestiia Samarskogo nauchnogo tsentra Rossiiskoi akademii nauk. Sotsial'nye, gumanitarnye, mediko-biologicheskie nauki, vol. 18, no. 1 (2), 2016, pp. 223-226. (In Russ.)

Fedorov, A. V. Aleksei Konstantinovich Tolstoi i russkaia literatura ego vremeni [Alexey Konstantinovich Tolstoy and Russian Literature of His Time]. Moscow, Russkoe slovo Publ., 2017. 752 p. (In Russ.) 


\title{
Спасение для нигилиста: представления Н. Н. Страхова о А. И. Герцене
}

\author{
Исследование выполнено при поддержке \\ Национального фонда социальных наук Китая, проект № 20AAWW004
}

\begin{abstract}
Аннотация: Герцена всегда представляют в первую очередь как аристократа-революционера и поклонника Западной Европы. Однако Герцен достаточно быстро разочаровался в перспективах развития европейской цивилизации, и это поняли и почувствовали некоторые его проницательные современники. Литературный критик Н. Н. Страхов написал объемную статью «Герцен», в которой доказал, что Герцен прошел путь от отчаявшегося нигилиста до приверженца русских культурных традиций. Автор рассматривает статью Страхова, анализирует ход его размышлений, останавливается на философских и мировоззренческих особенностях в произведениях Герцена, которые выделяет критик. В статье показано, что Страхов определяет Герцена как первого литератора, начавшего борьбу с Западом. По мнению автора статьи, это утверждение является не только типичным случаем антизападничества почвенника Страхова, но и отправной точкой саморефлексии в русской культуре второй половины XIX в. В статье также подробно обсуждается влияние статьи Страхова на критику и академическую науку.
\end{abstract}

Ключевье слова: Н. Н. Страхов, А. И. Герцен, литературная критика, культурная идентичность, западничество, нигилизм.

Информация об авторе: Чжу Цзяньган, доктор филологических наук, профессор института иностранных языков и литератур, Сучжоуский Университет, ул. Шизи № 1, район Гусу, 215006 г. Сучжоу, провинция Цзянсу, Китай.

E-mail: pipimao@mail.ru

Дата поступления статьи в редакиию: 11.03 .2021

Дата одобрения статьи рецензентами: 09.06 .2021

Дата публикации статьи: 30.09.2021

Для цитирования: Цзяньган Ч. Спасение для нигилиста: представления Н. Н. Страхова о А. И. Герцене // Два века русской классики. 2021. Т. 3, № 3. С. 52-69. https://doi.org/10.22455/2686-7494-2021-3-3-52-69 


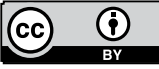

This is an open access article distributed under the Creative Commons Attribution 4.0 International (CC BY 4.0)
Dva veka russkoi klassiki,

vol. 3, no. 3, 2021, pp. 52-69. ISSN 2686-7494

Two centuries of the Russian classics, vol. 3, no. 3, 2021, pp. 52-69. ISSN 2686-7494

Research Article

(C) 2021. Zhu Jiangang

Suzhou University Suzhou, China

\section{The Salvation for a Nihilist: N. N. Strakhov's Ideas About A. I. Herzen}

Acknowledgments: The study was supported by National Social Science Foundation of China, Project no. 20AAWW004.

Abstract: Herzen is always presented primarily as a revolutionary aristocrat and admirer of Western Europe. However, Herzen quickly became disillusioned with the prospects for the development of European civilization, and this was understood and felt by some of his astute contemporaries. Literary critic N. N. Strakhov wrote a voluminous article "Herzen", in which he proved that Herzen went from a desperate nihilist to an adherent of Russian cultural traditions. The author examines Strakhov's article, analyzes the course of his reflections, dwells on the philosophical and worldview features in the works of Herzen, which the critic highlights. The article shows that Strakhov defines Herzen as the first literary man who began the struggle against the West. According to the author of the article, this statement is not only a typical case of anti-Westernism by the nationalist Strakhov, but also the starting point of self-reflection in Russian culture in the second half of the $19^{\text {th }}$ century. The article also discusses in detail the impact of Strakhov's article on criticism and academic science.

Keywords: N. N. Strakhov, A. I. Herzen, literary criticism, cultural identity, Westernism, nihilism.

Information about the author: Zhu Jiangang, $\mathrm{PhD}$ Professor, Suzhou University, no. 1 Street Shizi, District Gusu, 215006 Suzhou, Jiangsu province, China.

E-mail: pipimao@mail.ru

Received: March 11, 2021

Approved after reviewing: June 09, 2021

Published: September 30, 2021

For citation: Jiangang, Zhu. “The Salvation for a Nihilist: N. N. Strakhov's Ideas About A. I. Herzen." Dva veka russkoi klassiki, vol. 3, no. 3, 2021, pp. 52-69. (In Russ.) https://doi. org/10.22455/2686-7494-2021-3-3-52-69 
Herzen is always remembered as an aristocratic revolutionary and Western Europe-worshiper. From the perspective of cultural conflict, however, literary critic N. N. Strakhov wrote a long article "Herzen", prove that Herzen went from a nihilist in despair to a believer of Russian cultural traditions. Based on the "Herzen", author analyzed the entire process of Strakhov's recognition. Strakhov's exploration of religious factors in Herzen's works is further explored. At last, Strakhov define Herzen as the first to fight with the West in Russian literature. In our opinion, this statement is not only a typical case of a critic's anti-westernism, but also the departure point of self-reflection in Russian culture in the second half of the $19^{\text {th }}$ century. Other than that, the impact of this "Herzen" on academia at the time and later is discussed in detail.

In the discussion on the construction of the national image in the Orthodox Church and Russian literature, Nikolai Strakhov's research on Herzen has received little attention but is worthy of attention. Because this not only provides a valuable reference for academic circles to evaluate Herzen as a writer, but also reveals how Russian intellectuals represented by Herzen adhere to the national spirit and beliefs and how they go through a spiritual journey from imagining the West to returning to Russia.

In Strakhov's entire literary criticism heritage, the commentary on Herzen occupies an extremely prominent position. The first volume of the three major volumes of this critic in his later years The Struggle against the West in Our Literature analyzed Herzen in nearly one-third of the length. In 2010, a collection of essays of the same name was published and the editor put Strakhov's long essay on Herzen in a very prominent position, which is much longer than other writers [Strakhov 2010]. However, because of some reasons including documents and ideology (For example his works have not been reprinted in the period of USSR for a long time. And Strakhov himself was regarded as an oppnent of Marxism-Leninism) academic circles at home and 
abroad have paid little attention to this issue ${ }^{1}$. As the American scholar Linda Gerstein, the author of Strakhov's biography, pointed out: "As a writer, his theme is that Russia must be rescued from the rule of Western culture in order to discover its own Individuality" [Linda Gerstein: 102]. In other words, Strakhov's theme is that Russia must get rid of the influence of Western culture and establish its own cultural identity whose characteristic is obviously based on the Orthodox spirit. If we say that Strakhov's several comments on Tolstoy established the writer's status as the embodiment of the national character of Russian literature [Zhu Jiangang]; then his evaluation of Herzen outlines a senior Western European imagining the collapse of the West. This break-up not only forms an important theme in Strakhov's literary criticism: "Struggle against the West in Russian literature", but also reflects Strakhov's final recognition of the uniqueness of Russian culture under the influence of Orthodox civilization.

\section{Strakhov's Discussion on Herzen}

On January 21, 1870, Herzen died in Paris. The news spread to Russia, but there was not much response. Even if it was mentioned, it mostly focused on the political activist Herzen. After all, as a veteran exile, Herzen's golden age has long passed. After the Polish incident in 1863, Herzen and his The Bell fell sharply in popularity among the Russian people because of his support for Polish independence. Herzen recalled in My Past and Thoughts: "By the end of 1863, the circulation of The Bell had dropped from 2500 and 2000 copies to 500 copies, and never exceeded 1000 copies ever since" [Gertsen 11: 374]. However, Herzen is after all a person who left a significant influence on the history of Russian thought and literature. There are still people who are paying attention to and carefully studying his thoughts after the revolution of 1848 in Russia when his thoughts changed. Strakhov is one of them. In the 3,4, and 12 issues of 1870, the Dawn magazine quickly published his long article Herzen ${ }^{2}$ and the full text is divided into three chapters. Ac-

1 The famous scholar Dolinin paid attention to this issue earlier, but only a few words [Dolinin: 226, 334-335]. Later Saratov University professor Antonova also mentioned it in her monographs, but only in Stella Hoff's evaluation of Herzen's early novels [Antonova: 160-169].

2 There are two versions of Strakhov's long essay: one is "Herzen" published 
cording to the separate edition in 1887, it is 168 pages long and entitled as Herzen's Literary Works, Loss of Faith in the West and Struggle with Western Thoughts and the Belief toward Russia. It is easy to see from the title: In Strakhov's interpretation, Herzen has gone from exile to return: that is, attacking Russia - attacking the West - returning to Russia. This process embodies Herzen's gradual understanding of Russian and Western thoughts and his reaffirmation of Russian civilization represented by the Eastern Orthodox civilization. Strakhov interprets it as: "The struggle with European ideas is Herzen's main task and achievement" [Strakhov 2010: 147].

At the beginning of the article, he pointed out many misunderstandings about Herzen: people all regarded him as a political activist, while ignoring his side as a writer. Strakhov positioned Herzen as a "literary and propagandist", and "Herzen is not a simple propagandist; first of all, he is a writer, the holder of famous ideas and opinions and for him, speaking out these thoughts and opinions is the main basic mission. The role of the propagandist is only partly consistent with his views, and most of them are in fierce conflict" [Strakhov 2010]. What needs to be pointed out is: Strakhov first defined Herzen as a writer, but his focus was not on the artistic expression of literature, but on what he called "famous ideas and opinions". Under this premise, the first chapter of Herzen is Strakhov' review of Herzen's main literary works one by one, summarizing Herzen's thought process, and finally it was concluded- Herzen is a pessimist.

Critics start with A Young Man's Memoirs (1840). The focus is on the different views of Goethe between the protagonist and the Polish Terenzynsky, where the author's first sigh of skepticism sounded. Terenzynsky has seen Goethe twice, which is obviously extraordinary for the "me" who admires Goethe. But the fact is just the opposite: Goethe left behind an image of being superior regardless of common people's sufferings. As Strakhov pointed out: “The meaning of the story is consistent with Herzen's many inner desires and is quite diverse. First, there is a denial of authority... Second, there is sympathy on the interest in reality and for living person who is opposite poets and philosophers (the original text is in italics-quotes, the same below)" [Strak-

in the magazine the Dawn in 1870, which has the nature of a eulogy; the other is published in St. Petersburg in 1887. The first volume of the three-volume "Struggle with the West in Our Literature" is titled "Herzen's Literary Activities". This article refers to the latter version. For the convenience of discussion, it is always referred to as "Herzen". 
hov 2010: 13]. In Strakhov's view, Herzen has already aware of the conflict between life and theory: If you emphasize the supremacy of theory, you need to avoid life like Goethe, so that you can achieve the purity of theory; otherwise, it will inevitably lead to suffering, because of the richness of life is not covered by any theory. As Goethe said in Faust: "Theories are all gray, beloved friends, and the golden tree of life is evergreen" [Goethe: 106]. In fact, Herzen's creation just reflects the humanism of the Orthodox Church, which makes thought and theory closer to people's life, showing the humanistic caring of Eastern Orthodox civilization. Although on the surface, Herzen, who emphasizes Western civilization and rationality, seems to be incompatible with Eastern Orthodox thought.

In the analysis of Whose Sin?, Strakhov further pointed out the theme of Herzen's creation: the contingency of life and the absurdity of human nature. For the above theme, Herzen proposed three solutions in About a Drama: First, Stoic formalism; second, religion; third, public interest. What Strakhov admires most is religion: "This plan is obviously the most complete, clearest and most satisfying" [Strakhov 2010: 31]. As Herzen said: "Religion moves to another world and earthly enthusiasm can be hidden in it... Religion is the only and precious way of freedom for humans to control their enthusiasm" [Strakhov 2010: 31]. Religion breaks the isolation of individuals' soul and let their soul combine with the eternal world. However, there is a real society between the eternal world of religion and the spiritual world of individuals. How individuals connect with the eternal world through society is a new problem. This refers to the third point, that is, public interest. Associating individuals with social well-being is a more representative ideological concept since the Enlightenment era. However, in Herzen's era, "everything around is met with skepticism from critics. This is a symptom of the transitional era" [Strakhov 2010: 35]. Everything is changing, including the public interest itself. Therefore, the so-called personal involvement in the public interest was destined to be a purely theoretical solution at that time ${ }^{1}$. Probably because of this, Strakhov said:

\footnotetext{
1 This is like Voltaire's "The Honest Man" finally said that "it's important to grow your own garden"; Faust, which Goethe shaped, finally found the meaning of life in the great cause of transforming nature and reclaiming land from the sea. They all just revealed the theoretical possibility of Enlightenment. Because in the European environment at that time, where could the garden be cultivated freely? Where can the beach be reclaimed from the sea?
} 
"Herzen's formula has a too broad meaning to generalize his personal thoughts" [Strakhov 2010: 35].

Strakhov also analyzed works such as Doctor Krupov, but his main point is still consistent with the above, that is, he summarized in the last section of the first chapter of the paper Herzen's Main Discovery: "What we have analyzed so far is mainly Herzen's literary works, so what is reflected in it is his overall view of life and overall tendency. We think we have clearly proved that the main feature of his tendency is pessimism" [Strakhov 2010: 52].

The second chapter Lost Faith in the West first talks about "what is the West" or the origin of Russian intellectuals imagining the West. Here, Strakhov commented on the issues of Slavophils and Hegelism successively, and in fact introduced the background of the growth of Herzen's thoughts. It is worth mentioning that Strakhov pointed out here: "Among all those who endlessly talk about the West and worship the West, Herzen is a truly mature person who has made an independent evaluation of the West. For Granovsky and Belinsky, the West is a distant world of the other that blends with their own imagination; for Herzen, the West is his homeland, and he talks about it confidently and without cowardice. And he lives in it" [Strakhov 2010: 62]. This made Herzen's Western imagination more authentic and representative in the Russian intellectual circles at that time. However, it was precisely this kind of motherland that dealt Herzen a heavy blow after 1848, which made him feel at a loss. This is particularly evident in his Book of the Other Side while he wrote: "We have studied the decline of Europe for a long time. The mechanism of death is found in all its classes and places and only occasional prophecies are heard from a distance. We also hoped, believed, and worked hard to believe at first. The dying struggle has changed the characteristics one after another so quickly that we can't deceive ourselves. Life is like the last light from the window before dawn, which is gradually extinguishing. We are defeated and terrified. We stand by and watch the terrible results of death. What do we see in the February Revolution? It can be said that we were young two years ago, but now we are old" [Gertsen 16: 116-117]. This should be Herzen's summary of his thoughts over the years and it's not hard to see his pessimistic and even desperate mentality. And this is exactly what Strakhov will reveal below: "As a result, Herzen went to complete despair. This is our first Westernist desperate for the West" [Strakhov 2010: 97]. However, human beings have to survive after all and despair can only promote hope. It is precisely under the persecution of despair that Herzen's 
thoughts have undergone a qualitative change, that is, the title of Chapter Three, The Struggle with Western Thoughts. Belief in Russia.

This chapter is actually the focus of Strakhov's discussion, because he wants to use Herzen's choice to raise the issue of the development path of Russian culture. Therefore, the title of the first section is The Most Essential Question in Our Problem - "Our spiritual uniqueness. Who are we Russians? Are we forming a unique nation in terms of ideology and morality that we can find special elements in our own history to create a special culture? Or should we keep the same proposition and keep everything subject to Europe, just like the relationship between Belgium and France?” [Strakhov 2010: 106]. So, Strakhov talked about Herzen, and he really focused on the uniqueness of Russian culture. Herzen's choice gave the best answer to this question. In his words: "Faith in Russia - saved me on the verge of moral collapse" [Strakhov 2010: 111].

Then, what is the "Russian Faith"? Strakhov explained it with the help of Herzen's From the Other Shore (1851). First of all, he pointed out: “There is no event in Herzen's life more important than this struggle and no book comparable to From the Other Shore among all his works" [Strakhov 2010: 277]. Furthermore, "In the book, Herzen expounds his views on Russian Slavophiles. He notes that Eastern Orthodoxy is superior to Roman Catholicism and that although Russia has been rid of feudalism, its legacy - village communes - still remains" [Strakhov 2010: 27]. In other words, the "Russian Faith" is embodied among others in the superiority of the Orthodoxy and the uniqueness of village communes. When speaking of the Orthodoxy, however, Herzen made a rather vague statement: "I think something existing in Russian life is above society and more powerful than the country itself. Such a thing can't be related by language and is hard to explain. By this, I mean some internal and unnoticed power which has freed Russian people from their sufferings under the rule of the Golden Horde and Germans. It is this internal power that enabled Russian farmers to keep a cheerful personality and an active mind even when they have gone through humiliating oppressions in serfdom. This power also enabled Russian society to respond to Tsar's decrees with the great Pushkin phenomenon even after one hundred years. Last but not least, this power and faith is continually active in our mind" [Strakhov 2010: 278-279].

Herzen didn't mention the Orthodoxy in the book, but it seemed that nothing other than the Orthodoxy could have such a huge impact in the context of 
the evolving history of Russian culture. Or a comparison can be drawn between Herzen's statement and the words of the Orthodox philosopher Sergey Bulgakov (1871-1944) on the Orthodox spirituality: "The holiness this spirituality pursues (Russian people expressed their pursuit in the name 'Holy Russ') is the utmost tolerance and self-sacrifice. $<\ldots .>$ There is an innermost and heroic element in this holiness: the full power of religious will and practice lies in trying to get rid of the natural image of self and wearing the image of Christ" [Wright: 188]. The two thinkers were actually speaking of the same subject with descriptions of the sufferings and the creation of heroic deeds in their writings. Although the Orthodoxy pays less attention to the rites and ceremonies than the Catholicism, its strong spiritual power is the source of strength for Russian people. This ineffable mystery of the Orthodoxy constitutes its characteristics on the one hand, and its superiority over Catholicism on the other: "Among many types of religions, Orthodoxy is characterized by insufficient reality and external manifestations, but because of this, the heavenly truth revealed by Christ gets least distorted" [Wright: 4].

Now that the particularity (or superiority) of the Russian faith is noticed, the answers to the questions: Where is the path forward for Russia? What is the particularity of Russian culture? - are obvious. In his article The Old World and Russia written in February, 1854, Herzen put forward: "The question arises naturally - Should Russia follow all the stages of European development? Or should Russia take a different revolutionary path? I am firmly opposed to its taking the old paths of Europeans. $\langle\ldots\rangle$ Our people don't need to restart such painful efforts at all. Why should they bleed for insolvable problems that we meet and that only give rise to other problems and aspirations?" [Gertsen 16: 186]. Therefore, Herzen concluded that Russia should consider its own reality and take a unique Russian path for its political and cultural construction. Just like the Orthodox cultural thinker Berdyaev (1974-1948) said many years later, Herzen "went out of the Western camp and defended the unique Russian path" [Berdiaev: 66]. This is exactly the purpose of Strakhov in writing the article.

\section{The Way Out for Herzen and Nihilists}

Upon Herzen's death, Petersburg Censorship Committee hastily issued a notice in order to prevent the radical publications from taking the opportu- 
nity to promote Herzen and causing social ideological confusion. The notice read: "If the committee during the censorship finds any articles that express sympathy for the activities of Herzen, a recognized sinner of the state, the committee shall consider them completely unsuitable for publication. The committee will only allow articles stating Herzen's death just as a fact and Herzen's works published in Russia to be published" [Pekar': 110]. Therefore, review articles of Herzen at that time often ended up with criticism on his political activities. However, Strakhov's article is different in that it breaks free from the political fights, not only breaking the rule and referring Herzen's works published abroad, but also interpreting Herzen's thought with great patience. For one thing, the article wants to show the development path Russia should take through Herzen's life experience; for another, it implies the profound thoughts of Strakhov on nihilism. From disillusionment of the West to the return to Russia, these are the two aspects of the same problem. The disillusionment of nihilism would definitely create conditions for returning to Russia. Herzen is a typical representative of nihilism. Therefore, an interpretation of his ideological process would represent the whole process of nihilism from its birth to disillusionment and reveal his spiritual process of returning to Russian civilization based on the Orthodox spirit. In fact, Strakhov has long been paying his attention to nihilism.

In the series of articles Poverty of Our Literature, Strakhov (1868) discussed nihilism - "its existing reasons and power" in a separate section. First, he pointed out the conflict between nihilism and life: "Nihilists deny both Russian life and European life". In the following analysis, Strakhov gradually traced the origin of nihilism: "Nihilism is a kind of Westernism in the first place". "Besides, nihilism is nothing but extreme Westernism that has fully developed and reached its culmination". Furthermore, "nihilism denies all the established lifestyles" [Strakhov 1868: 45-54]. Accordingly, in Strakhov's view, Herzen's nihilism resulted from his extreme worship of Westernism is "pure nihilism". "The negative and pure nihilism constitutes Herzen's ideological tendency to his last breath of life" [Strakhov 2010: 142]. It is fair to say that those critics' grasp of nihilism and of Herzen's illusion of the West is extremely accurate, but just like a doctor's treating a patient, it is not enough to just obtain an accurate diagnosis of the disease but a treatment plan needs to be proposed. This involves the issue of critics and religion.

Scholars have always had split opinions about Strakhov and religion [N. N. Strakhov v dialogakh]. Considering his natural science and hegelian 
background, some scholars believe Strakhov is not a devout worshipper of the Orthodoxy and at most a "religious skeptic". Russian cultural activist Duke Ukhtomsky (1861-1921) recollected: "He has never heard a word relating to religion from Strakhov. He thinks Strakhov is more 'a Voltairean' and 'a thinker of the $18^{\text {th }}$ century' than a religious man" [Luk'ianov: 398]. However, actually, as Strakhov grew up in a church school, a religious complex was deeply ingrained in him. For example, in August, 1886, he wrote in a letter to Tolstoy: "I would rest in peace if I could write another book on how to seek, extol and learn God in every possible way" [L. N. Tolstoi i N. N. Strakhov: 712]. Another more direct proof is that in 1890, Strakhov's student and religious thinker Rozanov (1856-1919) asked Strakhov directly: "Am I right to define your exploration focus of thought, scholarship and literature as religious in my article?" Strakhov answered: "I have no idea how you would write about my religiousness, but of course, you are right, for all serious explorations will eventually lead to religion" [Rozanov 2001: 60]. As Rozanov later concluded, Strakhov's works were centered on Eastern Orthodoxy. "It is just that he is a philosopher-observer, who is afraid of making not only absolute but also direct and detailed conclusions on the issue of faith" [Rozanov 2001: 117]. Apparently, Rozanov's statement is not a conclusive conclusion, but if we look into Strakhov's works, it is not difficult to find that the critic has a very close relationship with religion, and this relationship is naturally reflected in his articles.

Take the above article about Herzen as an example. Strakhov praised Herzen's mention of using religion to deal with contingency and absurdity of life so that he even inserted on purpose in the article a discourse on the image of the soldier Platon Karatayev, a character in Tolstoy's War and Peace, saying: "He represents a vivid solution of the task for which Herzen suffered" [Strakhov 2010: 34]. Strakhov later specifically pointed out: "A few chapters involving Karatayev play an extremely important role in establishing the internal connection of the whole story, almost overshadowing all our literary works depicting the inner and daily life of ordinary people" [Strakhov 1901: 270]. The reason is that Karatayev represents the embodiment of Russian spirit full of characteristics of the Orthodoxy. When depicting Karatayev, Tolstoy wrote he always used the word "peasant" as "Christian". In addition to the little clue and more importantly, Karatayev embodies the factor of "aggregation": In his opinion, his life as an individual phenomenon has no meaning. He is meaningful only when he is a part of the whole that he always feels. His words and 
actions flow out of him, just like the fragrance coming from the secretion of the flower is so uniform, inevitable, and direct. Aggregation emphasizes the achievement of unity through maintenance of individuality. An individual's life is meaningless unless it is integrated into the collective one. In the view of the famous thinker Khomyakov (1804-1860), "This integration is based on the love of God and His truth and the mutual love between those who love God. In Catholicism, there is only unity but no freedom; and in Protestantism, there is only freedom but no unity. What is realized in these religious beliefs is only external unity and freedom" [Lotsky: 31 ]. In the novel, Karatayev is such a spiritual embodiment of aggregation who loves God and truth as well as his companions.

It is true that Karatayev is just the most ordinary soldier in the eyes of others while he is extraordinary to Pierre because the latter has Herzenesque despair. This kind of despair only appears meaningful in contrast with Karatayev's spirit of letting things take their own course and feeling at peace with the world. Therefore, it is under Karatayev's influence that Pierre felt that the world that has been destroyed is now active in his soul with new beauty and on a new unshakable foundation. Isn't this return, in Strakhov's eyes, the best way out for nihilists after the disillusionment of their Western dream?

\section{The Debate about Herzen}

According to archive records, Herzen once put the book censor in St. Petersburg into a dilemma. As far as the content of the article is concerned, there are many banned contents in the article. Instead of criticizing Herzen, this article quoted a large number of Herzen's texts published overseas. But on the other hand, the ultimate goal of Herzen is not to promote Herzen. The article was finally approved by Yelenev (Еленев Ф. П. 18271902) and Fox (Фукс В. Я. 1829-1891), members of the National Publishing Affairs Commission. It should be said that the two have seen the significance of Strakhov's article. For example, Yelenev pointed out that the purpose of the article is to prove that Herzen expressed disappointment in democratic and revolutionary Europe at the end of his literary and political career, and he firmly believed in the national factor in Russian life... Although this view is clearly inconsistent with Herzen's entire activities and is therefore not accurate, the political inclination of this article is not harmful... The Herzen's 
work cited just proves the author's presupposition... [Pekar': 119]. Thanks to the censor's understanding, the article was not subject to official suppression after its publication. However, it should be pointed out that for a long time after the publication of Herzen, the focus of the critics did not fall on the core view of "struggling with the West". Critic, including Dostoevsky and others, have focused more on Herzen as a thinker.

The first to respond to the article was Dostoevsky, who lived abroad. On March 24, 1870, Dostoevsky's letter to Strakhov mentioned the latter's article on Herzen, "I have read the third issue of Dawn with great satisfaction and can't wait for reading its sequels in order to fully understand what is said in it. I have a foreboding that you mainly want to present Herzen as a Western European faction and talk about the West in comparison with Russia, right? You have successfully demonstrated Herzen's main point, pessimism" [The Complete Works of Dostoyevsky 22: 720-721]. Dostoyevsky captured the key point of this article, the relationship between a Western European faction and Russia. However, Dostoevsky did not fully support Strakhov's view. In the same letter, he raised the following question, "By the way (although this is not included in the title of your article), in judging and determining whether the main essence of all Herzen's activities still exists another point of view, which believes he is mainly a poet at all times" [The Complete Works of Dostoevsky 22: 721]. However, Strakhov mentioned in the article that the purpose of his writing was to "recover the meaning of Herzen's literary activities" [Strakhov 2010: 54]. In other words, he wanted to point out the meaning behind the literary activities, that is, the meaning of Herzen's struggle with the West. This is probably something that Dostoevsky did not expect. Because he focuses more on the disconnection between Herzen and the "soil" of his country. "History seems to be destined to show this crack between the majority of our educated class and the people through Herzen, the most distinctive character type" [The Complete Works of Dostoyevsky 19: 8]. Despite the above differences, Dostoyevsky still expressed "extremely satisfaction" and even portrayed a Herzen in The Boy to respond ${ }^{1}$.

Perhaps because of the praise of Dostoyevsky and many friends, Strakhov himself was quite content with this article, so that he took the initiative to recommend it to Tolstoy, "The article about Herzen is the depth of under-

${ }^{1}$ For the relationship between Versilov and Herzen, see: [Dolinin: 104-112]; [Kantor]. 
standing surprised those who knew Herzen and loved him..." [L. N. Tolstoy i N. N. Strakhov: 134]. Compared to Dostoyevsky, Tolstoy emphasized the issue of Herzen's struggle with the West, which is closer to Strakhov's original intention. In 1888, Tolstoy mentioned Herzen in a letter to Chertkov. His views were obviously influenced by Strakhov. "I was reading Herzen and I was very happy but also sad to see his works being forbidden to be published. First, as a writer, even if he is not above, but he is equivalent to our first-class writer; second, if his works have become inseparable in the thinking of the younger generation since the 1850s, then we won't have any revolutionary nihilists. To prove that the revolutionary theory is baseless, just read Herzen, just like all violence can only be denied with the purpose of violence" [Tolstoy 86: 121-122]. Herzen is the antidote to the theory of Western revolution for Russian society. This understanding is exactly the same as the viewpoint put forward by Strakhov in the article. Victor Shklovsky saw this in his biography of Tolstoy, "According to Tolstoy, Herzen is important because he is a person who struggles with the 'Western European Revolutionary Theory'. This is an explanation of Tolstoy. He wanted to turn Herzen into his fellow traveler" [Shklovsky: 583].

Throughout the Soviet period, Herzen researchers rarely mentioned this long article by Strakhov. In 1922, Dolinin (Долинин А. С. 1880-1968) wrote Dostoevsky and Herzen, which involved Strakhov's evaluation of Herzen, but it was also very few. Even if other Herzen researchers mentioned it occasionally, they all believed that Strakhov had exaggerated Herzen's pessimism ${ }^{1}$ too much. Because according to Lenin's tone, despite Herzen's many shortcomings, he is after all "a figure of the generation of aristocratic landlords and revolutionaries in the first half of the nineteenth century" [Lenin: 125]. It is obviously not conducive to shape Herzen as a revolutionary if completely attribute it to "pessimism". In addition, Marxism is also a theory from Western Europe. If Strakhov's attempt to fight against it with the help of traditional Orthodox ideology, isn't him a complete reactionary for those Soviet academic authorities? However, Linda Gerstein, who is far across the ocean, pointed out the uniqueness of Strakhov's article. In the biography mentioned at the beginning of this article, Gerstein not only pointed out that "For Rus-

1 "Herzen's pessimistic remarks are too much in Strakhov's discourse and turned into the main characteristic of his thought" [Gillel'son, Dryzhakova, Perkal': 86]. 
sians, Herzen is a perfect example of 'struggle with the West"', he also believed that "Strakhov is the first someone who sees the Slavist side of Herzen" [Linda Gerstein: 128]. On this basis, one of the older generations of scholars Tunimanov commented on Herzen justly. "This work of Strakhov is the most talented and most distinctive work of critics. Strakhov has every right to be proud of his articles about Herzen and his contemporaries' response..." [Tunimanov: 104]. But that was happened in 1987.

After entering the $21^{\text {st }}$ century, Russian social conservatism has reemerged, and Strakhov has entered the reader's field of vision with his clear anti-Western stance. In 2010, the collection of essays published by the Russian Academy of Civilization was named "Struggle with the West" and the main article was Herzen, which fully reflects Russian ideological circle's recognition for Strakhov's article.

\section{Conclusion}

As stated at the beginning of this article, Strakhov used Herzen as a model, trying to discuss a senior Western faction imagining the collapse of the West. Because it is "collapse", the article Herzen does not actually put forward too many constructive conclusions. For Strakhov, Herzen's thought shift is just an introduction. The article focuses on the formation process, reasons and eventual disillusionment of Herzen's imagination of the West. As for what happens after the turn, Strakhov only briefly involved here, without further elaboration. The $20^{\text {th }}$-century religious philosopher Vasiliy Zinkovsky (Зеньковский В. В. 1881-1962) said Strakhov has just walked halfway towards this goal after all, which is not unreasonable. He first appeared in the "foundation" of mysticism, and he has become more and more attuned to the remnants of rationalism" [Zinkovsky: 458]. What is "foundation"? It is a question that could be discussed separately. But it is certain that the foundation must contain the Orthodox element. In Zinkovsky's view, although Strakhov did not become a devout believer (walking "half the way"), as mentioned above, his thoughts undoubtedly included many elements of the Orthodox Church. From the perspective of his writing style, the incompleteness or openness of this ideological discussion also constitutes Strakhov's consistent style of literary criticism, just as Rozanov pointed out: "A brief discussion, a summary, or as he used to name his article twice, the 'at- 
tempt to ask the question correctly' - this is the most common and most convenient way to express his thoughts" [Rozanov 2000: 12-13].

From today's point of view, Strakhov's turn towards Herzen is inevitably "over-interpreted". For example, the understanding of Orthodox Church and the identification of Slavic ideas may not be consistent with Herzen's expression in The Past and Thoughts. But the reason is obviously not only Strakhov's theme coming first. You must know that Herzen himself is a rather contradictory person. The contradictory expressions of certain issues in different periods can be seen as the manifestation of the complex personality of the thinker, or as the constant self-denial and self-development of his own thoughts. Influenced by the failure of the revolution in 1848, Herzen lost confidence in Western Europe and turned his hopes on Russian villages.

From this perspective, Strakhov mainly emphasized the Russianness (more precisely, the Orthodox factor) in Herzen's thought transition in his later years. In fact, he grasped the core part of his life's thoughts, which can be described as one-sided profound. It contrasts with the revolutionary mentor's understanding of Herzen's "anti-liberalism" from a revolutionary perspective. With regard to Strakhov's cognition, the $20^{\text {th }}$-century thoughts of Sher Bulgakov, Zenkovsky, etc., everyone recognized it, “...Herzen is a religious thinker, because for religious orientation (and only for it), theory and value factors are intrinsically inseparable in the understanding of existence. Therefore, when studying Herzen, we should start from analyzing his religious consciousness and religious ideals, deriving and reconstructing its ideological system" [Zen'kovskiy: 274]. Finally, although in Strakhov's ideological exploration career, Herzen is only one of his periodic achievements in reflecting on the Russian nation's cultural characteristics and shaping the national image of Russia. However, from today's perspective, breaking the blind worship for Western culture and building a culture with national characteristics on the soil of the whole country is also a practical reference of great significance for the rising China.

\section{Список литературы \\ Источники}

Бердяев Н. А. Русская идея: Основные проблемы русской мысли ХІХ в. и начала XX в. Париж: YMCA-press, 1971. 258 c.

Гериен А. И. Полн. собр. соч.: в 30 т. / Акад. наук СССР. Ин-т мировой литературы им. А. М. Горького. М.: АН СССР, 1954-1966. 
Зеньковский В. В. История русской философии. М.: Акад. проект: Раритет, 2001. $878 \mathrm{c}$

Л. Н. Толстой - Н. Н. Страхов: Полное собрание переписки в 2 т. Kanada, Slavic Research Group at the University of Ottawa; Moscow, State L. N. Tolstoy Museum, 2003. T. 2.600 p.

Розанов В. В. Литературные изгнанники: Воспоминания. Письма. М.: Аграф, 2000. $360 \mathrm{c}$.

Розанов В. В. Литературные изгнанники. Н. Н. Страхов, К. Н. Леонтьев / под общ. ред. А. Н. Николюкина. М.: Республика, 2001. 475 с.

Страхов Н. Н. Бедность нашей литературы. СПб.: Тип. Н. Неклюдова, 1868. 73 с.

Страхов Н. Н. Борьба с Западом / сост. и комм. А. В. Белова, отв. ред. О. Платонов. М.: Ин-т русской цивилизации, 2010. 576 с.

Страхов H. Н. Борьба с Западом в нашей литературе: Исторические и критические очерки. Киев: Тип. И. И. Чоколова, 1897. Кн. 1. 386 с.

Страхов Н. Н. Критические статьи об И. С. Тургеневе и Л. Н. Толстом. Киев: Тип. И. И. Чоколова, 1901. 387 с.

The Collected works of L. N. Tolstoy. Trans. Liuliaoyi, Beijing: People's Literature Publishing House, 2000.

The Complete works of F. M. Dostoevsky, Chief ed Chen Shen. Shijiazhuang, Hebei Educaitional publishing house, 2010.

Lossky, N. O. A philosophy history of Russia. Trans. Jiazelin and others, Hangzhou, Zhejiang people's publishing house, 1999. $416 \mathrm{p}$.

\section{Исследования}

Антонова Г. Н. Герцен и русская критика 50-60-х годов XIX века. Проблемы художественно-философской прозы. Саратов: Изд-во Сарат. ун-та, 1989. 198 с.

Гиллельсон М. И., Дрыжакова Е. Н., Перкаль М. К. А. И. Герцен. М.; Л.: Просвещение, 1965. 340 с.

Долинин А. С. Последние романы Достоевского. М.; Л.: Сов. писатель, 1963. $344 \mathrm{c}$.

Кантор В. К. Трагические герои Достоевского в контексте русской судьбы (Роман «Подросток») // Вопросы литературы. 2008. № 6. С. 119-151.

Лукьянов С. М. Запись бесед с Э. Э. Ухтомским // Российский Архив. М.: Студия ТРИТЭ: Рос. архив, 1992. Вып. II-III. С. 393-402.

Н. Н. Страхов в диалогах с современниками. Философия как культура понимания / ред. С. М. Климова. СПб.: Алетейя, 2010. 207 с.

Пекарь М. К. Отклики русской печати на смерти А. И. Герцена // Общественная мысль в России ХІХ в. Л.: Наука, 1986. С. 108-126.

Туниманов В. А. «Вольное слово» А. И. Герцена и русская литературная мысль XIX века // Русская литература. 1987. № 1. С. 100-112.

Goethe, Johann Wolfgang von. Faust. Berlin; Weimar: Aufbau-Verl., 1986. 783 p.

Jiangang Zhu. Life Consciousness and National Foundation: A Brief Discussion on Strahov's Interpretation of Tolstoy // Foreign Literature Review. 2014. No. 1. P. 143-155. 
Gerstein L. Nikolai Strakhov. Cambridge: Harvard University Press, 1971. 233 p.

Shklovsky V. Tolstoy. Trans. An Guoliang and others. Zhengzhou: Swollow publishing house, $2005.795 \mathrm{p}$.

Wright A. C. Mikhail Bulgakov: Life a. interpretations. Toronto etc.: University of Toronto press, Cop. 1978. 324 p.

\section{References}

Antonova, G. N. Gertsen i russkaia kritika 50-60-kh godov 19 veka. Problemy khudozhestvenno-filosofskoi prozy [Herzen and Russian Criticism of the 1850-1860s. Fiction and Philosophical Prose Issues]. Saratov, Saratov State University Publ., 1989. 198 p. (In Russ.)

Gillel'son, M. I., Dryzhakova, E. N., Perkal', M. K. A. I. Gertsen [A. I. Herzen]. Moscow, Leningrad, Prosveshchenie Publ., 1965. 340 p. (In Russ.)

Dolinin, A. S. Poslednie romany Dostoevskogo [The Last Novels of Dostoevsky]. Moscow, Leningrad, Sovetskii pisatel' Publ., 1963. 344 p. (In Russ.)

Kantor, V. K. "Tragicheskie geroi Dostoevskogo v kontekste russkoi sud'by (Roman 'Podrostok')" ["Dostoevsky's Tragic Heroes in the Context of Russian Destiny (Novel Teenager)"]. Voprosy literatury, no. 6, 2008, pp. 119-151. (In Russ.)

Luk'ianov, S. M. "Zapis' besed s E. E. Ukhtomskim" ["Recording of Conversations with E.E. Ukhtomsky"]. Rossiiskii Arkhiv [Russian Archives] issue II-III. Moscow, Studiia TRITE, Ros. arkhiv Publ., 1992, pp. 393-402. (In Russ.)

Klimova S. M., editor. N. N. Strakhov v dialogakh s sovremennikami. Filosofiia kak kul'tura ponimaniia [N. N. Strakhov in Dialogues with Contemporaries. Philosophy as a Culture of Understanding]. St. Petersburg, Aleteiia Publ, 2010. 207 p. (In Russ.)

Pekar, M. K. "Otkliki russkoi pechati na smerti A. I. Gertsena" ["Responses of the Russian Press on the Death of A. I. Herzen"]. Obshchestvennaia mysl' $v$ Rossii XIX v. ["Social Thought in Russia in the $19^{\text {th }}$ Century"]. Leningrad, Nauka Publ., 1986, pp. 108-126. (In Russ.)

Tunimanov, V. A. "Vol'noe slovo' A. I. Gertsena i russkaia literaturnaia mysl' XIX veka". ["Free Speech' of A. I. Herzen and Russian Literary Thought of the $19^{\text {th }}$ Century"]. Russkaia literatura, no. 1, 1987, pp. 100-112. (In Russ.)

Goethe, Johann Wolfgang von. Faust. Berlin, Weimar, Aufbau-Verl., 1986. 783 p. (In German)

Jiangang Zhu. "Life Consciousness and National Foundation: A Brief Discussion on Strahov's Interpretation of Tolstoy." Foreign Literature Review, no. 1, 2014, pp. 143-155. (In Chinese)

Gerstein, Linda. Nikolai Strakhov. Cambridge, Harvard University Press, 1971. 233 p. (In English)

Shklovsky, V. Tolstoy. Trans. An Guoliang and others. Zhengzhou, Swollow publishing house, 2005. 795 p. (In Chinese)

Wright, Anthony Colin. Mikhail Bulgakov: Life a. interpretations. Toronto etc.: University of Toronto press, Cop. 1978. 324 p. (In English) 


\section{Александр Невский или Александр Свирский: к вопросу о небесном покровителе А. Н. Островского}

Аннотация: Статья посвящена практически не изученной в литературе об А. Н. Островском проблеме, связанной с небесным покровителем драматурга. Традиционно к такому покровителю относят святого благоверного великого князя Александра Невского. Основой для подобного соотнесения служит день 30 августа. В этот день были перенесены мощи Александра Невского из Владимира в Петербург, и в этот же день Островский в обязательном порядке праздновал именины в своей усадьбе в Щелыково. Автором статьи обращается внимание, что при крещении Островского самым близким по времени Александром был святой преподобный Александр Свирский, в честь которого и мог получить имя будущий драматург. Отмечаются обстоятельства, сопутствующие обретению имени Александр: письмо самого драматурга к дяде священнику П. Ф. Островскому, некоторые значимые характеристики из биографии этого родственника драматурга. Далее проводятся сопоставления сначала эпизодов из жития, канона и акафиста преподобного Александра Свирского, а затем великого князя Александра Невского с жизнью и творчеством Островского. В итоге автор статьи приходит к выводу, что преподобный Александр Свирский вполне может считаться небесным покровителем Островского. Хотя данное заключение не исключает дискуссионности.

Ключевъе слова: А. Н. Островский, великий князь Александр Невский, преподобный Александр Свирский, именины, житие, канон, акафист, жизнь, творчество.

Информация об авторе: Ирина Анатольевна Едошина, доктор культурологии, профессор, Костромской государственный университет, ул. Дзержинского, д. 17, 156000 г. Кострома, Россия. ORCID ID: http://orcid.org/0000-0002-4265-3611

E-mail: tettixgreek@yandex.ru

Дата поступления статьи в редакиию: 14.04 .2021

Дата одобрения статьи рецензентами: 29.06 .2021

Дата публикации статьи: 30.09.2021

Для цитирования: Едошина И. А. Александр Невский или Александр Свирский: к вопросу о небесном покровителе А. Н. Островского // Два века русской классики. 2021. T. 3, № 3. C. 70-83. https://doi.org/10.22455/2686-7494-2021-3-3-70-83 


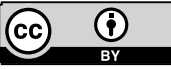

This is an open access article distributed under the Creative Commons Attribution

4.0 International (CC BY 4.0)
Dva veka russkoi klassiki,

vol. 3, no. 3, 2021, pp. 70-83. ISSN 2686-7494

Two centuries of the Russian classics, vol. 3, no. 3, 2021, pp. 70-83. ISSN 2686-7494

Research Article

(C) 2021. Irina A. Yedoshina

Kostroma State University Kostroma, Russia

\title{
Alexander Nevsky or Alexander Svirsky: On A. N. Ostrovsky's Patron Saint
}

\begin{abstract}
The article is devoted to the issue of A. N. Ostrovsky's patron saint, practically unexplored in literature. Traditionally, his patron saint is believed to be the holy blessed Grand Duke Alexander Nevsky. The basis for this correlation is the day of August 30. On this day the relics of Alexander Nevsky were transferred from Vladimir to St. Petersburg, and on the same day Alexander Ostrovsky necessarily celebrated his name day in his estate of Shchelykovo. The author of the article draws attention to the fact that the holy Reverend Alexander Svirsky was the closest saint to the time of Ostrovsky's christening, and the future playwright could be named in his honor. The circumstances accompanying the acquisition of the name Alexander are noted: a letter from the playwright to his uncle, priest P. F. Ostrovsky, some significant characteristics from the biography of this relative. The author compares episodes from the life, canon and acathistus of St. Alexander Svirsky, and then Grand Duke Alexander Nevsky with the life and work of Ostrovsky. As a result, the author concludes that Reverend Alexander Svirsky may well be considered Ostrovsky's patron saint. Nevertheless, this conclusion does not exclude controversy.
\end{abstract}

Keywords: A. N. Ostrovsky, Grand Duke Alexander Nevsky, Reverend Alexander Svirsky, name day, life, canon, acathistus, biography, creativity.

Information about the author: Irina A. Yedoshina, DSc of Culturology, Professor, Kostroma State University, Dzerzhinsky St. 17, 156005 Kostroma, Russia. ORCID ID: http:// orcid.org/0000-0002-4265-3611

E-mail: tettixgreek@yandex.ru

Received: April 14, 2021

Approved after reviewing: June 29, 2021

Published: September 30, 2021

For citation: Yedoshina, I. A. "Alexander Nevsky or Alexander Svirsky: On A. N. Ostrovsky's Patron Saint." Dva veka russkoi klassiki, vol. 3, no. 3, 2021, pp. 70-83. (In Russ.) https:// doi.org/10.22455/2686-7494-2021-3-3-70-83 
Традиционно считается, что именины А. Н. Островского связаны со святым благоверным великим князем Александром Невским (12201263), чему в немалой степени способствовало советское время. В 1938 г. на экраны выходит фильм «Александр Невский» С. М. Эйзенштейна. В основу фильма положены военные события, что соответствовало советской идеологии, построенной на поиске и уничтожении врагов. А Островского в это время рассматривали преимущественно как борца с «темным царством» (Н. А. Добролюбов). Ранее Эйзенштейн обращался к творчеству драматурга: известны его эскизы декораций (1920) к «Василисе Мелентьевой», а также постановка спектакля-клоунады «Мудрец» (1923) на сцене театра Пролеткульта по мотивам пьесы «На всякого мудреца довольно простоты».

Внешней причиной, способствующей видению в Александре Невском покровителя Островского, было обязательное празднование драматургом своих именин в Щелыкове 30 августа. По старому стилю в этот день, по Святцам, отмечалось перенесение мощей Александра Невского. Однако не все так просто и однозначно, на что впервые обратила внимание С. Н. Кайдаш-Лакшина [Кайдаш-Лакшина].

Родители драматурга, Николай Федорович (1796-1853) и Любовь Ивановна (? - 1831) Островские, жили в Москве, снимая трехкомнатную квартиру у диакона Никифора Максимова (? - ?), который проживал со своим семейством этажом выше и служил в близлежащем пятиглавом деревянном храме Покрова Богородицы в Голиках (XVII в., снесена в 1931 г.). Возможно, квартиру эту в доме между Малой Ордынкой и Голиковским переулком нашел свояк Островских - диакон храма Климента папы Римского (сер. XVII в.) Александр Иванович Бессонов/Безсонов (? - ?). С другой стороны, женой Н. Ф. Островского стала сестра его приятеля Матвея Савина/Саввина (? - ?) - Любовь. По рождению Матвей и Любовь происходили из семьи просвирни и пономаря Покровской церкви, что также могло 
быть причиной поселения молодой семьи в доме Бессонова/Безсонова.

У родителей будущего драматурга первые двое детей умерли еще во младенчестве: Федор (1820-1821), Матвей (1822-1822). А ранним утром 31 марта (по ст. стилю) 1823 г. у них вновь рождается сын. Младенца крестят 4 апреля (по ст. стилю) в Покровской церкви. Восприемниками при крещении были люди невысоких званий: титулярный советник (9-й чин в Табели о рангах) Иван Иванович Борисоглебский (? - ?) и надворная советница (7-й чин в Табели о рангах, переходящий к жене после смерти мужа) Мария Андреевна Прокудина (? - ?) [Модзалевский: 257]. В аспекте заявленной в статье темы любопытной представляется интерпретация крещения будущего драматурга, обнаруженная в сетях: «В день крещения отец рассказал священнику о своем горе (умирающих детях. - И. Е.) и заявил, что, на его взгляд, жизни и здоровью мальчика ничего не будет грозить, если его нарекут Александром, что в переводе с греческого означает “защитник жизни”, а небесным покровителем ребенка станет святой Александр Невский. Батюшка внял доводам родителя, и будущий гениальный драматург был крещен вопреки святцам (день памяти Александра Невского - 30 августа)» [Алексеев]. Весьма вольная интерпретация крещения будущего драматурга указывает на Александра Невского «вопреки святцам», что, конечно, было просто невозможно для людей, кровно связанных с церковной средой, с детских лет впитавших веру как основу жизни. Однако для поставленной в статье проблемы это «вопреки святцам» сродни оговорке по Фрейду.

О том, почему его назвали Александром, можно узнать от самого драматурга: «Кстати, расскажу Вам, по какому случаю меня назвали Александром. Когда покойная матушка, Любовь Ивановна, написала брату своему, отцу Михаилу, кажется, в Смоленск, о смерти второго сына своего Федора и сетовала, что у нее дети не живут, он отвечал ей, чтобы она, если родится третий сын, назвала его Александром и что Александр (не знаю, уж по каким соображениям) должен жить. Так и случилось. Это мне рассказывал отец, а также и о том, как возили меня в Смоленск к отцу Михаилу напоказ и за благословением» [Островский 11: 399].

По своей природе Островский был человеком закрытым, впускавшим в свой внутренний мир очень ограниченное число людей, тем 
интересней человек, которому процитированное письмо было послано. Это дядя драматурга по отцу - священник П. Ф. Островский (1806/7-1876). Он жил в Костроме и являлся протоиереем Успенского кафедрального собора (XVI в., неоднократно перестраивался, взорван в 1934 г., в настоящее время восстанавливается). Его перу принадлежит по сей день не утратившая историко-культурной ценности книга «Историческое описание Костромского Успенского кафедрального собора» (1855). Островский Павел Федорович жил в Костроме недалеко от храма Иоанна Богослова (XIX в., современный планетарий) на ул. Богословской (современная Горная), в д. 8 (сохранился). В знак признания его заслуг священник Павел Островский будет похоронен в Богоявленском кафедральном соборе в Костроме.

Дядю и племянника связывали добрые отношения, Островский не раз бывал у него в гостях. А крещен П. Ф. Островский, как и отец драматурга, был в Костроме в Благовещенской церкви (XVIII в.), что на ул. Никольской (современная Свердлова). Настоятелем церкви являлся дед Островского - священник Феодор Островский. В 1929 г. храм был закрыт, частично разрушен, использовался как хлебозавод. Ныне восстанавливается.

Итак, летом 1872 г., будучи по обыкновению в своем имении Щелыково, драматург в письме к дяде сообщает причину своего именования. В XIX в., особенно в семьях, тесно связанных со священством, традиционно днем рождения считался тот день, в который ребенка крестили, и он получал имя своего небесного покровителя. Островский был крещен 4 апреля. Александр Невский родился 13 мая 1221 г. в г. Переславль-Залесский, где увековечен в памятнике перед Спасо-Преображенским собором (XII в.). Храмовая икона - «Преображение Иисуса Христа пред учениками на горе Фавор» (XV в.) хранится ныне в Третьяковской галерее в Москве. По дате своего рождения Александр Невский никак не может быть поименован небесным покровителем Александра Островского при его крещении.

Зато ближайшим по Святцам к дню крещения Островского 4 апреля - с именем Александр было 16 апреля (по ст. стилю) - обретение мощей святого преподобного Александра Свирского (14481533). И еще одна любопытная подробность. Александр Невский при постриге принял имя Алексий, человек Божий. Послушник Амос был пострижен в монахи 26 августа 1474 г. с именем Александр, получив 
позднее прозвище Свирский по реке Свирь, в шести верстах от которой построил себе небольшую келью. Он проживет в ней семь лет, не видя лица человеческого, неприхотливо питаясь скудными дарами леса. И здесь обнаруживается одно любопытное географическое пересечение деятельности Петра с жизнью Александра Свирского. Как пишет историк С. М. Соловьев, «надобно было строить новый флот, и на берегах Свири кипела работа, ронили громадные деревья» [Соловьев: 515].

Остается 30 августа (по ст. стилю) - день, когда драматург в обязательном порядке отмечал в Щелыкове свои именины, собирая многочисленных гостей. В Святцах этот день связан с перенесением мощей Александра Невского, который умер 2 ноября (по ст. стилю) 1263 г. в Городце и был похоронен в Богородице-Рождественском мужском монастыре (XII в.) города Владимир. А перенесение его мощей связано опять-таки с Петром I. Кстати, есть еще одна дата, близкая к дню крещения драматурга и также связанная с Петром: 5 апреля (по ст. стилю) 1242 г. на льду Чудского озера произошла битва между новгородцами под предводительством Александра Невского и рыцарями Тевтонского ордена. Александр Невский разгромил немецких рыцарей. Битва вошла в историю под именем Ледового побоища. Но к Святцам дата сия никакого отношения не имеет в отличие от 30 августа.

В этот день в 1721 г., после продолжительной и изнурительной войны со шведами, Петр I заключил Ништадский мир и решил освятить его перенесением мощей благоверного князя Александра Невского из Владимира в новую, северную, столицу - Петербург, основанную на берегах Невы. Вывезенные из Владимира в августе 1723 г. святые мощи были доставлены в Шлиссельбург и оставались там до 30 августа (по ст. стилю) 1724 г. В этот день были перенесены в Троицкий собор Александро-Невской Лавры, где почивают поныне. Указом Петра от 2 сентября 1724 г. 30 августа (по ст. стилю) названо празднованием перенесения мощей Александра Невского и занесено в Святцы. Подчеркнем - Указом, а вовсе не житийной историей, потому вполне закономерно, что в 1727 г. празднество было отменено по причине борьбы разных придворных группировок, а затем, в 1730 г., вновь восстановлено. Не случайно и перенесение мощей в столицу не отменило прежний памятный день - захоронение Александра Невского во Владимире, приходящееся на 23 ноября (по ст. стилю). Этот день отмечался при 
обязательном присутствии членов царствующей династии, всегда торжественно обставлялся и почитался днем памяти благоверного князя Александра Невского.

Приведенные факты были известны драматургу, который хорошо знал русскую историю, общался с М. П. Погодиным и Н. И. Костомаровым, читал Н. М. Карамзина, писал пьесы на исторические сюжеты, о зарождении русского театра в том числе. Сведениями о том, как воспринимал личность Петра I Островский, мы не располагаем, но он мог знать хотя бы из того же Костомарова об отношении Петра к театру: «Театра Петр не любил, хотя и не преследовал его, зная, что его допускают и покровительствуют в европейских государствах. Театр при Петре существовал в Москве в самом жалком виде», но при этом Петр «любил всякие торжества, празднества и восхваления собственных подвигов» [Костомаров III: 745]. По всем указанным причинам можно предположить, что менее всего сам Островский связывал 30 августа с Александром Невским, что, конечно, никак не свидетельствует о его пренебрежении к прославленному имени.

И вот тут мы подходим к самому главному. 30 августа (по ст. стилю), по Святцам, праздновался день памяти святого преподобного Александра Свирского. Это его основной, главный праздник. Таким же этот день воспринимал Островский, что также позволяет соотнести его имя Александр с преп. Александром Свирским. Имя это, по ономатологии священника Павла Флоренского, «самое гармоничное, самое внутри себя пропорциональное» [Флоренский: 30].

По характеру Островский не был воинственен, он старался, насколько возможно, избегать выяснения отношений. А если ему наносили обиду, просто прекращал общение, при этом сохраняя внешние приличия. Закрытость и не публичность, как уже отмечалось, были его характерными чертами. И здесь стремление к уединению, свойственные преп. Александру Свирскому, как нельзя близки драматургу.

Следы высказанного нами предположения можно обнаружить в жизни и творчестве драматурга при соотнесении с житием преп. Александра Свирского, его Акафистом и Каноном.

Вот начало жития будущего Александра Свирского: «Святой был рожден в 1448 году во владениях Великого Новгорода, в селе Мандера, около Островского (курсив мой. - И. Е.) монастыря Пресвятой Богородицы» [цит. по: Владимирова: 4]. Позднее и его родители примут 
постриг «в Островском (курсив мой. - И. Е.) Введенском монастыре, где некогда Васса молилась о рождении сына» [Владимирова: 10]. Как видим, топоним «Островский» связан и с молитвой о рождении будущего святого, и с местом его рождения. Так, мистическим образом задолго до появления драматурга на свет его фамилия уже присутствовала в житии будущего святого Александра Свирского.

В его житии есть сюжет, связанный с купиом, которого преп. Александр Свирский обличал в мздоимстве и призывал проявить милость к бедным, страждущим. Речь его произвела на купца сильнейшее воздействие, его страшно удивило, что Александр все знает о его тайном грехе: «большой непорядочности в торговых делах». Купец исповедует свои грехи, попросит наставления и молитв святого, изменит свою жизнь. В итоге станет «чадом преподобного Александра», позднее оставит мир и примет монашеский постриг. Возможно, именно этот сюжет из жития преп. Александра Свирского станет для Островского той путеводной звездой, что позволит ему никогда не писать купцов только в темных тонах, всегда оставляя им возможность искупления, изменения своей жизни, постижения собственной неправоты. Уже в первой «большой» пьесе Островского «Свои люди - сочтемся!» Самсон Силыч Большов понимает в финале, в какую бездну он погрузил свою собственную жизнь и жизнь близких ему людей. Бездушная, расчетливая Липочка его прямое порождение. Ужас охватывает купца и со словами о Боге он уходит в свое узилище. Но в пьесах Островского есть образованные купцы типа Василькова в «Бешеных деньгах» или Прибыткова в «Последней жертве». Они не сорят деньгами, умеют их считать, использовать на благо не только себя, но и общества. А главное - эти купцы умеют ценить прекрасное, вызывать уважение окружающих, хотя по уровню образования могут уступать европейским торговцам.

Именно с купечеством связывал Островский развитие в Москве театрального искусства. В частности, он замечает: «Русский театр в Москве главным образом нужен для купцов, купцы его и выстроят; они будут в нем хозяевами, они знают, что им нужно, они поведут свое дело безукоризненно, руководствуясь единственно патриотическим желанием видеть процветание драматического искусства в своем отечестве» [Островский 10: 142]. И драматург не ошибся. Купец из семейства Алексеевых возьмет псевдоним Станиславский, станет вдохновителем и создателем первого в России общедоступного художественного 
театра, разработает основы актерского мастерства, что получит в итоге именование «система Станиславского» в России и «метод Станиславского» за границей. Его труд по сей день является основополагающим в подготовке актеров, за рубежом в том числе.

В некоторых строках из Акафиста преп. Александру Свирскому словно открывается жизнь драматурга. В икосе втором сказано: «Рaдуйся, бдением и труды плоть твою духови покоривый». Островскому, конечно, не были чужды страсти телесные, но, став отцом многочисленного семейства, он погрузится в труды писательские, забиравшие все его силы. С любимым Щелыковым, где драматург много работал, вполне соотносимы начальные строки из пятого кондака, где говорится о светозарном луче, озарившем в темноте место пустынное, знаменуя «светлость души» и «пламенеющее сердце».

В шестом икосе речь идет о наставлении многих душ человеческих. По Островскому, театр в силу своей демократичности, доступности всем слоям населения захватывает душу властной рукой, совершая культурную прививку.

В девятом икосе сказано: «...радуйся, тайная согрешения человеческая обличивый». Как уже отмечалось, Островский никогда не был обличителем человеческих пороков, скорее, он на них указывал, давая человеку возможность осознать порочность своих деяний, чтобы как, например, в «Сердце не камень», сказать в финале: «...я должен благодарить Бога, что нашел человека, который знает, на что богатым людям деньги даны и как богатому человеку проживать их следует, чтоб непостыдно мог стать он перед последним судом» [Островский 5: 144]. Островскому, как человеку думающему, гораздо ближе то, о чем сказано в кондаке десятом, с кротостью обличать, с любовью увещевать.

Обнаруживаются параллели с жизнью и творчеством драматурга в Каноне преподобному Александру Свирскому. В Каноне человек обращается не только к Богу, но и беседует с самим собой, со своей совестью, со своей душой, он анализирует свою жизнь и сокрушается о совершенных ошибках. В указанном Каноне - когда речь идет об изнуренном в труде теле (3: 8), огне искушений и страстей (5). Островский и трудился много, изнуряя тело (каждый год по пьесе, а то не по одной), и как человек театрального закулисья познал много любовных страстей.

В икосе 8-го гласа кондака сказано: «...вся Российская земля, тобою 
обогащшися, хвалит тя ... радуйся, отечеству твоему похвала». Эти слова вполне могут быть отнесены к Островскому, чье творчество послужило основой для создания русского театра.

Наконец, еще одно наблюдение: в четвертом гласе стихиры есть выражение «пучина чудес». Драматургом написана пьеса «Пучина». Традиционно, особенно в советское время, это именование соотносят с негативным содержанием, которое легко обнаруживается, например, в «Толковом словаре русского языка» С. И. Ожегова [Ожегов: 984]. Но если, учитывая контекст размышлений, обратиться к «Полному церковнославянскому словарю» прот. Г. Дьяченко, то выяснится, что «пучина» обозначает просто «море» или «открытое море» (Исх. 15: 5), а значения прилагательного «чудесный» - «дивный, великолепный, торжественный» (Авг. 16, п. 8, 1) [Дьяченко: 340,1102 ] - содержатся и в однокоренном с ним существительном «чудеса», от формы единственного числа которого, собственно, слово «чудесный» образовано. Как видим, никаких негативных коннотаций в христианском аспекте слово «пучина» не содержит, а «пучина чудес» - это море великолепия, торжества веры.

Если с обозначенных позиций подойти к судьбе главного героя, Кирилла Филиппыча Кисельникова, в «сценах из московской жизни» под названием «Пучина», то судьба эта неожиданно наполняется библейским смыслом. Он сознательно принимает удары судьбы, даже не пытаясь им хоть как-то противостоять. Подобно библейскому Иову, Кисельников теряет все. В финале он отправляется «на площадь торговать, божиться, душу свою проклинать, мошенничать» [Островский 2: 640]. Кисельников не снимает с себя вины за все, что произошло в его жизни, не стремится себя хоть как-то обелить, а мог бы, у него были для этого все основания. Но он идет площадь со всеми своими грехами, не теряя при этом надежды все-таки обрести судьбу. Отсюда эти финальные его слова «Талан-доля, иди за мной...» как мечта о счастье и удаче. Открытый финал пьесы совпадает с незавершенностью судьбы, в которой отражаются нестроения тогдашней российской жизни.

Фамилия Кирилла Филиппыча - Кисельников - может прочитываться как нечто растекающееся, не могущее быть собранным, лишенное основания. Но если вспомнить особую любовь драматурга к пословицам, то за фамилией Кисельников как нечто ей прямо противоположное угадывается фразеологизм «молочные реки, кисельные 
берега» в значении обилия еды и достатка в целом. Однако кисель выступает в этом фразеологизме вовсе не как что-то расплывающееся, но вполне устойчивое - образует берега. Замечу, что в XIX в. в крестьянской среде варили кисель столь густой, что резали его ножом, например, кисель из гороха. В этом контексте фамилия Кисельников обретает устойчивость, смысл которой сосредоточен на осознании сущности бытия, исполненного скорби и печали, но не утратившего веры в «талан-долю».

В одной из рецензий на премьеру пьесы на сцене Малого театра 8 апреля 1866 г. было подмечено, что драматург представил Кисельникова человеком слабым, лишенным сил для борьбы с окружающим его невежеством, но уж, конечно, не глупым, а тем более - не идиотом [Азонель: 1]. Однако в 1867-1868 гг. Ф. М. Достоевский работал над романом «Идиот» с его главным героем, усматривая в нем невыработавшийся идеал. В этом плане князь Мышкин и Кирилл Кисельников фигуры равночестные.

Если по аналогии обратиться к Канону Александра Невского, то сразу бросается в глаза подчеркнутый масштаб его личности, явно не сопоставимый с Александром Свирским. Канон отличает высокая степень торжественности, общей приподнятости, что определяется совокупностью деяний Александра Невского, их общегосударственной значимостью. Вряд ли то же самое можно сказать об Островском при всем уважении к тому, что им сделано.

Тем не менее некоторые пересечения имеются. Так, на обороте печати Александра Невского всегда изображался святой Феодор Стратилат, покровитель Костромы и земли костромской, с которой была тесно связана жизнь драматурга.

И еще одно небольшое замечание. В седьмом гласе кондака Александру Невскому в икосе сказано: «латинская учения презревый». Как известно, Островский, наоборот, усиленно изучал латинский язык, переводил комедии Плавта, создал образ преподавателя классических языков в пьесе «Трудовой хлеб».

Александр Свирский, как писал Г. Федотов, «пребывал в отношениях духовной любви с Корнелием Комельским» [Федотов: 194], прямым учеником Нила Сорского, следовательно, идеи исихазма, пустынножительства были ему отнюдь не чужды. А Федотов буквально следом за процитированным фрагментом обращается к Нилу Столбенскому, из- 
бравшему подвиг уединения, столь близкий Нилу Сорскому. Двадцать семь лет Нил уединенно живет на острове Столбенском или Столобенском, не имея учеников, не построив даже часовни. «Молился перед иконой Божией Матери и кадил ей. В его келье были водружены два костыля, на которые он опирался во время сна, не зная постели» [Федотов: 194]. Монастырь на острове был поставлен, когда Нила уже не было в живых.

Этот монастырь А. Н. Островский посетит в 1856 г. во время своего путешествия. Семнадцатого мая он специально отправляется «на барже, которую буксировали лодки, с образами и певчими (3 хора) в Нилову пустынь», где проливает «несколько слез» [Островский 10: 370]. Как видим, эта поездка не была праздной. Драматург сознательно посещает монастырь, овеянный именем святого, по существу своих воззрений близкого Александру Свирскому и, по определению Г. Федотова, трагедии древнерусской святости. Трагедия заключалась в победе московского благочестия (формальной стороны веры) над «умным деланием» заволжских старцев (напряженной внутренней духовной работой). Трудно сказать, интересовался ли Островский этой проблемой, свидетельств нет. Но если видеть в его небесном покровителе Александра Свирского, то идеи древнерусской святости могли быть предметом его раздумий. Удаленное от шумной и суетной городской жизни Щелыково вполне сопоставимо с уединением Александра Свирского на берегах затерявшейся среди лесов и болот речки. Это условное сродство связано с напряженной внутренней работой, которая не покидала драматурга во время его щелыковского отдыха.

Поставленный в статье вопрос о небесном покровителе драматурга Островского, конечно, является открытым для разных суждений. Автор не претендует на полную исчерпанность обозначенной проблемы. Однако ее актуализация представляется важной и существенной для современного островсковедения. 


\section{Список литературы \\ Источники}

Азонель [Лютецкий А. О.] Из московский жизни. Театральные новости // Петербургские Ведомости. 1866. № 108. 23 апреля. С. 1.

Алексеев А. Тот, кто стоит за правым плечом. URL: http://jazz0hip.chat.ru/ang1. html (дата обращения: 07.02.2021).

Владимирова E. Н. «Духом с вами неотступно буду». Преподобный Александр Свирский: житие, подвиги, чудеса, акафист, канон. М.: Синопсисъ, 2020. 62 с.

Дьяченко Г., прот. Полный церковно-славянский словарь. M.: RUGRAM, 2017. $1168 \mathrm{c}$.

Костомаров Н. И. Петр Великий // Костомаров Н. И. Русская история в жизнеописаниях ее главнейших деятелей: в 3 книгах. Репринт изд. 1876 г. Книга III. М.: АО «Книга и Бизнес», 1992. С. 537-785.

Модзалевский Б. Л. О братьях и сестрах Островского // Островский. Новые материалы. Письма. Труды и дни. Статьи / под ред. М. Д. Беляева. Л.: ГИЗ, 1924. C. 244-258.

Ожегов С. И. Толковый словарь русского языка / под ред. Л. И. Скворцова. М.: Мир и образование, 2020. 1375 с.

Островский А. Н. Полн. собр. соч.: в 12 т. / под общ. ред. Г. И. Владыкина, И. В. Ильинского, В. Я. Лакшина и др. М.: Искусство, 1974-1980.

\section{Исследования}

Кайдаш-Лакшина С. Н. Именины Островского и небесный покровитель Александр Свирский // Щелыковские чтения 2018. А. Н. Островский и его наследие: судьба во времени. Сборник научных статей и материалов / науч. ред. и сост. И. А. Едошина. Кострома: Авантитул, 2019. С. 26-31.

Соловьев С. М. Публичные чтения о Петре Великом // Соловьев С. М. Чтения и рассказы по истории России / сост. и вступ. ст. С. С. Дмитриева. М.: Эксмо, 2015. C. 414-583.

Федотов Г. П. Святые Древней Руси / предисл. Д. С. Лихачева и А. В. Меня; коммент. С. С. Бычкова. М.: Московский рабочий, 1990. 269 с. 


\section{References}

Kaidash-Lakshina, S. N. "Imeniny Ostrovskogo i nebesnyi pokrovitel' Aleksandr Svirskii" ["Ostrovsky's Name Day and Patron Saint Alexander Svirsky"]. Shchelykovskie chteniia 2018. A. N. Ostrovskii i ego nasledie: sud'ba vo vremeni. Sbornik nauchnykh statei i materialov [Shchelykovo Proceedings 2018. A. N. Ostrovsky and his Legacy: Fate in Time. Collection of Scientific Articles and Materials], sci. ed. and comp. by I. A. Yedoshina. Kostroma, Avantitul Publ., 2019, pp. 26-31. (In Russ.)

Solov'ev, S. M. "Publichnye chteniia o Petre Velikom" ["Public Readings about Peter the Great"]. Solov'ev, S. M. Chteniia i rasskazy po istorii Rossii [Readings and Stories on the History of Russia], comp. and introd. by S. S. Dmitriev. Moscow, Eksmo Publ., 2015, pp. 414-583. (In Russ.)

Fedotov, G. P. Sviatye Drevnei Rusi [Saints of Ancient Russia], introd. by D. S. Likhachev and A. V. Men', comm. by S. S. Bychkov. Moscow, Moskovskii rabochii Publ., 1990. 269 p. (In Russ.) 


\section{Храмовая поэтика метаромана И. А. Гончарова}

Аннотация: В статье обосновывается представление о храмовой тетралогии Гончарова («Обыкновенная история», «Обломов», «Обрыв» и «Фрегат Паллада»), критерием структурно-содержательного единства которой является храмово-литургическая основа, присущая всем четырем произведениям. Путь героев в них протекает внутри «храмовой модели» и оценивается автором в соответствии с ее аксиологией. Под храмовой поэтикой нами понимается воплощение в тексте феноменов, имеющих отношение ко всему православному догмато-литургическому онтосу Церкви, а не только к образу храма. Сюжет Александра Адуева рассматривается как «пошлое путешествие», лже-хождение в Петербург - двойник Европы. Во «Фрегате Паллада» изучается «особый» повествовательный статус героя, позволяющий совместить «внутри» и «вне» сюжетную точки зрения. Обращается внимание на изменение направления пути героя, стремящегося не вперед, к «прогрессу», а назад, к «праотечеству». В отношении романа «Обломов» обосновывается точка зрения о «динамике» «внутренней жизни» героя, совершающего «внутреннее путешествие» на Восток. «Обрыв» определяется в статье как роман, действие которого сосредоточивается на "русских берегах". Борис Райский проходит путь от художника-дилетанта к художнику-почвеннику. Подчеркивается значимость пространства провинциальной России, противопоставившей «обрывам» русской истории верность своему пути и идеалам.

Ключевые слова: И. А. Гончаров, храмовая поэтика, тетралогия, повествование, образ России, храмово-литургическая символика.

Информация об авторе: Галина Владимировна Мосалева, доктор филологических наук, профессор, Удмуртский государственный университет, ул. Университетская 1, корп. 2, 426034 г. Ижевск, Россия ORCID ID: https:/orcid.org/0000-00015342-7305

E-mail: mosalevagv@yandex.ru

Дата поступления статьи в редакиию: 29.01.2021

Дата одобрения статьи рецензентами: 31.05 .2021

Дата публикации статьи: 30.09.2021

Для изитирования: Мосалева Г. В. Храмовая поэтика метаромана И. А. Гончарова // Два века русской классики. 2021. Т. 3, № 3. С. 84-103. https://doi. org/10.22455/2686-7494-2021-3-3-84-103 


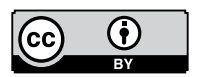

This is an open access article distributed under the Creative Commons Attribution

4.0 International (CC BY 4.0)
Dva veka russkoi klassiki,

vol. 3, no. 3, 2021, pp. 84-103. ISSN 2686-7494

Two centuries of the Russian classics,

vol. 3, no. 3, 2021, pp. 84-103. ISSN 2686-7494

Research Article

(c) 2021. Galina V. Mosaleva

Udmurt State University

Izhevsk, Russia

\title{
Temple-related Poetics of Goncharov's Meta-Novel
}

\begin{abstract}
The article justifies the representation of Goncharov's temple-related tetralogy, which includes "A Common Story", "Oblomov", "The Precipice" and "Frigate 'Pallada". Temple-related and liturgic principles of the tetralogy are defined as the measure of its structural and conceptual integrity. Paths of heroes in the novels under discussion lie within the "temple-related model" and should be evaluated in line with the axiology of this model. The storyline associated with Alexander Aduev is considered as "vulgar travel", "pseudo-pilgrimage" to Saint-Petersburg, the city which became "Russian Europe". The novel "Frigate 'Pallada"' focuses on the peculiar "narrative" status of the hero, and this focus allows to combine "inner" and "extra" storylines. The novel highlights certain changes in paths of hero who moves backward to "the great Motherland" instead of moving forward to "the progress". Concerning the novel "Oblomov", one can notice that this writing justifies the point associated with "dynamics" of the hero's "interior life" who travels inside and reorients himself from the West to the East. The article considers "The Precipice" ("Obryv") as Goncharov's most "pedalogical" novel with its focus on "Russian brinks". Boris Raisky ran the gamut from an amateur artist to the artist - "man of the soil". The novel emphasizes the significance of territories of "provincial Russia" struggling to "heal misguided paths" and to eliminate "precipices" of Russian History.
\end{abstract}

Keywords: Ivan Goncharov, temple poetics, tetralogy, narrative, image of Russia, church and liturgical symbols.

Information about the author: Galina V. Mosaleva, DSc in Philology, Professor, Udmurt State University, Universitetskaya st., 426034, 1/2, Izhevsk, Russia. ORCID ID: https://orcid.org/0000-0001-5342-7305

E-mail: mosalevagv@yandex.ru

Received: January 29, 2021

Approved after reviewing: May 31, 2021

Published: September 30, 2021

For citation: Mosaleva, G. V. "Temple-related Poetics of Goncharov's Meta-Novel." Dva veka russkoi klassiki, vol. 3, no. 3, 2021, pp. 84-103. (In Russ.) https://doi.org/10.22455/26867494-2021-3-3-84-103 
В романное единство И. А. Гончарова обычно включают три его знаменитых романа: «Обыкновенную историю» (1848), «Обломов» (1859), «Обрыв» (1869). В данной статье мы попытаемся обосновать представление о едином метаромане Гончарова, в который, помимо названных текстов, входит и «Фрегат Паллада» (1858). Термин метароман в отношении знаменитого «Пятикнижия» Достоевского удачно применил Н. Нейчев [Нейчев: 179], демонстрируя в нем весь комплекс проявления «храмовой поэтики», связанной с православием. Может быть, более удачным для обозначения подобного сверхструктурного единства в случае с Гончаровым стал бы термин метаповествование, позволяющий исключить спорный момент в определении жанра «Фрегата Паллады».

Подобное сверхструктурное единство, формируемое «храмовой основой», мы увидели в четырех повествованиях Гончарова. Отдельные храмовые мотивы и образы, некоторые литургические аспекты и особенности воплощения храмово-литургической модели на примере этих произведений мы уже отчасти рассматривали в своих статьях о Гончарове [Мосалева 2017a, 20176, 2017в, 2018a, 20186]. Под храмовой поэтикой понимается воплощение в тексте феноменов, имеющих отношение ко всему православному «догмато-литургическому онтосу Церкви» [Нейчев: 29] , а не только к образу храма. На наш взгляд, эти термины наиболее полно позволяют объяснить специфику православной образности в художественном тексте, выражаемой такими определениями, как «христианский текст», «евангельский текст», духовная проблематика и др. Храм и православная литургия - неразделимые понятия, составляющие «храмово-литургическое единство» [Нейчев: 47]. И в Священном Писании, и в святоотеческом наследии храмом именуется не только конкретное церковное архитектурное строение, но и сотворенная Богом природа и ее венец, человек, приглашающий в свое сердце Христа. Храмовая литургичность включает в себя цер- 
ковные таинства, связанные с православной идеей соборности, а также такие субстанциальные явления православной духовности, как икона, церковная служба, молитва, - словом, все, что относится к миру Православия, сохраняющего подлинный лик Христа. Все эти глубинные, мистико-религиозные смыслы в особенной мере отражает православная христианская словесность.

В данной работе мы попытаемся показать, что именно православная «храмовая основа» позволяет говорить о четырех повествованиях Гончарова как своеобразной храмовой тетралогии, свидетельствующей о христианском мироотношении писателя, последовательно в них проявляющемся. Храмово-литургическое измерение в тетралогии Гончарова связано с авторским восприятием мира «своего» и «вселенского», «земного» и «небесного», «человеческого» и «божественного», «умного» и «сердечного».

$\mathrm{B}$ «Обыкновенной истории» Гончаров развенчивает романтического героя - «обыкновенного юношу» Александра Адуева, «каких везде - легион» [Гончаров 1977. 1: 103], намеренного стать «необыкновенной личностью».

Инфернальная природа образа героя изначально подчеркивается фамилией Адуев [Мельник 2009: 146], обрастая по мере развития сюжета «змеиными» мотивами. Образ дороги-змеи из Грачей в Петербург словно проникает в героя, и в истории с Наденькой он уже сам, «как змей», выскальзывает в двери» [Гончаров 1977. 1: 122]. В третьей любовной истории, с Лизой, Адуев-младший предстает змеем-обольстителем. Помимо любовной линии, «змеиный мотив» у Гончарова связан с темой творчества героя-романтика. Разочаровавшись в писательском призвании, Адуев сжигает свои «литературные тетради», превращающиеся в «кучу черного пепла, по которому местами пробегали огненные змейки» [Гончаров 1977. 1: 208].

«Чужое слово» в «Обыкновенной истории» образует своеобразную «литературную вселенную», относящуюся к Античности, к западноевропейской и отечественной литературе. Но нельзя сказать, что «судьбу своего героя» Гончаров «истолковывает с помощью языческого, а не христианского мифа», что герой обречен на гибель и «происходящее с Александром было определено Роком» [Долженков: 10-12]. Сравнение героев с античными персонажами у Гончарова предстает, как правило, в комическом аспекте, как прием, но не как проявление авторского 
мировосприятия. Так, «начальник отделения» видится Адуеву Юпитером-громовержцем, едва он «открывает рот - и бежит Меркурий с медной бляхой на груди» [Гончаров 1977. 1: 88]. Восприятие судьбы как рока присуще «вечной тетушке» Марии Горбатовой («...рок разлучил нас» [Гончаров 1977. 1: 58]), воспринимаемой Петром Адуевым как объект осмеяния и сохраняющим ее письмо для «коллекции».

Во всех четырех повествованиях Гончарова большинство сюжетных ситуаций имеет христианскую мотивировку, и все они пронизаны авторским христианским мироотношением. «Обыкновенная история» не исключение. Гончаров называет ее «первой галереей», служащей «преддверием к следующим двум галереям или периодам русской жизни, уже тесно связанным между собою, то есть к «Обломову» и «Обрыву», или к «Сну» и к Пробуждению» [Гончаров 1977. 8: 114].

«Обыкновенная история» Гончарова - это рассказ о не возвращающемся к Отцу «блудном сыне», мотив которого в романе существенно трансформируется: во-первых, вместо евангельского отиа, смиренно отпускающего сына, выступает мать, пытающаяся его удержать. Во-вторых, молчанию Отца противопоставляется наставление матери. Мать понимает, что сын не будет посещать «храм Божий» [Гончаров 1977. 1: 43], оправдывая его и обещая вымолить для сына «и здоровье, и чинов, и крестов, и небесных и земных благ» [Гончаров 1977. 1: 4]. Под «крестами» Анна Павловна, конечно же, имеет в виду земные знаки отличия, а не спасительный Крест Христов. Ее понимание христианства весьма приземленное и прагматичное. Тем не менее, перед нами пусть и трансформированная, но все-таки притча о блудном сыне, где Гончаров останавливает внимание читателя на «уходе» сына из родительского гнезда и катастрофизме духовных последствий этого выбора.

Мечтая о писательской славе, Александр приезжает в Петербург восторженным романтиком, забывая все материнские наставления о Боге. Встреча с дядюшкой Петром Адуевым уязвляет самолюбие героя, а влияние культурно-мифологического пространства Петербурга как «заколдованного места» перерождает Адуева-младшего до неузнаваемости. Вглядывание в Медного всадника превращает Адуева в своеобразного скульптурного двойника каменного истукана: его сердце каменеет и ум цепенеет.

Адуев начинает испытывать стыд за привязанность к Грачам, «преважно» прохаживается «по Невскому проспекту, считая себя гражда- 
нином нового мира» [Гончаров 1977. 1: 68]. Он испытывает радость от своей принадлежности к другому, инфернальному миру. Знакомство с Костяковым, двойником гоголевского Ноздрева, словно низводит Адуева в глубины преисподней, поскольку Костякова можно сравнить с Проводником в «царстве мертвых»: он любил присутствовать на панихидах, глядеть на мертвеца и «провожать его на кладбище» [Гончаров 1977. 1: 257].

Александр Адуев возвращается в Грачи после семи лет жизни в Петербурге. Пророческий сон матери о сыне, взявшемся «из омута... от домовых» [Гончаров 1977. 1: 295] накануне его возвращения домой, ставит его в положение «самоубийцы». Символично, что при встрече мать не узнает своего сына: «Где твои волоски? как шелк были! <...> щеки - кровь с молоком; весь ты был как наливное яблочко!» [Гончаров 1977. 1: 297].

Попытка матери вернуть сына в храм терпит неудачу: он дважды просыпает обедню и нехотя соглашается пойти ко всенощной. В отличие от матери, Александр остается у дверей храма в позе скучающего наблюдателя. Адуев отказывается от подлинных отношений с Богом, обнаруживая свою несостоятельность и заурядность. Лишь «детские «воспоминания» о религиозной атмосфере дома, пронизанной искренней и безыскусной верой и расширяющей духовный горизонт юной души еще удерживают его от окончательного падения. Александр вспоминает, как мать учила его молитвам, как, «указывая ему на звезды», говорила, «что это очи Божиих ангелов... [Гончаров 1977. 1: 310]. Герой сожалеет об утрате «младенческих верований»: «Боже! когда теплота веры не греет сердца, разве можно быть счастливым!» [Гончаров 1977. 1: 310]. Однако герой все-таки поддается духу времени, изо всех сил стараясь идти в ногу с веком. И чем больше он соответствует модным веяниям, тем больше дурнеет и стареет.

«Обыкновенная история» - это рассказ о том, как быстро герой-романтик и мечтатель о «славе», «колоссальных страстях», особом «гражданстве мира», отрывается от исторической России вследствие своего осознанного отказа от храма и изменяет своим «младенческим верованиям». Отказ от храма сопряжен с отказом от Слова, не случайно пути художника Адуев предпочитает карьеру чиновника.

Несмотря на свой широкий культурный и интеллектуальный кругозор, Адуев-младший лишен духовного зрения. Поиск «земного рая», 
погоня за модой века оказывается для героя духовной катастрофой: дорога из дома приводит лишь в «омут» чужой жизни, к измене «своему» миру, к утрате всего лучшего, что было у Адуева, «к карьере и фортуне». В финале романа герой абсолютно совпадает со своей говорящей фамилией, с «теми», «каких везде - легион» [Гончаров 1977. 8: 103]. С развитием сюжета принадлежность к бесовскому пространству проявляется в нем все сильнее: «Какой-то бесенок все шевелился в нем, все шептал ему, что это мелко для него» [Гончаров 1977. 1: 258].

Все его последующие чувства, стремления и движения души оказываются исчисленными. В разговоре с дядей Александр даже не называет имени своей «богатой невесты», но сообщает, что она «дочь Александра Степаныча», дающего за ней «пятьсот душ и триста тысяч денег» [Гончаров 1977. 1: 336].

Во «Фрегате Паллада» проблема поиска Своего Пути встает с новой силой, поскольку путь бездумного следования героя за своим веком и модой в «Обыкновенной истории» оказывается ложным. О «загадочности» жанровой природы «Фрегата Паллада», разных точках зрения по поводу определения жанра этого текста мы писали в одной из наших работ [Мосалева 2018: 328-334]. Поскольку мы рассматриваем «Фрегат Паллада» входящим в храмовую тетралогию Гончарова, сошлемся на работу В. Недзвецкого [Недзвецкий: 124-137], в которой представлена концепция о «Фрегате Паллада» как «географическом романе». В нашем понимании это, скорее, предроман с яркой импровизационной повествовательной структурой и отмечаемой многими гончарововедами «романизацией» описываемых событий и впечатлений. Однако свойства, присущие роману-путешествию и роману-миросозерцанию, в этом не поддающемся однозначному жанровому определению тексте, на наш взгляд, явно проступают, поэтому идея В. Недзвецкого о романической природе «Фрегата Паллада» оказывается весьма интересной.

«Фрегату "Палладе" п писуща рождественская структура: путешествие начинается накануне Рождества Христова и завершается им. Упоминаются в художественном мире и другие православные праздники. В главе «От Манилы до берегов Сибири» сообщается о Страстной неделе и Пасхе: «Сегодня 11-е апреля - Пасха; была служба как следует: собрались к обедне со всех трех судов; потом разгавливались. Выписали яиц из Нагасаки, выкрасили и христосовались» [Гончаров 1986: 469]. 
Пускаясь в путешествие ради избавления «от скуки», автор-путешественник вместе с тем испытывает страх, что может не возвратиться домой и больше не увидеть «главы и кресты» [Гончаров 1986: 14]. Они являются «храмовым символом» Отечества. При возвращении в Россию в «сибирских главах» в кругозор путешественника-повествователя непременно включаются «главы и кресты» православных храмов [Гончаров 1977: 491] как сакральные символы Отечества. «Русский корабль» олицетворяет собой «Россию в миниатюре». Он отправлялся на отыскание идеального жизнеустройства «как для себя, так и для других народов», поэтому его можно назвать центральным героем [Недзвецкий: 134]. Образ корабля «восходит к Священному Писанию. Ноев ковчег - первый образ в Ветхом Завете, прообразующий церковь Христову, спасающую всех, кто вошел в нее» [Мосалева 2018: 329]. «Военный парусник» явился у Гончарова воплощением Дома-Почвы, России-Обломовки. Ощущение устойчивости помогало путешественнику справиться с «океанами» как воплощением «чужого»: «Увижу новое, чужое и сейчас в уме прикину на свой аршин. Я ведь уж сказал вам, что искомый результат путешествия - это параллель между чужим и своим. Мы так глубоко вросли корнями у себя дома, что, куда и как надолго бы я ни заехал, я всюду унесу почву родной Обломовки на ногах, и никакие океаны не смоют ее!» [Гончаров 1986: 54].

В отличие от карамзинского путешественника и «рядовых искателей приключений в дальних странах», гончаровский герой пассивен [Краснощекова: 165]. Ему дороги «воспоминания о покинутой родине». Он прославляет Творца за дивно устроенный мир и его божественную красоту. Гончаровского путешественника привлекают «не Париж, не Лондон и не Италия, а Бразилия, Индия... светлые чертоги Божьего мира» [Гончаров 1986: 9]. Он стремится не в настоящее и будущее, а к истокам цивилизации, где «человек, как праотец наш, рвет несеянный плод, где рыщет лев, пресмыкается змей, где царствует вечное лето» [Гончаров 1986: 9], чтобы «воскресить мечты», «расшевелить воспоминания», «обновиться».

Возвращаясь домой через Сибирь «долгим» путем, вследствие поломки парусника, Гончаров увидел образец идеального жизнеустройства там, где не ожидал: «среди океана снегов» [Гончаров 1986: 492]. Возвращение на родину отражено в трех главах: с VII по IX. На этом пути то и дело возникают купола православных церквей: «зеленый ку- 
пол церкви с золотым крестом» [Гончаров 1986: 491] во время путешествия по Охотскому морю - купол Спаса Преображения в Амгинской слободе и Витиме. И, несмотря на то что сибирский край - «печальный, пустынный и скудный», где вместе живут представители многочисленных северных народов, - «все они христиане, у всех медные кресты, все молятся <...> и всюду здесь водружен крест благодаря стараниям Иннокентия и его предшественников» [Гончаров 1986: 506]. Плоды трудов преосвященного Иннокентия (мирское имя - Иван Евсеевич Попов-Вениаминов), епископа Камчатского и Алеутского, а позже митрополита Московского и Коломенского, встречаются на всем протяжении пути по Сибири. Преосвященный своими трудами и делами словно «приветствует» каждого «проезжего». Еще один герой, «маленький титан», встретившийся путешественнику на реке Мае, отставной матрос Сорокин, пожертвовавший церкви четыре десятины возделанной земли и переселяющийся «опять в другое место, где, может быть, сделает то же самое» [Гончаров 1986: 530].

В «сибирских главах» Гончаров изображает многочисленных подвижников-просветителей, настоящих апостолов веры, возвращающих «Творцу плод от брошенного Им зерна» [Гончаров 1986: 525]. И важно, что «титанов» не один и не два, а «целый легион», и они действуют не разрозненно, а все вместе. Разные сословия: «дворяне, духовные, купцы, поселяне» трудятся в своеобразной «лаборатории» христианского Просвещения, преобразуя «сибирскую пустыню» в «жилые места», «вызывают к жизни спящие силы» [Гончаров 1986: 525]. В «сибирских главах» гончаровский путешественник проявляет себя не как сторонний наблюдатель, а как «живой, заезжий свидетель <..> химически-исторического процесса» [Гончаров 1986: 525] христианского Преображения.

В этой преобразовательной деятельности участвуют не только такие титанические личности священников-просветителей, как Хитров и Запольский, в течение десяти лет не знающие покоя, с ревностью и смирением служащие новокрещеным племенам, но и многочисленные обитатели сибирской земли. Таков станционный смотритель, встречающий «заезжего свидетеля» в мундире и со шпагой в знак уважения к гостю, таковы многочисленные семейства, дающие ради Христа кров и пищу проезжающим, окружая их настоящей любовью и заботой. Сам тон повествования в «сибирских главах» становится веселее и бодрее, 
путешественникам то и дело встречались «ласковые лица» [Гончаров 1986: 522]. Судьбы у многих из обладателей ласковых лиц совсем не радостные, но их терпение, вера и мужество превращают их в ветхозаветных персонажей, как, например, ямщика Дормидона: ““Это страдания Иова!" - думал я, глядя на него с почтением. Дормидон претерпел все людские скорби - и не унывает... А мы то: палец обрежем, ступим неосторожно...» [Гончаров 1986: 522]. «Сибирская цивилизация», как ее изображает во «Фрегате Паллада» Гончаров, далека от идиллического Рая, источниками ее Преображения явились Божье Слово и христианская деятельность русских миссионеров, наполненная трудами, жертвами, верой, неисчерпаемым оптимизмом и энергией. Их вдохновляющий пример явился одним из важных итогов путешествия Гончарова. Что же открылось Гончарову в центральной России?

Главный герой романа «Обломов» предстает как путешественник-созерцатель, а его «любовь» к «дивану» метафорически символизирует отказ от внешней суеты, динамику внутренней жизни, независимость и достоинство, верность своему «дому» [Анненский]. Национальную доминанту образа Обломова отмечали уже самые первые критики романа, наиболее ярко А. В. Дружинин: «Он дорог нам по истине, какою проникнуто все его создание, по тысяче корней, которыми поэт-художник связал его с нашей родной почвою» [Дружинин].

«Лежанье» Обломова активно и мотивировано: герой отказывается от европейского «фрака» в пользу «персидского халата», символизирующего культурно-цивилизационный поворот России от Запада к Востоку, он «без малейшего намека на Европу», «поместителен», «мягок» и «гибок» [Гончаров 1977. 4: 8]. Обломовский халат - вещь вневременная, Обломов и не гонится за модой наподобие Александра Адуева. Обломов не безразличен к происходящему в обществе и культуре, о чем свидетельствует его разговор с литератором Пенкиным, предлагающим «извергнуть» «падшего человека» из гражданской среды: «Извергнуть! А как вы извергнете его из круга человечества, из лона природы, из милосердия Божия? - почти крикнул он с пылающими глазами» [Гончаров 1977. 4: 27].

Об Обломове больше судят по внешним признакам, о его внутреннем мире никто и не догадывается, даже Штольц. Ольге скучен патриархальный настрой Обломова, его стремление к неизменному миру, повторяемости событий, впечатлений, праздников: «А с тобой мы 
стали бы жить изо дня в день, ждать Рождества, потом масленицы...» [Гончаров 1977. 4: 374].

Агафья Матвеевна - полная противоположность Ольги: «Из главных героев только Агафья Матвеевна важнейшие акты своей жизни переживает в церкви», «только эта героиня любит истинно христианской любовью в романе» [Мельник 2009]. Жизнь Обломова с Агафьей Матвеевной наполняется радостью, покоем, общими ценностями: «На масленице и на Святой вся семья и сам Илья Ильич ездили на гулянье кататься...» [Гончаров 1977. 4: 481]. Агафья Матвеевна прибегает в храм Рождества к ранней обедне, она подает записки о здравии Ильи и молится. Она верит искренне и просто, ей не важно, как она выглядит со стороны.

В конце романа Штольц объясняет Ольге причину ее любви к Обломову, связанной с его «честным, верным сердцем», противостоящим «океану дряни и зла» [Гончаров 1977. 4: 473]. В контексте неожиданно появившегося образа океана сердце Обломова уподобляется храму-кораблю, сравнивается с золотом, перлом: «Ни одной фальшивой ноты не издало его сердце, не пристало к нему грязи. Не обольстит его никакая нарядная ложь, и ничто не совлечет на фальшивый путь» [Гончаров 1977. 4: 473].

После слова Штольца о друге Ольга «задумывается, и в ее воспоминании «воскресает» «кроткое, задумчивое лицо Обломова» [Гончаров 1977. 4: 474]. Слово «воскресает» вводит образ Обломова в христианский контекст.

По наблюдению В. И. Мельника, «в окончательной редакции «Обломова» все религиозные акценты сняты или, вернее сказать, скрыты. Если бы все евангельские дары Обломова были освящены в романе именем Христовым, то перед нами был бы совсем иной образ, очевидно, напоминающий князя Мышкина из романа Достоевского «Идиот» [Мельник]. Однако прямого уподобления Обломова Мышкину в «Подготовительных материалах» к роману «Идиот» мы не нашли. Что же касается рукописных редакций и Подготовительных материалов к «Преступлению и наказанию», то образ Христа у Достоевского, в частности, возникает и в связи с образом Обломова. В Подготовительных материалах к третьей редакции читаем: «Глава "Христос" (как “Сон Обломова”) кончается пожаром» [Достоевский 7: 166].

Чаще же в критике приводится отрицательное высказывание Достоевского об Обломове из «Записной книжки» писателя 1864-1865 гг.: 
«...Обломов. Русский человек много и часто грешит против любви; но и первый страдалец за это от себя. Он палач себе за это. Это самое характеристичное свойство русского человека. Обломову же было бы только мягко. Это только лентяй, да еще вдобавок эгоист. Это даже и не русский человек. Это продукт петербургский. Он также и барич, но и барич-то уже не русский, а петербургский...» [Достоевский 20: 204].

Тем не менее в 9 томе академического издания сочинений Достоевского, содержащем материалы и варианты романа «Идиот», в примечаниях публикуется разговор Достоевского с наборщиком М. А. Александровым, которому Достоевский подарил новое издание романа: «Впоследствии, когда "Идиот" был уже давно мною прочитан, однажды в разговоре коснулись И. А. Гончарова и я с большою похвалою отозвался об его “Обломове”, Федор Михайлович соглашался, что “Обломов" хорош, но заметил мне:

- А мой идиот ведь тоже Обломов.

- Как это, Федор Михайлович? - спросил было я, но тотчас спохватился. - Ах да! Ведь в обоих романах герои - идиоты.

- Ну да! Только мой герой лучше гончаровского... Гончаровский идиот - мелкий, в нем много мещанства, а мой идиот - благороден, возвышен» [Достоевский 9: 419]. Достоевский «постоянно возвращался» к этому образу, «задумывая роман о писателе (февраль 1870 г.), он стремился включить в него “поэтическое представление вроде Сна Обломова, о Христе”» [Отрадин: 147].

Разговор Достоевского с наборщиком самым естественным образом поднимает новую и интересную проблему понимания «христианской ипостаси» образа Обломова в сопоставлении его с князем Мышкиным [Бланк]. Попытка ее решения представлена К. Бланк, обратившей внимание на то, что оба героя «идиоты», «младшие братья» из русских сказок, «иванушки-дурачки»; на связь героев со святоотеческой традицией, с исихазмом, на их неподверженность тщеславию, суетности, сребролюбию [Бланк: 473-479]. Лень является комической чертой Обломова, но она, по мысли К. Бланк, «не оттеняет его христианские добродетели», он осмеян и не знает себе цены, как и Мышкин, что позволяет считать Обломова одним из его прототипов [Бланк: 480-481].

Гончаров сравнивает своего героя с языческим мудрецом Платоном, воспитанным «не как гладиатор для арены, а как мирный зритель боя» [Гончаров 1977. 4: 480]; а сам мир героя — с «Илиадой русской 
жизни», заснувшей колдовским сном. Видя «меру душевной красоты русского человека из образованного класса» и «начала народные, начала христианские» в душе Обломова, являющейся залогом будущего развития, Ю. Н. Говоруха-Отрок говорит о ее неразбуженности, томлении «потребностью деятельной любви» [Говоруха-Отрок: 533]. На наш взгляд, именно сердце-храм Ильи Ильича, сохраняющее в себе образ Христа, является почвой Обломовки-России, которую не смогут смыть «никакие океаны».

«Обрыв» можно назвать романом-воспоминанием, его план возникает у Гончарова в связи с его приездом на родину в 1849 г. после четырнадцатилетнего отсутствия. Неожиданным образом в «Обрыве» отражается образ блаженного Андреюшки, Андрея Ильича Огородникова - симбирского святого, о котором, конечно, знал Гончаров. Не случайно Ю. Лощиц первые страницы биографии о Гончарове посвящает именно этому юродивому [Лощиц: 5]. Андреюшка общался символически: если человеку предстояла смерть, подавал щепку или горсть земли, а если ожидала прибыль, то денежку. О духовной связи семьи Гончаровых с этим удивительным святым подробно и полно написал В. Мельник: «Особенно часто простаивал он в снежных сугробах ночи перед алтарем Вознесенского собора, который находился на большой Саратовской улице, то есть прямо около дома Гончаровых. Там его не раз заставал стоящим в снегу священник В. Я. Архангельский, который и был духовником блаженного» [Мельник 2012: 49].

Но мы не согласимся с утверждением, что Гончаров «нигде, в том числе и в романе “Обрыв” не говорит о “живой легенде Симбирска”» [Мельник 2012: 50]. «Местом», где возникает образ Андреюшки Симбирского, является знаменитый сон Татьяны Марковны о «щепке на снегу» - вещи и символической, и иконической: блаженный Андреюшка Симбирский изображается на иконах со щепками в руках (символ, напоминающий о бренности земной жизни, необходимости покаяния). Сон снится Татьяне Марковне до «падения» Веры, означающего ее духовное «отщепление» от духовных основ русской жизни.

Возможны иные трактовки этого эпизода [Пырков: 51], однако нам представляется более убедительной его связь с образом блаженного Андреюшки Симбирского.

«Обрыв» - «волжский» роман, где Волга - сакральный символ России. Действия второй и пятой частей романа происходят на волж- 
ских берегах. Татьяна Марковна, Вера, Марфенька, Викентьев, Тушин, Райский оказываются достойными великой реки.

Марка Волохова Волга «наказывает»: его рыбачья лодка попадает «в тину». Вместо двери Марк выпрыгивает из окна, и Райский думает о нем: «Не любит прямой дороги!» [Гончаров 1977. 6: 284].

Попытка Веры вывести лже-апостола Марка из оврага в храм на горе заканчивается драматически: она едва не погибает. Имя героини «говорящее», Гончаров рассматривал его как один из вариантов названия романа [Краснощекова: 407]. Однако личной веры и сил героини, основанных лишь на уверенности в себе, оказывается недостаточно для подобного подвига. Не случайно в сюжете Веры в связи с ее падением появляется образ тонущей ладьи. Благородный порыв вне Христа обречен, поскольку он произрастает из гордыни и тщеславия. Сюжет «Обрыва» намного шире, чем драматическая история героини как несостоявшейся спасительницы героя-антагониста, отвергшего мир ее ценностей. В своем последнем романе Гончаров показывает православную веру русского человека перед лицом соблазнов и искушений, при встрече с героями-бесами. Гончаров своим «Обрывом» вступал в сферу, свойственную романам Достоевского. Но если у Достоевского «беснование» мира приобретает вселенский апокалиптический масштаб, то у Гончарова оно локализовано в национальных границах, спасающих Россию от катастрофизма.

Соотношение главных образов «Обрыва» с евангельскими общеизвестно. Марфенька - самый яркий пример прямого соотношения с евангельским прототипом. «Божьи младенцы» Марфенька и Викентьев выбирают путь послушания Бабушке. Он простой, радостный и счастливый.

Вера же соответствует не прототипу Марии из Вафании, бывшей «при ногу Иисусову, слышаше слово Его» [Лк. 10: 38-42], а прототипу другой евангельской Марии - «блудницы у ног Христа». Путь Веры оказывается самым извилистым, она и называет себя не мудрой девой, хранящей «елей» для брака с Христом, а «мудреной». Не случайно ее душа сравнивается с «темным, запущенным храмом» [Гончаров 1977. 6: 339]. Однако в душе Веры сохраняется самое важное свойство, способное восстановить прежде утраченное общение с Богом - покаяние. Оно преображает ее душу, восстанавливает единение с Богом и ближними. К ней возвращаются теплота, легкость, тишина, мир, свет, надежда. 
В деревянной часовне перед образом Спасителя в разное время оказываются Вера, Бабушка и Райский. Образ Бабушки является своеобразной персонификацией Русской и Священной истории. Бабушка представляется Райскому в образе древней еврейки, иерусалимской госпожи, новгородской Марфы, в образах русских цариц, боярынь и княгинь, сохраняющих в бурных водоворотах истории силу духа.

Русская Глубинка в «Обрыве» оказывается в эпицентре борьбы добра и зла, являясь пространством евангельского события. Петербург Малиновка - Рим - топосы пути Райского, но из них пространством подлинной встречи с Истиной оказывается Малиновка-Россия. В отличие от Александра Адуева, Райский не изменяет своему предназначению художника. По мысли Кирилова, искусство сродни монашескому подвигу. Оно тоже требует от художника, как и от подвижника-аскета трудов, воздержания, жертвенности и верности своему предназначению. Духовный перелом в душе Райского происходит уже в финале романа, когда его отвлеченный от жизни артистизм сменяется почвенничеством. В музеях Рима за всеми картинными образами он видит другую, «исполинскую фигуру», влекущую его к себе «великую “Бабушку” - Россию» [Гончаров 1977. 6: 422] - образ не живописный, а иконический.

Как видим, во всех четырех повествованиях Гончарова в той или иной степени отчетливо проявилась присущая русской словесности храмово-литургическая основа, объединяющая все четыре вершинных текста в одно поэтическое целое. Отказ от храма, от своего родового наследия приводит Адуева-младшего к духовной смерти, к измене поприщу художника, к опошлению и измельчанию, к превращению романтика-идеалиста в героя из преисподней, к типу мелкого беса. Поиск новых путей для развития личности и цивилизации заставляет Гончарова отправиться в кругосветное путешествие на «Фрегате Паллада» через моря и океаны и иначе, в свете деятельной любви, взглянуть на мир родной почвы, открыть преображенную Светом Христовой Личности русскую Сибирь, а затем и великую матушку-Россию. Путешествие вызвало у Гончарова интерес к внутреннему устройству России, ее преданиям, архетипам, идеалам. Кроткое и чистое сердце Обломова является у Гончарова олицетворенным храмом, залогом будущего развития Обломовки-России. Неделание Обломова выступает в качестве своеобразного символа - евангель- 
ского уклонения героя от зла, от внешней тщеславной суетливости. Однако неподвижный мир русской идиллии сталкивается в «Обрыве» с современными вызовами, с угрожающими исторической России социальными и нравственными потрясениями. В «Обрыве» в полной мере обнаруживает себя исторический оптимизм Гончарова, убежденного, что после социальных катастроф и потрясений Россия рано или поздно обратится к покаянию и вернется в храм, к своему отеческому наследию. В романе авторская мысль выражается ясно и отчетливо: каким бы испытаниям ни подвергалась православная вера русского человека, бояться их не стоит, но и питать иллюзии в отношении изменения природы зла не следует. Искреннее обращение ко Христу способно преобразить темный и «запущенный» храм души, устраняя тем самым и метафизические «обрывы». 


\section{Список литературы \\ Источники}

Анненский И. Гончаров и его Обломов. URL: http://az.lib.ru/a/annenskij_i_f/ text_0420.shtml (дата обращения: 24.05.2020).

Говоруха-Отрок Ю. Н. И. А. Гончаров // Говоруха-Отрок Ю. Н. Во что веровали русские писатели. Литературная критика и религиозно-философская публицистика. СПб.: Росток, 2012. Т. 1. С. 531-534.

Гончаров И. А. Собр. соч.: в 8 т. М: Худож. лит., 1977.

Гончаров И. А. «Фрегат “Паллада"». Очерки путешествия в двух томах. Л.: Наука, 1986.879 с.

Достоевский Ф. М. Полн. собр. соч.: в 30 т. Л.: Наука, 1972-1990.

Дружинин А. В. «Обломов». Роман И. А. Гончарова. URL: http://az.lib.ru/d/ druzhinin_a_w/text_0070.shtml (дата обращения: 25.05.2020).

\section{Исследования}

Бланк К. Мышкин и Обломов // Роман Ф. М. Достоевского «Идиот»: современное состояние изучения. Сборник работ отечественных и зарубежных ученых. М.: ИМЛИ РАН, 2001. С. 472-481.

Долженков П. И. Миф об Эдипе в романе «Обыкновенная история» // Материалы VI Международной научной конференции. Ульяновск: Корпорация технологий продвижения, 2017. С. 7-13.

Краснощекова Е. А. Гончаров. Мир творчества. СПб.: Изд-во Пушкинского фонда, 2012. 528 c.

Лощциц Ю. Гончаров. М.: Молодая гвардия. 1986. 367 с.

Мельник В. И. «Обыкновенная история в ракурсе религиозной концепции // Теория Традиции: христианство и русская словесность. Ижевск: Изд-во «Удмурдский ун-т». 2009. С. 134-162.

Мельник В. И. Гончаров. М.: Вече, 2012. 431 с.

Мельник В. И. Гончаров и православие. Режим доступа: https://libusta.com.ua/ dokumentalnye-knigi/biografii-i-memuary/page-54-45246-vladimir-melnik-goncharovi-pravoslavie.html (дата обращения: 22.02.2021).

Мосалева Г. В. Храмово-корабельная образность в «Обломове» И. А. Гончарова // Вестник Удмуртского университета. Серия История и филология. 2017а. Т. 27. Вып. 5. С. 658-664.

Мосалева Г. В. Храмовые мотивы в «Обыкновенной истории» И. А. Гончарова: отказ героя от храма и метаморфоза образа // Материалы VI Международной научной конференции. Ульяновск: Корпорация технологий продвижения, 20176. C. 26-34.

Мосалева Г. В. Воплощение храмово-литургической модели в романе «Обрыв» И. А. Гончарова: сюжеты жизни и искусства // Уральский филологический вестник. Сер. Русская классика: динамика художественных систем. 2017в. № 4. С. 69-82.

Мосалева Г. В. Литургические аспекты романа И. А. Гончарова «Фрегат “Паллада"» в контексте жанровых трансформаций // Вестник Удмуртского университета. Сер. История и филология. 2018а. Т. 28. Вып. 3. С. 328-334. 
Мосалева Г. В. Образ России как храма-корабля и его модификации в романной поэтике И. А. Гончарова // Вестник Удмуртского университета. Сер. История и филология. 20186. Т. 28. Вып. 2. С. 169-179.

Недзвеикий В. А. Фрегат «Паллада» Гончарова как «географический роман» // Материалы межд. конф., посвященной 180-летию со дня рождения И. А. Гончарова. Ульяновск, 1994. С. 124-137.

Нейчев Н. Таинственная поэтика Ф. М. Достоевского. Екатеринбург: Изд-во Уральского ун-та, 2010.316 с.

Отрадин М. Проза И. А. Гончарова в литературном контексте. СПб: Изд-во С.-Петербургского ун-та, 1994. 169 с.

Пырков И. В. «...А на снегу - щепка». Образ Салтыкова-Щедрина в романе И. А. Гончарова «Обрыв» // Филологические науки. Вопросы теории и практики. Тамбов: Грамота, 2017. № 8 (77): в 2 ч. Ч. 2. С. 48-52. 


\section{References}

Blank, K. "Myshkin i Oblomov" ["Myshkin and Oblomov"]. Roman F. M. Dostoevskogo "Idiot": sovremennoe sostoyanie izucheniia. Sbornik rabot otechestvennykh i zarubezhnykh uchenykh [F. M. Dostoevsky's Novel "The Idiot": Current State of Study. Collection of Works of Domestic and Foreign Scientists]. Moscow, IWL RAS Publ., 2001, pp. 472-481. (In Russ.)

Dolzhenkov, P. I. "Mif ob Edipe v romane 'Obyknovennaia istoriia." [“The Oedipus Myth in the Novel 'A Common Story'."]. Materialy VI mezhdunarodnoi nauchnoi konferentsii [Materials of the $6^{\text {th }}$ International Scientific Conference]. Ulyanovsk, Korporatsiia tekhnologii prodvizheniia Publ., 2017, pp. 7-13. (In Russ.)

Krasnoschekova, E. A. Goncharov. Mir tvorchestva [Goncharov. Creative World]. St. Petersburg, Izdatel'stvo Pushkinskogo fonda Publ., 2012. 528 p. (In Russ.)

Loshchits, Yu. Goncharov [Goncharov]. Moscow, Molodaya gvardiya Publ., 1986. 367 p. (In Russ.)

Melnik, V. I. “'Obyknovennaia istoriia' v rakurse religioznoi kontseptsii” [“'A Common Story' from the Perspective of a Religious Concept"]. Teoriia traditsii: khristianstvo $i$ russkaia slovesnost' [Theory of Tradition: Christianity and Russian Literature]. Izhevsk, Izdatel'stvo “Udmurdskii universitet” Publ., 2009, pp. 134-162. (In Russ.)

Melnik, V. I. Goncharov [Goncharov]. Moscow, Veche Publ., 2012. 431 p. (In Russ.)

Melnik, V. I. Goncharov i pravoslavie [Goncharov and Orthodoxy]. Available at: https:// flibusta.com.ua/dokumentalnye-knigi/biografii-i-memuary/page-54-45246-vladimirmelnik-goncharov-i-pravoslavie.html (Accessed 22 February 2021). (In Russ.)

Mosaleva, G. V. "Khramovo-korabel'naia obraznost' v 'Oblomove’ I. A. Goncharova” ["Imagery of a Temple and a Ship in the Novel 'Oblomov' by I. A. Goncharov"]. Vestnik Udmurtskogo universiteta. Seriia Istoriia i filologiia, issue 5, vol. 27, 2017, pp. 658-664. (In Russ.)

Mosaleva, G. V. "Khramovye motivy v 'Obyknovennoi istorii' I. A. Goncharova: otkaz geroia ot khrama i metamorfoza obraza" ["Temple Motifs in the I. A. Goncharov's 'A Common Story': Hero's Rejection of the Temple and the Metamorphosis of Image"]. Materialy VI mezhdunarodnoi nauchnoi konferentsii [Materials of the $6^{\text {th }}$ International Scientific Conference]. Ulyanovsk, Korporatsiia tekhnologii prodvizheniia Publ., 2017, pp. 26-34. (In Russ.)

Mosaleva, G. V. "Voploshchenie khramovo-liturgicheskoi modeli v romane 'Obryv' I. A. Goncharova: siuzhety zhizni i iskusstva" ["Implementation of the Temple and Liturgic Model in the Novel 'The Precipice' by I. A. Goncharov: Art and Life Storyline"]. Ural'skii filologicheskii vestnik. Seriia Russkaia klassika: dinamika khudozhestvennykh sistem, no. 4, 2017, pp. 69-82. (In Russ.)

Mosaleva, G. V. "Liturgicheskie aspekty romana I. A. Goncharova 'Fregat Pallada' v kontekste zhanrovykh transformatsii" ["Liturgic Aspects of 'The Fregate Pallada' by I. A. Goncharov from the Perspective of Genre Transformations"]. Vestnik Udmurtskogo universiteta. Seriia Istoriia i filologiia, issue 3, vol. 28, 2018, pp. 328-334. (In Russ.)

Mosaleva, G. V. "Obraz Rossii kak khrama-korablia i ego modifikatsii v romannoi poetike I. A. Goncharova" ["The Image of Russia as a Temple-ship and Its Modifications in I. A. Goncharov's Novelistic Poetics"]. Vestnik Udmurtskogo universiteta. Seriia Istoriia i filologiia, issue 2, vol. 28, 2018, pp. 169-179. (In Russ.) 
Nedzvetskii, V. A. "Fregat Pallada' Goncharova kak 'geograficheskii roman." [“'Fregate Pallada' by Goncharov as a 'Geographical Novel.']. Materialy mezhdunarodnoi konferentsii, posviashchennoi 180-letiiu so dnia rozhdeniia I. A. Goncharova [Materials of the International Conference Dedicated to the $180^{\text {th }}$ Anniversary of I. A. Goncharov]. Ulyanovsk, 1994, pp. 124-137. (In Russ.)

Neychev, N. Tainstvennaia poetika F. M. Dostoevskogo [Mysterious Poetics of F. M. Dostoevsky]. Yekaterinburg, Izdatel'stvo Ural'skogo universiteta Publ., 2010. 316 p. (In Russ.)

Otradin, M. Proza I. A. Goncharova v literaturnom kontekste [I. A. Goncharov's Prose in the Literary Context]. St. Petersburg, Izdatel'stvo S.-Peterburgskogo universiteta Publ., 1994. 169 p. (In Russ.)

Pyrkov, I. V. “'...A na snegu - shchepka. Obraz Saltykova-Shchedrina v romane I. A. Goncharova 'Obryv'.” [“....And on the Snow - a Splinter'. The Image of SaltykovShchedrin in I. A. Goncharov's Novel 'The Precipice."']. Filologicheskie nauki. Voprosy teorii i praktiki, no. 8 (77), in 2 parts, part 2, 2017, pp. 48-52. (In Russ.) 


\title{
Духовные искания Автора в первой главе романа «Евгений Онегин»
}

\begin{abstract}
Аннотация: Автор статьи, указывая на устойчивые в научном пушкиноведении определения романа «Евгений Онегин» - реалистический, исторический, философский, автобиографический и проблемный, - отмечает, что роман полон мистики, понимая под мистикой веру в существование сверхъестественных метафизических сил, с которыми так или иначе и герои, и сам Автор романа связаны таинственным образом. В статье рассматриваются причины духовного кризиса Онегина, который проявляется в мировидении и поведении героя. Его важнейшие черты, названные в романе, - коварство, лицемерие, цинизм, безделье, искаженное представление о любви, которую заменяет «наука страсти нежной», - рассматриваются в сопоставлении с текстами Священного Писания. В результате автор статьи приходит к выводу, что состояние души главного героя может быть охарактеризовано как ее «омертвение» или «окаменение». «Недуг, которого причину давно бы отыскать пора», связан не столько, может быть, с жизнью в «омуте света», сколько с утратой веры в Бога, «потерей себя» под латентным воздействием демонических сил.

Ключевье слова: Пушкин, роман, «Евгений Онегин», мистика, Лотман, Набоков, комментарий, духовный кризис.
\end{abstract}

Информация об авторе: Виктор Андреевич Кожевников, старший научный сотрудник, Институт мировой литературы им. А. М. Горького Российской академии наук, ул. Поварская, д. 25 а, 121069 г. Москва, Россия.

E-mail: Polina50@list.ru

Дата поступления статьи в редакиию: 01.06 .2021

Дата одобрения статьи рецензентами: 17.07.2021

Дата публикации статьи: 30.09.2021

Для цитирования: Кожевников В. А. Духовные искания Автора в первой главе романа «Евгений Онегин» // Два века русской классики. 2021. Т. 3, № 3. С. 104-123. https://doi.org/10.22455/2686-7494-2021-3-3-104-123 


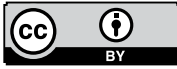

This is an open access article distributed under the Creative Commons Attribution

4.0 International (CC BY 4.0)
Dva veka russkoi klassiki,

vol. 3, no. 3, 2021, pp. 104-123. ISSN 2686-7494

Two centuries of the Russian classics, vol. 3, no. 3, 2021, pp. 104-123. ISSN 2686-7494

Research Article

(C) 2021. Victor A. Kozhevnikov

A. M. Gorky Institute of World Literature of the Russian Academy of Sciences

Moscow, Russia

\title{
Spiritual Quest of the Author in the First Chapter of the Novel Eugene Onegin
}

\begin{abstract}
The author of the article, pointing to the definitions of the novel Eugene Onegin that are stable in scientific Pushkin studies - realistic, historical, philosophical, autobiographical and problematic - notes that the novel is full of mysticism, understanding by mysticism a belief in the existence of supernatural metaphysical forces, with which the heroes, and the author of the novel himself, are connected in a mysterious way. The article examines the reasons for Onegin's spiritual crisis, which manifests itself in the worldview and behavior of the hero. Its most important features, named in the novel - deceit, hypocrisy, cynicism, idleness, a distorted idea of love, which is replaced by "the science of tender passion" - are considered in comparison with the texts of Holy Scripture. As a result, the author of the article comes to the conclusion that the state of the protagonist's soul can be characterized as its "mortification" or "petrification". "The disease, the cause of which should have been found long ago", is connected not so much, perhaps, with life in the "pool of light" as with the loss of faith in God, "loss of oneself" under the latent influence of demonic forces.
\end{abstract}

Keywords: Pushkin, novel, Eugene Onegin, mysticism, Lotman, Nabokov, commentary, spiritual crisis.

Information about the author: Viktor A. Kozhevnikov, Senior Researcher, A. M. Gorky Institute of World Literature of the Russian Academy of Sciences, Povarskaya 25 a, 121069 Moscow, Russia.

E-mail: Polina50@list.ru

Received: June 01, 2021

Approved after reviewing: July 17, 2021

Published: September 30, 2021

For citation: Kozhevnikov, V A. "Spiritual Quest of the Author in the First Chapter of the Novel Eugene Onegin." Dva veka russkoi klassiki, vol. 3, no. 3, 2021, pp. 104-123. (In Russ.) https://doi.org/10.22455/2686-7494-2021-3-3-104-123 
«Евгений Онегин» - главное произведение А. С. Пушкина, всесторонне изученное и проанализированное. Научный комментарий к нему, созданный не одним поколением выдающихся ученых, можно назвать вершиной не только науки о Пушкине, но и всего литературоведения в целом. Тем не менее и в этом фундаментальном труде встречаются локальные «белые пятна» и темы, которые нуждаются по крайней мере в дополнениях, важных для понимания сущностных проблем романа. Это в первую очередь касается проблем, связанных с едва затронутой наукой о Пушкине темой мистики, под которой мы понимаем веру в существование сверхъестественных метафизических сил (боги, ангелы, духи, демоны и прочие нематериальные сущности), а также, что гораздо важнее, влияния этой веры на характеры, мировидение и поведение героев. Без этого наши представления о романе едва ли можно было бы назвать полными.

«Евгений Онегин» - «энциклопедия русской жизни» и «самое задушевное произведение Пушкина» [Белинский 7: 503, 431] - роман, конечно, реалистический [Мейлах: 417], т. е. правдиво воспроизводящий эпоху и наше бытие. При этом «в “Онегине” мы видим поэтически воспроизведенную картину русского общества, взятого в одном из интереснейших моментов его развития. С этой точки зрения, - писал Белинский, - “Евгений Онегин” есть поэма историческая в полном смысле слова» (курсив мой. - В. К.) [Белинский 7: 432].

«Момент» действительно интереснейший: в романе изображена «картина русского общества» первой трети XIX в. - до и после восстания декабристов. Правда, в комментариях В. В. Набокова [Набоков] и Ю. М. Лотмана [Лотман] указано что действие романа заканчивается весной 1825 г. (здесь исследователь дословно повторяет выводы Иванова-Разумника без ссылки на источник [Иванов-Разумник: 48-113]).

Между тем достаточно внимательно прочитать Восьмую главу романа, чтобы убедиться: в ней изображена эпоха конца 1820-х - начала 
1830-х гг. XIX в. На это, к примеру, указывают десяток «хронологических помет» и «на эпиграммы падкий» господин. Он был очень сердит

На толки про роман туманный, На вензель, двум сестрицам данный, На ложь журналов, на войну...

[Пушкин 1937-1949. 6: 176].

«Толки про роман туманный» - это, конечно, «Толки о “Евгении Онегине” - так называлась статья Н. А. Полевого в журнале «Московский телеграф» [Полевой]. А туманным роман Пушкина назвал, вероятно, М. П. Погодин, подписавший статью инициалами «N. N.»: «Мы подслушивали разные суждения и расскажем их $\langle\ldots>$. Нить повествования ведена лучше в первых трех песнях, чем в последних двух, замечают также многие. Читатель по прочтении четвертой и пятой остается в каком-то тумане...» (курсив мой. - В. К.) [N. N. 1828: 461 и 464].

И «Вензель, двум сестрицам данный», - примета более позднего времени. «Две сестрицы» (или, как обозначено в черновиках, «две сиротки» [Пушкин 1937-1949. 6: 511]) - Анастасия и Ольга Бороздины. Они стали фрейлинами (это и называлось - получить вензель) после смерти их отца Николая Михайловича Бороздина, генерал-адъютанта, любимца императора Николая I, особо назначенного чиновника Верховного уголовного суда и Следственной комиссии по делу декабристов. Умер Николай Михайлович Бороздин 14 ноября 1830 г.

И «Ложь журналов» - примета более позднего времени: речь здесь идет о журнальной «полемике» конца 1820-х - начала 1830-х гг., полной взаимных оскорблений и нападок, негативно воспринятой в обществе. В это время «торговые журналисты» - Полевой, Булгарин, Греч - травили Пушкина и «литературных аристократов», позволяя себе недостойные выпады. «Но из ув.<ажения > к себе не должно по лености или добродушию оставлять без внимания оскорб.<ительные > лич.<ности> и клеветы, ныне к несчастию слишком обыкновенные» [Пушкин 19371949. 9: 166], — так писал Пушкин осенью 1830 г. в статье «Опыт отражения некоторых нелитературных обвинений».

Ворчание «сердитого господина» «На войну» было, по-видимому, связано с недовольством итогами русско-турецкой войны 1828 1829 гг. или ходом Польского восстания 1830 г. Последнее вероятнее: 
в черновиках прямо сказано: «...На Польшу...» [Пушкин 1937-1949. 6: 511] [Кожевников: 111-167].

«Евгений Онегин» - действительно роман реалистический, исторический, а ещё это - «первый русский проблемный роман, - отметил В. С. Непомнящий, - и проблема его - проблема человека, она ставится, рассматривается, решается на протяжении всего романа. Решается, иными словами, вопрос: что такое человек? Физическое, «природное» естество, «животное, которое рассуждает» (Д. Дидро), как учит французский материализм, или сверхприродное, духовное существо? Тварь, руководствующаяся, подобно животному, только наличными “потребностями” и хотениями, или создание, которому свойственно стремиться к высоким, идеальным, духовным целям и руководствоваться совестью? Сама природа такой проблемы неисчерпаема, и это первая причина неисчерпаемого динамизма романа» (курсив автора текста. B. К.) [Непомнящий 2001: 73].

«Евгений Онегин» - роман автобиографический, обе героини, Ольга и Татьяна Ларины, и оба героя, Ленский и Онегин, - ипостась самого Автора, его роман в стихах - это своего рода дневник его духовной жизни, фиксирующий его духовные искания на протяжении восьми лет работы над романом, и в этом смысле это роман философский. И «Евгений Онегин» полон мистики: многое, если не всё, зависит в таком случае от веры в Бога, суеверия или безверия Автора и его героев.

Пушкин, сочинитель антиклерикальной поэмы «Монах», кощунственной «Гавриилиады» и прочих антицерковных «шалостей», склонный к суеверию, начал писать роман «Евгений Онегин» в мае 1823 г. Это был период жестокого духовного кризиса, в течение которого ничто: ни его произведения, ни его поведение - не могло бы свидетельствовать об изменении его прежних религиозных взглядов, далеких от Православия.

Это было время, когда Поэт сам чувствовал, что его одолевает страшный недуг «омертвения души».

Собственно говоря, роман «Евгений Онегин» об этом - о превращении живого человека, с которым Автор подружился и заметил в нем не только «резкий, охлажденный ум», но и «мечтам невольную преданность», в человека «угрюмого» («Я был озлоблен, он угрюм» [Пушкин 1937-1949. 6: 23]), циничного, с душой холодной, равнодушной, умирающей. 
«Мертвые души» не с Гоголя начинаются. И не с Пушкина. Вспомним притчу о призвании Христом апостолов, учеников Своих: «Другой же из учеников Его сказал Ему: Господи! позволь мне прежде пойти и похоронить отца моего. Но Иисус сказал ему: иди за Мною, и предоставь мертвым погребать своих мертвецов» (курсив мой. - В. К.) [Мф. 8: 21-22]. «Роман в стихах» начинается с полусонного, «смутно-дремотного» [Набоков: 103] «бормотания» главного героя, едущего за наследством в деревню к умирающему дяде:

«Мой дядя самых честных правил,

Когда не в шутку занемог,

Он уважать себя заставил

И лучше выдумать не мог.

Его пример другим наука;

Но, Боже мой, какая скука

С больным сидеть и день и ночь,

Не отходя ни шагу прочь!

Какое низкое коварство

Полуживого забавлять,

Ему подушки поправлять,

Печально подносить лекарство,

Вздыхать и думать про себя:

Когда же чёрт возвмет тебя!»

[Пушкин 1937-1949. 6: 5]

Монолог Онегина с поминанием чёрта характеризует героя как человека далекого от религиозного благочестия, циничного и подверженного «афеизму» ${ }^{1}$, а кроме этого, включает в себя аллюзию на роман Байрона «Дон-Жуан», первая строфа которого тоже заканчивается «чертовщиной»:

Ищу героя! Нынче что ни год

Являются герои, как ни странно

Им пресса щедро славу воздает,

${ }^{1}$ Афеизм (устар.) - то же, что атеизм - безбожие, безверие. Ср. у Пушкина: «беру уроки чистого афеизма» [Пушкин 1937-1949. 13: 92]. 
Но эта лесть, увы, непостоянна

Сезон прошел - герой уже не тот,

А посему я выбрал Дон-Жуана

Ведь он, наш старый друг, в расцвете сил

Со сцены прямо к черту угодил.

(курсив мой. - В. К.) [Байрон]

Евгений Онегин, подобно герою английского поэта Джорджа Байрона, тоже прямо к черту угодил, причем еще задолго до отъезда в деревню. В сущности вся Первая глава об этом: как Онегин, сам того не зная и не понимая, угодил в бесовские сети соблазнов и страстей.

Есть в первой строфе еще один намек - на роман английского (ирландского) священника Чарльза Метьюрина «Мельмот Скиталец». Начинается он с рассказа о том, как молодой студент Джон Мельмот едет в деревню, за наследством, к своему умирающему дяде и здесь, в замке дяди ${ }^{1}$, видит призрак, а потом узнает историю своего далекого мистического предка Мельмота Скитальца, который лет сто семьдесят тому назад продал душу дьяволу.

Герой английского романа - жертва искусителя, обреченная против собственной воли творить зло.

«Восклицание Онегина, - писал Юрий Михайлович Лотман о последней строке первой строфы, - вносит, с одной стороны, в сюжетное начало романа элемент пародии, а с другой - раскрывает параллель Онегин - Мельмот как элемент самооценки героя, на которую Автор смотрит иронически» [Лотман: 120]. Ироническая интонация, даже если она есть, не зачеркивает серьезности поставленной Пушкиным проблемы - создать «портрет» героя, душа которого «окаменела»:

В мертвящем упоеньи света,

Среди бездушных гордецов,

Среди блистательных глупцов,

1 Не случайно деревенский дом дяди Онегина тоже назван за́мком: «Почтенный замок был построен, / Как замки строиться должны» [Пушкин 1937-1949. 6: 31]. 


\section{XLVII}

Среди лукавых, малодушных, Шальных, балованных детей, Злодеев и смешных и скучных, Тупых, привязчивых судей, Среди кокеток богомольных, Среди холопьев добровольных, Среди вседневных, модных сцен Учтивых, ласковых измен, Среди холодных приговоров Жестокосердой суеты, Среди досадной пустоты Расчетов, дум и разговоров, В сем омуте, где с вами я Купаюсь, милые друзья. (курсив мой. - В. К.) [Пушкин 1828: 45-46]

Этими стихами заканчивалась шестая глава романа, которая отдельным изданием вышла 23 марта 1828 г. А предшествовали этому окончанию семь «молитвенных» строк:

А ты, младое вдохновенье, Волнуй мое воображенье, Дремоту сердца оживляй, В мой угол чаще прилетай, Не дай остыть душе поэта, Ожесточиться, очерстветь, И наконеи, окаменеть, В мертвящем упоеньи света.

(курсив мой. - В. К.) [Пушкин 1828: 44-45]

Пушкин очень болезненно ощущал «окаменение» своей души, ее омертвение. И в главе седьмой, описывая свое состояние духовной опустошенности, и восклицал и вопрошал горестно:

С каким тяжелым умиленьем

Я наслаждаюсь дуновеньем 
В лицо мне веющей весны,

На лоне сельской тишины!

Или мне чуждо наслажденье,

И всё, что радует, живит,

Всё, что ликует и блестит,

Наводит скуку и томленье

На душу мертвую давно,

И всё ей кажется темно?

(курсив мой. - В. К.) [Пушкин 1937-1949. 6: 139-140]

Ощущение себя «мертвой душой» - состояние едва ли не трагическое, но в то же время и верное свидетельство того, что душа еще все-таки жива: «настоящие» «мертвые души» своей «мёртвости» не осознают. Как не осознавали ее родственники апостола, призванного Христом к служению.

Омертвение души - следствие безверия и потери Бога, на месте которого появляется пустота или некий фантом - невидимая и таинственная Судьба - «по религиозным представлениям - высшая сила или воля божества, предопределяющая всё, что происходит в жизни» [Словарь языка Пушкина 4: 423]. Иногда Судьба добра и милосердна («Судьба Онегина хранила...») [Пушкин 1937-1949. 6: 6], а чаще завистлива и зла. Но и «счастливые» дары сей капризной дамы могут обернуться для ее «любимцев» катастрофой. Снедаемый тоской, с разочарованной, мертвеющей душой Онегин, сам того не понимая, оказался во власти неведомых и невидимых демонических сил, присутствие которых весной, летом и осенью 1823 г. Пушкин, работая над Первой главой романа (окончена 22 октября), ощущал особенно остро. Даже чтение Библии его иногда раздражало. Особенно, когда он чувствовал надзор над собой. Вот какую историю рассказала Пелагея Васильевна Дыдицкая - племянница архимандрита Иринея, а записал её и опубликовал Лев Степанович Мацеевич - библиофил, церковный журналист, историк, литературовед, инспектор Кишиневской духовной семинарии.

Дядя Ириней часто ездил к Инзову в дом. Инзов просил дядю, чтобы он почаще беседовал с Пушкиным и наставлял его. Раз, помню, случилось так. Приезжает дядя к Инзову в страстную пятницу. Поговорил с ним немного и 
потом спрашивает: а где же Александр Сергеевич? - «Да он там - у себя в своей комнате - чем-то занимается». - Я пойду к нему, поговорю с ним, сказал дядя. - Входит дядя в комнату Пушкина, - а он сидит и что-то читает. - Чем это вы занимаетесь? - спросил его дядя, поздоровавшись. - «Да вот читаю историю одной особы», или нет, помню, еще не так он сказал - не особы, а «читаю, говорит, историю одной статуи». Дядя посмотрел на книгу, а это было Евангелие! Дядя очень вспылил и рассердился, ибо он был, действительно, строгий и горячий. - «Что это вы сказали? Как вы смеете так говорить? Вы безбожник! Я на вас сейчас же бумагу подам - и вас за это строжайше накажут». Много и сильно бранил Пушкина дядя и уехал рассерженный. На другой день Пушкин приезжает в семинарию - и ко мне: «так и так, говорит, боюсь, чтоб ваш дядя не донес на меня... Просите, просите вашего дядю». - Зачем же вы, говорю, так не хорошо сказали? - «Да так, говорит, само как-то с языка слетело» [Мацеевич: 391-392].

Но «время изменяет человека как в физическом, так и в духовном отношении. <...> Глупец один не изменяется, ибо время не приносит ему развития, а опыта для него не существует...» [Пушкин 1937-1949. 12: 34]. И в 1826 г., когда был написан «Пророк», и в 1836 г., незадолго до гибели, Пушкин думал уже иначе:

Есть книга, коей каждое слово истолковано, объяснено, проповедано во всех концах земли, применено ко всевозможным обстоятельствам жизни и происшествиям мира; из коей нельзя повторить ни единого выражения, которого не знали бы все наизусть, которое не было бы уже пословицею народов; она не заключает уже для нас ничего неизвестного; но книга сия называется Евангелием, - и такова ее вечно-новая прелесть, что если мы, пресыщенные миром или удрученные унынием, случайно откроем ее, то уже не в силах противиться ее сладостному увлечению, и погружаемся духом в ее божественное красноречие [Пушкин 1937-1949. 12: 99].

Но и тогда, в 1823 г., переживая тяжелейший духовный кризис, Пушкин, читая Библию («Я слишком с Библией знаком») [Пушкин 1937-1949. 2: 291], не мог хотя бы душой поэта не ощутить «божественное красноречие» Священного Писания, в котором все пороки человеческие и названы, и описаны. Интересно сопоставить «симптомы» онегинского недуга с библейскими текстами. 
Онегин - герой «обыкновенный». В описании его светской петербургской жизни нет ничего необычного, ничего демонического, ничего инфернального или мистического. Но ведь не просто так и не случайно Автор чуть позже назвал Онегина искусителем, бесом. Татьяна, когда писала Онегину свое трогательное письмо с объяснением в любви, не могла еще решить для себя:

Кто ты, мой ангел ли хранитель

Или коварный искуситель:

Мои сомненья разреши...»

(курсив мой. - В. К.) [Пушкин 1937-1949. 6: 67]

Между тем Автор уже - для себя — «разрешил» ее сомненья:

Татьяна, милая Татьяна!

С тобой теперь я слезы лью;

Ты в руки модного тирана

Уж отдала судьбу свою.

Погибнешь, милая; но прежде

Ты в ослепительной надежде

Блаженство темное зовешь,

Ты негу жизни узнаешь,

Ты пьешь волшебный яд желаний,

Тебя преследуют мечты:

Везде воображаешь ты

Приюты счастливых свиданий;

Везде, везде перед тобой

Твой искуситель роковой.

(курсив мой. - В. К.) [Пушкин 1937-1949. 6: 57-58]

Искуситель - по «Словарю...» В. И. Даля - «соблазнитель, прельститель, совращатель <...>; лукавый, сатана, дьявол» [Даль 2: 51] - толкование, восходящее к Евангелию: «Тогда Иисус возведен был Духом в пустыню, для искущения от диавола, и, постившись сорок дней и сорок ночей, напоследок взалкал. И приступил к Нему искуситель...» [Мф 4: 1-3].

Онегин, конечно, душу дьяволу не продавал, в отличие от героя Метьюрина, но присутствие беса, на которого намекнул Пушкин в начале 
романа, очевидно. Светский образ жизни Онегина - естественный в «омуте» ${ }^{1}$ дворянской среды - это мир перевернутых ценностей, мир бесовских искушений, страстей и омертвения души.

Почему Онегина, хранимого судьбой, вдруг мертвой хваткой стал душить «Недуг, которого причину / Давно бы отыскать пора»? [Пушкин 1937-1949. 6: 21]. Причин, видимых и невидимых, было и остается великое множество. Отметим одну, названную в романе, - душевная nycmoma:

И снова, преданный безделью,

Томясь душевной пустотой,

Уселся он - с похвальной целью

Себе присвоить ум чужой;

Отрядом книг уставил полку,

Читал, читал - а всё без толку...

(курсив мой. - В. К.) [Пушкин 1937-1949. 6: 23]

Пустота лишь на первый взгляд — и не болезнь, и неопасна.

На самом деле пустота души - недуг смертельный, как и сказано в Писании: «Я неисиельно поражу тебя опустошением за грехи твои. Ты будешь есть и не будешь сыт; nустота будет внутри тебя; будешь хранить, но не убережешь, а что сбережешь, то предам мечу. Будешь сеять, а жать не будешь; будешь давить оливки и не будешь умащаться елеем; выжмешь виноградный сок, а вина пить не будешь» (Мих. 6: 13-15).

«Свято место пусто не бывает...», а если оно пусто и не свято - известно, кто его займет. Пустота - место беса; признак умирания или омертвения души. И «плоды» этого омертвения - от «древа злого»: «Так всякое дерево доброе приносит и плоды добрые, а худое дерево приносит и плоды худые. <...> Итак, по плодам их узнаете их» (Мф 7: $17-20)$.

1 Омут - на поверхности тихое и спокойное, но самое глубокое и гибельное место в реке или в озере с очень сильным водоворотом, который затягивает свои жертвы на дно. Выбраться из него трудно, почти невозможно. По народным представлениям, место обитания нечисти. Свет омут: «В сем омуте, где с вами я / Купаюсь, милые друзья!» - метафора прозрачная: «в тихом омуте черти водятся». 
Вся Первая глава, а по сути, и весь роман повествуют об этих отравленных, ядовитых «плодах». Что больше всего занимало Онегина?

«Наука страсти нежной, / Которую воспел Назон...» - древнеримский поэт Публий Овидий Назон создал монументальный триптих из дидактических элегий «Наука любви», «Наука любить» и «Искусство любви», описывающих основы учтивого поведения мужчин и женщин, а также различные приёмы и уловки соблазнения. «Наука любви» - одно из самых эротичных произведений в мировой литературе. В сущности, трилогию Овидия можно назвать искусством и наукой не любви, а соблазнения и разврата.

Сравним у Пушкина:

Чем меньше женщину мы любим,

Тем легче нравимся мы ей,

И тем ее вернее губим

Средь обольстительных сетей.

Разврат, бывало, хладнокровный

Наукой славился любовной,

Сам о себе везде трубя,

И наслаждаясь не любя.

(курсив мой. - В. К.) [Пушкин 1937-1949. 6: 75]

Овидиевы «Искусство любви» и «Наука любви» никакого отношения к любви не имеют, ибо в основе этих «игрищ» лежит эгоистическое и самолюбивое желание ублажить себя. А безыскусная настоящая любовь «не ищет своего», о чем писал апостол Павел: «Любовь долготерпит, милосердствует, любовь не завидует, любовь не превозносится, не гордится, не бесчинствует, не ищет своего, не раздражается, не мыслит зла, не радуется неправде, а сорадуется истине; все покрывает, всему верит, всего надеется, все переносит» (1 Кор. 13: 4-7).

Сравним в портрете Ленского:

От хладного разврата света

Еще увянуть не успев,

Его душа была согрета

Приветом друга, лаской дев...

(курсив мой. - В. К.) [Пушкин 1937-1949. 6: 34] 
И вот онегинские «плоды» «науки страсти нежной» - в сопоставлении с текстами Священного Писания.

«Какое низкое коварство / Полуживого забавлять...» [Пушкин 1937-1949. 6: 5] - рассуждает Онегин, как будто есть высокое коварство. Но сказано в Притчах Соломоновых: «Промышления праведных - правда, а замыслы нечестивых - коварство» (Притчи 12: 5). Коварство - это притворство, злой умысел, предательство, «иудин поцелуй», вероломство, ложь и лицемерие. «Как рано мог он лицемерить...» [Пушкин 1937-1949. 6: 9], - сказано в романе. И в Притчах Соломоновых сказано: «Устами лицемер губит ближнего своего...» (Притчи 11: 9). И себя, конечно, губит. Лицемерие - это ложь. И об этом сказано в Притчах: «Мерзость пред Господом - уста лживые» (Притчи 12: 22).

И в Евангелии от Иоанна то же самое сказано о лжецах и лицемерах: «Ваш отец диавол; и вы хотите исполнять похоти отца вашего. Он был человекоубийца от начала и не устоял в истине, ибо нет в нём истины. Когда говорит он ложь, говорит своё, ибо он лжец и отец лжи» (Ин. 8: 44). И в дальнейшем мы видим, что «моральный кодекс» Онегина «перевертыш» Заповедей Божиих. Вместо любви, без которой человек «ничто» (1 Кор. 13: 2), потому что «Бог есть любовь» (1 Ин 4: 8), — «наука страсти нежной», наука прелюбодеяния и разврата.

Вместо дружбы - иллюзия, пустая видимость «дружества» - «от делать нечего» (курсив автора текста. - В. К.) [Пушкин 1937-1949. 6: 37]. В итоге: «Друзья и дружба надоели» [Пушкин 1937-1949. 6: 21]. А могло быть и должно быть иначе: «Отдаляйся от врагов твоих и будь осмотрителен с друзьями твоими. Верный друг - крепкая защита: кто нашел его, нашел сокровище. Верному другу нет цены, и нет меры доброте его. Верный друг - врачевство для жизни, и боящиеся Господа найдут его» (Сирах 6: 13-16).

Вместо труда - отвращение к нему: «Но труд упорный / Ему был тошен...» [Пушкин 1937-1949. 6: 22].

Вместо любви к родным - лицемерное «почитание» и раздражение:

Мы их обязаны ласкать, Любить, душевно уважать

И, по обычаю народа,

О рождестве их навещать, 
Или по почте поздравлять,

Чтоб остальное время года

Не думали о нас они...

(курсив мой. - В. К.) [Пушкин 1937-1949. 6: 81]

Вместо любви к ближнему своему и врагам своим, которых тоже надо любить, - «любите врагов ваших, благословляйте проклинающих вас, благотворите ненавидящим вас и молитесь за обижающих вас и гонящих вас» (Мф. 5: 44) - злословие, злоречие:

Когда ж хотелось уничтожить

Ему соперников своих,

Как он язвительно злословил!

Какие сети им готовил!

(курсив мой. - В. К.) [Пушкин 1937-1949. 6: 10]

А премудрый Соломон говорит: «Берегитесь от злоречия языка, ибо и тайное слово не пройдет даром, а клевещущие уста убивают душу» (Прем. 1: 11). И апостол Павел учит: «Всякое раздражение и ярость, и гнев, и крик, и злоречие со всякою злобою да будут удалены от вас; но будьте друг ко другу добры, сострадательны, прощайте друг друга, как и Бог во Христе простил вас» [Эфес 4: 31-32].

И сети - орудие бесовского арсенала: «Ищущие же души моей ставят сети, и желающие мне зла говорят о погибели моей и замышляют всякий день козни» (курсив автора текста. - В. К.) (Пс. 37: 13).

Стоит ли удивляться, что Онегина ждали в итоге разочарование, сплин, хандра, охлаждение чувств, омертвение души и мысли о самоубийстве. «Евгений Онеги» - роман автобиограбический, если иметь в виду идентичность духовных катастроф героя и Автора.

В сентябре-октябре 1822 г., за полгода или чуть больше до начала «Онегина», Пушкин написал письмо брату, которое можно назвать планом-«конспектом» Первой главы романа:

Тебе придется иметь дело с людьми, которых ты еще не знаешь. С самого начала думай о них все самое плохое, что только можно вообразить: ты не слишком сильно ошибешься. Не суди о людях по собственному сердцу, которое, я уверен, благородно и отзывчиво и, сверх того, еще молодо; 
презирай их самым вежливым образом: это - средство оградить себя от мелких предрассудков и мелких страстей, которые будут причинять тебе неприятности при вступлении твоем в свет.

Будь холоден со всеми; фамильярность всегда вредит; особенно же остерегайся допускать ее в обращении с начальниками, как бы они ни были любезны с тобой. Они скоро бросают нас и рады унизить, когда мы меньше всего этого ожидаем.

Не проявляй услужливости и обуздывай сердечное расположение, если оно будет тобой овладевать: люди этого не понимают и охотно принимают за угодливость, ибо всегда рады судить о других по себе.

Никогда не принимай одолжений. Одолжение, чаще всего, — предательство. - Избегай покровительства, потому что это порабощает и унижает.

Я хотел бы предостеречь тебя от обольщений дружбы, но у меня не хватает решимости ожесточить тебе душу в пору наиболее сладких иллюзий. То, что я могу сказать тебе о женщинах, было бы совершенно бесполезно. Замечу только, что чем меньше любим мы женщину, тем вернее можем овладеть ею. Однако забава эта достойна старой обезьяны XVIII столетия. Что касается той женщины, которую ты полюбишь, от всего сердца желаю тебе обладать ею.

Никогда не забывай умышленной обиды, - будь немногословен или вовсе смолчи и никогда не отвечай оскорблением на оскорбление.

Если средства или обстоятельства не позволяют тебе блистать, не старайся скрывать лишений; скорее избери другую крайность: цинизм своей резкостью импонирует суетному мнению света, между тем как мелочные ухищрения тщеславия делают человека смешным и достойным презрения.

Никогда не делай долгов; лучше терпи нужду; поверь, она не так ужасна, как кажется, и во всяком случае она лучше неизбежности вдруг оказаться бесчестным или прослыть таковым.

Правила, которые я тебе предлагаю, приобретены мною ценой горького опыта. Хорошо, если бы ты мог их усвоить, не будучи к тому вынужден. Они могут набавить тебя от дней тоски и бешенства [Пушкин 1937-1949. 13: 524; ориг. по-франи.].

А через полгода после начала романа, в октябре-ноябре 1823 г., Пушкин описал воображаемые встречи с тем, кто искушал его в Петербурге и в Кишиневе, кто «диктовал» ему это письмо брату, кто Онегину внушал мысли и лицемерные, и лукавые. 
Демон

В те дни, когда мне были новы

Все впечатленья бытия -

И взоры дев, и шум дубровы,

И ночью пенье соловья,-

Когда возвышенные чувства,

Свобода, слава и любовь

И вдохновенные искусства

Так сильно волновали кровь,

Часы надежд и наслаждений

Тоской внезапной осеня,

Тогда какой-то злобный гений

Стал тайно навещать меня.

Печальны были наши встречи:

Его улыбка, чудный взгляд,

Его язвительные речи

Вливали в душу хладный яд.

Неистощимой клеветою

Он провиденье искушал;

Он звал прекрасное мечтою;

Он вдохновенье презирал;

Не верил он любви, свободе;

На жизнь насмешливо глядел -

И ничего во всей природе

Благословить он не хотел.

1823, октябрь ... ноябрь

[Пушкин 1937-1949. 2: 299].

Принято думать, что «Демон» - отражение кризисного состояния Пушкина. И это отчасти справедливо, потому что «Демон» - стихотворение о прошлом, недавнем, но уходящем. В нем глаголы только прошедшего времени, того незабываемого времени, когда Поэту были «новы / Все впечатленья бытия».

Но «Демон» - стихотворение-переживание и настоящего, мистический ключ к пониманию романа, по крайней мере, Первой главы его, 
которую Пушкин закончил в Одессе 22 октября 1823 г., когда «прояснился темный ум» [Пушкин 1937-1949. 6: 30].

«Демон» - плод прояснения ума, осознания зла - первый шаг избавления от его темной силы. Именно так это стихотворение понял Жуковский: «Обнимаю тебя за твоего Демона. К черту черта! Вот пока твой девиз. Ты создан попасть в боги - вперед. Крылья у души есть! вышины она не побоится, там настоящий ее элемент! дай свободу этим крыльям, и небо твое. Вот моя вера. Когда подумаю, какое можешь состряпать для себя будущее, то сердце разогреется надеждою за тебя. Прости, чертик, будь ангелом» [Пушкин 1937-1949. 13: 94-95].

В. А. Жуковский верил, что душа Поэта обратится к Небу. И Пушкин чувствовал: Жуковский прав. Но до исцеления и даже выхода из кризиса было еще далеко.

В Первой главе, реалистически описывающей события жизни Онегина, мистика латентна и не очень заметна. Она скрыта в намеках и аллюзиях, зато ясно показан гибельный результат ее воздействия на душу героя. Однако в следующих главах мистика заметно проявляется уже в темах споров и рассуждений героев о вековых предрассудках, о роковых тайнах гроба и жизни, о добре и зле, о судьбе и страстях. Мистическими переживаниями проникнуто письмо Татьяны. Прямо связаны с мистикой подробно описанные в романе гадания и сон Татьяны, ее суждения об Онегине. Следующие главы полны реминисценций из Священного Писания и «мистической» лексики: «священные друзья», «неотразимые лучи», «бессмертная семья»; судьба, доля, Рок, роковой; масленица, подблюдны песни, гадания; молебен, коварный искуситель, бес; Бог, воля Неба и Провидение... Мистические представления о мире Автора и его героев играют очень важную роль в «Евгении Онегине», и в Первой, и в последующих главах. Но всё это требует детального рассмотрения, изучения и отдельного исследования. 


\section{Список литературы \\ Источники}

Байрон Дж. Г. Дон-Жуан // Байрон Дж. Г. Собр. соч.: в 4 т. М.: Правда, 1981. Т. 1. URL: http://lib.ru/POEZIQ/BAJRON/donjuan.txt (дата обращения: 21.05.2021).

Белинский В. Г. Статьи о Пушкине // Белинский В. Г. Полн. собр. соч.: в 13 т. М.: Изд-во Акад. наук СССР, 1953-1959. T. VII. С. 99-182.

Даль В. И. Толковый словарь живого великорусского языка: в 4 т. СПб.: Изд-е М. О. Вольфа, 1880-1882.

Мацеевич Л. Кишиневские предания о Пушкине. Рассказ П. В. Дыдицкой // Исторический вестник. 1883. Май. URL: https://runivers.ru/bookreader/ book482965/\#page/433/mode/1up (дата обращения: 21.05.2021).

N. N. Евгений Онегин, роман в стихах, сочинение Александра Пушкина, песнь 4 и 5. СПб.: В тип. Департамента Народного Просвещения // Московский вестник. 1828. Ч. VII. № 4. С. 461-468.

Полевой Н. А. «Толки о “Евгении Онегине”»// Московский телеграф. 1825. № 15. Особенное прибавление.

Пушкин А. С. Полн. собр. соч. М.; Л.: Изд-во АН СССР, 1937-1949, т. I-XVI; 1959, т. XVII (Справочный).

Пушкин А. С. «Евгений Онегин», роман в стихах. СПб.: Тип. Департамента народного просвещения, 1828. $48 \mathrm{c}$.

Словарь языка Пушкина: в 4 т. М.: Гос. изд-во иностр. и нац. языков, 1956-1961. T. IV (C—Я), 1961. 1048 c.

\section{Исследования}

Иванов-Разумник Р. В. Сочинения. Пг.: Тип. М. М. Стасюлевича, 1916. Т. 5.371 с.

Кожевников В. А. Избранное. Статьи, переводы, комментарии. М.; СПб.: Нестор-История, 2017. $431 \mathrm{c.}$

Лотман Ю. М. Роман А. С. Пушкина «Евгений Онегин». Комментарий. Пособие для учителя. Л.: Просвещение, 1983. 416 с.

Мейлах Б. С. «Евгений Онегин»// Пушкин. Итоги и проблемы изучения. М.; Л.: Наука, 1966. 664 с.

Набоков В. В. Комментарий к роману А. С. Пушкина «Евгений Онегин» / пер. с англ. СПб.: Искусство-СПБ, Набоковский фонд, 1998. 928 с.

Непомнящзй В. С. Лирика Пушкина как духовная биография. Репетиция книги. М.: МГУ, 2001. 238 c. 


\section{References}

Ivanov-Razumnik, P. V. Sochineniia [Works], vol. 5. Petrograd, Tipografiia M. M. Stasiulevicha Publ., 1916. 371 p. (In Russ.)

Kozhevnikov, V. A. Izbrannoe. Stat'i, perevody, kommentarii [Selected Works. Articles, Translations, Comments]. Moscow, St. Petersburg, Nestor-Istoriia Publ., 2017. 431 p. (In Russ.)

Lotman, Iu. M. Roman A. S. Pushkina "Evgenii Onegin". Kommentarii. Posobie dlia uchitelia [Alexander Pushkin's novel "Eugene Onegin". Commentary. Teacher's Manual]. Leningrad, Prosveshchenie Publ., 1983. 416 p. (In Russ.)

Meilakh, B. S. "Evgenii Onegin" ["Eugene Onegin"]. Pushkin. Itogi i problemy izucheniia ["Pushkin. Results and Issues of Studying"]. Moscow, Leningrad, Nauka Publ., 1966. 664 p. (In Russ.)

Nabokov, V. V. Kommentarii k romanu A. S. Pushkina "Evgenii Onegin" [Commentary on the Novel "Eugene Onegin" by Alexander Pushkin]. St. Petersburg, Iskusstvo-SPB Publ., Nabokovskii fond Publ., 1998. 928 p. (In Russ.)

Nepomniashchii, V. S. Lirika Pushkina kak dukhovnaia biografia. Repetitsiia knigi [Pushkin's Lyrics as a Spiritual Biography. Book Rehearsal]. Moscow, MGU Publ., 2001. 238 p. (In Russ.) 


\section{Об авторстве статьи «Поездка в Грузию»}

Аннотация: В статье рассматривается анонимная статья «Поездка в Грузию», напечатанная в «Московском Телеграфе» за 1833 г., и устанавливается ее вероятное авторство. В связи с тем, что в специальной литературе «Поездка в Грузию» единодушно получила статус «шовинистической статьи», исследователи долгое время не поднимали проблему авторства этого текста. В публикуемой статье уделяется внимание работе «Замечания на статью “Путешествие в Грузию”, помещенную когда-то в одном из московских журналов», ошибочно приписываемой Марлинскому (А. А. Бестужеву), но на самом деле написанной его братом П. А. Бестужевым. Привлекая большое количество писем, заметок, исследований и оставляя в стороне идеологическую часть журнальной полемики, автор вместо традиционного пересказа тех или иных фрагментов из писем и документов предлагает читателю провести эвристическое расследование. В статье все релевантные отрывки сложены в хронологическом порядке, сопровождаются нейтральным информационным комментарием и обрамляются научными выводами. В итоге автор приходит к выводу, что статья «Поездка в Грузию» может быть атрибутирована П. П. Каменскому.

Ключевые слова: А. А. Бестужев (Марлинский), П. А. Бестужев, П. П. Каменский, автор, проблема авторства, анонимная статья, Кавказ, Владикавказ, Грузия.

Информация об авторе: Виталий Иванович Симанков, доктор филологических наук (PhD), независимый исследователь, г. Харьков, Украина.

E-mail: vitaly.simankov@gmail.com

Дата поступления статьи в редакиию: 21.03 .2021

Дата одобрения статьи рецензентами: 29.05 .2021

Дата публикации статьи: 30.09.2021

Для цичтирования: Симанков В. И. Об авторстве статьи «Поездка в Грузию» // Два века русской классики. 2021. Т. 3, № 3. С. 124-141. https://doi.org/10.22455/26867494-2021-3-3-124-141 


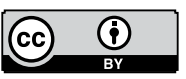

This is an open access article distributed under the Creative Commons Attribution 4.0 International (CC BY 4.0)
Dva veka russkoi klassiki,

vol. 3, no. 3, 2021, pp. 124-141. ISSN 2686-7494

Two centuries of the Russian classics, vol. 3, no. 3, 2021, pp. 124-141. ISSN 2686-7494

Research Article

(C) 2021. Vitaliy I. Simankov Independent Researcher Kharkov, Ukraine

\title{
Upon the Authorship of “Travel to Georgia”
}

\begin{abstract}
The present paper deals with the "Travel to Georgia", an anonymous article published in the "Moscow Telegraph" for 1833, and speculates upon its probable authorship. "Travel to Georgia" was unanimously perceived as a "chauvinistic article", and the problem of its authorship has been left out of consideration. The paper also deals with the "Remarks on the 'Travel to Georgia, an article lately published in one of the Moscow magazines", erroneously attributed to Marlinsky (A. A. Bestuzhev). Drawing on a number of letters and other documentary sources, the author makes it possible for the reader to conduct his or her own private investigation. All relevant extracts and fragments in the article are chronologically arranged and provided with non-judgmental commentary. The study makes it possible to conclude that "Travel to Georgia" may be attributed to Pavel Kamensky.

Keywords: A. A. Bestuzhev (Marlinsky), P. A. Bestuzhev, P. P. Kamensky, author, problem of authorship, anonymous article, Caucasus, Vladikavkaz, Georgia.
\end{abstract}

Information about the author: Vitaliy I. Simankov, $\mathrm{PhD}$, independent researcher, Kharkov, Ukraine.

E-mail: vitaly.simankov@gmail.com

Received: March 21, 2021

Approved after reviewing: May 29, 2021

Published: September 30, 2021

For citation: Simankov, V. I. "Upon the Authorship of 'Travel to Georgia." Dva veka russkoi klassiki, vol. 3, no. 3, 2021, pp. 124-141. (In Russ.) https://doi.org/10.22455/26867494-2021-3-3-124-141 
Сто лет назад М. П. Алексеев обратил внимание на статью, опубликованную в «Сыне Отечества» 1838 г. за подписью «Марлинский» [Марлинский], и оставил следующее примечание: «Эта статья по недоразумению не попала в полное собрание его сочинений, если не ее имеет в виду Николай Бестужев в письме от 7 марта 1838 г. (см. ниже. - В. С.); в последнем случае она принадлежит не Марлинскому, именем которого подписана, но его брату - Павлу Александровичу» [Алексеев: 143]. Статья действительно принадлежала не Марлинскому, но Павлу Бестужеву. В 1950-е гг. «Замечания на статью "Путешествие в Грузию", помещенную когда-то в одном из московских журналов» попали в поле зрения Наби Джусоева и Вано Шадури, которые установили скрытый объект полемики [Виноградов 1966: 63-82]. Им оказалась анонимная статья под названием «Поездка в Грузию», напечатанная в «Московском Телеграфе» за 1833 г. [Поездка в Грузию]. Если вопрос с авторством «Замечаний» удалось разрешить, то вопрос с авторством «Поездки в Грузию» так и остался загадкой.

Дело, впрочем, осложнялось еще и тем, что в специальной литературе «Поездка в Грузию» единодушно получила статус «шовинистической статьи» [Виноградов 1981]. Между тем сохранились письма А. Бестужева (Марлинского), который в целом сочувственно отнесся к самой статье, отметив незаурядный талант автора, однако письма эти, как правило, игнорируются. Задача настоящей статьи установить авторство анонимной «Поездки в Грузию», оставляя за скобками идеологическую часть журнальной полемики.

Вместо традиционного пересказа тех или иных фрагментов из помещаемых ниже писем мы решили избрать иной путь: сложить все релевантные отрывки в хронологическом порядке, сопроводив их нейтральным информационным комментарием. Такой способ распо- 
ложения материала позволит читателю самому провести собственное эвристическое расследование.

\section{$\underline{1833-1834 \text { гг. }}$}

23 ноября 1833 г. Дербент. А. Бестужев (Марлинский) - Кс. ПолеBomy:

«Получил я тринадцатый номер “Телеграфа” и с наслаждением прочел главу Гюго...» [Бартенев: 8].

В 1833 г. из-за цензурных проволочек некоторые номера «Московского Телеграфа» выходили с заметным опозданием. Так, июльский («тринадцатый») номер «Московского Телеграфа» вышел в начале октября (ц. р. 25 сентября 1833 г.). Для сравнения: № 15 (Август) - ц. р. 20 ноября 1833 г.; № 16 (Август) — ц. р. 10 декабря 1833 г.

1833 г., начало декабря. Выход в свет анонимной «Поездки в Гру3ию».

Статья состоит из двух частей: 1. «Дорога до Владикавказа»; 2. «Переезд через Кавказ».

25 января 1834 г. А. Бестужев (Марлинский) - Кс. Полевому:

«Получил 15 № “Телеграфа”. <...> Не знаю, кто писал “Дорогу во Владикавказ” («Поездку в Грузию». - B. C.), - и хоть я совершенно согласен с ним, что горцев одно средство усмирить - это их вырезать до одного, но так жестоко бранить их за разбой - несправедливо очень. Как хотеть, чтоб они бросили ремесло, которым живут от сотворения Кавказа, - и в какое ж время? когда русские, как удав, с каждым днем уже и тесней стягивают кольца свои и отнимают у них поле за полем, утес за утесом. Их укоряют в неблагодарности, - но, ради Магомета, скажите, за что им быть благодарными? Или в самом деле, наши картечи и штыки такое благодеяние, что век не оплатить за него поклонами? Вспомните об их мстительных обычаях, вспомните об их вере, позволяющей со врагом всякое коварство и, всего более, посудите, как они невежественны. Без 
всякого сомнения, думать, будто бы торговля или просвещение смягчит их нравы, смешно и безрассудно; это совет мышей, присуждающих коту орден колокольчика на шею; но если мы слабы и полумерны в своей политике с горцами, не будем, по крайней мере, несправедливы, обвиняя их. Дома они имеют множество доблестей, давно затерянных устроенными народами, и разбой в их понятиях не только не бесчестен, но славен и, что всего важнее, необходим: он составляет часть их домашней экономии. Русские еще возвысили их разбой на степень войны, чего прежде они не видали от века, и придали частным удальствам и кровомщениям характер народности, совокупности. Вольно ж было нам трактовать с шайками висельников, как с народами, и уважать, как посланников, оборванцев, которых не послушают в их селении три курицы. А спросите вы еще: сколько миллионов раздаем мы ежегодно в пенсии и подарки старшинам и ханам, которые при первой встрече заплатят за них пулями? Спросите вы еще: каким людям раздаются они, мимо имеющих истинное влияние на этих своевольников? Итог будет долог, а комментарий бесконечен. И что ж мы выиграли? То разве, что дороги, которые были открыты со времен Петра, теперь непроездны, и что мы не ходим гулять под стенами городов без пушек. Признаться, стоило для этого выкармливать сорок лет горных орлов своим мясом и прудить кавказские реки сибирским серебром!.. Правда, в Россию вывозят отсюда дрянной шелк, кислое вино, подмешанный шафран и крап для карточной фабрики, - но разве всего этого не возили прежде, искони, и во сто крат более, и в тысячу раз лучше? - Ну, право, если бы оценить в тысячу каждую солдатскую голову и счесть все деньги, истраченные на Кавказ, то мы могли бы вылить свой Кавказ из меди на Пулковской горе. Вот уж, что называется: “из короба не лезем, в коробе не едем и короба не отдаем!” Если бы мы взялись за ум, да истратили бы в один поход то же число солдат, что тратим в два года от поносов и лихорадок, да завладели бы разом здоровым климатом гор, выгнав вон горцев, вон с лица Азии, или с лица земли (уж валять, так валять, а то половинное насилие никуда не годится), - так тогда можно бы сделать из Кавказа, если не рай, то райчик, а то мы платим кровью за то, что мы любуемся на этот раек издали, и толкуем о торговле, отправляя дюжину телег в Тифлис, да гноя один пароходишко в Астрахани. Антипод статьи: “Дорога в Грузию” («Поездка в Грузию». - В. С.) - поэма Полежаева “Эрпели”...» [Долгов: 831-833]. 
3 февраля 1834 г. А. Бестужев (Марлинский) - Павлу Бестужеву:

«Не Каменский ли писал в “Телеграф” о Гори? Это очень недурно для новичка» [Семевский: 340].

Имеется в виду статья под названием «Гори, древняя столица Карталинии», которая была подписана автором следующим образом: «Гори, 25 июля. Херсонец» [Херсонец]. Принадлежность П. П. Каменскому этой и последующей публикации («Татарская легенда об Искан-

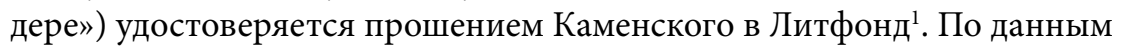
А. Ильина-Томича, 4 августа 1832 г. П. Каменский «вступил унтерофицером в Эриванский карабинерский полк, из коего переведен 8 мая 1833 г. в Херсонский гренадерский полк, а с 1 июня 1834 г. находился в Грузинском гренадерском полку, побывав в нескольких экспедициях против горцев» [Ильин-Томич: 328]. Очевидно, что псевдоним «Херсонец» объясняется службой Каменского в Херсонском гренадерском полку.

Фраза «Это очень недурно для новичка» содержит в себе не только оценочное суждение - она показывает осведомленность А. Бестужева в биографии самого П. П. Каменского. Иными словами, откуда бы Бестужев мог знать о том, что публикации Каменского в «Московском Телеграфе» - это его дебют?

$<$ Начало 1834 г.> Ф. Ф. Торнау. «Воспоминания о Кавказе и Грузии»:

«На Эриванской площади (в Тифлисе. - В. С.) жили еще: адъютант Языков, умерший в помешательстве, Павел Бестужев и Каменский с молодым красивым кумыкским князем Мусса-Хасаем, которого они взялись воспитывать на европейский лад...» [Торнау: 700].

«Воспоминания» Ф. Ф. Торнау - единственный источник, свидетельствующий о личном знакомстве Павла Каменского с Павлом Бестужевым. Сюжет о воспитании кумыкского князя нашел отражение в автобиографическом романе П. Каменского «Искатель сильных ощущений» (1839) - здесь Мусса-Хасай выведен в облике молодого тата-

${ }^{1}$ Прошение П. Каменского: РНБ. Ф. 438. № 15. Л. 223 [Рейтблат: 459]. 
рина Мурата, живущего на воспитании у Павла Энского (т. е. Павла Каменского).

15 февраля 1834 г. А. Бестужев (Марлинский) - Павлу Бестужеву:

«У меня гостит Яков Иванович (Костенецкий. - B. С.), который тебе кланяется» [Семевский: 340].

<Февраль 1834 г.> Я. И. Костенецкий. «Из воспоминаний»:

«Однажды Бестужев, лежа против меня на кровати и читая “Библиотеку для чтения”, вдруг спросил, не знаю ли я, кто это такой П. Каменский, которого статью он только что прочитал в журнале и которая ему очень понравилась. А как Павел Каменский был моим товарищем по университету и тогда находился тоже на Кавказе, то я и рассказал ему всё, что знал об этом довольно талантливом писателе своего времени» [Костенецкий: 448].

Костенецкий дважды встречался с Бестужевым: в июне 1833 г. и в феврале 1834 г. Описываемый эпизод, очевидно, относится к февралю 1834 г. - соответственно в эту пору Бестужев мог прочесть только анонимные статьи Каменского в «Московском Телеграфе» (1833); в «Библиотеке для Чтения» статей Каменского в указанный период еще не было (примечательно, что все комментаторы обходят этот фрагмент стороной).

8 марта 1834 г. А. Бестужев (Марлинский) - Павлу Бестужеву:

«Пожалуйста, не горячись и не пиши к ... Презрение - лучший ответ на дерзости. Притом мы не знаем всего хорошенько et ça aura l'air d’une bravade» [Семевский: 342].

Публикатор письма (М. И. Семевский) намеренно выпустил здесь чье-то имя (Каменского?), ибо речь шла о еще живом человеке.

10 марта 1834 г. Павел Бестужев завершает свои «Замечания» на «Поездку в Грузию».

Обратим внимание на дату под журнальной публикацией: Замечания на статью «Путешествие в Грузию», помещенную когда-то 
в одном из московских журналов / Тифлис, 10 марта. Марлинский [= Павел Бестужев] // Сын Отечества. 1838. T. I. № 1. Отд. IV. С. 1-15. Указание «Тифлис, 10 марта» может означать только одно: «Замечания», являющиеся откликом на «Поездку в Грузию», были написаны Павлом Бестужевым в Тифлисе в феврале - марте 1834 г. Напомним, что Павел Бестужев служил на Кавказе до 1835 г., а затем вышел в отставку и вернулся в Петербург, где сделался негласным редактором «Журнала для чтения воспитанников военно-учебных заведений». По словам И. Л. Андроникова, «в год смерти Пушкина он помещает на страницах этого органа (1837. Т. V. № 17. - В. С.) отрывок из пушкинского “Путешествия в Арзрум”» [Андроников: 226].

22 марта 1834 г. (получено - 2 апреля 1834 г.). А. Бестужев (Марлинский) - Павлу Бестужеву:

«Любезный Поль. Критику твою прочел. Нет в ней общности и ты привязываешься к пустякам: надо было главное смотреть на дух, не на слог. Я исправил, что успел, и послал с этою почтою в Тифлис» [Семевский: 343].

22 марта 1834 г. Дербент. А. Бестужев (Марлинский) - Кс. Полевому:

«Посылаю статью моего брата Павла; это первая попытка человека, который никогда еще не писал, но думал иногда очень порядочно. Напечатайте, если найдете достойным. Это даже нужно, ибо возражение справедливо. Я кое-что поправил - доправьте» [Полевой: 455].

Конец марта 1834 г. Обрывок потерянного письма с примечанием Кс. Полевого:

«(При посылке статьи брата его Павла Александровича, которая уже не могла быть напечатана в М. Телеграфе, прекращенном в начале апреля 1834 г.) К. А.» [Полевой: 455].

3 мая 1834 г. Тифлис. А. Бестужев (Марлинский) - Кс. Полевому: 
«Предпоследнее письмо ваше получил я в дороге, и оно очень меня порадовало, - точно я друга встретил в пустыне; но последнее, с вестью о кончине “Телеграфа”, весьма огорчило меня, еще более как русского, нежели как вашего друга, почтенный Ксенофонт Алексеевич!» [Полевой: 455].

31 мая 1834 г. Ахалцых. А. Бестужев (Марлинский) - Кс. Полевомy:

«Вероятно, вы будете читать ущелие Борджомское в двух копиях, ибо я встретился там с описателем Гори, который обещает быть недурным писателем» [Полевой: 459].

Настоящее письмо - единственный источник, свидетельствующий о встрече Павла Каменского с Бестужевым. К такому же выводу приходит Ф. З. Канунова [Бестужев-Марлинский: 697]. Говоря о двух копиях, Бестужев (Марлинский), должно быть, имеет в виду, что и Каменский, «описатель Гори», и сам Бестужев думали написать очерки про Боржомское ущелье. Соответствующий очерк Каменского - при вероятном посредничестве Н. Полевого - появился впоследствии в «Телескопе» [Каменский 1836], а чуть позднее и в «Повестях и рассказах» П. Каменского [Каменский 1838] ${ }^{1}$. Примечательно, что автором единственной печатной заметки, написанной на смерть Бестужева (Марлинского), был П. П. Каменский [Рейтблат: 459].

31 мая 1834 г. Ахалцых. А. Бестужев (Марлинский) - Павлу Бестужеву:

«Любезный Поль. Я выехал, кажется, 22 мая, и 24 прибыл в Ахалцых. Судьба хоть грозила изломать мне ноги, заставив ехать по чертовской дороге (ибо нижняя смыта, а мосты сорваны), зато потешило глаза Барджомское Ущелье: точно прелесть и необыкновенно схоже с берегами Лены» [Семевский: 343-344].

1 Следует заметить, что роман П. Каменского «Искатель сильных ощущений» (1839) публиковался сначала отдельными главками в различных периодических изданиях и альманахах. См., например: [Каменский 1838]. 
25 июля 1834 г. А. Бестужев (Марлинский) - Павлу Бестужеву:

«Твою статью желает Полевой послать в С. О. («Сын Отечества». B. С.), разрешил я» [Семевский: 345].

27 июля 1834 г. Ахалцых. А. Бестужев (Марлинский) - Кс. Полевомy:

«Статью брата пошлите куда угодно. Только там, где сказано о кресте Андреевой горы, прибавьте: “А теперешний мраморный крест водружен г-м Кохановым, бывшим приставом горских народов, не упомню в котором году"» [Полевой: 461].

Настоящее письмо - еще один источник, позволяющий заключить, что «Замечания» Павла Бестужева на анонимную «Поездку в Грузию» были написаны по свежим следам в феврале - марте 1834 г., хотя опубликованы они были только в 1838 г. Трудно сказать, учел ли Павел Бестужев поправки своего старшего брата в рукописи. Во всяком случае, в печати фрагмент, «где сказано о кресте Андреевой горы» (должно быть: «Крестовой горы»), был изложен иначе:

«Если г. Гамба перекрестил Крестовую гору в mont St. Cristos (= Christophe. - B. C.), то русскому путешественнику стыдно не знать, что Петр I никогда не проходил чрез Кавказские Горы и потому не мог поставить креста на Крестовой Горе, как утверждает г. путешественник. Известно всякому закавказцу, что Петр I ходил на Дербент и Баку, но не чрез горы, а по прибрежью моря, и что крест поставлен каким-то рекрутом Петром Михайловым. То-то, г. путешественник! Слышали мы звон, да не знаем, где он. А кажется, узнать это было очень легко: взобраться только на холм и прочитать надпись» [Марлинский: 13$]^{1}$.

${ }^{1}$ Ср. с текстом в статье «Поездка в Грузию»: 1) «На самой высокой точке переправы чрез Кавказское ущелие - на вершине Крестовой горы императором Петром Великим поставлен крест, в ознаменование перехода его сими местами с войском своим. Отсюда начало названия горы Крестовой. Я желал прочесть надпись, но глубина рыхлого снега, по сторонам от дороги, препятствовала дойти до креста, ибо для сего надлежало еще подняться сажен 50 или более»; 2) «Жалуются на французов, что они искажают иностранные имена, не вслушиваясь в их произношение. 
Павел Бестужев не говорит о том, кто поставил крест на Крестовой горе. Обходит молчанием этот вопрос, кстати сказать, и Пушкин в «Путешествии в Арзрум». По словам же Бестужева (Марлинского), мраморный крест был водружен «г-м Кохановым», однако сведения эти нуждаются по меньшей мере в ономастической коррекции. Сравним данные в анонимной статье «Впечатления и воспоминания покойника» ${ }^{1}$ :

«Крест, поставленный на гранитной пирамиде у дороги, означает высочайшую точку пути через кавказский хребет, и оттого гора называется Крестовою. На мраморной доске вырезана по-русски и по-грузински следующая надпись: “Во славу Божию и в управление генерала от инфантерии Ермолова поставлен приставом горских народов майором Кононовым в 1824 году". По преданию жителей, на этом месте персидский царь Кир распинал непокорных скифов» [Впечатления: 29]².

Вот пример противному: Гамба, в своем "Voyage dans la Russie Méridionale", пожаловал Крестовую гору в Mont St. Cristophe - доказательство, что Гамба имеет уши, не только ухо» [Поездка в Грузию: 363; 361].

${ }^{1}$ Автор «Впечатлений и воспоминаний покойника» до сих пор остается не идентифицированным. Из самого текста следует, что автор так или иначе связан со Ставрополем и не чужд поэзии. Не исключено, что сочинителем «Впечатлений и воспоминаний покойника» был Михаил Павлович Крюков (ок. 1810 - после 1853), младший брат поэта А. П. Крюкова. «Кол. асс. М. П. Крюков» указан как исправляющий должность советника при губернском правлении г. Ставрополя (Кавказский календарь на 1847 год. Тифлис. 1846. Отд. 4. С. 29). Ср. сведения из письма М. П. Крюкова к Ф. В. Булгарину: «В здешнюю сторону (на Кавказ. - В. С.) приехал я еще отроком, и поэтому она сделалась для меня второю родиной. Любовь к ней заставляет меня сообщить вам, для вашей газеты, достоверные известия о том, как мы, ставропольские жители, проводим нынешнее лето, вовсе не занимаясь небывалыми опасностями» [Крюков 1843: 839]. Ср. также «Воспоминания» М. Крюкова о детстве на реке Илек в Оренбургской губернии [Крюков 1850]. Как и старший брат, М. П. Крюков писал стихи. См., например: [Крюков 1828]; с примечанием издателя: «Брат А. П. Крюкова, известного любителям словесности прекрасными стихотворениями, помещаемыми в “Вестнике Европы”, в “Сыне Отечества", в “Сев. Пчеле” и в других журналах. - Рзмхин.». Подробнее о братьях Крюковых см.: [Вацуро].

${ }^{2}$ Сведения эти, похоже, перекочевали впоследствии в работу В. А. Потто «Кавказская война»: «Ермолов возобновил этот крест в память сооружения Военно-Грузинской дороги. И теперь любопытный путешествен- 
Сравним также данные Осипа Константинова в «Кавказском календаре на 1851 год»: «[Крест] поставлен русскими, при разработке военно-грузинской дороги, приставом горских народов, подполковником Канановым» [Константинов: 68]. Нетрудно заметить, что в трех источниках - три разных имени: Коханов, Кононов и Кананов. Какой вариант ближе к истине? Скорее всего, последний. Фамилия подполковника Кананова, управлявшего горскими народами (мтиульцами), фигурирует в рапорте статского советника Завилейского графу Паскевичу от 2 февраля 1830 г. [Антелава: 312]. Под «майором Канановым» в 1824 г. и «подполковником Канановым» в 1830 г., вероятнее всего, скрывается Давыд Кананов, биографические сведения о котором довольно скудны. Следует отметить, что сведения о водружении креста на Крестовой горе вообще противоречивы [Маркелов]. Не исключено, что прав был Денис Давыдов, отметивший в описании своей поездки в 1826 г. из Москвы в Тифлис следующую деталь:

«Крестовая гора получила название от креста, водруженного на ней первыми русскими, перешедшими за Кавказ, в Грузию во время Екатерины, но крест был деревянный и уже обветшал; теперь генерал Ермолов соорудил огромный, высеченный из гранита крест, с таким же подножием» [Давыдов: 16].

По мнению Б. М. Эйхенбаума, в повести М. Ю. Лермонтова «Бэла» содержится прямая ссылка на приведенный выше фрагмент из «Замечаний» (1838) Павла Бестужева, а это будто бы указывает на то, что «Бэла» «была написана не раньше начала 1838 г.» [Эйхенбаум: 270]. Вероятность указанной ссылки, на наш взгляд, стремится к нулю, соответственно, и датировка написания «Бэлы» представляется произвольной: если у Лермонтова и есть заимствования из чужой статьи, то статья «Поездка в Грузию» представляется более вероятным кандидатом.

Фрагмент из процитированного выше письма А. Бестужева («Статью брата пошли куда угодно...») натолкнул Л. А. Лебедеву на следу-

ник прочтет на мраморной доске, врезанной в его гранитный пьедестал, следующую надпись: “Во славу Божию, в управление генерал от инфантерии Ермолова, поставлен приставом горских народов майором Кононовым в 1824 году"» [Потто: 98]. 
ющий вывод: «Ксенофонт Полевой исполнил просьбу Александра Марлинского, но по какой-то непонятной причине (может быть, по сознательному расчету, так как имя Марлинского было весьма популярным) статья была напечатана в первой книге “Сына Отечества" за 1838 г. с подписью - Марлинский, что вызвало оживленный обмен письмами братьев» [Лебедева: 99]. Вывод о том, что «Ксенофонт Полевой исполнил просьбу Александра Марлинского», оказался бы состоятелен, если бы между написанием «Замечаний» Павла Бестужева и их публикацией был бы зазор в несколько месяцев. Между тем зазор этот составляет четыре года! Остается открытым вопрос: что заставило Павла Бестужева опубликовать свои полемические замечания на статью из «Московского Телеграфа» четырехлетней давности?

\section{$\underline{1838}$}

Январь 1838 г. Петровский завод. Павел Бестужев публикует «Замечания на статью "Путешествие в Грузию", помещенную когда-то в одном из московских журналов».

7 марта 1838 г. Петровский завод. Николай Бестужев - Павлу Бестужеву (рукой М. К. Юшневской):

«Благодарим тебя за литературные новости. В самом деле для нас была новость, что Полевой - редактор “Пчелы” и “С. Отечества”, давно бы пора, не в укор Гречу и Булгарину, издавать их попорядочнее; надежда теперь есть. Полевой в Петербурге, конечно, не уступит тому Полевому, который был в Москве. Последнее время “С. Отечества” был так дурен, что мы его здесь не получали и потому не знаем твоей статьи, вышедшей под именем Марлинского» [Троцкий: 369].

В 1838 г. официальными редакторами «Северной Пчелы» и «Сына Отечества» были Ф. В. Булгарин и Н. И. Греч соответственно, негласным же редактором обоих изданий был Н. А. Полевой. Сохранились ли письма П. Бестужева к Н. Бестужеву с «литературными новостями» за январь - февраль 1838 г. - неизвестно. 
После 7 марта 1838 г. Петровский завод. Николай Бестужев - Павлу Бестужеву:

«Мы читали твою статейку в “Сыне отечества” под названием Марлинского и были очень ею довольны. Правда, что есть некоторое сходство со слогом покойного Александра, особенно когда ты брызжешь так называемыми во время оно Бестужевскими каплями; но видно, что твой слог примет направление более сериезное и что в твоем будет более правильного хода мыслей, нежели у него» [Лебедева: 99].

Итак, в «Московском Телеграфе» за 1833 г. в двух соседних номерах появились две анонимные статьи с кавказской тематикой: «Поездка в Грузию» и «Гори, древняя столица Карталинии».

Достоверно известно, что последняя статья принадлежит П. П. Каменскому. Приведенный выше материал из писем А. А. Бестужева позволяет предположить, что и автором первой статьи, а именно «Поездки в Грузию», был всё тот же П. П. Каменский. Отметим здесь еще одно примечательное схождение. В статье «Поездка в Грузию» анонимный автор сделал следующее примечание к топониму «Владикавказ»: «Жители и солдаты называют его просто: Капкай» [Поездка в Грузию: 348]. А в романе «Искатель сильных ощущений» П. П. Каменский оставил идентичное примечание к топониму «Капкай»: «Так называют солдаты и казаки Владыкавказ» [Каменский 1839: 3]. Заметим также, что название «Капкай» как дублет Владикавказа крайне редко встречается в русской литературе 1820-1830-х гг. Чуть ли не единственный пример (помимо уже перечисленных случаев) - это пушкинское «Путешествие в Арзрум»: «Мы достигли Владикавказа, прежнего Кап-кая, преддверия гор. Он окружен осетинскими аулами...» [Пушкин: 27]; и запись в пушкинском дневнике: «Кап Кой». Обратимся к комментарию осетинского историка Г. И. Кусова: «Почему поэт назвал Владикавказ Капкаем или Капкоем, остается до сих пор загадкой. Правда, в документах военных канцелярий и литературе порой появлялось это таинственное слово. Притом сообщалось, что Владикавказ назывался капкайским постом по имени расположенного близ него осетинского аула Капкай. Но аула с таким названием никогда не существовало не только у Владикавказа, но и на всей территории Северного Кавказа. Уже позднее дореволюционный кавказовед К. Ф. Ган сумел установить лишь то, что черкесское назва- 
ние Капкай есть, без сомнения, сокращенное турецкое Капукая = ворота-скала, то есть скалы, образующие (на юге от города) ворота» [Кусов: 78]. Недоумение осетинского историка, на наш взгляд, только усиливает нетривиальный параллелизм в использовании названия Капкай между «Поездкой в Грузию» (1833) и «Искателем сильных ощущений» (1839)․․

${ }^{1}$ По устному сообщению К. П. Юдина, между анонимной статьей «Поездка в Грузию» и романом П. П. Каменского «Искатель сильных ощущений» можно отыскать параллелизм и в характерной контекстуализации живописца Сальватора Розы (в «Поездке в Грузию» он назван просто «Сальватором»). В обоих случаях имя итальянского художника включено в рассуждения о способности/неспособности литературы и живописи передать кавказские пейзажи. См.: [Поездка в Грузию: 353]; [Каменский 1839: 193]. Подробнее об отсылках к живописи Сальватора Розы в русской питературе первой половины XIX в. см.: [Долинин: 135-143]. 


\section{Список литературы \\ Источники}

Бартенев П. И. Письмо А. А. Бестужева (Марлинского) к К. А. Полевому [23 ноября 1833 г.] // Русский Архив. 1874. Кн. 2. № 7. Стб. 6-10.

Бестужев-Марлинский А. А. Кавказские повести / изд. подгот. Ф. З. Канунова. СПб.: Наука, 1995. 703 с.

Впечатления и воспоминания покойника. Статья первая // Библиотека для Чтения. 1848. T. LXXXVI. № 1 (Январь). Отд. III. С. 1-58.

Давыдов Д. В. Записки покойного Дениса Васильевича Давыдова во время поездки его в 1826 году из Москвы в Тифлис // Русская Беседа. Собрание сочинений русских литераторов, издаваемых в пользу А. Ф. Смирдина. СПб.: Тип. Имп. Акад. наук, 1842. T. II. С. 1-30.

Долгов С. О. Письма А. А. Бестужева (Марлинского) к братьям Полевым [1832-1834 гг.] // Русское Обозрение. 1894. Т. ХХІХ. № 10 (Октябрь). С. 819-834.

Кам. [Каменский П. П.] Сплавщики по Куре. Отрывок из романа // Телескоп. 1836. Ч. XXXIV. № 13. С. 38-62.

Каменский П. П. Боржом. (Еще отрывок из романа) // Повести и рассказы П. Каменского. СПб.: Тип. ІІІ. Отд. Собств. Е. И. В. Канцел., 1838. Ч. 2. С. 135-167.

Каменский П. П. Отрывок из романа «Энский» (Глава II, первой части) // Сборник на 1838 год. СПб.: Тип. Воейкова и Комп., 1838. С. 215-231.

Каменский П. П. Искатель сильных ощущений: В 3 ч. СПб.: Тип. А. Смирдина, 1839. Ч. 1.310 c.

Константинов О. От Дарьяла до Тифлиса // Кавказский календарь на 1851 год. Тифлис, 1850. Отд. 3. С. 65-89.

Костенецкий Я. И. Александр Александрович Бестужев (Марлинский). (Из воспоминаний Я. И. Костенецкого) // Русская Старина. 1900. T. CIV. № 11 (Ноябрь). C. 441-457.

Крюков М. П. Надгробие Кудряшеву (Мая 11, 1827) («Под сею насыпью простою...») // Вестник Европы. 1828. № 21 (Ноябрь). С. 28.

Крюков М. П. Кавказское житье-бытье. (Письмо к Ф. В. Б. [= Ф. В. Булгарину]) // Северная Пчела. 1843. № 210 (21 сентября). С. 839-840.

Крюков М. П. Воспоминания // Ставропольские губернские ведомости. 1850. № 38. С. 476-477.

Лебедева Л. А. Письмо Павла Бестужева к А. Бестужеву (Марлинскому) о смерти Пушкина // Декабристы и их время. М.; Л.: Академия наук СССР, 1951. С. 97-100.

Марлинский [Бестужев П. А.]. Замечания на статью «Путешествие в Грузию», помещенную когда-то в одном из Московских журналов // Сын Отечества. 1838. T. 1. № 1 (Январь). Отд. IV. С. 1-15.

Поездка в Грузию // Московский Телеграф. 1833. Ч. LII. № 15. Август (ц. р. 20 ноября 1833). С. 327-367.

Полевой Кс. А. Письма Александра Александровича Бестужева к Н. А. и К. А. Полевым, писанные в 1831-1837 годах // Русский Вестник. 1861. Т. XXXII. № 4 (Апрель). С. 425-487. 
Потто В. А. Кавказская война в отдельных очерках, эпизодах, легендах и биографиях. СПб.: Тип. Окружного Штаба Кавказского военного округа, 1889. Т. 5. $320 \mathrm{c}$.

Пушкин А. С. Путешествие в Арзрум во время похода 1829 года // Современник. 1836. Т. 1. С. 17-84.

Семевский М. И. Александр Александрович Бестужев (Марлинский) [Письма, 1833-1835] // Отечественные Записки. 1860. Т. СХХХ. № 6 (Июнь). Отд. 1. C. $299-348$.

Т. [Торнау Ф. Ф.] Воспоминания о Кавказе и Грузии // Русский Вестник. 1869. T. LXXX. № 4 (Апрель). С. 658-707.

Троцкий И. М. Письма Н. А. и М. А. Бестужевых с Петровского завода // Бунт декабристов: Юбилейный сборник. Л.: Былое, 1926. С. 359-371.

Херсонец. Гори, древняя столица Карталинии // Московский Телеграф. 1833. Ч. LII. № 16. Август (ц.р. 10 декабря 1833). С. 493-512.

\section{Исследования}

Алексеев М. П. Этюды о Марлинском // Сборник трудов Иркутского государственного университета. Иркутск, 1928. Т. 15. С. 113-174.

Андроников И. Л. Тетрадь Василия Завелейского // Прометей. М.: Молодая гвардия, 1968. Вып. 5. С. 206-231.

Антелава И. Г. Государственные крестьяне Грузии в XIX веке. Тбилиси: Сабчота Сакартвело, 1969. Т. 1. 483 с.

Вацуро В. Э. Александр Крюков и его стихи // Прометей. М.: Молодая гвардия, 1987. Вып. 14. С. 252-261.

Виноградов Б. С. Бестужев П. А. // Лермонтовская энциклопедия / гл. ред. В. А. Мануйлов. М.: Сов. энциклопедия, 1981. С. 58.

Виноградов Б. С. Кавказ в русской литературе 30-х годов XIX века. Грозный: Чечено-ингушское книжное изд-во, 1966. 184 с.

Долинин А. А. Два комментария к «Путешествию в Арзрум» // Временник Пушкинской комиссии. СПб.: Росток, 2020. Вып. 34. С. 130-143.

Ильин-Томич А. А. Переписка В. И. Даля и М. П. Погодина // Лица: Биографический альманах. М.; СПб.: Феникс, Atheneum, 1993. Вып. 2. С. 287-388.

Кусов Г. И. Малоизвестные страницы кавказского путешествия А. С. Пушкина. Орджоникидзе: Ир, 1987. 222 с.

Маркелов Н. В. Крест над Кавказом // Московский журнал. 2000. № 3. С. 23-25.

Рейтблат А. И. Каменский П. П. // Русские писатели, 1800-1917: Биографический словарь. М.: Большая российская энциклопедия, 1992. Т. 2. С. 459-460.

Эйхенбаум Б. М. Статьи о Лермонтове. М.; Л.: Академия наук СССР, 1961. 372 с. 


\section{References}

Alekseev, M. P. "Etiudy o Marlinskom" ["Essays on Marlinsky"]. Sbornik trudov Irkutskogo gosudarstvennogo universiteta [Irkutsk State University Studies], vol. 15. Irkutsk, 1928, pp. 113-174. (In Russ.)

Andronikov, I. L. “Tetrad' Vasiliia Zaveleiskogo" ["Vasily Zaveleisky Notebook”]. Prometei [Prometheus], issue 5. Moscow, Molodaia gvardiia Publ., 1968, pp. 206-231. (In Russ.)

Antelava, I. G. Gosudarstvennye krest'iane Gruzii v XIX veke [The State-Owned Peasants in 19-century Georgia], vol. 1. Tbilisi: Sabchota Sakartvelo Publ., 1969. 483 p. (In Russ).

Vatsuro, V. E. “Aleksandr Kriukov i ego stikhi” [“Alexander Kriukov and His Poems”]. Prometei [Prometheus], issue 14. Moscow, Molodaia gvardiia Publ., 1987, pp. 252-261. (In Russ).

Vinogradov, B. S. "Bestuzhev P. A." [“Bestuzhev P. A.”] Manuylov, V. A., editor. Lermontovskaia entsiklopediia [Lermontov Encyclopedia. Ed. by V. A. Manuylov]. Moscow, Sovetskaia entsiklopediia Publ., 1981, p. 58. (In Russ).

Vinogradov, B. S. Kavkaz v russkoi literature 30-kh godov XIX veka [The Caucasus as Represented in Russian Literature of the 1830s]. Groznyi, Checheno-ingushskoe knizhnoe izdatel'stvo Publ., 1966. 184 p. (In Russ).

Dolinin, A. A. "Dva kommentariia k 'Puteshestviiu v Arzrum'." ["Two comments on Pushkin's 'Journey to Arzrum'.”]. Vremennik Pushkinskoi komissii [Annals of the Pushkin Commission]. Saint-Petersburg, Rostok Publ., 2020. Issue 34, pp. 130-143. (In Russ.)

Il'in-Tomich, A. A. "Perepiska V. I. Dalia i M. P. Pogodina" ["Correspondence of V. I. Dahl and M. P. Pogodin”]. Litsa: Biograficheskii al'manakh [Persons: Biographical almanac], issue 2. Moscow, Saint-Petersburg, Feniks Publ, Atheneum Publ., 1993, pp. 287-388. (In Russ).

Kusov, G. I. Maloizvestnye stranitsy kavkazskogo puteshestviia A. S. Pushkina [Unknown Facts About A. S. Pushkin's Caucasian Travel]. Ordzhonikidze, Ir Publ., 1987. 222 p. (In Russ.)

Markelov, N. V. "Krest nad Kavkazom" ["Cross over the Caucasus"]. Moskovskii zhurnal, no. 3, 2000, pp. 23-25. (In Russ.)

Reitblat, A. I. “Kamenskii P. P.”. Russkie pisateli, 1800-1917: Biograficheskii slovar' [Russian Writers, 1800-1917: Biographical Dictionary], vol. 2. Moscow, Bol'shaia rossiiskaia entsiklopediia Publ., 1992, pp. 459-460. (In Russ).

Eikhenbaum, B. M. Stat'i o Lermontove [Essays on Lermontov]. Moscow, Leningrad, Akad. nauk Publ., 1961. 372 p. (In Russ.) 


\title{
Текстологический комментарий к комедии А. Н. Островского «Богатые невесты»: к вопросу о становлении авторского замысла
}

\author{
Исследование выполнено при финансовой поддержке РФФИ \\ в рамках научного проекта № 19-012-00070A
}

\begin{abstract}
Аннотация: Статья посвящена становлению авторского замысла комедии А. Н. Островского «Богатые невесты». Первоначально пьеса была опубликована в февральском номере «Отечественных записок» за 1876 г., но еще до публикации поставлена в Александринском (Санкт-Петербург) и Малом (Московском) театрах. Комедия вызвала очень противоречивые, а подчас и грубые суждения критиков. В 1876 г. А. Н. Островский, возможно, под влиянием критики, предпринял попытку частично изменить текст пьесы, но далеко не все исправления, сделанные автором, вошли в окончательную редакцию комедии, опубликованную в 1878 г. В отделах рукописей Российской государственной библиотеки и Института русской литературы РАН хранятся черновые автографы пьесы, свидетельствующие о становлении авторского замысла. Описать основные этапы работы над текстом, отслеживая характер основных изменений, в дальнейшем сохраненных или отвергнутых драматургом, основная задача представленной работы.
\end{abstract}

Ключевье слова: А. Н. Островский, комедия «Богатые невесты», черновые автографы, цензурная писарская копия, редакции, авторские коррективы, авторский замысел, образ героя, действующие лица, персонажи, драматический сюжет, конфликт.

Информация об авторе: Елена Николаевна Белякова, кандидат филологических наук, доцент, заведующая кафедрой медиакоммуникаций и туризма, Костромской государственный университет, ул. Дзержинского, д. 17, 156000 г. Кострома, Россия.

E-mail: helenbel31@yandex.ru

Дата поступления статьи в редакиию: 17.05 .2021

Дата одобрения статьи рецензентами: 04.07 .2021

Дата публикации статьи: 30.09.2021

Для цитирования: Белякова Е. Н. Текстологический комментарий к комедии А. Н. Островского «Богатые невесты»: к вопросу о становлении авторского замысла // Два века русской классики. 2021. Т. 3, № 3. С. 142-159. https://doi.org/10.22455/2686-7494-2021-3-3-142-159 


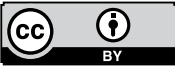

This is an open access article distributed under the Creative Commons Attribution 4.0 International (CC BY 4.0)
Dva veka russkoi klassiki,

vol. 3, no. 3, 2021, pp. 142-159. ISSN 2686-7494

Two centuries of the Russian classics, vol. 3, no. 3, 2021, pp. 142-159. ISSN 2686-7494

Research Article

(c) 2021. Elena N. Belyakova

Kostroma State University

Kostroma, Russia

\section{Textological Commentary to A. N. Ostrovsky's Comedy Rich Brides: on the Formation of the Author's Intention}

Acknowledgments: The reported study was funded by Russian Foundation for Basic Research (RFBR), project number 19-012-00070A.

Abstract: The article is devoted to the formation of the author's intention in A. N. Ostrovsky's comedy Rich Brides. The play was originally published in 1876 in the February issue of Otechestvennye Zapiski, but before publication it had been staged at the Alexandrinsky (St. Petersburg) and Maly (Moscow) theaters. The comedy provoked very contradictory, and sometimes rude, judgments from critics. In 1876, A. N. Ostrovsky, possibly under the influence of criticism, attempted to partially change the text of the play, but not all the author's corrections were included in the final version of the comedy, published in 1878. Manuscript departments of the Russian State Library and the Institute of Russian Literature preserve draft autographs of the play, testifying to the formation of the author's intention. To describe the main stages of work on the text, tracing the nature of the main changes, later saved or rejected by the playwright, is the main task of the presented work.

Keywords: A. N. Ostrovsky, comedy Rich Brides, draft autographs, censored clerk's copy, editions, author's adjustments, author's intention, hero image, characters, dramatic plot, conflict.

Information about the author: Elena N. Belyakova, $\mathrm{PhD}$ in Philology, Assistant Professor, Head of the Media Communications and Tourism Department, Kostroma State University, Dzerzhinsky St. 17, 156005 Kostroma, Russia.

E-mail: helenbel31@yandex.ru

Received: May 17, 2021

Approved after reviewing: July 19, 2021

Published: September 30, 2021

For citation: Belyakova, E. N. “Textological Commentary to A. N. Ostrovsky's Comedy Rich Brides: on the Formation of the Author's Intention." Dva veka russkoi klassiki, vol. 3, no. 3, 2021, pp. 142-159. (In Russ.) https://doi.org/10.22455/2686-7494-2021-3-3-142-159 
Пьеса «Богатые невесты» являет собой пример одного из самых недооцененных произведений драматурга. Ни журнальные критики, ни литературоведы не посвящали ей сколько-нибудь серьезных разборов и не включали комедию в перечень значимых текстов при обзоре творчества А. Н. Островского. Все, что о ней написано, - это преимущественно или комментарии, или короткие статьи справочного характера [Смирнова; Фаркова]. «Возможно, что некоторая сбивчивость жанра этой наскоро написанной пьесы, в которой элементы комические и драматические, сатирические и психологические сочетаются весьма причудливо, и оказалась причиной того, что комедия эта не может быть причислена к лучшим произведениям Островского», писал Е. Г. Холодов [Холодов: 81].

Однако уже первые читатели отмечали, что «Богатые невесты» хоть и занимают вполне скромное место, но стоят в одном ряду с лучшими пьесами 1870 -х гг. и при явной близости европейской (особенно французской) психологической драме, с ее погружением в мир противоречивых любовных коллизий, не только сохраняют национальный колорит, но заключают в себе самостоятельную социально значимую идею. Так, один из критиков XIX в. писал: «По замыслу комедия г. Островского не может быть названа совершенно новою: главный драматический момент ее встречается, между прочим, в комедии Ожье “L'Aventuriêre"... Но разработка Островским основного мотива отличается полною самостоятельностью и принадлежит всецело даровитому автору» [«Богатые невесты» на Александринской сцене: 2]. «Кстати сказать, этот новый “европейский” характер драматургии А. Н. Островского вызывал иногда неоднозначные оценки современной ему критики, которая "не замечая" <..> социальной проблематики пьес, сосредотачивала внимание на определенной зависимости драматических произведений писателя от европейских образцов», - справедливо замечает М. А. Миловзорова [Миловзорова: 44], при этом все так же, лишь мимоходом 
упоминая «Богатых невест» в «числе пьес, в которых можно найти обозначенные (любовные. - E. Б.) коллизии или хотя бы перипетии» [Миловзорова: 48]. А между тем и социальная проблематика, и острота характеров действующих лиц, и любовные перипетии не просто присутствуют в комедии, а представляют собой неразрывное единство в хорошо структурированном художественном тексте, казалось бы, «наскоро» и легко возникшем под пером драматурга.

Действительно, одна из особенностей истории создания комедии «Богатые невесты» - изначальная цельность авторского замысла, позволившая А. Н. Островскому почти без изменений написать полный текст пьесы в предельно короткий срок. В черновом автографе, хранящемся в РГБ, есть записи, свидетельствующие о начале: «Задумана 15 окт<ября> 1875 г. Начата 24 окт<ября> 1875 г.» и конце работы над рукописью: «11-е ноября 1875 г.»‥ Прослеживая характер исправлений, сделанных драматургом в период работы над пьесой, можно сделать вывод, что к моменту написания произведения и драматический сюжет, и конфликт, и характеры действующих лиц присутствовали в его сознании как целостная система.

Так, в перечне действующих лиц почти не произошло изменений. Небольшие коррективы были сделаны драматургом в определении их статуса. Например, Гневышов первоначально был представлен не «действительным статским советником в отставке», а «важной особой», а Пирамидалов - не просто «мелким чиновником», а «мелким чиновником» и «[человеком Белесовой]» ${ }^{2}$. При этом в цензурной писарской копии, хранящейся в Государственной театральной библиотеке (Санкт-Петербург), статус обоих героев уже совпадает с первопечатным текстом. Возможно, работа над пьесой продолжалась Островским в не дошедшем до нас беловом автографе.

Любопытно, что все без исключения действующие лица этой комедии представлены по имени, отчеству и фамилии. По верному замечанию Н. С. Тугариной, у Островского трехсловный, «или полный тип именования, имеют, прежде всего, главы семейств... Обычно это мужчины, но если главой семьи является женщина, например вдова,

${ }^{1}$ Островский А. Н. Бедная невеста. Черновой автограф пьесы // РГБ. Ф. 216. Л. 1, 34.

2 Там же. Л. 1. 
то она именуется так же: Анна Петровна Незабудкина (“Бедная невеста”). Подобный тип именования Островский дает и взрослому самостоятельному человеку: Иван Петрович Бородкин (“Не в свои сани не садись”), Пётр Егорыч Мелузов (“Таланты и поклонники”)» [Тугарина 2010: 233]. В «Богатых невестах» «полный тип именования» имеют и «важный барин», и «девица лет 23-х», и «мелкий чиновник», и вызывающая неизменную улыбку искательница женихов «богатая вдова, купчиха, лет под 40». Но что касается самих имен и возраста героев, то они в черновом автографе те же, что и в первопечатном тексте, т. е. от первоначального замысла до окончательной редакции пьесы не претерпели никаких изменений, что для А. Н. Островского скорее исключение, чем правило.

Однако внутри текста чернового автографа все-таки присутствуют варианты имен героев. Например, Валентина Васильевна Белесова местами упоминается как Валентина Юрьевна ${ }^{1}$, а Анна Афанасьевна Цыплунова как Глафира Афанасьевна². Можно предположить, что возникающий вариант отчества Белесовой «Юрьевна», везде исправленный драматургом на «Васильевна», объясняется произвольной или, скорее, непроизвольной авторской ассоциацией, связывавшей ее образ с образом Лидии Юрьевны Чебоксаровой («Бешеные деньги»). Обе героини являли собой новый для русской литературы тип «испорченной» женщины, «порочной» красавицы и заявляли «небывалую» для русской литературы тему: «искупление падшей женщины посредством любви» [M, В.: 1]. При этом сам факт авторского исправления отчества с «Юрьевны» на «Васильевну» свидетельствует о сознательном отказе драматурга от проведения ненужной аналогии между этими героинями. Более того, отчество «Юрьевна» указывало бы на дополнительную контекстуальную связь образов Белесовой и Юрия Цыплунова, подчеркивать которую, вероятно, не входило в намерение Островского.

Имя «Глафира» в отношении матери Цыплунова возникло, возможно, совершенно случайно, поскольку героиня с таким именем (Глафира Алексеевна) представлена в пьесе «Волки и овцы», написанной незадолго до «Богатых невест» и подготовленной к первой театральной по-

\footnotetext{
1 Там же. Л. 2, 4, 4 об.

2 Там же. Л. 5 об.
} 
становке в декабре 1875 г. Можно сказать, что работа над «Богатыми невестами» и «Волками и овцами» шла параллельно, и имена всех действующих лиц присутствовали в активной памяти драматурга. Так что написание одного имени вместо другого могло быть вызвано механической ошибкой автора.

Куда более явная связь изначально прослеживалась между Цыплуновой и другой матерью взрослого сына, Ариной Егоровной Хорьковой, персонажем комедии «Бедная невеста». Приведем для примера два фрагмента диалогов матери и сына из черновых автографов «Бедной невесты» и «Богатых невест», указывающие на изначально предполагавшуюся близость житейских ситуаций и характеров героев этих пьес. Вот Хорькова сообщает Незабудкиной о разговоре с сыном: «Прихожу домой, говорю: - Миша! Не хочешь ли, друг мой, жениться; мне, говорю, от богатых невест отбою нет, все, говорю, друг мой, в тебя за твою кротость и образование влюбляются. Я, говорю, с тебя, друг мой, воли не снимаю - ты сам умнее меня и образованнее; а когда ты задумаешь, открой, говорю, мне свои мысли, я тебе найду невесту. <..> Всякая, говорю, девушка за тебя пойдет с радостью, есть, говорю, у меня для тебя невеста и с богатством, и с красотой» ${ }^{1}$. А вот фрагмент чернового автографа «Богатых невест», где Цыплунова уговаривает своего сына жениться: «Чего тебе недостает? За тебя пойдет всякая невеста. Ты отлично идешь по службе, у тебя добрый характер, поведение твое безукоризненно. Ты можешь [выбирать] найти жену себе, какую хочешь; и хорошо образованную, и с деньгами, и красавицу. За кого бы ты ни посватался, за тебя отдадут с радостью» ${ }^{2}$. Почти без изменений этот монолог содержится и в цензурной писарской копии (Санкт-Петербургская государственная театральная библиотека), и в первопечатном тексте: «За тебя пойдет всякая невеста, чего тебе недостает? Ты отлично идешь по службе, у тебя добрый характер, поведение твое безукоризненно. Ты можешь выбрать жену, какую хочешь; и хорошо образованную, и с деньгами, и красавицу. За кого бы ты ни посватался, за тебя отдадут с радостью»³ [Островский 1876: 294].

\footnotetext{
1 Там же. Л. 30.

2 Там же. Л. 6 об.

${ }^{3}$ Островский А. Н. Богатые невесты. Цензурная писарская копия пьесы // СПбГТБ. I.1.4.57 № 456. Л. 10.
} 
Однако нельзя совсем проигнорировать тот факт, что имя «Глафира» возникло в сознании автора именно в отношении матери Цыплунова. Возможно, образ ее рифмовался у Островского с образом родственницы Мурзавецкой («Волки и овцы»), девушки здравомыслящей, практичной и прямой в обращении с людьми. Эти черты в полной мере присутствуют и в характере Анны Афанасьевны. Не исключено также, что имя «Глафира», означающее «воспитан-

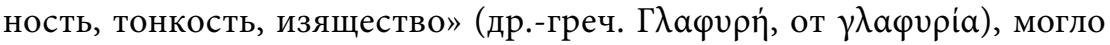
высветить и другую сторону психологического типа матушки Цыплунова, женщины деликатной в отношении чувств, понимающей и хорошо чувствующей другого человека. К слову сказать, ее образ остался почти не измененным от первых черновых набросков до второй печатной редакции пьесы. А вот характер ее сына претерпел некоторые коррективы.

В первоначальном варианте текста чернового автографа Цыплунов был представлен более резким и категоричным человеком в отношениях не только с Пирамидаловым, Бедонеговой и Белесовой, но и с горячо любимой матушкой. Например, в вышеупомянутом разговоре с Анной Афанасьевной о женитьбе в ответ на ее предложение найти для сына невесту Юрий Михайлович жестко отказывает матери: «Вы найдете, а я должен буду полюбить по вашему указанию. Нет, это невозможно». И далее, на незаконченную реплику Цыплуновой «Я тебе не посватаю такую невесту, как Бедонегова, хотя, впрочем, [мне кажется...]», герой отвечал дерзко и даже грубо: «Нет, уж. Не договаривайте! Хотя, впрочем, [у нее сто тысяч, хотите вы сказать] вам кажется, что сто тысяч такие деньги, за которые можно и продать себя. Я должен вас уважать, вы всякие такие подонки ${ }^{1}$ оставляйте в глубине души и пусть они не выплывают наружу никогда» ${ }^{2}$. В цензурной писарской копии и журнальной редакции пьесы ответ героя на предложение матери найти ему невесту звучит уже более мягко, и содержит в себе не категоричный отказ, а вопрос: «Вы найдете, а я, по вашему указанию, должен буду

\footnotetext{
1 Подонки - здесь: то, что остается на дне при отстое молока, изготовлении сыра, выкипании жидкости, перетопке сала, масла, воска и др.; остатки, осадки.

2 Островский А. Н. Бедная невеста. Черновой автограф пьесы // РГБ. Ф. 216. Л. 6 об.
} 
полюбить ее?» ${ }^{1}$ [Островский 1876: 294]. Более спокойной становится и реакция героя на замечание Анны Афанасьевны, что она не посватает «такую невесту, как Бедонегова», которая на Цыплунова «очень умильно поглядывает». Вместо пафосного монолога об унизительности самого предположения, что за сто тысяч «можно и продать себя», он только с горечью замечает: «Кабы вы знали, как обидны для меня и оскорбительны эти умильные ее взгляды!» ${ }^{2}$ [Островский 1876: 294].

Любая претензия к матери, а тем более порыв уличить или обвинить ее в чем-то исключаются драматургом из обрисовки характера главного героя. Его слишком горячий ответ матушке и нелицеприятные слова в ее адрес не вошли в окончательный текст пьесы. В процессе работы Островский все более придавал образу молодого человека мягкие, теплые интонации, свидетельствующие о намерении автора минимизировать в характере Цыплунова проявление бунтарства и юношеской непримиримости к традиционному укладу жизни. И даже после постановки и публикации первой редакции пьесы, и диалог матери с сыном о возможности женитьбы (д. I, явл. 4), и разговор Цыплунова с Белесовой (д. 2, явл. 2), и финал комедии, включающий в себя монолог Цыплунова с размышлениями о будущем, были существенно переработаны драматургом.

В отделе рукописей Института русской литературы (Пушкинский Дом) РАН хранится черновой автограф пьесы 1876 г., свидетельствующий о продолжении авторской работы над комедией после ее публикации. Произведенные драматургом коррективы указывают на его намерение придать сентенциям, звучащим в комедии, бо́льшую обобщенность, перевести диалоги, содержащие в себе смысловое ядро пьесы, из разряда нравоучений в область рассуждений. Кроме того, происходит изменение субъекта и объекта высказываний: вместо «я» всё чаще звучит «мы», вместо «он» или «она» - «они». Вот, например, фрагмент из сцены первой редакции разговора матери и сына Цыплуновых о Бедонеговой (д. I, явл. 4):

Островский А. Н. Богатые невесты. Цензурная писарская копия пьесы // СПбГТБ. I.1.4.57 № 456. Л. 10.

2 Там же. 
Ц ы п л у н о в. Да как же не обида? Она так смело смотрит в глаза, так уверена, что за свои сто тысяч может купить всякого.

Ц ы п л у н о в а. Ты уж очень строг к людям.

Ц ы п л у н о в. Нет, только к себе. Я других никогда не сужу, пусть живут, как знают, как умеют, только бы меня не трогали. Но если кто вздумает подкупить меня, дать мне взятку, и вообще склонить меня на какую-нибудь подлость, - тогда я обижусь глубоко. Как, не зная человека, подходить к нему прямо с грязью и говорить: «позвольте вас вымазать!» [Островский 1876: 295].

А вот аналогичный фрагмент из второй редакции пьесы:

Ц ы п л у н о в. Как же можно с ней говорить иначе, коли она чуть не бросается на шею каждому мужчине?

Ц ы п л у н о в а. Она богатая вдова, уж в летах; нельзя же требовать от неё, чтобы она вела себя, как институтка. Ей скучно жить одной; она хочет выйти замуж и употребляет для этого средства, какие знает. Впрочем, я никогда не слыхала, чтобы про неё говорили что-нибудь дурное; напротив, все её считают доброй и хорошей женщиной. Да и просто как женщина она имеет право требовать если не уважения, так по крайней мере учтивости с твоей стороны.

Ц ы п л у н о в. Ах, боже мой! Я готов уважать женщин, готов благоговеть перед ними; но зачем же они мелочны, зачем смешны! Вот чего им простить нельзя, не говоря уж о проступках.

Ц ы п л у н о в а. А за проступки ты бы казнил их смертной казнью? Ах, предоставь ты женщинам жить, как они хотят. Ты слишком тяжёлую опеку берёшь на себя: ведь их так много, мой друг!

Ц ы п л у н о в. Чего я не вижу, до того мне и дела нет. Но когда в моих глазах унижается тот высокий идеал, который я себе создал, когда женщины с какой-то навязчивой откровенностью обнаруживают свои самые непривлекательные стороны, - не могу же я не замечать этого. Вот отчего я и избегаю общества и предпочитаю уединение [Островский 1878: 105-106].

Легко заметить, что если в первом фрагменте весь разговор матери и сына касается конкретной житейской ситуации (Бедонегова кокетничает с Цыплуновым) и характеристики самой Бедонеговой, то во втором фрагменте герои от оценки ситуации и отдельной лич- 
ности переходят к размышлениям о женщинах «вообще» и об обществе в целом.

Ту же картину произведенных авторских изменений мы наблюдаем и в первом диалоге Цыплунова с Белесовой (д. II, явл. 2). Вот как звучало начало второго явления в первопечатном тексте:

Б е л е с о в а. Нет, как хотите, а я серьезных людей немножко боюсь.

Цы п л ун о в. Чего бояться их?

Б е л е с о в а. У них какие-то особые взгляды на жизнь, строгие требования.

Ц ы п л у н о в. У серьезных людей и взгляды на жизнь и на все серьезные, они других иметь не могут.

Б е л е с о в а. Ну и прекрасно, и пусть имеют; да зачем же они от других того же требуют? Ведь если 6 все были серьезны, было бы очень скучно жить на белом свете. Не правда ли, а? Что вы молчите?

Ц ы п л у н о в. Я слушаю вас.

Б е л е с о в а. Когда на меня смотрит кто-нибудь строгим, испытующим взглядом, мне так и хочется сказать ему: «Ну да, я легкомысленная женщина, но ведь я не мешаю вам быть серьезным, - не мешайте и мне быть легкомысленной». Ну, я хочу вас послушать, я много говорила [Островский 1876: 307].

А вот аналогичный фрагмент второй редакции:

Б е л е с о в а (с улыбкой мало скрытого неудовольствия). Очень вам благодарна. Я выслушала целую лекцию о нравственности и обязанностях человека. Я узнала, что такое серьёзные люди, что значит серьёзный взгляд на жизнь. Всё, что вы говорили, вероятно, очень умно, всё это очень полезно знать; и если я, к сожалению, мало поняла и мало воспользуюсь, - это уж моя вина.

Ц ы п л у н о в. Ах нет, в таком случае виноват я; кто хочет, чтоб его понимали, тот должен прежде выучиться ясно говорить.

Б е л е с о в а. Да, я согласна, но и себя не оправдываю. Надо уметь говорить обо всём и со всеми. Это не очень мудрено. Из бесчисленного множества красивых моральных фраз надо выучить несколько, чтобы уметь кстати вставить в разговор и своё слово. Хоть и очень редко, но может представиться такой случай, - как теперь, например. 
Ц ы п л у н о в. Ах, извините меня, сделайте одолжение! Будем говорить, о чём вам угодно, о чём вы привыкли. Говорить с вами для меня большое удовольствие; но я редко бываю в обществе; я не знаю, какие вопросы в ходу и об чём говорят теперь.

Б е л е с о в а (с раздражением). И теперь, как и всегда, говорят о том, что интересно и занимательно, и избегают того, что скучно, - например, всяких проповедей и поучений. И притом предполагается, что каждый это сам знает, что каждый учился всему этому... если он совершеннолетний. У всех были наёмные учителя и строгие наставники, которые так успели надоесть, что потом слушать даровых учителей не представляет уж особенного удовольствия. В разговоре вообще стараются не показывать слишком явно своего умственного или нравственного превосходства над прочими. Надо щадить людей. Когда кто-нибудь с уверенностью полного мастера говорит об обязанностях человека, - простые смертные, люди легкомысленные, такие, как я, должны думать, что этот урок относится к ним, что эта филиппика есть косвенное порицание их легкомысленного поведения. Ну, и конфузишься... торжествовать над нами легко. Но, мне кажется, и мы имеем право сказать учителю: да, мы легкомысленны; но мы не мешаем вам быть святым, не мешайте и нам быть грешными! Научить вы нас не научите, а оскорбить можете» [Островский 1878: 123-124].

Мы видим, что диалог второго явления первой редакции сосредоточен исключительно на частной житейской ситуации, в которой оказались герои. Валентина Васильевна сообщает о своем страхе перед «серьезными людьми», заведомо зная, что будет ими осуждена. Цыплунов говорит исключительно о ней, предмете своего обожания, и только в силу контекстной необходимости делает обобщенное замечание об упомянутых героиней «серьезных людях»: «У серьезных людей и взгляды на жизнь и на все серьезные, они других иметь не могут» [Островский 1876: 307].

Начало второго явления второй редакции пьесы уже несколько иное: оно представляет собой продолжение скрытого от зрителей и читателей разговора молодых людей, в котором Цыплунов уже высказал свои воззрения, прочитав любимой девушке «лекцию о нравственности и обязанностях человека». Таким образом, самое начало разговора героев разрывает узкий круг частных жизненных обстоятельств и выводит нас в область социальных и мировоззренческих размышлений. 
И сама Белесова здесь ведет речь не о себе, не только о себе, а о таких, как она, «простых смертных, людях легкомысленных».

Но основные изменения, сделанные Островским и вошедшие во вторую редакцию пьесы, коснулись, прежде всего, характера и манер самого Юрия Михайловича Цыплунова. Его поведение должно было стать более спокойным, выдержанным, придавая всему образу в целом бо́льшую емкость и глубину. Вот некоторые примеры коррективов реплик героя, сделанные Островским в 1876 г. В первопечатном тексте в ответ на претензию Бедонеговой, что молодой человек игнорирует ее общество, Цыплунов торопливо и не вполне уверенно (о чем свидетельствуют повторяющиеся многоточия и словоерсы) отвечал: «Извините-с, ...я - человек занятой-с... я завтра к вам зайду» [Островский 1876: 292]. В черновом автографе ИРЛИ РАН отображен процесс нового авторского поиска нужных слов, соответствующих интонаций для выражения более весомого и спокойного и в то же время несколько ироничного отношения взрослого мужчины к заигрываниям простоватой и глуповатой особы: «Что делать! [Нужно] К сожалению, я должен признаться, что [я] своей особой не могу ${ }^{1}$ доставить много практики для вашего [слишком] чувствительного сердца $»^{2}$. В окончательном, печатном варианте второй редакции реплика зазвучала сдержанно и лаконично: «Что делать! К сожалению, я должен признаться, что не могу своей особой доставить много практики для вашего чувствительного сердца» [Островский 1878: 105].

Именно на нее с укором отзывается Анна Афанасьевна: «Это грубо, мой друг, так не говорят с женщинами» [Островский 1878: 105]. Этот укор свидетельствует о другой расстановке сил любящей матери и ее взрослого сына, об изменении роли самого Цыплунова в драматическом сюжете. Того Юру, который лепетал «Извините-с, ...я - человек занятой-с... я завтра к вам зайду», Анна Афанасьевна, по-матерински оберегавшая, заботливо опекавшая своего слишком ранимого мальчика, могла только умоляюще попросить: «Юша, пойдем к ней! Развлекись немного» [Островский 1876: 293]. Этого, нового Юру и она, и другие лица пьесы, в соответствии с исправлениями, сделанными рукой

\footnotetext{
${ }^{1}$ Исправлено на: не могу своей особой.

${ }^{2}$ Островский А. Н. Богатые невесты. Черновой автограф пьесы // ИРЛИ. Ф. 218. Л. 9.
} 
драматурга, называют уже не Юша, а Жорж ${ }^{1}$. С этим нелюдимым, но вполне самодостаточном и хорошо осознающим себя человеком она вступает в спор, для нежно любящей матери даже слишком трезво оценивая негативные стороны его прямолинейной натуры: «И всегда виноват ты сам, потому что ты никогда не даешь себе труда разглядеть хорошенько женщин, которых ты удостоиваешь своей любви <...>. Вы, чистые натуры, не только не прощаете, но даже готовы оскорбить любимую женщину, если она не похожа на те бледные, безжизненные шаблоны, которые созданы вашим досужим воображением» [Островский 1878: 108]. Думается, что произведенные драматургом изменения в обрисовке характера главного героя стали главной причиной, вызвавшей необходимость корректировки сцен и первого, и финального разговоров Цыплунова с Валентиной Васильевной Белесовой - женщиной, которую он «удостоил своей любви».

Принципиальные изменения в первой сцене (д. II, явл. 2) коснулись речевого поведения героя в общении с предметом его любви. В отличие от первопечатного текста, речь Цыплунова в диалогах второй редакции комедии становится более изящной и комплиментарной, обращение к даме - более деликатным. Он каждым высказыванием подчеркивает ее значимость и превосходство, свою подчиненность и трепет перед ее совершенством: «Ах нет, в таком случае виноват я», «Ах, извините меня, сделайте одолжение! Будем говорить, о чем вам угодно, о чем вы привыкли. Говорить с вами для меня большое удовольствие» [Островский 1878: 124], «Прекрасные правила у вас», «О, конечно, для такой богато одаренной натуры к чему правила», «Я вас давно знаю, вы ничего не изменились, - вы так же искренны, как и прежде, когда были ребенком», «Я не смел мечтать о счастии возобновить знакомство с вами; я думал, что опять потеряю вас из виду, и хотел наглядеться на вас, чтобы ясней и дольше удерживать ваш очаровательный образ в своей памяти» [Островский 1878: 125] и т. д.

Для сравнения приведем аналогичный ряд обращенных к Белесовой реплик Цыплунова из текста первой редакции пьесы: «Чего бояться их?», «Я слушаю вас», «У вас прекрасные правила», «Значит, у вас прекрасная, богато одаренная натура, и тогда на что вам какие-нибудь правила!» [Островский 1876: 307], «О! Ведь я вас давно знаю, и вы не изменились, вы так же искренны, как и прежде, когда были ребенком»,

1 Там же. Л. 10, 11 об., 14, 20. 
«Я хотел наглядеться на вас, чтоб ясней и дольше удерживать ваш очаровательный образ в своей памяти...» [Островский 1876: 308].

Нетрудно заметить, как изменился общий тон речи героя, ставшей более витиеватой и свободной. И даже те редкие комплименты, которые входили в первую редакцию пьесы, претерпели существенные изменения: стали более пространными и утратили первоначальную угловатость. Казалось бы, один и тот же смысл в словах «У вас прекрасные правила» (1-я редакция) и «Прекрасные правила у вас» (2-я редакция). Но в первом случае это звучит как торопливо-прямолинейная оценка и констатация факта, а во втором - как размышление, открывающаяся истина, восхищение. Или другой пример: «Значит, у вас прекрасная, богато одаренная натура, и тогда на что вам какие-нибудь правила!» (1-я редакция) звучит как логическое заключение, содержащее прямолинейную оценку качества объекта. А фраза «О, конечно, для такой богато одаренной натуры к чему правила» (2-я редакция) сориентирована на эмоциональный отклик и указывает не столько на факт оценки, сколько на нежелание объективно оценивать и объект, и ситуацию, поскольку «одаренность натуры» визави утверждается априори.

Существенные коррективы внес драматург и в финал пьесы, «заставив» Цыплунова отказаться от излишней социальной патетики. В финале первой редакции герой не позволял любимой девушке поцеловать руку своей матушки: «Нет, рано еще, рано, не теперь. Вот маменька станет вас любить, станет вас учить всему доброму, хорошему, а я... а я... буду опять бродить по лесу и мечтать о том ангеле-ребенке, которого я любил и люблю, образ которого в моих глазах потускнел на минуту... И вот, когда она вас научит работать, трудиться, когда она научит вас чувствовать так, как мы чувствуем, может быть, и вы полюбите уединенные прогулки. И вот когда-нибудь, после дневного труда, взволнованные сочувствием к несчастию и горю ближнего, вы выдете подышать свежим вечерним воздухом и помечтать о лучшей будущности для человечества, может быть, я вас встречу и увижу детскую чистоту и ясность в прекрасных чертах вашего лица; тогда рай, о котором я мечтаю, будет для меня возможен» [Островский 1876: 346]. Во второй редакции финальный монолог Цыплунова сводится к трем строкам, свидетельствующим о любви, прощении и лиричном приятии той жизни, о которой грезило его мягкое сердце: «Об чем же мне думать! И я нашел то, чего искал. В этих прекрасных чертах опять я вижу 
детскую чистоту и ясность и то же ангельское выражение... Это она, наша прежняя Валентина» [Островский 1878: 176].

Таким образом, новая редакция пьесы оказалась сориентирована не столько на постановку и раскрытие злободневных вопросов общественной жизни, сколько на утверждение вечных моральных и нравственных ценностей как основы любого общественного устройства. Из текста комедии были исключены практически все высказывания Цыплунова, указывающие на принадлежность героя к прямым последователям «нигилистов» и «позитивистов».

Кроме того, было очевидно намерение Островского отказаться от классицистической модели построения драматического конфликта, в котором взаимодействуют не столько личности, сколько социальные типы, наделенные характерными именами. Это коснулось прежде всего образов Пирамидалова и Бедонеговой. По всему тексту рукописи фамилия Пирамидалов была исправлена на «Петров», а Бедонегова на «Неженову». Возможно, драматург намеревался лишить образ Пирамидалова черт некоторой гротескности, подчеркнуть его обычность и типичность: Петров - одна из самых распространенных и потому нейтральных фамилий в России. И в образе Бедонеговой, «утратившей» в своей фамилии корень «-бед-», также устранялась ироничная аллюзия на идиому «бедная вдова» или лексему «бедолага», которые в сочетании с корнем «-нег-» (нега, удовольствие, наслаждение, блаженство) формировали семантически «перегруженный» гротесковый характер. Исследователи, занимающиеся изучением содержательного аспекта имен собственных в текстах драматурга, отмечают тенденцию постепенного отказа Островского от слишком открытой атрибуции персонажа посредством имени. «Если в раннем периоде творчества это нередко имена-ярлыки, семантика которых очевидна, то в позднем наиболее часты случаи скрытой семантики...» [Тугарина 2003: 203].

Однако эти исправления, внесенные в рукопись чернового автографа, не вошли в печатный текст второй редакции пьесы, и оба персонажа сохранили свои прежние фамилии: Пирамидалов и Бедонегова. Рискнем предположить, что изменение имен героев диссонировало с общим строем пьесы, нарушало слаженное созвучие образов. «В совокупности все лица составляют систему: главные герои окружены

Там же. Л. 9. 
второстепенными, эпизодическими, фоновыми, или “аксессуарными"», - пишет Л. В. Чернец, характеризуя образную систему пьес А. Н. Островского [Чернец: 24]. Потому любое изменение «фоновых» персонажей, представляющих собою, как правило, по формулировке того же исследователя, «вариации» какого-либо типа [Чернец: 29], неизменно должно было привести к деформации всей системы, отразиться на общем строе комедии.

Та же история случилась и с обращениями, исправленными рукой Островского по всему тексту пьесы. Вместо привычных для провинциального уклада русской жизни обращений по имени и отчеству: Анна Афанасьевна, Юрий Михайлович, Всеволод Вячеславович, Виталий Петрович в черновом автографе комедии возникли «господин Петров», «господин Цыплунов» и «господин Гневышов»; «мадам Цыплунова», «мадам Бедонегова» и «мадемуазель Валентина». Но ни эти холодноофициальные наименования действующих лиц, ни упомянутое выше имя «Жорж» вместо прежнего «Юша» в обращении к Юрию Михайловичу Цыплунову не вошли в печатный текст комедии, опубликованной в девятом томе собраний сочинений А. Н. Островского в 1878 г. Видимо, почувствовав чужеродность внесенных изменений общему звучанию произведения, драматург отказался от сделанных корректив и вернулся к прежнему варианту текста. Таким образом, «наскоро написанная пьеса» лишь отчасти поддалась позднейшей корректировке автора только в одной из своих составляющих - организации характера главного героя. Остальное поле комедии осталось практически без изменений.

Действительно, «Богатых невест» вряд ли можно назвать жемчужиной драматургии Островского. В них представлены не слишком яркие типы, не слишком острый конфликт, незамысловатый драматический сюжет, но произведение обладает идейной и художественной целостностью, возможно, не всегда воспринимаемой поверхностным взглядом. Эта комедия стоит в ряду других, подчас столь же бесхитростных и незамысловатых пьес, которые просто и понятно говорят с читателем и зрителем о нем самом. «Но эта кажущаяся простота оборачивается, в конечном счете, глубокой жизненной мудростью, - замечает Ю. В. Лебедев. - Русский драматург предпочитает с демократическим простодушием не усложнять в жизни простое, а упрощать сложное, снимать с героев покровы хитрости и обмана, интеллектуальной изощренности и проникать в сердцевину вещей и явлений» [Лебедев: 552-553]. 


\section{Список литературы \\ Источники}

«Богатые невесты» на Александринской сцене // Голос. 1875. № 331.30 ноября. C. 2.

M., В. [Марков В. В.] Литературная летопись. «Богатые невесты» // Петербургские ведомости. 1876. № 65. 6 марта. С. 1-2.

Островский А. Н. Богатые невесты // Отечественные записки. 1876. Т. 224. № 2 (февраль). С. 283-346.

Островский А. Н. Богатые невесты // Сочинения А. Островского. М.: Изд-во Ф. И. Салаева, 1878. Т. 9. С. 91-176.

\section{Исследования}

Лебедев Ю. В. Творчество А. Н. Островского 1864-1870 годов // Островский А. Н. Полн. собр. соч.: в 18 т. Кострома: Костромаиздат, 2020. Т. 3. С. 545-554.

Миловзорова М. А. Об особенностях интриги в поздних пьесах А. Н. Островского // Щелыковские чтения 2002. Проблемы поэтики и эстетики творчества А. Н. Островского. Кострома: Авантитул, 2003. С. 42-53.

Смирнова Л. Богатые невесты // Островский А. Н. Полн. собр. соч.: в 12 т. М.: Искусство, 1975. Т. 4. С. 516-522

Тугарина Н. С. Имя - герой - образ // Щелыковские чтения 2002. Проблемы поэтики и эстетики творчества А. Н. Островского. Кострома: Авантитул, 2003. С. 194-205.

Тугарина Н. С. О «Словаре антропонимов в произведениях А. Н. Островского» // А. Н. Островский. Материалы и исследования: Сборник научных трудов. Шуя: ШГПУ, 2010. Вып. 3. С. 233-239.

Фаркова Е. Ю. Богатые невесты // А. Н. Островский. Энциклопедия / гл. ред. и сост. И. А. Овчинина. Кострома: Костромаиздат; Шуя: ШГПУ, 2012. С. 66-67

Холодов Е. Г. А. Н. Островский в 1873-1877 годах // Островский А. Н. Полн. собр. соч.: в 12 томах. М.: Искусство, 1975. Т. 4. С. 460-494.

Чернеи Л. В. Персонаж, характер, тип в пьесах А. Н. Островского // А. Н. Островский. Материалы и исследования. Шуя: ШГПУ, 2008. Вып. 2. С. 22-31. 


\section{References}

Lebedev, Iu. V. “Tvorchestvo A. N. Ostrovskogo 1864-1870 godov” [“A. N. Ostrovsky's Works of 1864-1870"]. Ostrovskii, A. N. Polnoe sobranie sochinenii: $v 18$ t. [Complete Works: in 18 vols.], vol. 3. Kostroma, Kostromaizdat Publ., 2020, pp. 545-554. (In Russ.)

Milovzorova, M. A. "Ob osobennostiakh intrigi v pozdnikh p'esakh A. N. Ostrovskogo" ["On the Peculiarities of Intrigue in A. N. Ostrovsky's Late Plays"]. Shchelykovskie chteniia 2002. Problemy poetiki i estetiki tvorchestva A. N. Ostrovskogo [Shelykovo Proceedings 2002. Issues of Poetics and Aesthetics of A. N. Ostrovsky's Work]. Kostroma, Avantitul Publ., 2003, pp. 42-53. (In Russ.)

Smirnova, L. "Bogatye nevesty" ["Rich Brides"]. Ostrovskii, A. N. Polnoe sobranie sochinenii: v 12 t. [Complete Works: in 12 vols.], vol. 4. Moscow, Iskusstvo Publ., 1975, pp. 516-522. (In Russ.)

Tugarina, N. S. "Imia - geroi - obraz" ["Name - Hero - Image"]. Shchelykovskie chteniia 2002. Problemy poetiki i estetiki tvorchestva A. N. Ostrovskogo [Shchelykovo Proceedings 2002. Issues of Poetics and Aesthetics of A. N. Ostrovsky's Work]. Kostroma, Avantitul Publ., 2003, pp. 194-205. (In Russ.)

Tugarina, N. S. “O 'Slovare antroponimov v proizvedeniiakh A. N. Ostrovskogo"' ["On the 'Dictionary of Anthroponyms in A. N. Ostrovsky's Works."]. A. N. Ostrovskii. Materialy i issledovaniia: Sbornik nauchnykh trudov [A. N. Ostrovsky. Materials and Studies: A Collection of Scientific Papers], issue 3. Shuia, ShGPU Publ., 2010, pp. 233-239. (In Russ.)

Farkova, E. Iu. "Bogatye nevesty" ["Rich Brides"]. A. N. Ostrovskii. Entsiklopediia [A. N. Ostrovsky. Encyclopedia], ed. and comp. by I. A. Ovchinina. Kostroma, Kostromaizdat Publ.; Shuia, ShGPU Publ., 2012, pp. 66-67. (In Russ.)

Kholodov, E. G. “A. N. Ostrovskii v 1873-1877 godakh” [“A. N. Ostrovsky in 18731877”]. Ostrovskii, A. N. Polnoe sobranie sochinenii: v 12 tomakh [Complete Works: in 12 vols.], vol. 4. Moscow, Iskusstvo Publ., 1975, pp. 460-494. (In Russ.)

Chernets, L. V. "Personazh, kharakter, tip v p'esakh A. N. Ostrovskogo" ["Character, Kind, Type in A. N. Ostrovsky's Plays"]. A. N. Ostrovskii. Materialy i issledovaniia [A. N. Ostrovsky. Materials and Studies], issue 2. Shuia, ShGPU Publ., 2008, pp. 22-31. (In Russ.) 


\author{
(C) 2021. М. А. Смирнова \\ Российская национальная библиотека, \\ Санкт-Петербургский Институт истории РАН \\ г. Санкт-Петербург, Россия
}

\title{
Автобиографическое наследие и судьба личного архива русского юмориста Николая Александровича Лейкина
}

\author{
Исследование выполнено при финансовой поддержке \\ Российского научного фонда в рамках научного проекта № 21-78-00072
}

\begin{abstract}
Аннотация: Статья посвящена обзору автобиографических произведений и личного архива русского юмористического писателя Николая Александровича Лейкина. Его фигура традиционно привлекала внимание литературоведов в связи с творчеством А. П. Чехова, ранние рассказы которого Лейкин печатал в издаваемом им журнале «Осколки». В то же время обширное и интересное автобиографическое наследие юмориста почти не исследовано и до сих пор не опубликовано полностью. В статье приведен обзор известных на сегодняшний момент рукописных и опубликованных автобиографических произведений Н. А. Лейкина: воспоминаний, записок и дневников. Отдельный сюжет составляет судьба личного архива писателя и характеристика его материалов в архивохранилищах России. В катаклизмах первой половины XX в. архив Лейкина был рассредоточен и разделен на три части. По счастливой случайности многие документы уцелели и пополнили собрания государственных архивов, но некоторые дневники и рукописные воспоминания до сих пор не найдены. Изучение сохранившихся томов дневников позволяет говорить об их уникальности. Помимо значимости для научного сообщества, дневники будут интересны широкому кругу читателей, так как они воссоздают картину жизни российского общества на пороге кардинальных изменений в стране.
\end{abstract}

Ключевые слова: автобиографический жанр, Н. А. Лейкин, дневники, мемуары, личный архив, рукописи.

Информация об авторе: Мария Александровна Смирнова, кандидат исторических наук, Российская национальная библиотека, ул. Садовая, 18, 191069; Санкт-Петербургский Институт истории РАН, ул. Петрозаводская, 7 197110, г. Санкт-Петербург, Россия. ORCID ID: https://orcid.org/0000-0001-9756-2699

E-mail: smirnmar@gmail.com

Дата поступления статьи в редакиию: 29.04 .2021

Дата одобрения статьи рецензентами: 14.06 .2021

Дата публикации статьи: 30.09.2021

Для цитирования: Смирнова М. А. Автобиографическое наследие и судьба личного архива русского юмориста Николая Александровича Лейкина // Два века русской классики. 2021. Т. 3, № 3. С. 160-171. https://doi.org/10.22455/2686-7494-20213-3-160-171 


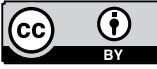

This is an open access article distributed under the Creative Commons Attribution 4.0 International (CC BY 4.0)
Dva veka russkoi klassiki,

vol. 3, no. 3, 2021, pp. 160-171. ISSN 2686-7494

Two centuries of the Russian classics,

vol. 3, no. 3, 2021, pp. 160-171. ISSN 2686-7494

Research Article

(C) 2021. Maria A. Smirnova

National Library of Russia,

Saint Petersburg Institute of History of Russian Academy of Sciences

St. Petersburg, Russia

\section{Autobiographical Heritage and the Fate of the Personal Archive of the Russian Comic Writer Nikolai Alexandrovich Leykin}

Acknowledgments: The reported study was funded by the Russian Science Foundation according to the research project number 21-78-00072.

Abstract: The article is devoted to a review of autobiographical works and the personal archive of the Russian humorous writer Nikolai Aleksandrovich Leykin. His figure traditionally attracted the attention of literary critics in connection with the work of A. P. Chekhov, whose early stories appeared in the journal Oskolki published by Leykin. At the same time, the humorist's extensive and interesting autobiographical legacy has hardly been studied and fully published. The article provides an overview of the currently known handwritten and published autobiographical works of N. A. Leykin: memoirs, notes and diaries. A separate issue is the fate of the writer's personal archive and the characteristics of his materials in the archives of Russia. In the cataclysms of the first half of the $20^{\text {th }}$ century Leykin's archive was dispersed and divided into three parts. By a lucky coincidence, many documents survived and entered the state archives, but some diaries and handwritten memoirs have not yet been found. The study of the extant volumes of the diaries allows us to speak about their uniqueness. In addition to being important for the scientific community, the diaries will be of interest to a wide range of readers, as they recreate the picture of the life of Russian society on the eve of cardinal changes.

Keywords: autobiographical genre, N. A. Leykin, diaries, memoirs, personal archive, manuscripts.

Information about the author: Maria $\mathrm{A}$. Smirnova, $\mathrm{PhD}$ in Historical Sciences, National Library of Russia, Sadovaya 18, 191069; Saint Petersburg Institute of History of Russian Academy of Sciences, Petrozavodskaya 7, 197110 St. Petersburg, Russia. ORCID ID: https://orcid.org/0000-0001-9756-2699

E-mail: smirnmar@gmail.com

Received: April 29, 2021

Approved after reviewing: June 14, 2021

Published: September 30, 2021

For citation: Smirnova, M. A. "Autobiographical Heritage and the Fate of the Personal Archive of the Russian Comic Writer Nikolai Alexandrovich Leykin." Dva veka russkoi klassiki, vol. 3, no. 3, 2021, pp. 160-171. (In English.) https://doi.org/10.22455/2686-74942021-3-3-160-171 
December 2021 marks $180^{\text {th }}$ anniversary of the birth of the Russian comic writer Nikolai Alexandrovich Leykin (1841-1906). Popular and widely read in the second half of the 19th century, he was practically forgotten as a writer after his death. However, Leykin rightfully reaps the laurels of the discoverer of the genius of Chekhov, whose early writings he published in his humorous weekly magazine Oskolki (Fragments).

Since Leykin was not among the major figures of Russian literature, his brief biography should be outlined. A writer to be was born in 1841 into a merchant family ${ }^{1}$. The Leykins belonged to one of the oldest merchant clans, that carried on trading activities in Oranienbaum, a town near St. Petersburg, from the middle of the 18th century and since 1784 in the capital itself [Leykin 2003: 124]. Unlike many men from a tiers etat who joined the ranks of St. Petersburg intelligentsia, Leykin never broke with his merchant origin. Throughout his life he was first in the Petersburg guild merchant class, later in 1884 was included in the estate of hereditary deserved citizenry - a special privileged stratum of the Russian society for distinguished citizens ranked above merchantry and below nobility ${ }^{2}$. After graduating from the Reformed Secondary School, Leykin served as a counterman, and later maintained a store and a book warehouse in Gostiny Dvor [Shilovskikh 1999: 19]. However, the main brainchild of the writer was the humorous magazine Oskolki, published by him from 1881 to 1906 . In his magazine Leykin publicized more than 270 works of the unfledged author Chekhov [Belotserkovskaya; Chudakov 1968; Shvetsova].

Nikolai Leykin occupied a significant place in the capital city selfgovernment - since 1881 he was elected representative from the St. Petersburg merchant class and a member of the St. Petersburg

Institute of Russian Literature of the Russian Academy of Sciences. Manuscript Department. F. 149. No. 85. Fol. 1.

2 Russian State Historical Archive. F. 1343. Reg. 39. No. 2720. 
City Duma, as well as the Executive Committee man for the organization of schools, a trustee of many charitable institutions, etc. [Baryshnikov: 262].

The first Leykin's attempts at writing date back to the turn of the 1850s-1860s, when he became addicted to reading and in his free hours in the stockroom began to indite verses first, and then to write in prose [Leykin 2003: 188-199]. Pretty soon the author found his genre - humorous sketches and scenes from merchant life became his hallmark throughout his entire career. In them, he "exposed with vivid sharpness the wild, ignorant, backward life, which nourished the atmosphere from which he came from" [Shilovskikh 1999: 4]. Among the most famous works of Leykin the early essays Apraksintsy (The Apraksins), The Stock Artel Workers, collections of sketches Our Folk Abroad, Scenes from merchant life, etc. are noteworthy. These simple stories and scenes were republished repeatedly and were popular among the reading public of the middle-class readers as a sleek entertaining fiction [Reitblat: 639$]^{1}$.

In contrast to the reading public, critics were not so lenient towards Leykin's fictive talent. Many of them considered his works undeserving of attention, lightweight and futile, written for the public's demand. However, there were also those who were able to see something more in Leykin's humor. Especially his early works Apraksintsy (The Apraksins) and The Stock Artel Workers, written in a spirit of democratic literature of the 1860s deserved high praise. Rare for the writer novels and stories (Christ's Bride, Piece of Bread, etc.) were received in the press well. The texts and characters of Leykin's essays were also often praised by readers and were extremely in demand in the circles of the reading public from merchants and bourgeoisie. A friend of the writer, litterateur N. M. Yezhov, wrote about the popularity of the characters of Leykin's essays Our Folk Abroad: “This couple has become such a huge success that this summer, wherever I happened to be, I heard talk about them"2. However, the general opinion of Russian prerevolutionary criticism about the writer's oeuvre can be summed up in the words of journalist A. A. Sokolov: "Leykin, having written a lot, at the same

\footnotetext{
${ }^{1}$ Numerous literary works of N. A. Leykin were reprinted many times both during the life of the writer and in recent years. Within the framework of this article, the author does not see it possible to cite even his selected bibliography and refers readers to the dictionary entries [Tikhomirov; Kataev 1994].

2 National Library of Russia. Manuscript Department. F. 248. No. 183. Fol. 8v.
} 
time, one might say, did not write anything that would give him the right to immortality" [Sokolov 17: 15]. Soviet and modern Russian literary criticism traditionally considers Leykin in the context of the literature of the writers of Chekhov's age, as well as in connection with the formation of the literary style of early Chekhov, but in general giving scanty attention to Leykin's personality and work [Kataev 1981; Kataev 1982; Chudakov 1986: 102]. As an independent phenomenon Leykin's fiction became the subject of research only in the dissertation and articles of I. S. Shilovskikh [Shilovskikh 1999; Shilovskikh 2000]. For the first time, the author reconstructed the writer's biography, analyzed the main genre forms of his works, described his literary contacts and reconstructed his "rather variegated and artistically unequal heritage" [Shilovskikh 1999: 57]. In recent years, several articles concentrated on certain aspects of Leykin's work [Morozova; Ovcharskaya, etc.].

If Leykin's literary work is fairly well known, then his autobiographical heritage remains terra incognita. With the exception of memoirs about his childhood and early years, most of Leykin's autobiographical works are scattered, poorly studied, and remain in manuscripts. The studied complex may be divided into three main parts: memoirs, autobiographical notes and diaries ${ }^{1}$.

The most well-known work in the autobiographical heritage of Nickolai Leykin is his memoirs, which he started to write shortly before his death, having managed to describe only his childhood, youth years and life until the mid-1860s. The writer described the circumstances of working in his diary entries for December 1905: "I wrote my memoirs two years ago and now it is possible to mention in them what could not be said under the censorship of that time"2. Leykin's death interrupted the publication of chapters of memoirs in the Istorichesky Vestnik (History Herald) historical and literary magazine [Leykin 1906]. In a letter to the editor of the magazine S. N. Shubinsky the writer's widow Praskovia Nikiforovna Leykina reported about the finding of a draft of the next chapter of his husband's memoirs after his death and suggested to publish them ${ }^{3}$.

1 The detailed description of all the autobiographical works of Leykin see in another article of the author [Smirnova].

2 Institute of Russian Literature of the Russian Academy of Sciences. Manuscript Department. F. 149. No. 75. Fol. 30v.

3 National Library of Russia. Manuscript Department. F. 874. Reg. 1. No. 105. Fol. 178. 
In 1907, Leykin's memoirs were published in a separate volume, together with his correspondence and biographical article [Nikolai Aleksandrovich Leykin]. Interest in Leykin personality and his memoirs arose in the 2000s, when they were republished twice - in a book with comments by A. M. Konechny [Leykin 2003] and in the History of Petersburg journal [Leykin 2003-2004]. In addition to the full publications of the text, several fragments of Leykin's memoirs related to M. E. Saltykov-Shchedrin and N. A. Nekrasov were also reprinted [Smirnova: 264-265].

A significant place in Leykin's memoir heritage belongs to various autobiographical notes, similar in composition, style and phraseology: of a small volume (from half a page to several sheets), with a chronological order of narration, in most of the texts the author wrote about his life in childhood and youth before the beginning of professional studies in literature, and only in one he skated over these subjects, drawing attention to the main points of his literary career. These notes have been preserved both in manuscripts and as published texts in the amount of eleven works [Leykin 1888; Leykin 1903] ${ }^{1}$. Analysis of all the notes indicates significant loans in the texts - at least the plots and their arrangement coincide. The information about Leykin's work on autobiographical writing may be found in his correspondence. In a letter to the literary historian S. A. Vengerov dated January 30, 1896, Leykin deduced a formula for his work on autobiographical notes, which consisted in constant revision of what he had already written: "It is difficult to compose information about yourself every time, and they often ask me. Yes, and I want to add the ending to the manuscript" ${ }^{2}$.

Another autobiographical work of Leykin are his diaries that still remain unpublished due to their considerable volume and the very specific handwriting of the author. Several volumes of the writer's diaries for years $1892-1894,1895-1902^{3}$, as well as a notebook of his diary for 1905 survived

\footnotetext{
${ }^{1}$ National Library of Russia. Manuscript Department. F. 66. No. 1. Fol. 160; Institute of Russian Literature of the Russian Academy of Sciences. Manuscript Department. F. 93. Reg. 3. No. 716; F. 49. No. 84. Fol. 4-5, 7, 9-9v.; F. 273. Reg. 2. No. 92; F. 274. Reg. 2. No. 396. Fol. 106 v.; No. 398. Fol. 146v.; F. 377. Reg. 7. No. 2119. Fol. 5-6 v.; Russian State Archive of Literature and Arts. F. 289. Reg. 1. No. 51 .

${ }^{2}$ Institute of Russian Literature of the Russian Academy of Sciences. Manuscript Department. F. 377. Reg. 7. No. 2119. Fol. 3.

${ }^{3}$ Russian State Archive of Literature and Arts. F. 289. Reg. 3. No. 1-4.
} 
to this day ${ }^{1}$. It is known that Leykin began keeping a diary immediately after graduating from the Reformed Secondary School and carried it on for fortysix years [Gitovich: 500]. In addition to the extant handwritten volumes, we know about a diary for year 1904, since a text selection from it was placed in the Nikolai Alexandrovich Leykin in his memoirs and correspondence in 1907 [Nikolai Aleksandrovich Leykin: 242-243].

Literary critics appreciated the information value of Leykin's diaries quite early: in 1940, in the Novy Mir magazine, G. Prokhorov published twenty-two letters of A. P. Chekhov addressed to Leykin and sixteen Leiykin's letters to Chekhov [Iz perepiski]. In the prolusion, among other issues, the researcher turned to the materials of the writer's diaries, describing them as "several volumes of Leykin's interesting diaries for the 90s and 900s" [Iz perepiski: 229]. Twenty years later, N. I. Gitovich prepared the publication of a diary fragment in the $68^{\text {th }}$ volume of Literaturnoye Nasledstvo (Literary Heritage) almanac and described their value as follows: "The diaries record political, social, literary and theatrical events and, sometimes, their assessments by Leykin" [Gitovich: 500].

It should be noted that Leykin's diaries, in contrast to his memoirs, were studied only as a source of information about the life of his great contemporaries, and not as his autobiographical work. Meanwhile, this narrative is a rich material for the literary and social life of the turn of the century, both from a factual point of view and from the author's. Turning to the diary for 1905, a vivid description of the political processes in Russia and a sense of impending cataclysms may be found. Leykin's humorous novelistic style gives way to harsh assessments of current events. As a case the response to the RussoJapanese War is put: "The fleet of Admiral Rozhestvensky, passing Singapore, entered the Yellow Sea - and again there is delight in the newspapers and again chauvinism. The leading singer in Novoye Vremya shouts that this is the greatest feat in history, that even if Rozhestvensky is defeated, then this will still cause great damage to Japan. So this was what he had come to!" ${ }^{2}$. Events of national policy worried the writer no less: "Violence, robberies, armed attacks on the public and the public on the police, political murders are so frequent in St. Petersburg, Moscow and the provinces that I stopped recording them.

Institute of Russian Literature of the Russian Academy of Sciences. Manuscript Department. F. 149. No. 74.

2 Ibid. fol. $4 \mathrm{v}$. 
The licentiousness is even among the soldiers. In Galley Harbor yesterday a crowd of drunken sailors attacked the police officer and knocked him rotten. Defending himself, he fired a revolver and wounded four. The sailors were lightly wounded, so they fled. But because of their wounds, they were caught in the barracks for their attack on the police officer"1.

The question of the personal archive of N. A. Leykin is closely related to his autobiographical heritage and is a subject of particular interest. Currently, it is divided into three large parts and is stored in three archives in Moscow and St. Petersburg: the Manuscript Department of the National Library of Russia (NLR), the Russian State Archive of Literature and Art (RGALI), and the Manuscript Department of the Institute of Russian Literature of the Russian Academy of Sciences (The Pushkin House).

The most extensive part of Leykin's archive is stored in the Manuscript Department of the Institute of Russian Literature and constitute a personal archival fond (f. 149) consisting of 207 items for 1850-1918. The collection contains the entire range of documents - literary materials, personal, financial and economic documents of Leykin, his correspondence, materials of the Oskolki magazine. Several versions of the writer's autobiographical notes and the last notebook of his diary for 1905 are also stored in this part of his archive.

The second part of Leykin's archive is located in the Russian State Archive of Literature and Art (f. 289) and contains 88 items for 1849-1906. Mostly they are letters addressed to Leykin, as well as his biographical notes and photographs. The third inventory includes a set of the writer's most valuable diaries for 1892-1902. The materials entered the archive in 1941, and until that time were stored in the holdings of the State Literary Museum.

The writer's archive in the Manuscript Department of the National Library of Russia also constitutes separate archival fond (f. 427) and includes 72 items from 1867 to 1905 . For the greater part, the collection contains letters received by Leykin from his correspondents, and his detailed letters to his wife Praskovya Nikiforovna, written during rare cases of parting ${ }^{2}$. These letters are of autobiographical character and depict Leykin's days with almost diary accuracy. These materials were achieved by the library in two parts in 1943 and 1949.

${ }^{1}$ Ibid. fol. $5 \mathrm{v}$.

2 National Library of Russia. Manuscript Department. F. 427. No. 1. 
Thus, Leykin's correspondence turned out to be divided arbitrarily, since all three archives contain letters from the same correspondents for different years. Among them, for the most part, is correspondence from writers and journalists A. V. Amfiteatrov, V. M. Garshin, I. I. GorbunovPosadov, V. R. Zotov, N. S. Leskov, D. N. Mamin-Sibiryak, V. O. Mikhnevich, V. I. Nemirovich-Danchenko, K. M. Stanyukovich, Alexandre P. and Anton P. Chekhovs, I. I. Yasinsky and others. Letters written by Leykin himself are scattered across many personal fonds and collections as part of the archival complexes of the addressees. Their exhaustive identification requires separate research. As for Leykin's memoirs, their original manuscript is obviously lost. It was not found either in the writer's archives or in the collection of the editorial board of the Istorichesky Vestnik and its editor S. N. Shubinsky. Unfortunately, we also do not know the fate of the rest volumes of the writer's diaries.

The fate of Leykin's archive and personal materials was fairly typical for his epoch. Popular during his lifetime, soon after his death, the writer was buried in oblivion. In the cataclysms of the first half of the $20^{\text {th }}$ century, Leykin's archive was dispersed and divided into three parts. By a lucky coincidence, many documents survived and entered in the state archives, but some of the diaries and handwritten memoirs have not yet been found. Study of the extant volumes of diaries allows us to talk about their uniqueness. In addition to their importance for the scientific community, the diaries will be of interest to a wide range of readers, since they recreate a picture of the life of the Russian society on the eve of fundamental changes in the life of the country.

\section{Список литературы}

Источники

Из переписки А. П. Чехова с Н. А. Лейкиным (неопубликованные письма) / подгот., вступ. ст. Г. Прохорова // Новый мир. 1940. № 1. С. 229-241; № 2-3. С. 379-395.

Лейкин Н. А. [Автобиографическая заметка 1883 г.] // Знакомые: Альбом М. И. Семевского: Книга автобиографических собственноручных заметок 850 лиц: Воспоминания. Стихотворения. Эпиграммы. Шутки. Подписи: 1867-1888. СПб.: Тип. В.С. Балашева, 1888. С. 202.

Лейкин Н. А. Автобиографическая заметка [1903 г.] // Беседа. 1903. № 6. Стб. 279-281.

Лейкин Н. А. Мои воспоминания // Исторический вестник. 1906. № 1. C. 152-180; № 2. С. 493-522; № 3. С. 849-882; № 4. С. 100-109. 
Лейкин Н. А. Мои воспоминания // История Петербурга. 2003. № 1. С. 8-13; № 2. С. $6-10$; № 3. С. 5-7; № 4. С. 30-35; № 5. C. 12-15; № 6. С. 11-16; 2004. № 1. С. 3-7; № 2 . C. 75-82; № 3. C. 3-9; № 4. C. 3-7.

Лейкин Н. А. Мои воспоминания // Петербургское купечество в XIX веке / вступ. ст., сост. и примеч. А. М. Конечного. СПб.: Гиперион, 2003. С. 121-256.

Николай Александрович Лейкин в его воспоминаниях и переписке. СПб.: Т-во Р. Голике и А. Вильборг, 1907. 387 с.

Соколов А. А. Из моих воспоминаний (театральных, литературных и общественных): Записки А. А. Соколова // Московский листок. Илл. прибавление. 1909. № 1. С. 2-5; № 2. С. 4-8; № 3. С. 3-7; № 4. C. 2-4; № 5. С. 2-4; № 6. С. 2-6; № 7. С. 2-5; № 8. C. 3-4; № 9. C. 2-5; № 10. C. 5-6; № 11. C. 2-4; № 13. C. 2-3; № 14. C. 2-8; № 15. C. $2-10$; № 16. C. 10-14; № 17. C. 14-16; № 18. C. 2-4; № 20. C. 2-5; № 21. C. 2-4; № 22. C. 2-4; № 23. С. 2-6; № 24. C. 2-7; № 26. C. 2-4; № 27. C. 2-8; № 28. C. 2-7; № 29. С. 2-4; № 30. C. 1-6; № 31. C. 2-6; № 32. С. 2-6; № 33. C. 7-11; № 34. C. 4-10; № 35. С. 10-15; № 36. С. 5-7; № 37. С. 5-11; № 38. С. 6-8; № 39. С. 10-14; № 41. C. 7-10; № 42. С. 5-9; № 43. С. 5-7; № 44. С. 5-7; № 46. C. $6-12$; № 47. С. 5-8; № 48. С. 5-8; № 49. С. 10-11; № 50. C. 3-6.

\section{Исследования}

Барышников М. Н. Деловой мир Петербурга: Исторический справочник. СПб.: Logos, 2000. 582 c.

Белоцерковская Н. И. А. П. Чехов в журнале «Осколки»: автореф. дис. ... канд. филол. наук. М., 1974. 23 с.

Гитович Н. И. [Вступительная статья] // Литературное наследство. М.: Изд-во АН СССР, 1960. Т. 68: Чехов / гл. ред. В. В. Виноградов. С. 499-500.

Катаев В. Б. Лейкин Николай Александрович // Русские писатели: 1800-1917. М.: Сов. энциклопедия, 1994. Т. 3: К-М. С. 308-310.

Катаев В. Б. Лейкинский вариант (из истории русской юмористики XIX в.) // Вестник МГУ. Сер. 9. Филология. 1981. № 1. С. 21-31.

Катаев В. Б. Чехов и его литературное окружение (80-е годы XIX века) // Спутники Чехова. М.: Изд-во МГУ, 1982. С. 17-24.

Морозова E. Н. Парадоксы водевильной традиции в «шуточных сценках» Н. А. Лейкина // Филоlogos. 2019. № 2 (41). С. 30-39.

Овчарская О. В. А. П. Чехов и Н. А. Лейкин: сходство, подчеркивающее различие // Филологические науки. Вопросы теории и практики. 2016. № 3-1 (57). C. 41-45.

Рейтблат А. И. Читательская аудитория // Книга в России, 1895-1917 / под общ. ред. И. И. Фроловой. СПб.: Российская нац. б-ка, 2008. С. 635-654.

Смирнова М. А. Мемуарные произведения Н. А. Лейкина: история создания и изучения // Историография и источниковедение истории России: Сб. науч. статей. СПб.: «Скифия-принт», 2011. Вып. 6. С. 261-276.

Тихомиров С. В. Лейкин Н. А. // Русские писатели: Биобиблиографический словарь / под ред. П. А. Николаева. М.: Просвещение, 1990. Т. 1: А-Л. С. 404-406. 
Чудаков А. [П.] Мир Чехова: Возникновение и утверждение. М.: Сов. писатель, $1986.379 \mathrm{c}$.

Чудаков А. П. «Осколки» // Краткая литературная энциклопедия / гл. ред. А. А. Сурков. М.: Сов. энциклопедия, 1968. Т. 5: Мурари - Припев. Стб. 482-483.

Швец,ова Л. К. Массовые еженедельники для «пестрого» читателя // Литературный процесс и русская журналистика конца XIX - начала XX века: 1890-1904: Буржуазно-либеральные и модернистские издания / отв. ред. Б. А. Бялик. М.: Наука, 1982. С. $275-297$.

Шиловских И. С. Его называли отцом русской сценки (О творчестве Н. А. Лейкина) // Литература в школе. 2000. № 5. С. 30-43.

Шиловских И. С. Жанровое своеобразие прозы и драматургии Н. А. Лейкина: дис. ... канд. филол. наук. М., 1999. 241 с.

\section{References}

Baryshnikov, M. N. Delovoi mir Peterburga: Istoricheskii spravochnik [Business World of St. Petersburg: Historical Reference Book]. St. Petersburg, Logos Publ., 2000. 582 p. (In Russ.)

Belotserkovskaia, N. I. A. P. Chekhov v zhurnale "Oskolki" [A. P. Chekhov in the Journal Oskolki: PhD Thesis, Summary]. Moscow, 1974. 23 p. (In Russ.)

Gitovich, N. I. "Vstupitel'naia stat'ia" ["Introductory Article"]. Literaturnoe nasledstvo [Literary Heritage], vol. 68. Moscow, USSR Academy of Sciences Publ., 1960, pp. 499-500. (In Russ.)

Kataiev, V. B. "Leikin Nikolai Aleksandrovich" ["Leykin Nikolay Aleksandrovich"]. Russkiie pisateli: 1800-1917 [Russian Writers: 1800-1917], vol. 3. Moscow, Soviet Encyclopedia Publ., 1994, pp. 308-310. (In Russ.)

Kataiev, V. B. "Leikinskii variant (iz istorii russkoi iumoristiki XIX v.)". ["Leykin's Version (From the History of Russian Humorism of the $19^{\text {th }}$ Century)"]. Vestnik Moskovskogo Universiteta, ser. 9. Philologie, no. 1, 1981, pp. 21-31. (In Russ.)

Kataiev, V. B. "Chekhov i ego literaturnoe okruzhenie (80-e gody XIX veka)." ["Chekhov and his Literary Surroundings (1880s)"]. Sputniki Chekhova [Companions of Chekhov]. Moscow, Moscow State University Publ., 1982, pp. 17-24. (In Russ.)

Morozova, E. N. "Paradoksy vodevil'noi traditsii v 'shutochnykh stsenkakh' N. A. Leikina" ["Paradoxes of Comic Sketch Tradition in 'Joking Scenes' by N. A. Leykin"]. Filologos, no. 2 (41), 2019, pp. 30-39. (In Russ.)

Ovcharskaia, O. V. "A. P. Chekhov i N. A. Leikin: skhodstvo, podcherkivaiushcheie razlichie" ["A. P. Chekhov and N. A. Leykin: Similarity, Emphasizing the Difference"]. Filologicheskie nauki. Voprosy teorii i praktiki, no. 3-1 (57), 2016, pp. 41-45. (In Russ.)

Reitblat, A. I. "Chitatel'skaia auditoriia" ["Reader Audience"]. Frolova, I. I., editor. Kniga v Rossii, 1895-1917 [Book in Russia, 1895-1917]. St. Petersburg, National Library of Russia Publ., 2008, pp. 635-654. (In Russ.)

Smirnova, M. A. "Memuarnye proizvedeniia N. A. Leikina: istoriia sozdaniia i izucheniia" ["Memoirs of N. A. Leykin: Origin and Studying"]. Istoriografiia $i$ 
istochnikovedenie istorii Rossii: Sb. nauch. statey [Historiography and Source Study of the History of Russia: A Collection of Scientific Articles], vol. 6. St. Petersburg, Skifiya-print Publ., 2011, pp. 261-276. (In Russ.)

Tikhomirov, S. V. "Leikin N. A.” ["Leykin N. A.”]. Nikolayev, P. A., editor. Russkie pisateli: Biobibliograficheskii slovar' [Russian Writers: Biobibliographical Dictionary], vol. 1. Moscow, Prosveshchenie Publ., 1990, pp. 404-406. (In Russ.)

Chudakov, A. [P.] Mir Chekhova: Vozniknovenie i utverzhdenie [The World of Chekhov: Emergence and Approval]. Moscow, Sovetskii pisatel’ Publ., 1986. 379 p. (In Russ.)

Chudakov, A. P. "Oskolki” [“Oskolki”]. Surkov, A. A., editor. Kratkaia literaturnaia entsiklopediia [Brief Literary Encyclopedia], vol. 5. Moscow, Soviet encyclopedia Publ., 1968, col. 482-483. (In Russ.)

Shvetsova, L. K. "Massovye ezhenedel'niki dlia 'pestrogo' chitatelia” ["Mass Weekly Journals for the 'Motley' Reader"]. Byalik, B. A., editor. Literaturnyi protsess i russkaia zhurnalistika kontsa XIX - nachala XX veka: 1890-1904: Burzhuazno-liberal'nye $i$ modernistskie izdaniia [Literary Process and Russian Journalism of the Late 19 - Early 20 Centuries: 1890-1904: Bourgeois-liberal and Modernist Publications]. Moscow, Nauka Publ., 1982, pp. 275-297. (In Russ.)

Shilovskikh, I. S. "Ego nazyvali ottsom russkoi stsenki (O tvorchestve N. A. Leikina)." ["He Was Called the Father of the Russian Sketch (On the Work of N. A. Leykin)."]. Literatura $v$ shkole, no. 5, 2000, pp. 30-43. (In Russ.)

Shilovskikh, I. S. Zhanrovoe svoeobrazie prozy i dramaturgii N. A. Leikina [Genre Originality of Prose and Drama of N. A. Leykin: PhD Thesis]. Moscow, 1999. 241 p. (In Russ.) 


\title{
Повесть И. Г. Шадрина «Бурса»: источники и прототипы
}

\begin{abstract}
Аннотация: Статья посвящена анализу повести Илария Шадрина «Бурса». Автор работы выявляет действительно имевшие место исторические обстоятельства и фактически верные описания лиц, служивших прототипами героев повести. Исходя из текста художественного произведения, с привлечением широкого круга дополнительных, в том числе архивных источников, реконструируется картина повседневной жизни Вологодской семинарии, намечаются биографические портреты преподавателей и учащихся. Автор статьи отмечает, что художественные образы, созданные Иларием Шадриным, не являются исторически точными портретами и объективными характеристиками реальных персон. Констатируется, что повесть «Бурса» содержит мало точных указаний на даты. Ее несомненная ценность заключается в россыпи наблюдений, подробностей, бытовых деталей, которые были уловлены и запечатлены автором. Именно конкретные живые зарисовки, а не публицистические полемические аргументы составляют главную ценность произведения Илария Шадрина. Аналитическое изучение художественного мира повести и других источников позволяет автору статьи сделать вывод о том, что писатель был излишне погружен в собственные переживания, в обдумывание обстоятельств и роли в них его собственной персоны.

Ключевые слова: Иларий Шадрин, Вологодская семинария, бурса, духовенство, Вологодская епархия, прототип, литературный герой, правдоподобие, творческая история, авторская позиция.
\end{abstract}

Информация об авторе: Николай Викторович Солодов, кандидат физико-математических наук, старший преподаватель кафедры церковно-практических дисциплин, Московская духовная академия, Троице-Сергиева Лавра, 141300 г. Сергиев Посад, Московская область, Россия.

E-mail: nsolodov@gmail.com

Дата поступления статьи в редакиию: 02.06 .2021

Дата одобрения статьи рецензентами: 13.08 .2021

Дата публикации статьи: 30.09.2021

Для цитирования: Солодов Н. В. Повесть И. Г. Шадрина «Бурса»: источники и прототипы // Два века русской классики. 2021. Т. 3, № 3. С. 172-189. https://doi.org/ 10.22455/2686-7494-2021-3-3-172-189 


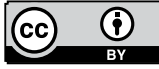

This is an open access article distributed under the Creative Commons Attribution 4.0 International (CC BY 4.0)
Dva veka russkoi klassiki, vol. 3, no. 3, 2021, pp. 172-189. ISSN 2686-7494

Two centuries of the Russian classics, vol. 3, no. 3, 2021, pp. 172-189. ISSN 2686-7494

Research Article
(C) 2021. Nikolay V. Solodov (Priest Nikolay Solodov) Moscow Theological Academy Sergiev Posad, Russia

\title{
The Story Bursa by I. G. Shadrin: Sources and Prototypes
}

\begin{abstract}
The article is devoted to the analysis of the story Bursa by Ilariy Shadrin. The author reveals historical circumstances that actually took place and true descriptions of the persons who served as prototypes of the story heroes. Based on the text, involving a wide range of additional sources, including archival, the picture of the daily life of the Vologda Seminary is reconstructed, biographical portraits of teachers and students are outlined. The author notes that the artistic images created by Ilariy Shadrin are not historically accurate portraits and objective characteristics of real persons. It is stated that the story "Bursa" contains few precise indications of the dates. Its undoubted value lies in the scattering of observations, particulars, everyday details captured by the author. It is concrete living sketches, not journalistic polemical arguments, that constitute the main value of Ilariy Shadrin's work. An analytical study of the artistic world of the story and other sources allows the author to conclude that the writer was excessively immersed in his own experiences, in thinking over the circumstances and the role of his own person in them.

Keywords: Ilariy Shadrin, Vologda seminary, bursa, clergy, Vologda diocese, prototype, literary hero, credibility, creative history, author's position.
\end{abstract}

Information about the author: Nikolai V. Solodov, $\mathrm{PhD}$ of Physics and Mathematics, Senior Lecturer of the Department of Church Practical Disciplines, Moscow Theological Academy, Trinity-Sergius Lavra, 141300 Sergiev Posad, Moscow Region, Russia.

E-mail: nsolodov@gmail.com

Received: June 02, 2021

Approved after reviewing: August 13, 2021

Published: September 30, 2021

For citation: Solodov, N. V. "The Story Bursa by I. G. Shadrin: Sources and Prototypes." Dva veka russkoi klassiki, vol. 3, no. 3, 2021, pp. 172-189. (In Russ.) https://doi. org/10.22455/2686-7494-2021-3-3-172-189 
Имя писателя Илария Григорьевича Шадрина (1872-1934) сейчас мало известно. Сведения о нем отсутствуют в энциклопедиях. Нет ни одного специального исследования, посвященного его жизни и творчеству.

Архивные материалы о Шадрине попадали в поле зрения исследователей. На их основе подготовлена биобиблиографическая статья Д. С. Глебовой для завершающего тома (Ш-Я) словаря «Русские писатели. 1800-1917». Обстоятельные выписки из повести Шадрина «Бурса» сделаны ранее митрополитом Иларионом (Алфеевым) для очерка, посвященного проблемам духовного образования [Иларион]; они послужили иллюстрацией общих процессов, происходивших в русских семинариях конца XIX - начала XX вв.

Несомненная ценность повести «Бурса» заключается в художественно точном описании обучения в Вологодской духовной семинарии и отчасти жизни духовенства Вологодской епархии 1890-1900-х гг. Историческую картину воссоздают бытовые и портретные зарисовки Шадрина, подмечавшего такие подробности, которые редко обнаруживаются в официальных документах или мемуарах.

Узнаваемость образов повести «Бурса» и описанных событий приводила к тому, что современники ошибочно принимали художественный текст за исторический источник. Сопоставление повести с выявленными архивными документами дает возможность наблюдать результаты творческой работы Шадрина с материалами его жизненных наблюдений, а также увидеть дистанцию, разделяющую в творческой лаборатории писателя прототип и художественный образ.

Сведения о прототипах персонажей повести «Бурса» и об истории Вологодской духовной семинарии были обнаружены в Российском государственном архиве литературы и искусства (РГАЛИ) и Государственном архиве Вологодской области (ГАВО). 
Н. В. Солодов (Иерей Николай Солодов). Повесть И. Г. Шадрина «Бурса» ...

Черновики и дневниковые записи Шадрина хранятся в фонде писателя в РГАЛИ. Объемный Дневник ${ }^{1}$ (348 л.) содержит, кроме собственно дневниковых записей, черновики и наброски. По всей видимости, с самого начала предполагалась возможность его прочтения посторонними. На страницах встречаются пометы и записи предположительно брата Шадрина.

Официальные документы Вологодской семинарии сохраняются в ГАВО. Журналы педагогических собраний, рапорты инспектора о поведении воспитанников, сведения об учащихся - это ценные источники для анализа творческой истории повести Шадрина.

«Епархиальные ведомости» являются малоизученным и при этом богатейшим источником по истории России и Русской Православной Церкви второй половины XIX в. Не исключение «Вологодские епархиальные ведомости», печатавшие на своих страницах отчеты о товарищеских съездах выпускников Вологодской семинарии 1894 г. Организаторами таких встреч были однокурсники Шадрина - активные выпускники И. С. Бачалдин, Н. Н. Следников (впоследствии епископ Неофит), священник кафедрального собора о. Михаил Поддьяков, Н. В. Соловьев; они поддерживали связь с однокашниками и писали о состоявшихся встречах [Бачалдин; Следников].

В Куженерском историко-краеведческом музее (Республика Марий Эл) обнаружена фотография выпускников 1894 г., сделанная во время первого съезда (1904), с подписями на обороте. Этот фотодокумент дает представление о том, как выглядели многие семинаристы, описанные в повести «Бурса», насколько художественное описание совпадает с внешностью прототипа.

Сохранились и мемуары современников о Вологодской семинарии и Вологодской епархии. К наиболее подробным, взвешенным и информативным относятся воспоминания Никифора Александровича Ильинского «Из далекого прошлого», электронная копия которых находится в Вологодском архиве ${ }^{2}$. Воспоминания Бориса Вячеславовича и о. Вячеслава Александровича Ильинских были любезно предоставлены нам О. Б. Ушаковой, внучкой В. А. Ильинского. В этом же ряду следует указать воспоминания А. А. Турундаевского «Наша семья» [История: 191-355]. Отдельно назовем статью обновленческого прото-

\footnotetext{
1 РГАЛИ Ф. 556. ОП. 1. Д. 80.

2 ГАВО Ф. Р-5250. ОП. 1. Д. 1-2.
} 


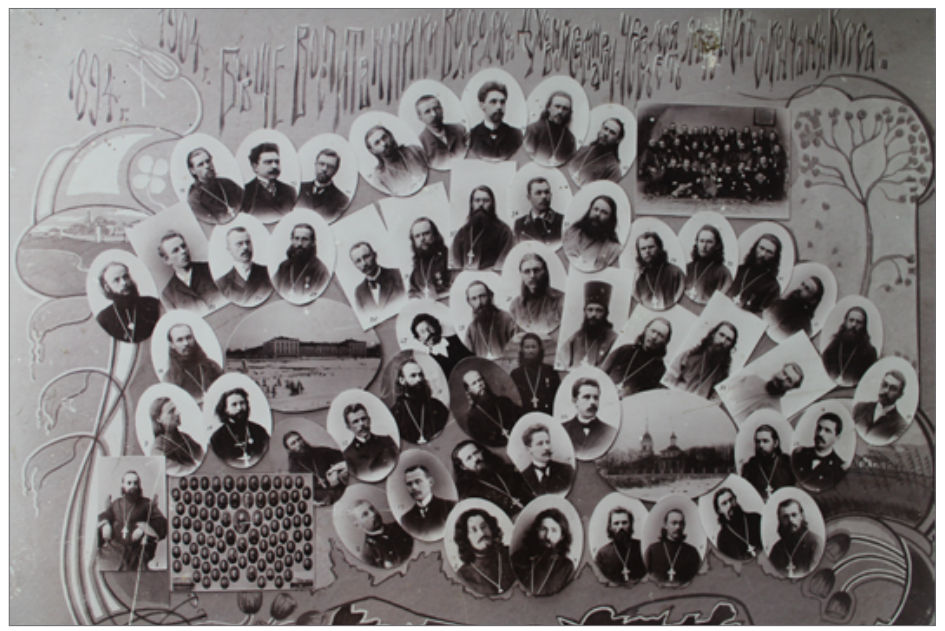

Фотография выпускников Вологодской семинарии 1894 г., сделанная в 1904 г. Хранится в Куженерском историко-краеведческом музее (Республика Марий Эл) ${ }^{1}$.

иерея Тихона Шаламова (отца писателя В. Шаламова) «Наши иерархи» с воспоминаниями о прошлом в газете Церковная заря 1922 г. [Шаламов]. В ней немного новых деталей, но пафос обличения и отрицания старых порядков удивительно напоминает повесть Шадрина.

Рецензию о повести Шадрина «Бурса» опубликовал в 1914 г. Е. А. Бурцев, озаглавив ее «Книга жалкой мести» [Бурцев]. Опровергая художественное изображение, автор рецензии избрал довольно уязвимую позицию, обратившись к подробному сравнению действительных обстоятельств жизни Вологодской семинарии с описанными в повести Шадрина.

Творческая история повести «Бурса» относится к рубежу веков. По словам Шадрина, написана она была в 1905 г. «в бытность в военной службе» [Бачалдин: 26], но первые наброски к повести есть уже в дневнике за 1897 г., а отдельные рассказы, вошедшие позднее в текст «Бурсы», Шадрин начал писать еще на четвертом курсе семинарии. Публиковалась повесть фрагментами в журнале «Красный звон» в 19081909 гг., а в 1913 и 1917 гг. вышла отдельными изданиями.

\footnotetext{
1 Автор статьи и редакция журнала благодарят директора Куженерского историко-краеведческого музея Т. В. Огородникову за предоставленные копии фотографий.
} 
Структурно повесть представляет серию очерков - не всегда выделенных отдельными заголовками, но отличающихся сюжетом и стилистикой: детство дьяконского сына в деревне, пьяные бесчинства отца, бедность и бесправие, особенно беспросветные для дьяконских дочерей; первые впечатления от бурсы, преподавателей и учебного процесса; отдельные зарисовки: каникулы, экзамены, карцер, первая любовь, кутежи, сватовство, семинарские беспорядки... Объединяет очерки образ повествователя - Гриши Никольского, столь же мечтательного и погруженного в свои переживания, как и сам Иларий Шадрин.

В повести преобладает критика семинарской и церковно-административной системы, калечащей живые души своих воспитанников. «Ни разу: за все шесть лет семинарской жизни, ученики не припомнят случая, чтобы к ним проявили хоть показное, хоть слабое участие, чтобы хотя одним случаем признали в них личность и равноправие» [Шадрин 1917: 200]. В составе семинарской инспекции нет «ни одного, который хотя немного походил бы на воспитателя. Все какие-то урядники...» [Шадрин 1917: 271]. «В современной бурсе я не нашел ярких, интересных образов, не нашел крупных личностей, - пишет Шадрин, - жизнь семинариста-бурсака проходит в зубрении до отупения и в пьянстве». И как вывод: «Измените условия его жизни, дайте ему побольше свободы и света... и вы увидите яркие образы и крупные характеры» [Шадрин 1917: 368].

Отмечая субъективность этих крайне тенденциозных оценок, Е. А. Бурцев возражал автору повести: «За самыми незначительными исключениями учителя семинарии были люди совершенно трезвые и в высокой степени трудолюбивые» [Бурцев: 130]. Добавим, что и товарищи Шадрина по семинарии были вполне яркими и одаренными людьми. Несомненно, что художественное преломление реальных впечатлений Шадрина в повести «Бурса» происходило под влиянием, во-первых, собственного негативного эмоционального фона, во-вторых, сложившейся литературной традиции, отдававшей предпочтение социальной сатире.

Ближайший литературный контекст «Бурсы» Шадрина сформировался под влиянием «Очерков бурсы» Н. Г. Помяловского. Написанные много раньше они были перед глазами всех последующих писателейсеминаристов. Сознательно или бессознательно реальность и воспоминания сравнивались с «классическим» образцом. Это отразилось в 
названиях: «Бурса» И. Г. Шадрина (1913), «Новая бурса» Л. М. Добронравова (1913), «Семинарские очерки» С. М. Беляева (1906), «Из быта новейшей бурсы» А. П. Куркина (1910), «В бурсе» А. А. Измайлова (1903), «Бурса» А. Воронского (1933), «Записки семинариста» Н. Румянцева (1906). Во всех этих попытках осмысления своего духовноучебного опыта присутствует сатирическое обличение, болезненное противостояние личности и «системы», недовольство формализмом «воспитателей»-надзирателей, вольнодумство или даже бунтарство. Книга Шадрина выделяется из этой череды, пожалуй, лишь тотальным отрицанием каких-либо достоинств семинарского обучения и большей погруженностью автора в свой собственный мир.

Помимо наиболее заметной «обличительной» линии «Бурсы», описанная в повести Шадрина жизнь семинариста представлена живой и разносторонней. Есть упоминания о серьезном образовании, основательных знаниях, о талантливых и творческих педагогах, широком круге чтения (в том числе, и даже особенно книг, запрещенных цензурой). Были в бурсе, как оказывается, и свои святые и праведники, конечно, незаметные и до времени неизвестные.

Несмотря на авторскую оговорку, что он делал «попытку... дать типы, обобщить жизнь духовной школы» и «местами включал многое, не бывшее в наше время в семинарии» [Бачалдин: 26], реальным источником повести «Бурса» следует считать историю Вологодской семинарии.

Портретная галерея преподавателей семинарии представлена в повести глазами ученика, своевольного и не особенно старательного. Иные характеристики находим в замечательных воспоминаниях многолетнего помощника инспектора Вологодской семинарии Н. А. Ильинского «Из далекого прошлого». Это взгляд администратора, добросовестного и честного.

Учитель церковной истории описан Шадриным как «мрачный, высокий и совершенно лысый господин, с грубым крикливым голосом, подозрительными, недружелюбными глазами, которые, казалось, никогда не смеялись» [Шадрин 1917: 38], как «строгий формалист, не знающий никакой жалости» [Шадрин 1917: 333]. Таким под пером Шадрина стал Евлампий Арсеньевич Бурцев (1858-1924) - многолетний преподаватель Архангельской и Вологодской семинарии, смотритель Никольского и Оренбургского духовных училищ, один из организа- 
торов Великоустюжского краеведческого музея и автор статьи «Книга жалкой мести», в которой защищает своих коллег и себя от незаслуженно резких оценок. В воспоминаниях Н. А. Ильинского сохранилось описание Бурцева как «человека прямого, замкнутого в себя и вообще скупого на похвалы» ${ }^{1}$

Портрет учителя философии и психологии Василия Васильевича Смелкова дается в повести Шадрина в обрамлении художественных деталей, передающих особенности его характера: «Строгий педант, аккуратный, затянутый, как барышня на балу, точный до смешного. Объяснение начинал он всегда непременно одною и той же фразой: “В прошлый раз я говорил вам". Но забавнее всего была его манера застегивать сюртук. Здесь он допускал некоторое разнообразие, но не случайное, а в строгом порядке следующее одно за другим. Если в понедельник сюртук его был застегнут на две верхние пуговицы правого борта, то завтра обязательно будет наоборот, послезавтра опять на две пуговицы правого борта и т. д. Если же все пуговицы застегнуты - это значило: жди беды, значит господин философ не в духе. Но всего хуже было то, что он прекрасно знал все уловки учеников и жестоко пользовался своим оружием. Зная, что даже лучшие ученики не прочь иногда полукавить, он “подсиживал”, т. е. на следующий урок, или еще через урок, снова спрашивал ответившего и торжественно ставил ему единицу, так как только что спрошенный, конечно, не знал урока» [Шадрин 1917: 66-67]. Воспоминания о Смелкове Ильинского сообщают, что он был выпускником Вологодской семинарии (1876) и Петербургской духовной академии (1882), «отличался скромностью и пунктуальной служебной аккуратностью. Оставил службу в семинарии в 1895 г., за назначением его на должность епархиального наблюдателя церковных школ. С упразднением этой должности был определен кафедральным протоиереем и на этом посту скончался 29 февраля 1920 г.»².

Очевидным прототипом учителя нравственного богословия и догматики в повести «Бурса» Василия Карповича был Василий Стефанович Карпов (1850-1913), многолетний преподаватель богословия и еврейского языка, с 1894 г. священник, протоиерей, настоятель Спа-

${ }^{1}$ Ильинский Н. А. Из далекого прошлого. ГАВО Ф. Р-5250. Оп. 1. Д. 1. Л. 294.

2 Там же. Л. 387-387 об. 
совсеградского собора. В воспоминаниях Ильинского он представлен «общим любимцем учеников. Всегда деликатный, предупредительный и вежливый. $<\ldots>$ в то же время был крайне снисходителен ко многим ученическим слабостям» ${ }^{1}$.

Шадрин критикует непоследовательность преподавателя богословия и представляет его прячущимся за внешние авторитеты при неудобных вопросах семинаристов. Однако и по тексту «Бурсы», и по дневникам Шадрина видно, насколько сильно задевали семинаристов вопросы, ставившиеся именно на богословских предметах, тем самым волей-неволей свидетельствуется педагогический талант В. С. Карпова. А солидарный с Шадриным в отвержении старого семинарского обучения Тихон Шаламов даже комплиментарно отзывался о В. С. Карпове, называя его самым передовым среди преподавателей [Шаламов: 5].

В повести «Бурса» изображены также преподаватели греческого языка Мухоморович (Александр Никанорович Макарьин) и Картошка (Константин Павлович Заболотский), учитель гомилетики КоляЛапоть (Николай Иванович Малиновский) и др.

Впрочем, настоящую боевую семью для семинариста составляют не преподаватели - они только снаружи, извне; даже самые симпатичные преподаватели все-таки воспринимаются с недоверием. Ближние семинариста - его одноклассники. Все встречающиеся в повести «Бурса» персонажи имеют своими прототипами учеников второго отделения семинарии, в котором учился Шадрин.

Прототипом заметного героя повести Ивана Ивановича Смилева стал Иван Иванович Смелков - хулиган и последний в списке ученик в классе. Удалось установить основные контуры его биографии. Родился при Летской церкви Усть-Сысольского уезда Вологодской епархии; по окончании семинарии с 1894 г. учительствовал в образцовой школы г. Сольвычегодска; с 1896 г. служил псаломщиком Иртовской Воскресенской церкви Яренского уезда; с 1899 г. - священник Онежской Богородской церкви того же уезда; в 1904 г. был перемещен к Преображенской Сойгинской церкви Сольвычегодского уезда, а в 1908 г. по судебному решению епархиального начальства отрешен от места с определением на причетническую должность. Не удалось выяснить, в чем была вина о. Иоанна, но можно предположить, что и в священни-

Там же. Л. 93 об. 
Н. В. Солодов (Иерей Николай Солодов). Повесть И. Г. Шадрина «Бурса» ...

ческом сане он не остепенился. В 1908 г. определен на место псаломщика при Вожемско-Цилибской церкви Яренского уезда [Православные приходы]; в 1914 г. - священник Знаменской Верхне-Уфтюжской церкви г. Тотьмы [Бачалдин: 37].

Ученик Сибиряков в повести «Бурса» был одним из приятелей Гриши Никольского по кутежам. В этом образе угадывается Владимир Васильевич Сибирцев. Он родился, как и Шадрин, в 1872 г., происходил из крестьян, проживал в с. Георгиевское Свердловского района Вологодского округа Северного края, где служил священником в Георгиевской церкви. 22 декабря 1930 г. был арестован по обвинению в «контрреволюционной агитации» как священник и расстрелян 11 июня 1931 г. [За веру Христову: 505].

В колоритной фигуре шадринской «Бурсы» Варуха (Еремина) легко просматривается личность ученика Константина Гаврииловича Еремиевского. Как удалось установить, к 1914 г. он успел овдоветь, был священником Туровецкой Богоявленской церкви Устюжского уезда [Бачалдин: 15]. Написал воспоминания о помощнике инспектора А. Д. Брянцеве «Добрая память о добром старце» [Еремиевский: 440], опубликованные, как и другие статьи этого автора, в «Вологодских епархиальных ведомостях».

В образе Николая Сопилова, «первого силача в классе», нетрудно угадать Николая Васильевича Соловьева (1874-1922). Дальнейшее образование Соловьев продолжил на медицинском факультете Томского университета, но был исключен за участие в студенческих волнениях. Доучившись в Юрьевском университете, с 1902 г. начал трудиться в Ярославской земской губернской больнице. «С 1914 г. заведующий специализированным хирургическим лазаретом. Впоследствии главный врач больницы, которой присвоено его имя» [Беляев: 20; Колодин: 307-313]. Идентификация прототипа подтверждается дневниковой записью Шадрина, параллельной описанию потасовки Сопилова и Куприна в начале повести «Бурса» ${ }^{1}$.

Еще один одноклассник Шадрина - Михаил Александрович Образцов - также пошел по медицинской стезе. В повести «Бурса» он изображен как Мишка Кот. А. Турундаевский позднее воспоминал: «Многие семинаристы не пошли дорогой своих предков. Одним из них был друг дяди Саши (Александра Васильевича Турундаевского)

${ }^{1}$ РГАЛИ Ф. 556. Оп. 1. Д. 80. Л. 3-4. 
Михаил Левицкий. В книге “Бурса” Иларий Шадрин называет его Миша Кот. После семинарии Левицкий окончил университет по медицинскому факультету и до глубокой старости работал в Вологде врачом-терапевтом. Он в числе первых встал "на платформу советской власти”, тогда как многие старые врачи царского времени задумывались, как принять новую власть. Мог душевно беседовать, успокаивающе действовать на пациента. Умер врач Левицкий в 1965 году» [История: 280]. В этих воспоминаниях перепутаны имена. Мишка Кот в «Бурсе» учится вместе с Гришей в одном классе до окончания семинарии. Фамилия Левицкий, однако, вовсе не значится среди выпускников Вологодской семинарии. Есть Левитские. Но в сколько-нибудь близкие годы Михаила Левитского нет. В классе Илария Шадрина было четыре Михаила: Образцов, Панебратцев, Волокитин и Поддьяков. Двое последних приняли священный сан. Панебратцев стал преподавателем в женской гимназии; Образцов - врачом в Якутске. На сайте Якутского медицинского колледжа написано, что директором Якутской фельдшерской школы с 1909 по 1914 гг. был Михаил Александрович Образцов. Вполне возможно, что после 1914 г. он вернулся в Вологду.

О прототипе Миши Пантюхина можно говорить с определенной долей уверенности. Это Михаил Михайлович Панебратцев. Помимо совпадения имени и первой буквы фамилии, есть еще несколько аргументов в пользу этой идентификации. Пантюхин представлен как один из авторов семинарского журнала «Опыты», а в дневниках Шадрина в числе немногих учеников, писавших для журнала, указан Панебратцев. Его увлечение словесностью прослеживается и в последующие годы: учился в Нежинском историко-филологическом институте, в 1914 г. преподавал в женской гимназии в г. Ромнах Полтавской губернии [Бачалдин: 36], автор «Методической грамматики русского языка для средних учебных заведений и самообразования». О нем говорится в одном из писем В. Г. Короленко к И. Ф. Анненскому от 10 мая 1907 г.: «Михаил Михайлович Панебратцев - тот самый полтавский учитель, о котором я уже Вам говорил. Основа его злоключений: Киевский округ хотел перевести его в Умань. Он уперся. Тогда округ, осердившись, не утвердил его учителем даже в частной гимназии. Итак - для Умани годится, для частного уч<ебного> заведения не годится! Буду глубоко признателен, если Вы окажете ему внимание и дадите руководящие в лабиринте ведомства советы» [Анненский: 409]. 
Несколько приниженным изображается в повести «Бурса» одноклассник Гриши Никольского - Петька (в некоторых местах непоследовательно Дмитрий Павлович): Куприн, Крыса, «толстый, щетинистый и курносый бурсак». Прототипом этого образа был Дмитрий Константинович Куклин. Его послужной список включает обязанности псаломщика Сольвычегодской Борисоглебской церкви Вологодской епархии (1895), псаломщика Жешартской Спасской церкви Яренского уезда (1896), священника Благовещенской Ербуговской церкви Вологодского уезда (1899), Стефановской кладбищенской церкви г. Устюга (1912) [Православные приходы]. С начала 1931 г. начались аресты и ссылки - в Коми, в Казахстане. За «проведение нелегальных сборищ» и "распространение антисоветской агитации против колхозного строя» иерей Д. К. Куклин был расстрелян. Его имя включено в Собор новомучеников и исповедников Российских постановлением Синода от 27 декабря 2000 г.

Система образов повести «Бурса», помимо преподавателей и учащихся, включает администрацию учебного заведения. В жизни семинаристов инспекция занимала уникальное место. Если преподаватели - это внешние наблюдатели, иногда досадные препятствия, но в общем и целом чужеродные явления, то администрация: ректор и особенно инспектор и помощники инспектора - это противники, враги, которые либо побеждают, либо повержены.

Образ ректора, его напутственное слово выпускникам, воссозданные Шадриным в повести, приближены к историческому портрету о. Иоанна Лебедева. Посвященные ему строки проникнуты особым чувством: «На амвон вышел ректор и начал свое прощальное слово. Он был тоже взволнован. Его выразительное лицо было грустно... Он густо крякнул, поправил свою львиную гриву на львиной голове и начал речь низким, прерывающимся голосом. Отрывисто, с одышкой говорил он, но говорил веско, с чувством. Не длинна была речь и не блистала перлами риторического красноречия, и не радости жизни сулила она слушателям, но добралась до самого сердца и на глаза многих вызвала слезы. “В мире скорбни будете”, - начал он напутственными словами Христа ученикам. Далее он ярко обрисовал незавидную и трудовую долю сельского священника со всеми ее темными сторонами, искушениями и невзгодами. “Но мужайтесь, яко аз победил мир”, - утешал и ободрял он слу- 
шателей словами Великого Учителя... Семинаристы слушали, затаив дыхание...» [Шадрин 1917: 359-360]. Воспоминания Шадрина об о. Иоанне были опубликованы в «Вологодских епархиальных ведомостях» [Шадрин 1896].

Менее лестные упоминания о «ректоре-корове», монахе, по слухам состоящем в конкубинате, относятся к ректору архимандриту Василию (Лузину), занимавшему эту должность после, с августа 1895 г. по ноябрь 1896 г. Этот художественный образ повести «Бурса» также максимально приближен к историческому портрету. О. Василий был из вдовых священников, племянник известного толкователя Евангелия Михаила (Лузина). По ряду причин он не смог стать хорошим администратором, и через год после назначения «атмосфера для архимандрита Василия как в семинарии, так и в городе создалась неблагоприятная» ${ }^{1}$. Он был перемещен на должность настоятеля Арзамасского Спасо-Преображенского монастыря.

Исключительно темными красками нарисован в повести «Бурса» образ инспектора Петра Успенского, прозванного Плакидой и бывшего главным источником неприятностей учащихся, - «низенького, толстобрюхого попика, с масляною физиономией, гладко причесанными, точно всегда смоченными, льняного цвета волосами, с мягким, ровным голосом $<\ldots>$ было что-то в о. инспекторе притворно-плаксивое, кислое» [Шадрин: 42]. И далее инспектору достается от автора и за нудные наставления, и за напыщенные проповеди, и за принудительное благочестие.

Насколько соответствуют зарисовки Шадрина реальному образу о. Петра, показывают документальные источники. Петр Иванович Успенский (1859-1936) был сыном священника Тверской епархии; закончил Тверскую семинарию (1879) и Санкт-Петербугскую духовную академию (1883). Преподавал Св. Писание в Вологодской семинарии. В 1885 г. его рукоположили во священники Вологодского кафедрального Софийского собора; затем последовало назначение инспектором Вологодской семинарии. В этой должности находился до начала 1897 г., когда был переведен преподавателем в Тамбовскую семинарию, где прослужил до 1908 г. Состоял членом Тамбовской духовной консисто-

${ }^{1}$ Ильинский Н. А. Из далекого прошлого. ГАВО Ф. Р-5250. Оп. 1. Д. 1. Л. 261. 
рии. Некоторое время был обновленческим епископом Орла и Тамбова, сохраняя в монашестве имя Петр ${ }^{1}$.

В оценке о. Петра солидарен с Шадриным Тихон Шаламов, писавший в 1922 г.: «Воспитателем юношества, инспектором, был отвратительный ханжа и лицемер, священник Петр Успенский, по прозвищу Плакида. Казалось, он нарочно поставлен был для того, чтобы вытравить последнее религиозное чувство в своих учениках» [Шаламов: 6].

Более спокойной и объективной оценки придерживался Н. А. Ильинский: «Небольшого роста, в то время тощий - своей фигурой он не производил выгодного впечатления. Преподавание он вел довольно вяло, говорил гнусаво. Уже и в то время у Петра Ивановича замечалась склонность делать ученикам, иногда по пустому случаю, нотации и читать морали, что учеников, особенно старших классов, всегда раздражало. Как инспектор, он применил свою манеру к нравоучительным беседам в самом широком масштабе. Ученики терпеливые и по характеру добродушные к таким воспитательным приемам П. Ив-ча относились или добродушно, или безразлично, но на юнцов невыдержанных, с характером неуравновешенным они действовали раздражающе и вызывали ропот и неудовольствие» ${ }^{2}$. Вместе с тем Ильинский отмечает многие достоинства о. Петра: «С первых же шагов его деятельности можно было видеть, что о. Петр был замечательно трудоспособный человек. Постоянно он был за делом, усердно следил за учениками как в корпусе семинарии, так и на квартирах. На все он старался обращать внимание и делать изменения или дополнения в распорядках жизни учеников»³. К положительным оценкам присоединил свой голос преподаватель семинарии В. К. Лебедев, резюмировав административный путь о. Петра: «Инспектор Успенский очень ревностно исполнял свои обязанности, но ученики почему-то недолюбливали его и после одной неприятной истории (ученики побили одного семинариста, подозревая в шпионстве инспектору) по

ГАВО Ф. 466. Оп. 2. Д. 20. Формулярный список прот. П. Успенского. Л. 1 об. -8.

${ }^{2}$ Ильинский Н. А. Из далекого прошлого. ГАВО Ф. Р-5250. Оп. 1. Д. 1. Л. 201 об. -202.

${ }^{3}$ Там же. Л. 202 об. 
донесению Еп. Алексея он был переведен на должность преподавателя в Тамбовскую семинарию» ${ }^{1}$.

Состав Вологодской семинарской администрации менялся. Неприятных служителей терпели, в отдельных выдающихся случаях жаловались или бунтовали. Но подлинное воспитание держалась на немногих подвижниках духовно-учебного ведомства. Несмотря на свой априорный принцип тотальной критики и отвержения старых порядков, Шадрин, как добросовестный, хотя и мечтательный наблюдатель, этого скрыть не мог.

Многолетний помощник инспектора Аркадий Досифеевич Брянцев [Еремиевский; Кремлевский], имевший прозвище Папаша, выведен в повести «Бурса» в тональности сердечного расположения и благодарности. Не одно поколение вологодских семинаристов связывали свои лучшие воспоминания о семинарских порядках с этим, занимавшим незначительную должность, человеком. Уважением пронизаны описания и другого помощника инспектора - Никифора Александровича Ильинского. Предположительно его изобразил Шадрин в «Бурсе» под именем Тимофея Александровича, Тимохи.

Восхищенного отзыва Шадрина в «Бурсе» удостоился только один инспектор: «Эх, братцы, вот Амфилохий был инспектором - не житье, а масленица была. Тут о бунтах и разговору не было. И ректор тогда был хороший... Жаль одного - были они с Амфилохием недолго, показались и ушли» [Шадрин 1917: 235]. Под именем Амфилохия выведен иеромонах Феофан (Василий Васильевич Харитонов; 1869-1937), служивший инспектором Вологодской семинарии в 1897-1901 гг. Уже тогда строгий подвижник и истинный монах, уволившись из семинарии, он уехал на Афон, где подвизался до смерти. В конце жизни был духовником русских насельников Карули и весьма почитаемым старцем. Несмотря на согласное мнение современников, что для должности инспектора о. Феофан не годился, воспоминания о его деятельности остались исключительно светлые, как у воспитанников, так и у сослуживцев. То, что под именем Амфилохия Шадрин изобразил о. Феофана (Харитонова), подтверждается описанным в повести «Бурса» похищением штрафной книги, известным по воспоминаниям Ильинского и по официальному донесению в Журнале педагогических собраний.

1 Вологодский государственный историко-архитектурный и художественный музей-заповедник. Ф. 15. Оп. 1. Д. 7. Л. 253 об. 
Повесть И. Г. Шадрина «Бурса», сохранившиеся дневники писателя ${ }^{1}$, его ранние рассказы, как изданные [Шадрин 1914], так и оставшиеся в рукописях ${ }^{2}$, составляют литературное наследие писателя, автобиографическая основа которого включает опыт и впечатления лет, проведенных в стенах Вологодского духовного училища и семинарии. Эта приближенность художественного повествования к документальности дает основание рассматривать повесть «Бурса» как один из источников при изучении истории Вологодской семинарии.

Между тем художественные образы, созданные Шадриным, не являются исторически точными портретами и объективными характеристиками реальных персон. В повести «Бурса» мало точных указаний на даты. Ее несомненная ценность заключается в россыпи наблюдений, подробностей, бытовых деталей, которые были уловлены и запечатлены автором. Именно конкретные живые зарисовки, а не публицистические полемические аргументы составляют главную ценность «Бурсы».

Наконец, следует отметить, что И. Г. Шадрин был излишне погружен в собственные переживания, так что присущий автору эгоцентризм, обдумывание своих обстоятельств и роли в них его собственной персоны занимает весьма значительное место как в дневниках, так и в художественных произведениях.

1 РГАЛИ Ф. 556. Оп. 1. Ед. хр. 80 и др.

2 РГАЛИ Ф. 556. Оп. 1. Ед. хр. 12 и др. 


\section{Список литературы \\ Источники}

Анненский И. Ф. Письма: в 2 т. / сост. и коммент. А. И. Червякова. СПб.: Изд-во им. Н. И. Новикова, 2007. Т. 1: 1879-1905. 449 с.

Бачалдин И. С. Второй товарищеский съезд бывших воспитанников Вологодской духовной семинарии 1894 г. выпуска. Вологда: Тип. Губернского правления, 1915. $38 \mathrm{c}$.

Еремиевский К. Добрая память о добром старце [Аркадии Досифеевиче Брянцеве]: (Из воспоминаний бывшего семинариста) // Вологодские епархиальные ведомости. 1908. № 19. С. 439-440.

За веру Христову. Духовенство, монашествующие и миряне Русской православной церкви, репрессированные в Северном крае (1918-1951): биографический справочник / сост. С. В. Суворова; Архангел. и Холмогор. епархия. Архангельск: Православ. издат. центр, 2006. 683 с.

Иларион (Алфеев Г. В.). Православное богословие на рубеже столетий: статьи, доклады. М.: Крутиц. Патриаршее Подворье, 1999. 426 с.

История от первого лица: мир северной деревни начала XX века в письменных свидетельствах сельских жителей / сост., науч. ред. В. Н. Матонин. Архангельск; М.: Т-во Северного Мореходства, 2011. 359 с.

Кремлевский А. М. Аркадий Досифеевич // Странник. 1901. № 5. С. 800-817.

Православные приходы и монастыри Севера. URL: http://parishes.mrezha.ru/ (дата обращения: 23.03.2021).

Следников Н. Н. Товарищеский съезд питомцев духовной семинарии, через 10 лет после окончания ими курса // Вологодские епархиальные ведомости. 1904. № 16. С. 440-444. 1904. № 17. С. 462-473.

Шадрин И. Г. Бурса: Повесть из современной жизни духовных семинарий и духовенства. Пг.: Тип. Л. Я. Гинзбурга, 1917. 368 с.

Шадрин И. Г. Памяти ректора Вологодской духовной семинарии протоиерея Иоанна Арсеньевича Лебедева. // Вологодские епархиальные ведомости. 1896. № 10. С. 181-184.

Шадрин И. Г. Сильнее смерти и другие рассказы. СПб.: Тип. Печ. труд, 1914. 263 c.

Шаламов Т., прот. Наши иерархи // Церковная заря. 1922. № 3. С. 5-7.

\section{Исследования}

Беляев В. И. Здравоохранение Ярославля в прошлом и настоящем. Ярославль: Ярославский мед. ин-т, 1961. 136 с.

Буриев Е. А. Книга жалкой мести // Миссионерское обозрение. 1914. № 1. C. 119-131.

Колодин Н. Н. Ярославские эскулапы: в 3 т. Ярославль: Канцлер, 2008-2009. Т. 1: Земцы. 2008. 374 с. 
Н. В. Солодов (Иерей Николай Солодов). Повесть И. Г. Шадрина «Бурса» ...

\section{References}

Beliaev, V. I. Zdravookhranenie Iaroslavlia v proshlom i nastoiashchem [Health Care of Yaroslavl in Past and Present]. Iaroslavl', Iaroslavskii meditsinskii institut Publ., 1961. 136 p. (In Russ.)

Burtsev, E. A. "Kniga zhalkoi mesti” ["The Book of Pathetic Revenge”]. Missionerskoe obozrenie, no. 1, 1914, pp. 119-131. (In Russ.)

Kolodin, N. N. Iaroslavskie eskulapy: $v 3$ t. [Yaroslavl Aesculapians: in 3 vols.], vol. 1. Iaroslavl', Kantsler Publ., 2008, 374 p. (In Russ.) 


\title{
Сотрудничество двух Институтов в изучении гуманитарных взаимосвязей народов Союзного государства в XIX и XX вв.
}

\begin{abstract}
Аннотация: В интервью журналу «Два века русской классики» директор филиала «Институт литературоведения имени Янки Купалы» Центра исследований белорусской культуры, языка и литературы Национальной академии наук Беларуси Иван Васильевич Саверченко рассказывает о продолжающемся с 2015 г. сотрудничестве с ИМЛИ РАН, связанном с исследованием литературных и культурных взаимосвязей русских и белорусов в XIX и XX вв. И. В. Саверченко объясняет уникальность проекта, который на основе впервые вводимых в научный оборот архивных и редких материалов дает возможность воссоздать всю историческую панораму национальных взаимосвязей в ее подлинном виде. В интервью сообщается об исследованных учеными фондах и архивах, об уникальных документах, найденных в процессе работы, о личностях писателей, культурных и общественных деятелей, работа которых имела огромное значение для творческого взаимодействия русского и белорусского народов. Особое внимание уделяется представлению совместных коллективных монографий, научных статей по материалам исследований, международных научных форумов, конференций, круглых столов и научно-практических семинаров.
\end{abstract}

Ключевье слова: Россия, Белоруссия, российско-белорусские отношения, сотрудничество, гуманитарные взаимосвязи, литература, культурные взаимодействия, история, архивы, публикации.

Информация об авторе: Иван Васильевич Саверченко, доктор филологических наук, профессор, директор филиала «Институт литературоведения имени Янки Купалы» Центра исследований белорусской культуры, языка и литературы, Национальная академия наук Беларуси просп. Независимости, д. 66, 220072 г. Минск, Республика Беларусь.

E-mail: ivasav_62@mail.ru

Дата поступления статьи в редакиию: 30.06 .2021

Дата одобрения статьи рецензентами: 28.07.2021

Дата публикации статьи: 30.09.2021

Для изитирования: Саверченко И. В. Сотрудничество двух Институтов в изучении гуманитарных взаимосвязей народов Союзного государства в XIX и XX вв. // Два века русской классики. 2021. Т. 3, № 3. С. 190-205. https://doi.org/10.22455/26867494-2021-3-3-190-205 


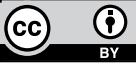

This is an open access article distributed under the Creative Commons Attribution 4.0 International (CC BY 4.0)
Dva veka russkoi klassiki, vol. 3, no. 3, 2021, pp. 190-205. ISSN 2686-7494

Two centuries of the Russian classics, vol. 3, no. 3, 2021, pp. 190-205. ISSN 2686-7494

Interview

(C) 2021. Ivan V. Saverchenko

National Academy of Sciences of Belarus,

Minsk, Belarus

\title{
Cooperation of Two Institutes in the Study of Humanitarian Relations of the Peoples of the Union State in the $19^{\text {th }}$ and $20^{\text {th }}$ Centuries
}

\begin{abstract}
In an interview with the magazine "Two centuries of the Russian classics" director of the branch of the Institute of Literary Criticism of Janka Kupala of the Center for the Study of Belarusian Culture, Language and Literature of National Academy of Sciences of Belarus Ivan Vasilyevich Saverchenko talks about the ongoing cooperation of his Institute with the IWL RAS since 2015, connected with the study of literary and cultural relationships between Russians and Belarusians in the $19^{\text {th }}$ and $20^{\text {th }}$ centuries. Ivan Saverchenko shows the uniqueness of the project, which, on the basis of archival and rare materials introduced into scientific circulation for the first time, makes it possible to recreate the entire historical panorama of national interconnections in its original form. In the interview, it is reported about the funds and archives investigated by scientists, about unique documents found in the process of work, about the personalities of writers, cultural and public figures, whose work was of great importance for the creative interaction of Russian and Belarusian peoples. Particular attention is paid to the presentation of joint collective monographs, scientific articles based on research materials, international scientific forums, conferences, round tables and scientific and practical seminars.

Keywords: Russia, Belarus, Russian-Belarusian relations, cooperation, humanitarian relations, literature, cultural interactions, history, archives, publications.
\end{abstract}

Information about the author: Ivan V. Saverchenko, DSc in Philology, Professor, Institute of Literary Criticism of Janka Kupala of National Academy of Sciences of Belarus, Nezavisimost Av., 66, 220072 Minsk, Belarus.

E-mail: ivasav_62@mail.ru

Received: June 30, 2021

Approved after reviewing: July 28, 2021

Published: September 30, 2021

For citation: Saverchenko, I. V. "Cooperation of Two Institutes in the Study of Humanitarian Relations of the Peoples of the Union State in the $19^{\text {th }}$ and $20^{\text {th }}$ Centuries." Dva veka russkoi klassiki, vol. 3, no. 3, 2021, pp. 190-205. (In Russ.) https://doi. org/10.22455/2686-7494-2021-3-3-190-205 
Здравствуйте, уважаемый Иван Васильевич! Большое спасибо, что нашли время ответить на некоторые вопросы, которые позволят показать нашим читателям важнейшие основы научного и культурного сотрудничества авторских коллективов Института мировой литературы им. А. М. Горького Российской академии наук и Института литературоведения им. Янки Купаль Центра исследований белорусской культуры, языка и литературь НАН Беларуси.

Добрый день! Я рад возможности рассказать о нашем проекте и дать интервью журналу ИМЛИ РАН, так как данное сотрудничество, как показала наша совместная работа за прошедшие 5-6 лет, очень продуктивно и перспективно. Оно позволило обнародовать множество новых интересных документов, о которых не было известно не только широкой общественности, но и ученым, рассказать о замечательных людях, внесших огромный вклад в литературное и культурное развитие и взаимодействие России и Белоруссии.

Когда приблизительно была начата и в чем в широком плане заключается работа в рамках обозначенного сотрудничества?

Взаимодействие наших Институтов началось в плане работы над текущим направлением в 2015 г. За это время создан целый цикл научно-исследовательских работ по теме «Гуманитарные взаимосвязи народов Союзного государства в XIX и XX вв.». Были подготовлены и выпущены совместные коллективные монографии, научные статьи по материалам исследований, проведены международные научные форумы и конференции, круглые столы и научно-практические семинары.

Фундаментальная научная проблема, на решение которой направлен цикл работ, заключается в расширении, обновлении и актуализации современных научных знаний о российско-белорусских отношениях в XIX-XX вв.: комплексном обследовании российских и белорусских архивов, выявлении не учтенных ранее источников и материалов по теме, в подготовке к научной публикации обнаруженных 
И. В. Саверченко. Сотрудничество двух Институтов в изучении гуманитарных ...

документов и введении их в научный оборот. В новаторском по своей сути научном исследовании такие литературные источники, как дневники, воспоминания и переписка классиков литературы и известных деятелей культуры, рассматриваются как отражение культурной жизни Белоруссии XIX-XX вв., ее связи с Россией.

Актуальность проекта заключается в том, что исследование российско-белорусских литературных и культурных связей на основе первоисточников, впервые вводимых в научный оборот архивных и редких материалов, проведение их научного анализа дают возможность воссоздать всю историческую панораму национальных взаимосвязей в ее подлинном, неискаженном виде.

Мь должнь спросить о государственной поддержке этого проекта или частей большого комплекса исследований, так как знаем, что и наши фондь, и белорусские фонды не остались равнодушньми и поддержали начинания и проводимую работу.

Да, действительно, Российский фонд фундаментальных исследований (проект № 18-512-00004 Бел_а) и Белорусский фонд фундаментальных исследований (проект № Г18Р-047) поддержали научно-исследовательскую работу «Белорусская земля в документах и воспоминаниях XIX-XX вв. По материалам российских и белорусских архивов». В рамках этой научно-исследовательской работы были изданы совместные коллективные труды: «Белорусская земля в воспоминаниях и документах XIX-XX вв.»: в 2018 и 2019 гг. вышли два выпуска.

При содействии Постоянного Комитета Союзного государства были изданы подготовленные в ИМЛИ РАН в рамках международного проекта следующие труды: «Настоящий друг русских классиков. И. Репин, Л. Толстой, И. Айвазовский и другие современники в дневниках и письмах Александра Жиркевича»; «Максимов С. В. Очерки о Белорусской земле», «М. Горький и А. Богданович: дружба, рожденная на берегах Волги. Переписка. Воспоминания. Архивные публикации. Исследования».

Уважаемьй Иван Васильевич, расскажите, пожалуйста, об ученьх, занимающихся этим проектом.

Со стороны ИМЛИ РАН прежде всего хочу сказать о главном редакторе Вашего журнала, большом ученом и замечательном человеке Марине Ивановне Щербаковой - докторе филологических наук, профессоре, заведующей Отделом русской классической литературы 
ИМЛИ РАН. Помощь, ценные указания, работа Марины Ивановны в этом проекте сразу определили его общее направление, глубокий смысл, можно сказать, «дали ему жизнь». Значительная редакторская и составительская, научная и организационная работа была проделана заместителем директора по научной работе ИМЛИ РАН Дарьей Сергеевной Московской, доктором филологических наук, главным научным сотрудником, заведующей отделом рукописей ИМЛИ РАН.

Со стороны Института литературоведения им. Янки Купалы Национальной академии наук Беларуси основными исполнителями стали Ваш покорный слуга, Иван Васильевич Саверченко, и моя коллега, талантливый литературовед Наталья Васильевна Яковенко, кандидат филологических наук, старший научный сотрудник отдела взаимосвязей литератур Института литературоведения им. Янки Купалы. Наталья Васильевна Яковенко, кстати, опубликовала в этом году в Вашем издании интересную рецензию на один из самых востребованных нынче патриотических учебников по русской литературе [Яковенко]. Как член редколлегии журнала «Два века русской классики», я слежу за выходом всех номеров.

В целом хочу отметить, что научное сотрудничество российских и белорусских ученых, наше скоординированное движение архивных изысканий - это те уникальные условия, при которых в полной мере реализован богатый потенциал настоящего проекта.

Скажите, пожалуйста, несколько слов о России и Белоруссии, об уходящем в века взаимодействии наших родственных народов и роли его для данного проекта.

В настоящем международном коллективном проекте серьезно и масштабно поставлена проблема взаимосвязей народов Союзного государства на протяжении двух веков, мы говорим о ХІХ и XX вв. Вспоминается и название Вашего журнала: «Два века русской классики», только у Вас в издании исследования касаются русской классической литературы XVIII и XIX вв. Но сразу же хочу отметить, что и наши разыскания шире. Историческая амплитуда авторитета России в западном регионе на протяжении XVIII-XX вв. не однажды колебалась от славных побед в наполеоновских войнах до попыток ее полного вытеснения с исторической арены. Российско-белорусские связи в их историческом контексте - тема принципиально неисчерпаемая, она может обновляться в результате архивных изысканий, обследования новых 
И. В. Саверченко. Сотрудничество двух Институтов в изучении гуманитарных ...

фондов, изучения новых источников. Историческая судьба Белорусской земли на протяжении веков во многом определялась ее геополитическим положением. Она оставалась местом встречи, столкновения и взаимодействия восточного и западнославянского, православного и католического миров. Многонациональный, многоконфессиональный и политически нестабильный регион неизменно оказывался ареной многих исторических катаклизмов. При этом столь же неизменными оставались роль России в жизни Северо-Западного края, в его государственном, экономическом и культурном развитии, влияние России на формирование духовной составляющей в развитии белорусского этноса.

Уважаемый Иван Васильевич, Вы много говорите об архивных источниках, новых материалах. Расскажите, пожалуйста, в каких архивах велась и ведется сейчас работа, связанная с проектом?

Исследовательская работа ведется в Российском государственном архиве литературы и искусства (РГАЛИ), Российском государственном историческом архиве (РГИА), Российском государственном военно-историческом архиве (РГВИА), Отделе рукописей Института мировой литературы им. А. М. Горького Российской академии наук (ОР ИМЛИ РАН), Рукописном отделе Института русской литературы (Пушкинский дом) Российской академии наук (РО ИРЛИ РАН), Отделе рукописей Российской национальной библиотеки (ОР РНБ), Отделе рукописей Российской государственной библиотеки (ОР РГБ), Архиве А. М. Горького Института мировой литературы им. А. М. Горького Российской академии наук (ОР ИМЛИ РАН), фонде А. В. Жиркевича в Отделе рукописей Государственного музея Л. Н. Толстого в Москве (ГМТ), в семейном архиве Жиркевичей (частное собрание), Государственном музее истории белорусской литературы (ГМИБЛ), Белорусском государственном архиве-музее литературы и искусства (БГАМЛИ), Центральной научной библиотеке им. Якуба Коласа НАН Беларуси (ЦНБ НАН), в фондах Витебского областного краеведческого музея (ВОКМ) и др. Многие фонды вышеназванных архивохранилищ прежде были изучены фрагментарно; это обеспечивает реальную возможность ценных находок, новых документальных источников и материалов.

К примеру, нами введены в научный оборот такие уникальные документы, как мемуары первого (после раздела в 1802 г. Белорусской губернии на Витебскую и Могилевскую) гражданского губернатора Витебска 
Сергея Алексеевича Шишкина (1802-1808) «Жизнь С. А. Шишкина». Хранящаяся в Отделе рукописей Российской национальной библиотеки тетрадь содержит многие подробности служебной и личной жизни мемуариста, которому Витебск обязан переломным периодом своей истории, превратившим город с течением времени в крупный административный, экономический и культурный центр.

Думаю, нашим читателям будет интересно усльшать о нескольких ярких литературных и общественных деятелях, работы которых Вами изучены.

Конечно, расскажу о нескольких самых значимых фигурах. Нами предпринят фронтальный аналитический просмотр одной из самых значительных в собрании Государственного музея Толстого (ГМТ) коллекций - фонда Александра Владимировича Жиркевича и семейного архива Жиркевичей. Внук витебского губернатора был военным юристом, общественным деятелем, литератором и вдающимся коллекционером конца XIX - начала XX вв. О масштабах фонда А. В. Жиркевича в ГМТ, о его научном исследовательском потенциале свидетельствуют цифры: объем дневников А. В. Жиркевича за 1880-1925 гг. составляют 12,5 тыс. рукописных листов; 4500 писем от 552 респондентов, 14 альбомов с автографами и собрание уникальных фотографий, включающее 592 снимка. В рамках проекта уже опубликованы дневники А. В. Жиркевича 18801881 гг., периода службы в Виленской губернии, документы судебной практики и деятельной борьбы за улучшение быта военных арестантов, переписка с военным министром России Д. А. Милютиным, мемуарный очерк о создании в Вильне музея М. Н. Муравьева. Как творческая личность, А. В. Жиркевич был хорошо знаком со многими деятелями искусства. В опубликованных архивных документах представлены материалы о его знакомстве с И. Е. Репиным и поездке в витебское имение художника Здравнёво. Атмосфера усадебной жизни Северо-Западного края передана в коллекции отроческих писем (также впервые опубликованных) будущей жены А. В. Жиркевича - Екатерины Снитко и ее брата-близнеца Андрея Константиновича Снитко, впоследствии видного белорусского археографа, археолога, этнографа, краеведа и музыковеда, одного из организаторов Минского церковного историко-археологического комитета, Минского церковно-археологического музея.

«Записки» (два тома in folio) Ивана Степановича Жиркевича - губернатора Витебска в 1836-1838 гг., участника наполеоновских войн, 
адъютанта А. А. Аракчеева, корреспондента А. П. Ермолова и Д. С. Блудова - выявлены в петербургском Архиве Военно-исторического музея артиллерии, инженерных войск и войск связи ${ }^{1}$. Хотя «Записки» И. С. Жиркевича публиковались в «Русской старине» (1874-1876, 1878, $1890)$ и в «Историческом вестнике» (1892), для подготовки научного издания необходим источник, рукописный оригинал текста; а его следы затерялись в XX в. Теперь архивная находка дает возможность ставить вопрос о научном издании памятника, страницы которого посвящены важным событиям истории Белорусской земли: Отечественной войне 1812 г., присоединению униатства к Православию. Не менее ценны запечатленные мемуаристом портреты исторических лиц: Николая I, А. А. Аракчеева, А. Х. Бенкендорфа, епископов Иосифа (Семашко) и Смарагда (Крыжановского), министра Д. Н. Блудова, обер-прокурора Н. А. Протасова и др.

С Белорусской землей связано имя Федора Федоровича Торнау (1810-1890), уроженца Полоцка, русского офицера, разведчика, дипломата, писателя. Его мемуарно-биографические и художественно-исторические очерки публиковались, начиная с 1850-х гг., в русских периодических и книжных изданиях. К ним примыкают незавершенные, изданные посмертно «Воспоминания», а также сохранившаяся в ОР РГБ в фонде Генерального Штаба солидная коллекция писем писателя, адресованных в период с 1844 по 1872 гг. Д. А. Милютину - выдающемуся военному историку и теоретику, военному министру России (1861-1881), генерал-фельдмаршалу. Закончив службу в чине генерал-лейтенанта, военным агентом России в Вене, членом Военно-ученого комитета Главного штаба, Ф. Ф. Торнау за свою жизнь участвовал в нескольких военных кампаниях, был причастен к подготовке и осуществлению стратегически важных операций, выполнял серьезные дипломатические и разведывательные поручения. Богатейшие впечатления неординарной судьбы нашли отражение в наследии писателя, объединившем и мемуары, и эпистолярий. В мемуарах Ф. Ф. Торнау талантливо воссоздана ретроспектива истории, в письмах - еe живое дыхание. Документы фонда Генерального Штаба (ОР РГБ) дают толчок составлению биографических очерков участников военных кампаний на Белорусской земле в первой половине XIX в., которые расширят све-

${ }^{1}$ ВИМАИВиВС. Ф. 51. Оп. 96/5. Д. 1 и 2. 298, 288 л. 
дения о защитниках Белорусской земли в XIX в., в частности, об участниках Отечественной войны 1812 г. Только по мемуарам Ф. Ф. Торнау выявлено более 150 имен и собраны сведения о них.

Отдельно нужно сказать о Сергее Васильевиче Максимове (18311901). Серьезному изучению Западного края способствовал в 1862 г. доклад министра народного просвещения А. В. Головнина. Согласно разработанной программе, требовалось исследовать племенные различия народностей, их численное соотношение, распределение по вероисповеданиям и степеням культуры, хозяйственный быт и уровень материального благосостояния. Область наблюдений охватывала девять губерний: Витебскую, Могилевскую, Минскую, Виленскую, Ковенскую, Гродненскую, Киевскую, Волынскую и Подольскую. Выполнение программы исследований было поручено А. Ф. Гильфердингу (этнографические исследования), М. О. Кояловичу (изучение религиозного быта), А. Б. фон Бушену (статистика и хозяйство). Однако в связи с политическими событиями 1863 г. экспедиция была отложена. В 1867 г., когда вновь встал вопрос о необходимости изучить Западный край, назначенные ранее исполнители от экспедиции отказались. Их обязанности взяли на себя бывший секретарь Могилевского статистического комитета Н. Я. Дубенский (статистико-экономические исследования) и писатель-этнограф С. В. Максимов (этнографическое изучение белорусов). Экспедиция была организована Русским Географическим обществом. Максимов в Белоруссии провел зимние месяцы 1867-1868 гг. Его задача заключалась в определении племенной границы белорусов и сопоставительной характеристике этнографических типов белоруса, великоросса и малоросса. Писатель объездил губернии Псковскую, Смоленскую, Могилевскую, Витебскую, Виленскую, Гродненскую, Минскую. Заказанный материал о белорусах был собран; частично он вошел в доклад писателя на заседании Русского Географического общества в ноябре 1869 г. С середины 1870-х гг. в периодической печати начали появляться его очерки «Из Белоруссии», «Из очерков Белоруссии», «Из картин прежнего народного быта», «Из белорусского быта»; готовилась эпическая книга о русском странничестве - «Бродячая Русь Христа-ради».

Документы, относящиеся к наследию писателя, выявлены в восьми архивах России, в 28 личных фондах. Это прямой путь к знаниям о реальных источниках и конкретном жизненном материале произведе- 
ний С. В. Максимова о Белорусской земле, об их творческой истории. Основная часть архивных находок вошла в изданную при содействии Постоянного Комитета Союзного государства книгу «Максимов С. В. Очерки о Белорусской земле».

В Витебском областном краеведческом музее проведена работа с архивом Алексея Парфеновича Сапунова, автора трудов по истории и археологии Беларуси, крупного исследователя и общественного деятеля рубежа XIX и XX вв. Из 643 единиц хранения Фонда Сапунова 97 составляет переписка. Изучение этого эпистолярного блока показало, что дальнейший поиск писем А. П. Сапунова в архивах его корреспондентов, в частности из России, обладает несомненным научным потенциалом. В изданиях цикла работ «Гуманитарные взаимосвязи народов Союзного государства в XIX и XX веках» предпринята научная публикация сохранившейся переписки белорусского ученого с петербургским корреспондентом В. Г. Дружининым (1859-1936) - историком, археографом, исследователем старообрядчества, собирателем древнерусских и старообрядческих рукописей и икон. Впервые введенные в научный оборот материалы вносят важные коррективы в утвердившиеся данные: уточняют хронологию источников, их текст, содержат аналитические суждения о ходе научных исследований в гуманитарной области. Еще один комплекс материалов из витебского фонда А. П. Сапунова связан с именем А. Я. Бодренка. Благодаря совместной публикации белорусских и российских ученых в научный оборот введены новые письма А. П. Сапунова и два ценных документа: «Приложение к очерку В. К. Стукалича о 25-летии ученой и литературной деятельности Алексея Парфеновича Сапунова» и «Воспоминания Алексея Яковлевича Бодренка 1883-1886 гг. и 1910-1916 гг.».

К 150-летию А. М. Горького была издана книга: «М. Горький и А. Богданович: дружба, рожденная на берегах Волги. Переписка. Воспоминания. Архивные публикации. Исследования». В ней можно найти воспоминания и переписку А. Богдановича с А. Горьким и членами его семьи, новые сведения, важные в рамках культурного взаимодействия России и Белоруссии. Это уникальный по глубине и искренности взаимных и любовных чувств, исполненный жизненных перипетий художественный «роман в письмах», в разнообразных ракурсах раскрывающий быт и взаимоотношения двух выдающихся представителей духовной и культурной элиты XX в. В книге впервые публикуется 
автографическая книга стихов Максима Богдановича, выявленная в Архиве А. М. Горького Д. С. Московской.

На основе редких архивных материалов обрела свою творческую историю семейная хроника классика белорусской литературы Максима Горецкого (1893-1938) «Виленские воспоминания». Эта книга одного из самых популярных белорусских писателей, переводчика, литературоведа и активного деятеля белорусского национального движения начала XX в. - знаковое явление в истории белорусской литературы и трагический документ эпохи. Между тем, в отличие от романа-хроники на белорусском языке «Виленские коммунары», впервые опубликованного в 1963 г., «Виленские воспоминания», написанные по-русски, не публиковались; рукопись книги хранится в фондах М. Горецкого Центральной научной библиотеки им. Якуба Коласа НАН Беларуси и в фондах Института литературоведения им. Янки Купалы ЦИБКЯЛ НАН Беларуси. Совместными усилиями положено начало изучению литературного памятника, истории его текста, что является основой для будущего научного издания. Белорусским участникам проекта удалось установить, что «Виленские воспоминания» - не перевод «Виленских коммунаров», а новое по своей сути документальное произведение. Автоцензурные изъятия, сделанные Горецким, свидетельствуют о жестких условиях политической ссылки, о гнетущем ощущении угрозы ареста и расстрела, которые вскоре и последовали.

Белорусскими исполнителями представленного цикла работ глубоко изучены материалы творческих биографий народных поэтов Я. Коласа, М. Танка, А. Кулешова, чей вклад в развитие национальной словесности определил вектор литературного процесса Белоруссии в $\mathrm{XX}$ в., их дружеских и творческих связей с российскими поэтами-переводчиками С. Городецким, Е. Мозольковым, М. Исаковским. В частности, при исследовании переписки Аркадия Кулешова с Михаилом Исаковским в фондах БГАМЛИ было изучено 119 документов, касающихся контактов этих поэтов. Совсем небольшая часть документов послужила материалом для книги белорусского текстолога Т. С. Голуб «Летопись жизни и творчества Аркадия Кулешова».

В целом белорусскими исполнителями выявлено 102 важных для литературоведения, краеведения, истории и культуры документа (письма, дневники, мемуары), установлен ряд значимых сведений о 
И. В. Саверченко. Сотрудничество двух Институтов в изучении гуманитарных ...

жизни и творчестве классиков белорусской литературы, культурных и общественных деятелей Витебского региона.

Несмотря на то что народь наши очень близки, что русский и белорусский языки родственнь и похожи, Вь и Ваши коллеги, наверное, немалое значение уделяете и проблеме коммуникатвных взаимодействий, переводов.

Да, конечно, полная разработка темы «Гуманитарные взаимосвязи народов Союзного государства в XIX и XX вв.» не была бы возможна без фундаментальных работ в русле художественного перевода, так как он является чрезвычайно важным средством литературной коммуникации и главной составляющей взаимопонимания и взаимовлияния литератур и культур. Этот вектор предусматривает как переводческую практику, так и научный анализ оригинальных и переводных произведений в контексте исследования белорусского национального этнического кода во взаимодействии с духовным и национальным самосознанием русского народа.

Мною впервые переведены на русский язык многие народные рассказы и наиболее значимые прозаические произведения белорусских писателей XIX - первой половины XX в., среди которых сочинения Я. Купалы, Я. Коласа, М. Богдановича, В. Голубка, В. Ластовского и М. Горецкого. Эти переводы опубликованы в книге «Ладья сокровищ: произведения белорусских писателей XIX - начала XX века», к которой я написал вступительную статью, постарался показать определяющее влияние русской классической литературы на становление и развитие белорусской словесности Нового времени.

В монографии Н. В. Яковенко «Художественный перевод с родственных языков в истории белорусской литературы» впервые в белорусской и русской переводоведческой науке концептуально систематизируется традиция перевода с родственных славянских языков, в первую очередь с белорусского и русского, с фокусировкой на литературном процессе Белоруссии. Материалом исследования, среди прочего, послужили оригиналы и переводы следующих произведений белорусских и русских авторов: «Апокриф» М. Богдановича, «Христос приземлился в Городне» В. Короткевича, «Знамя бригады» А. Кулешова, «Янук Селиба» М. Танка, «Иранский дневник» П. Панченко, «Мастер и Маргарита» М. Булгакова, «Событие» В. Набокова, «Разгром» А. Фадеева, «Они сражались за Родину» М. Шолохова, «Дни и ночи» К. Симонова. 
А где проходят основные научные мероприятия, собрания, конферениии, организуемье по исследуемой теме?

Конференции, форумы, семинары проводятся и в России, и в Белоруссии. Приведу в пример несколько знаковых мероприятий, чтобы Вы и читатели представили их масштаб: 1 декабря 2016 г. в Москве состоялся российско-белорусский форум «Горький - XXI век: А. М. Горький и мировой литературный процесс в контексте российско-белорусских связей», организованный Постоянным Комитетом Союзного государства, Международным информационным агентством «Россия сегодня» и Институтом мировой литературы им. А. М. Горького РАН; 14 июля 2017 г. в Витебске прошел круглый стол «Художественное и литературное наследие будущим поколениям» в рамках Дня Союзного государства на XXVI Международном фестивале искусств «Славянский базар в Витебске»; 22-23 ноября 2017 г. в Москве состоялся форум-семинар «Новый вектор гуманитарного партнерства в Союзном государстве», организованный Постоянным Комитетом Союзного государства и Международным информационным агентством «Россия сегодня»; 14-16 августа 2018 г. в Нижнем Новгороде и Ярославле был организован пресс-тур «Горький и Богданович: союз, рожденный на берегах Волги»; в Витебской области, в музее-усадьбе И. Е. Репина «Здравнево», 19 июля 2020 г. состоялся круглый стол «Диалог культур и литературы в Союзном государстве Беларуси и России».

Уважаемый Иван Васильевич, как Вы оцениваете уже состоявшееся, продолжающееся и будущее сотрудничество Института мировой литературь им. А. М. Горького и филиала Института литературоведения им. Янки Купаль Государственного научного учреждения «Центр исследований белорусской культуры, языка и литературы Национальной академии наук Беларуси»?

Научное сотрудничество белорусских и российских ученых, скоординированное движение их архивных изысканий - это те уникальные условия, при которых появилась возможность в полной мере реализовать богатый потенциал научно-исследовательских работ, объединенных общей темой «Гуманитарные взаимосвязи народов Союзного государства в XIX и XX веках». Убежден, что уже опубликованные результаты нашей работы очень значимы, показывают ее продуктивность. Мы продолжаем поиски ценных материалов и линий взаимодействия России и Белоруссии, думаю, что эта тема имеет множество 
И. В. Саверченко. Сотрудничество двух Институтов в изучении гуманитарных ...

перспектив, важна и в плане историческом, и для современной нашей жизни, для выстраивания дальнейшего тесного дружеского диалога не только ученых наших стран, но и наших народов, уже на протяжении нескольких веков объединенных глубинными культурными связями. 


\section{Список литературы \\ Исследования}

Белорусская земля в воспоминаниях и документах XIX-XX вв. / отв. ред. Д. С. Московская, М. И. Щербакова. М.: ИМЛИ РАН, 2018. Вып. 1. 448 с.

Белорусская земля в воспоминаниях и документах XIX-XX вв. / отв. ред. А. И. Алиева, М. И. Щербакова. М.: ИМЛИ РАН, 2019. Вып. 2. 336 с.

Ладья сокровищ: произведения белорусских писателей XIX - начала XX вв. / сост., предисл., коммент., пер. с бел. И. В. Саверченко. Минск: Беларусь, 2015. 319 с.

М. Горький и А. Богданович: дружба, рожденная на берегах Волги. Переписка. Воспоминания. Архивные публикации. Исследования / отв. ред. Д. С. Московская. М.: ООО «ИИА «Пресс-Меню», 2018. 648 с.

Максимов С. В. Очерки о Белорусской земле / научн. ред. М. И. Щербакова. М.: Индрик, 2018. 576 с.

Настоящий друг русских классиков. И. Репин, Л. Толстой, И. Айвазовский и другие современники в дневниках и письмах Александра Жиркевича / научн. ред. М. И. Щербакова; сост. Н. Г. Жиркевич-Подлесских, М. И. Щербакова. М.: ИИА «Пресс-Меню», 2017. 592 с.

Яковенко Н. В. Учебник, указующий путь к русской классике // Два века русской классики. 2021. Т. 3, № 1. С. 284-293. https://doi.org/10.22455/2686-7494-20213-1-284-293

Яковенко Н. В. Художественный перевод с родственных языков в истории белорусской литературы. Минск: Белорусская наука, 2019. 357 с. 


\section{References}

Moskovskaya, D. S., and M. I. Shcherbakova, editors. Belorusskaia zemlia v vospominaniiakh i dokumentakh XIX-XX vv. [Belarusian Land in Memoirs and Documents of the $19^{\text {th }}-20^{\text {th }}$ Centuries], issue 1. Moscow, IWL RAS Publ., 2018. 448 p. (In Russ.)

Alieva, A. I. and M. I. Shcherbakova, editors. Belorusskaia zemlia v vospominaniiakh $i$ dokumentakh XIX-XX vv. [Belarusian Land in Memoirs and Documents of the $19^{\text {th }}-20^{\text {th }}$ Centuries], issue 2. Moscow, IWL RAS Publ., 2019. 336 p. (In Russ.)

Lad'ia sokrovishch: proizvedeniia belorusskikh pisatelei 19 - nachala $20 \mathrm{vv}$. [A Boat of Treasures: Works of Belarusian Writers of the $19^{\text {th }}-$ Early $20^{\text {th }}$ Centuries], comp., introd., comm., transl. from Belarusian by I. V. Saverchenko. Minsk, Belarus' Publ., 2015. 319 p. (In Russ.)

Moskovskaya, D. S., editor. M. Gor'kii i A. Bogdanovich: druzhba, rozhdennaia na beregakh Volgi. Perepiska. Vospominaniia. Arkhivnye publikatsii. Issledovaniia [M. Gorky and A. Bogdanovich: Friendship Born on the Volga Banks. Correspondence. Memoirs. Archival Publications. Studies]. Moscow, IIA “Press-Meniu” Publ., 2018. 648 p. (In Russ.)

Maksimov, S. V. Ocherki o Belorusskoi zemle [Essays on the Belarusian Land], sci. ed. M. I. Shcherbakova. Moscow, Indrik Publ., 2018. 576 p. (In Russ.)

Shcherbakova, M. I., editor. Nastoiashchii drug russkikh klassikov. I. Repin, L. Tolstoi, I. Aivazovskii i drugie sovremenniki v dnevnikakh i pis'makh Aleksandra Zhirkevicha [A True Friend of Russian Classics. I. Repin, L. Tolstoy, I. Aivazovsky and Other Contemporaries in the Diaries and Letters of Alexander Zhirkevich], comp. by N. G. Zhirkevich-Podlesskikh, M. I. Shcherbakova. Moscow, IIA "Press-Meniu" Publ., 2017. 592 p. (In Russ.)

Iakovenko, N. V. "Uchebnik, ukazuiushchii put' k russkoi klassike" ["A Textbook Pointing the Way to the Russian Classics"]. Dva veka russkoi klassiki, vol. 3, no. 1, 2021, pp. 284-293. (In English) https://doi.org/10.22455/2686-7494-2021-3-1-284-293

Iakovenko, N. V. Khudozhestvennyi perevod s rodstvennykh iazykov v istorii belorusskoi literatury [Literary Translation from Related Languages in the History of Belarusian Literature]. Minsk, Belorusskaia nauka Publ., 2019. 357 p. (In Russ.) 
Алексей Константинович Толстой как открытие ${ }^{1}$

Аннотация: Рассматривается новая книга В. А. Котельникова «Алексей Константинович Толстой в жизни и в литературе». Автор рецензии перечисляет различные аспекты большого труда, ставшего открытием личности графа Алексея Константиновича Толстого (обстоятельств его жизни, отношений с современниками, мнений о насущных вопросах, философских размышлений и т. д.), открытием хранящего много загадок творчества А. К. Толстого, некоторых замечательных его современников, времени земного бытия писателя, жившего и творившего в сложную переходную историческую эпоху. Книга В. А. Котельникова примечательна открытием историко-культурной эпохи середины XIX в. в ее крупнейших свершениях и характерных тенденциях. Подчеркиваются широта кругозора и энциклопедические познания автора нового исследования, которые являются необходимым условием для создания книги о личности масштаба А. К. Толстого. Оценивается стиль нового издания, приведены основные содержательные аспекты, рассмотренные автором, показано значение труда для науки о литературе. Книга В. А. Котельникова через диалог, аналогии и сопоставления с творческой личностью писателя золотого века классики помогает современному читателю открыть самого себя.

Ключевье слова: А. К. Толстой, В. А. Котельников, русская классика, научные открытия, русские писатели, общественная жизнь, эпоха, биография, творчество, литературный контекст, Б. М. Маркевич.

Информаиия об авторе: Алексей Владимирович Федоров, доктор филологических наук, главный редактор издательства «Русское слово», Овчинниковская набережная, д. 20, стр. 2, 115035 г. Москва, Россия; учитель литературы школы № 1516, ул. Хабаровская, д. 4 а, 107589 г. Москва, Россия.

E-mail: fedorov@russlo.ru

Дата поступления статьи в редакцию: 11.05 .2021

Дата одобрения статьи рецензентами: 25.07 .2021

Дата публикации статьи: 30.09.2021

Для иитирования: Федоров А. В. Алексей Константинович Толстой как открытие (Рецензия на книгу: Котельников В. А. Алексей Константинович Толстой в жизни и в литературе. СПб.: Дмитрий Буланин, 2020. 864 с.) // Два века русской классики. 2021. T. 3, № 3. C. 206-217. https://doi.org/10.22455/2686-7494-2021-3-3-206-217

1 Рецензия на книгу: Котельников В. А. Алексей Константинович Толстой в жизни и в литературе. СПб.: Дмитрий Буланин, 2020. 864 с. 


\title{
А. В. Федоров. Алексей Константинович Толстой как открытие
}

\author{
Dva veka russkoi klassiki, \\ vol. 3, no. 3, 2021, pp. 206-217. ISSN 2686-7494 \\ Two centuries of the Russian classics, \\ Book Review
}

This is an open access article distributed under the Creative

Commons Attribution 4.0

International (CC BY 4.0)

\author{
(C) 2021. Alexey V. Fedorov \\ Russian Word publishing house \\ Moscow, Russia
}

\section{Alexey Konstantinovich Tolstoy as a Discovery ${ }^{1}$}

\begin{abstract}
In the review, V. A. Kotelnikov's new book "Alexei Konstantinovich Tolstoy in Life and Literature" is regarded as a scientific discovery. The author lists various aspects of the great work that became the discovery of the personality of Alexei Konstantinovich Tolstoy (the circumstances of his life, relations with contemporaries, opinions on pressing issues, philosophical reflections, etc.), the discovery of A. K. Tolstoy's works, keeping many mysteries, the discovery of some of his remarkable contemporaries, the discovery of the time of the earthly existence of the writer and poet who lived and worked in a difficult transitional historical era. The review notes that the book by V. A. Kotelnikov is remarkable for the discovery of the historical and cultural era of the middle of the $19^{\text {th }}$ century in her biggest achievements, characteristic tendencies. The author emphasizes the breadth and encyclopedic knowledge of the author of the new research, which is a necessary condition for creating a book about a personality of the scale of A. K. Tolstoy. The style of the new edition is assessed, the main substantive aspects considered by the author are given, the importance of labor in modern literary criticism is shown. The book by V. A. Kotelnikov through dialogue, analogies and comparisons with the creative personality of the writer of the golden age of the classics also becomes a discovery of himself for the modern reader.

Keywords: A. K. Tolstoy, V. A. Kotelnikov, Russian classics, scientific discoveries, Russian writers, social life, era, biography, creativity, literary context, B. M. Markevich.
\end{abstract}

Information about the author: Alexey V. Fedorov, DSc in Philology, Chief Editor of Russian Word publishing house, Ovchinnikovskaya Embankment 20, str. 2, 115035 Moscow, Russia, teacher of literature at school no. 1516, Khabarovskaya St., 4 a, 107589 Moscow, Russia.

E-mail: fedorov@russlo.ru

Received: May 11, 2021

Approved after reviewing: July 25, 2021

Published: September 30, 2021

For citation: Fedorov, A. V . "Alexey Konstantinovich Tolstoy as a Discovery (Book Review: Kotelnikov, V. A. Alexey Konstantinovich Tolstoy in Life and Literature. St. Petersburg, Dmitry Bulanin Publ., 2020. 864 p.)." Dva veka russkoi klassiki, vol. 3, no. 3, 2021, pp. 206-217. (In Russ.) https://doi.org/10.22455/2686-7494-2021-3-3-206-217

${ }^{1}$ Book Review: Kotelnikov, V. A. Alexey Konstantinovich Tolstoy in Life and Literature. St. Petersburg, Dmitry Bulanin Publ., 2020. 864 p. (In Russ.) 
Книгу Владимира Алексеевича Котельникова «Алексей Константинович Толстой в жизни и в литературе» можно назвать открытием.

Прежде всего, открытием этой удивительной личности - графа Алексея Константиновича Толстого. Обстоятельства его жизни, отношения с современниками, его мнения и суждения о насущных вопросах общественно-политической жизни и его философские размышления, его фантастический искрометный юмор и эстетические взгляды, бытовые привычки, увлечения, здоровье и болезни, характер, воспитание, стиль общения... - все это потрясающе интересно. Как ни странно, но у нас до сих пор не было серьезной, научно выверенной биографии этого классика отечественной литературы. Хотя сделано, конечно, было немало: можно назвать две книги в серии ЖЗЛ [Жуков; Новиков], дореволюционную обстоятельную (хотя и не переведенную на русский) монографию Анри Лиронделя [Lirondelle], нельзя забывать о многолетней работе И. Г. Ямпольского (собрания сочинений 1937, 1964, 1969, 2004 гг.) и других ученых.

И все-таки для нашего освоения творческого наследия А. К. Толстого ключевым можно считать 2017 г., когда отмечался 200-летний юбилей со дня рождения писателя. В связи с этим значимым поводом вышло в свет несколько изданий, в которых, можно сказать, заложены основы для дальнейшего развития современного изучения наследия А. К. Толстого. Особо хочется отметить двухтомник «Полное собрание стихотворений» в серии «Литературные памятники», вышедший в Санкт-Петербурге в 2016 г. и «Полное собрание сочинений и письма» в пяти томах, опубликованное в Москве в 2017-2018 гг. Оба собрания подготовлены научными коллективами под руководством В. А. Котельникова. Все тексты были сверены с первоисточниками, тексты на иностранных языках переведены заново, подробно раскрыты обстоятельства творческой истории произведений А. К. Толстого в связи с событиями его жизни. Богатейший материал - в основном архив- 
ный, собранный в процессе их подготовки, - вошел в комментарии и примечания, в обширные вступительные статьи. Тем не менее поместилось в собрание сочинений далеко не всё. Например, письма: в пятом томе собрания их почти 700 (при том, что самый полный свод, опубликованный в советское время, включал в себя около 300 [Толстой]). Но ведь писем А. К. Толстого, разбросанных по архивам разных городов и стран, обнаружено и научно обработано В. А. Котельниковым почти в три раза больше! И этот поистине бесценный источник еще ждет своей полной публикации (кстати, именно поэтому эпитет «полное» относится к собранию сочинений, а не к письмам). В книге «Алексей Константинович Толстой в жизни и в литературе» многие из писем приведены полностью или выборочно; они включены в контекст повествования о роде и семье писателя, о его вступлении в большую литературу, о путях его жизни и поэзии, о его любви, исторических штудиях, юморе, общении с современниками.

Все это помогает читателю открыть для себя личность графа Толстого. Она удивительна своей широтой, причем не в том смысле слова, о котором говорил Ф. М. Достоевский. Ее не хочется «сузить», потому что в нравственном отношении перед нами, судя по всему, абсолютно безупречный человек: светлый, тонкий, деликатный, сильный, щедрый и добрый. Широта связана с его кругозором, в котором увлечение русской стариной соседствовало с живейшим интересом к современности в ее общественно-политическом и культурном аспектах, а «поэзия деятельного вхождения в природу» (так изящно определяет В. А. Котельников смысл охоты для Толстого) [Котельников: 58] сочеталась с искренним влечением к спиритизму и другим «доказательствам» существования мира сверхъестественного [Котельников: 359-363]. Широта связана с разносторонностью его талантов и дарований, диапазоном его художнических настроений и обликов: от серьезных духовных переживаний до самозабвенной и озорной игры со всеми видами комического - под маской Козьмы Пруткова или безо всяких масок. Наконец, широта эта - способность к пониманию разных точек зрения на спорные и проклятые вопросы (не путать с толерантностью), умение сочувственно отозваться на иные голоса, вступать с ними в диалог - качество, в чем-то родственное пушкинской «всемирной отзывчивости».

В. А. Котельников не обходит молчанием сложные и спорные проблемы, неизбежно встающие перед любым биографом Толстого. Самая 
известная из таких проблем - причины внезапного расставания родителей будущего писателя. Различные версии, в том числе наиболее экстремальная - о том, что Константин Петрович Толстой не был отцом ребенка, - приводятся в книге с необходимым тактом и бережным отношением к семейной тайне, без каких-либо попыток «популяризировать» биографию через непроверенные факты [Котельников: 23-29]. В. А. Котельников стремится к объективной и взвешенной оценке личности К. П. Толстого, представленного во многих мемуарах предвзято, изображенного чуть ли не заурядным алкоголиком: «Появлявшиеся у некоторых мемуаристов и биографов упоминания о незначительности К. П. Толстого как личности, о неких его недостатках, возможно, проступках перед женой малодостоверны и, даже будь они правдой, вряд ли это в человеке вполне добропорядочном и неглупом могло стать главной причиной столь резкого разрыва» [Котельников: 24]. Еще одним проблемным вопросом, разделившим биографов А. К. Толстого фактически на два «лагеря», является та роль, которую сыграла в судьбе писателя его супруга - Софья Андреевна, урожденная Бахметева. В. А. Котельников подробно рассматривает зарождение и развитие романа А. К. Толстого с этой женщиной непростой судьбы и богатых дарований. Не допуская никакой идеализации отношений возлюбленных, а потом и супругов, ученый показывает, насколько ярко и драматично эти отношения проявлялись в лирике Толстого, какими интонациями окрашены чувства поэта в многочисленных письмах к своей Эгерии, как он ее сам называл. Тем не менее оставаться совершенно безучастным и холодно объективным при разговоре о Софье Андреевне, наверное, просто невозможно. Не резко, но вполне определенно В. А. Котельников высказывает свое мнение о ней: «Он хотел убедить ее обратиться к Богу и поверить, что его, Толстого, духовные силы через молитву дадут ей силы для жизни и радости, но этот призыв не нашел отклика у Софьи Андреевны, вполне равнодушной к подобным увещеваниям. Живая, а не только умственная религиозность вряд ли была ей свойственна; она предпочитала оставаться “вечно печальной” музой своего избранника, чьи мысли и убеждения, однако, мало в чем разделяла, ее больше привлекали либеральные идеи и положение эмансипированной женщины. Но и терять Толстого она не желала и впоследствии прекрасно освоилась с той ролью в обществе, которую получила в браке с ним» [Котельников: 329]. 
Рецензируемую книгу можно назвать открытием творчества Алексея Константиновича Толстого. В ней приведены ценные сведения об истории создания многих произведений писателя, об их восприятии современниками и о журнальных откликах, о редакциях и вариантах, что позволяет восстановить и зримо представить процесс работы над текстом. Крайне любопытна, например, история знаменитой баллады «Колокольчики мои...», которая существует, можно сказать, в двух обличиях - ранняя редакция представляет собой самостоятельное произведение, где звучит важное для исторического сознания писателя обещание: «Я прислушаюся к вам, / Цветики степные, / Русским людям передам / Я дела былые!» [Котельников: 90]. Во второй главе («Пути жизни, пути поэзии») помещена черновая правка наполненного пушкинскими реминисценциями стихотворения «Когда природа вся трепещет и сияет...» [Котельников: 122-126] и во многом итоговых, медитативно-программных стихотворений «Прозрачных облаков спокойное движенье...» и «Земля цвела. В лугу, весной одетом...» [Котельников: 295-309]. Исторические, литературные, биографические и другие источники, впечатления, факты, которые легли в основу сюжета того или иного произведения либо явились непосредственным стимулом к его созданию, также существенно проясняют наше представление о творчестве писателя. Малороссийская тематика многочисленных лирических высказываний А. К. Толстого, правнука последнего гетмана, играет одну из ведущих ролей в главе «Пути жизни, пути поэзии». В. А. Котельников, разбирая стихотворение «Ты знаешь край, где все обильем дышит...», точно подмечает, что "украинская музыка занимала очень значительное место в сфере его чувств, в его звуковой картине мира, влияла на мелофонию его поэтической речи...» [Котельников: 80]. Фольклорные истоки многих стихотворений и баллад поэта помогают ярче представить его личностные переживания жизненных, философских вопросов, словно подсказывают образы и ритмы, через которые веками в песенном творчестве выражалась народная душа [Котельников: 199-229]. Чуткость А. К. Толстого к чужому поэтическому слову, его восприимчивость и переимчивость определяют широкий спектр его художнических взаимодействий с отечественными писателями старших поколений - от Жуковского и Пушкина до 
Кольцова и Тютчева ${ }^{1}$. Уникальна и его способность перекладывать в стихи реальные тексты иных стилей и жанров, что ярко проявилось при работе над балладой «Василий Шибанов» (послание Курбского Грозному) и над поэмой «Иоанн Дамаскин» (погребальные стихиры). В. А. Котельников детально раскрывает степень поэтической вольности Толстого при обращении к Житию Иоанна Дамаскина, составленному Димитрием Ростовским [Котельников: 128-137].

Историческим произведениям писателя посвящена отдельная глава «История в лицах, картинах и сценах», где не только проанализированы баллады, поэмы, роман «Князь Серебряный» и драматические творения, в том числе «Посадник», но и осмыслена закономерность и естественность историзма художнического сознания писателя: «Из влечения к родовому и личному прошлому, что Толстой отчасти уже выразил в лирических формах, в 1840-е гг. стало вырастать стремление, осознаваемое постепенно как познавательная и творческая задача: узнать и художественно воссоздать события, лица, обстановку, язык прошедших эпох - так родился историзм Толстого, глубоко захвативший его воображение, мысль, речь и положивший на его стол массу материалов для литературной обработки» [Котельников: 397].

О ранней прозе Толстого широкому читателю известно мало. Тем любопытнее подробный анализ первой опубликованной повести «Упырь» в контексте традиций романтической фантастики и фольклорных славянских поверий, рассмотрение жизненных обстоятельств, повлиявших на сюжет произведения [Котельников: 44-50]. Особенно важен комментарий для понимания «темных», «зашифрованных» поэм «Алхимик» [Котельников: 275-286] и «Дракон» [Котельников: 291293], насыщенных многочисленными аллюзиями и реминисценциями. Незавершенная поэма «Алхимик» обращена к легендарной личности Раймонда Луллия, краткая биография которого с обзором его философско-религиозных воззрений помещена в книге В. А. Котельникова. Последнее крупное творение Толстого - поэма «Дракон» - стилизовано под перевод с итальянского подлинника XV в. Ученый скрупулезно восстанавливает факты военно-политического противостояния гвельфов и гибеллинов; предлагает свои варианты «исходных» лите-

${ }^{1}$ Ценным наблюдением представляются также параллели между некоторыми стихотворениями А. К. Толстого и В. В. Маяковского, весьма ценившего своего предшественника [Котельников: 589-590]. 
ратурных изображений дракона, которые могли стать стимулом для создания заглавного образа у Толстого.

Уже упомянутая широта кругозора писателя требует соответствующих широты и универсальности познаний от исследователя: книга В. А. Котельникова имеет поистине энциклопедический характер. Так, мы узнаем из нее не только о литературном творчестве А. К. Толстого, но и обо всем, что питало это творчество, что в нем отразилось и выразилось. А это огромный мир. Сам исследователь подчеркивает удивительную способность писателя соединять в своей творческой натуре на первый взгляд «вещи несовместные»: «Может показаться, что “горестная чаша", о которой Толстой писал в стихотворении “В совести искал я долго обвиненья...”, - едва ли не главный источник его жизнечувствования и творчества. Значительная часть его лирики... действительно проистекала из этого источника. Но в том и особенность натуры Толстого, что в ней бьет и другая сильная струя, ставшая источником игрового и смехового отношения к миру и смехотворчества. В первом источнике - вода судьбы поэта, во втором - вода свободы. Они текут в разных руслах и почти не сливаются» [Котельников: 547].

Отдельного внимания заслуживает переводческая деятельность писателя-полиглота, его поиски точных и красивых соответствий на родном языке: «Вообще все рукописные материалы к переводам Толстого показывают, как много усилий прилагал он к тому, чтобы создать безупречный поэтический эквивалент иноязычного текста» [Котельников: 251]. В качестве доказательства В. А. Котельников приводит материалы к переводу баллады И. В. Гёте «Коринфская невеста» [Котельников: 252-271]. Поражает требовательность переводчика к самому себе, количество вариантов и исправлений, упорство в стремлении достичь совершенства, полно передать «впечатление», которое поэт ценил выше буквального следования оригиналу. Получается, что открытие творчества А. К. Толстого неизбежно влечет за собой открытие мировой поэзии от Байрона и Гёте до Шенье и Гейне. «По родственным, общественным связям, по местопребываниям Толстой укоренен в русско-малороссийском этнокультурном мире. Но вместе с тем уже в детские годы благодаря влиянию А. А. Перовского установились и западные ориентиры Толстого. В эстетическом плане здесь главенствовало остававшееся неизменным влечение к Италии. В культурно-историческом и литературном первенствовала, несомненно, Германия» [Котельников: 240]. 
Безусловно, книга В. А. Котельникова - открытие некоторых по-своему замечательных современников Толстого, с которыми он в разные годы поддерживал отношения, проводил время, делился творческими планами и своими эстетическими предпочтениями, спорил на конкретные и отвлеченные темы, обсуждал новости и общих знакомых, шутил, мистифицировал, импровизировал... Братья Жемчужниковы, Н. И. Костомаров, И. С. Аксаков, А. А. Фет, И. А. Гончаров, И. С. Тургенев, Н. Ф. Крузе, Ф. И. Фиркс, О. А. Новикова, К. Сайн-Витгенштейн, Б. К. Мейендорф, М. Н. Катков, М. М. Стасюлевич - персонажи главы «Круг Толстого», куда вошел значительный корпус эпистолярия Алексея Константиновича. Часто о своих художественных поисках и находках он рассказывал близким людям в письмах, в частности, о трудной отделке «Князя Серебряного» и своих сомнениях относительно характера главного героя, о замысле и реализации Драматической трилогии, которую он собирался назвать именем Бориса Годунова, о проблематике и финале драматической поэмы «Дон Жуан», о «бессознательной» природе творчества, о точных и неточных рифмах и о многом другом.

Отдельная глава в книге В. А. Котельникова посвящена двум хорошим знакомым и многолетним адресатам писем Толстого - Болеславу Михайловичу Маркевичу и Каролине Карловне Павловой. С Маркевичем дружеское общение нередко выходило за рамки собственно литературной проблематики, затрагивая «политические, общественные, житейские» [Котельников: 644] и другие темы, в частности, спиритизм и сеансы Д. Юма [Котельников: 646-649], брахманизм и неизбежность страданий [Котельников: 685-689], национальную политику Российской империи в контексте событий польского восстания [Котельников: 658-660], «татарский период» отечественной истории и его следы в русском национальном характере [Котельников: 669-670], хозяйственные вопросы, связанные с постепенным разорением имений Толстого [Котельников: 674-676], наконец, здоровье, которое у Толстого с конца 1860-х гг. резко ухудшается. «И как никто другой, именно Маркевич понимает и принимает речевые изыски и словесные игры Толстого, в которые он то и дело пускается» [Котельников: 651]. Личность Б. М. Маркевича заслуживает внимания не только потому, что он выступал как корреспондент А. К. Толстого, он был также весьма заметным литературным деятелем той поры, романистом, полное собрание сочинений которого включает в себя 11 томов (СПб., 1885). Кстати сказать, более 
века ни одно из его произведений не переиздавалось - по понятным причинам (консерватор-монархист). Хочется верить, что теперь эти причины не должны мешать возвращению в наш культурный обиход этой интереснейшей личности.

Рецензируемый большой труд стал открытием времени А. К. Толстого, сложной переходной исторической эпохи, центральным событием которой явилась Крымская (Восточная) война и неизбежное (но не всегда органичное) изменение многих сторон общественной и политической жизни страны. Среди этих изменений нового царствования - важнейшие из Великих реформ: крестьянская, судебная, цензурная, образовательная. Ко всем из них у Алексея Константиновича было свое отношение, которое он не скрывал - прежде всего, в дружеской переписке. Но и в своем творчестве, несмотря на декларируемую отстраненность от «злобы дня», он нередко затрагивал самые животрепещущие вопросы, не имеющие, казалось бы, никакого отношения к искусству. Перипетии политических игр, приведших к началу Крымской кампании, отразились в издевательском стихотворении Толстого «Поразмыслив аккуратно...» [Котельников: 174-176], а трагические последствия войны зазвучали в лирических интонациях замечательного цикла «Крымские очерки» [Котельников: 179-192]. Под прицел его едкой и остроумной сатиры попадает нигилизм как многоликое явление в его мировоззренческом и политическом аспектах. Это явление воспринимается писателем как угроза - прежде всего, для искусства. Но ведь искусство непосредственно связано с духовной природой человека! Поэтому радикальный нигилизм античеловечен по сути своей. Об этом прозорливые стихотворения А. К. Толстого «Против течения» [Котельников: 143-145], «Пантелей-целитель» [Котельников: 612-615], «Порой веселой мая...» [Котельников: 146, 593598], «Поток-богатырь» [Котельников: 147, 598-611]. В. А. Котельников справедливо замечает, что «темперамент художника и идейного борца побуждал Толстого выходить за пределы “чистого искусства" и преследовать “отрицательное” направление в поэтических памфлетах» [Котельников: 146]. Свой сарказм по отношению к «неоправданно оправдательной» практике суда присяжных писатель выражает не только в балладе «Поток-богатырь», но и в комическом стихотворении «Рондо», обращенном к деятелю судебной реформы графу Константину Ивановичу Палену [Котельников: 601]. 
Книга В. А. Котельникова примечательна открытием историкокультурной эпохи середины XIX столетия в ее крупнейших свершениях, в ее характерных тенденциях в самых разных областях искусства, науки, публицистики. Мы узнаем о романтизме как мировосприятии и литературном направлении, о «натуральной школе», на которую Толстой отозвался в нескольких письмах и художественных произведениях [Котельников: 67-69], о славянофильстве и его представителях (А. С. Хомяков, И. С. и К. С. Аксаковы, А. И. Кошелев), с которыми Толстой общался и дружил, не уставая полемизировать как в письмах, так и в стихотворениях [Котельников: 92-96]; о консерватизме и проблеме русификации западных окраин Российской империи [Котельников: 619-623]; о «чистом искусстве» и его противостоянии с «гражданской» лирикой; о журналах, в которых печатался Толстой и в которых помещались отклики на его произведения («Отечественные записки», «Современник», «Русский вестник», «Вестник Европы» и др.) и о многом другом.

Наконец, рецензируемое издание может стать открытием самих себя - нас сегодняшних - через диалог, аналогии и сопоставления, неизбежно возникающие при знакомстве с творческой личностью писателя золотого века нашей классики. В этом главная особенность классической литературы: она всегда вовремя, всегда с нами и в то же время - на опережение, на вырост, чуть впереди, а не позади нас. Это возможность задать самим себе важнейшие вопросы. И самостоятельно найти ответы, определить свой путь - если понадобится, то и «против течения».

Граф Алексей Константинович Толстой - не застывший памятник, не пыльный музей, а окно: в сверкающий красками, многосложный и сияющий мир. Тот, кто пишет о нем, должен быть ему соприроден и сомасштабен. Это почти невозможно, но необходимо. Спасибо Владимиру Алексеевичу Котельникову, который помог это окно раскрыть для всех, кто хочет дышать чистым воздухом вечной красоты и поэзии. 


\section{А. В. Федоров. Алексей Константинович Толстой как открытие}

\section{Список литературы \\ Источники}

Толстой А. К. Собр. соч.: в 4 т. / вступ. ст., подгот. текста и примеч. И. Ямпольского. М.: Литиздат, 1963-1964.

Толстой А. К. Полн. собр. соч. и письма: в 5 т. М.: Классика, 2017-2018.

\section{Исследования}

Жуков Д. А. Алексей Константинович Толстой. М.: Мол. гвардия, 1982. 383 с.

Котельников В. А. Алексей Константинович Толстой в жизни и в литературе. СПб.: Дмитрий Буланин, 2020. 864 с.

Новиков В. И. Алексей Константинович Толстой. М.: Мол. гвардия, 2011. 288 с.

Lirondelle André. Le poète Alexis Tolstoï. L'homme et l'œuvre. Paris, Hachette, 1912. $677 \mathrm{p}$.

\section{References}

Zhukov, D. A. Aleksei Konstantinovich Tolstoi [Alexey Konstantinovich Tolstoy]. Moscow, Molodaia gvardiia Publ., 1982. 383 p. (In Russ.)

Kotel'nikov, V. A. Aleksei Konstantinovich Tolstoi $v$ zhizni i v literature [Alexey Konstantinovich Tolstoy in Life and Literature]. St. Petersburg, Dmitrii Bulanin Publ., 2020. 864 p. (In Russ.)

Novikov, V. I. Aleksei Konstantinovich Tolstoi [Alexey Konstantinovich Tolstoy]. Moscow, Molodaia gvardiia Publ., 2011. 288 p. (In Russ.)

Lirondelle, André. Le poète Alexis Tolstoï. L’homme et l'ouvre. Paris, Hachette, 1912. 677 p. (In French) 


\section{СЕТЕВОЕ ИЗДАНИЕ}

Научный журнал

Два века русской классики / Two centuries of the Russian classics
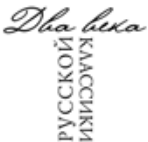

$2021-$ T. 3 - № 3

Учредитель и издатель

Институт мировой литературы им. А. М. Горького

Российской академии наук

Главный редактор

Щербакова Марина Ивановна

доктор филологических наук, профессор,

заведующая отделом русской классической литературы ИМЛИ РАН

\section{Дизайн обложки и макет журнала Компьютерная верстка}

Д. К. Бернштейн А. З. Бернштейн

\section{Корректор}

В. Г. Андреева

Журнал зарегистрирован

Федеральной службой по надзору в сфере связи, информационных технологий и массовых коммуникаций (Роскомнадзор) Свидетельство о регистрации: ПИ № Эл 77-76366 от 02.08.2019 г.

Адрес учредителя, редакции и издателя:

121069, Москва, ул. Поварская, 25a

Тел.: (495)690-50-30

E-mail: journal_ork@mail.ru

Сайт журнала: www.rusklassika.ru

Дата размещения сетевого издания в сети Интернет на официальном сайте http://rusklassika.ru 30.09.2021 г.

При перепечатке ссылка обязательна 

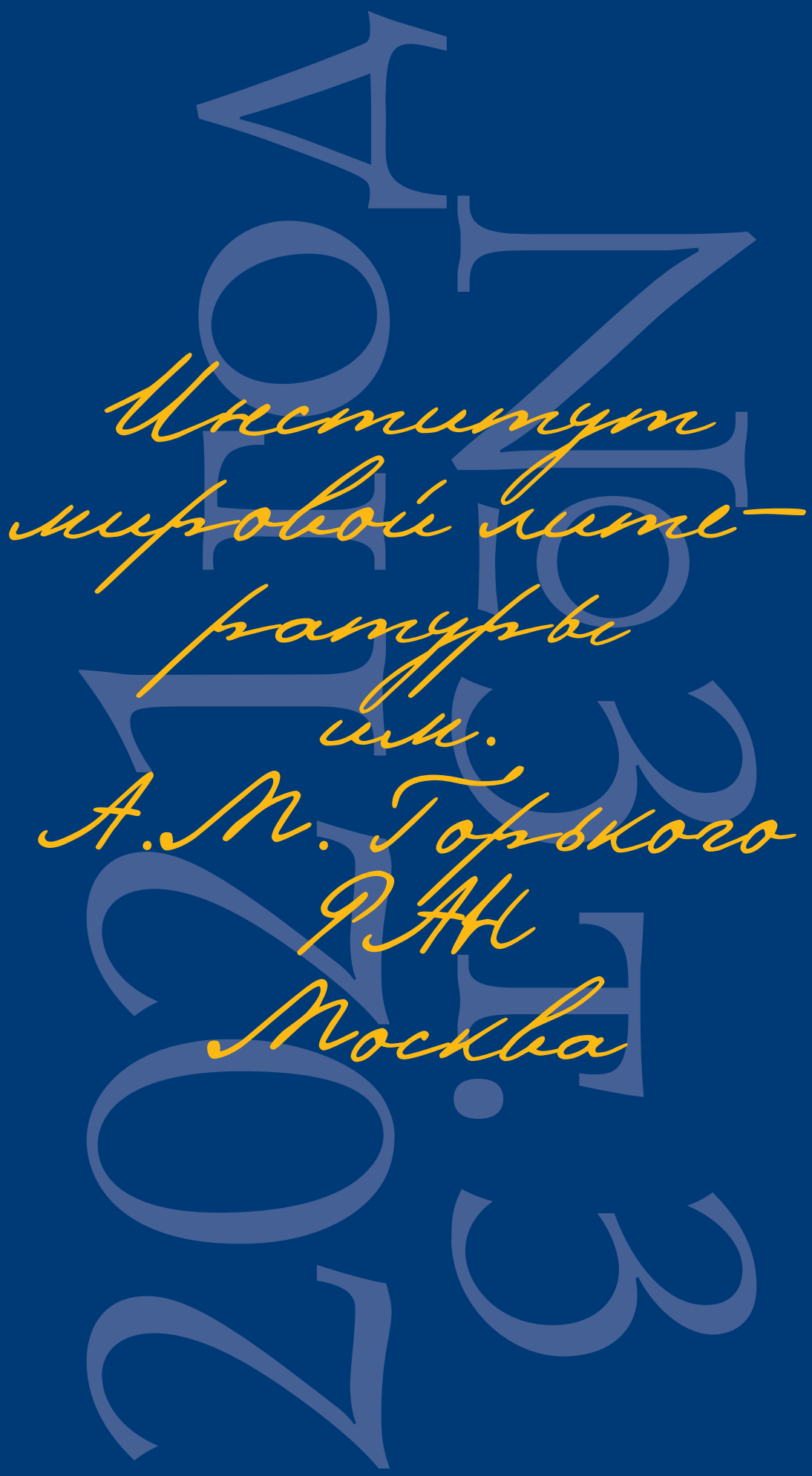